Total Petroleum Systems of the

Paleozoic and Jurassic, Greater Ghawar Uplift

and Adjoining Provinces of

Central Saudi Arabia and

Northern Arabian-Persian Gulf

U.S. Geological Survey Bulletin 2202-H 


\section{Total Petroleum Systems of the Paleozoic and Jurassic, Greater Ghawar Uplift and Adjoining Provinces of Central Saudi Arabia and Northern Arabian-Persian Gulf}

By Richard M. Pollastro

U.S. Geological Survey Bulletin 2202-H 


\section{U.S. Department of the Interior \\ Gale A. Norton, Secretary}

\section{U.S. Geological Survey \\ Charles G. Groat, Director}

Version 1.0, 2003

For more information about the USGS and its products:

Telephone: 1-888-ASK-USGS

World Wide Web: http://www.usgs.gov/

This publication is only available online at:

http://pubs.usgs.gov/bul/b2202-h/

Any use of trade, product, or firm names in this publication is for descriptive purposes only and does not imply endorsement by the U.S. Government. 


\section{Contents}

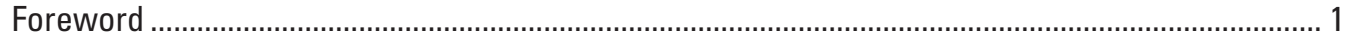

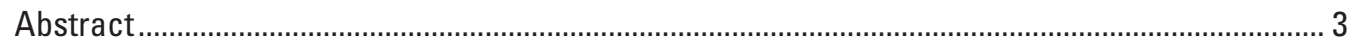

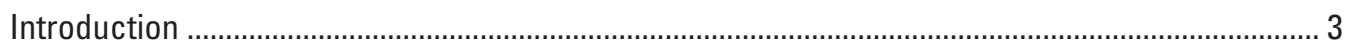

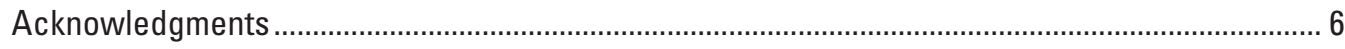

U.S. Geological Survey Geologic Provinces of Central Saudi Arabia and Gulf Area ..................... 6

Greater Petroleum Systems of the Eastern Arabian Peninsula ...................................................... 9

Tectonic Evolution and Structural Setting ................................................................................. 9

Stratigraphy of Central Saudi Arabia and Greater Ghawar Region ................................................. 18

Pre-Khuff Section ...................................................................................................... 18

Late Permian Through Jurassic .............................................................................. 20

Central Arabia Qusaiba-Paleozoic Total Petroleum System ......................................................... 24

General Description ................................................................................................ 24

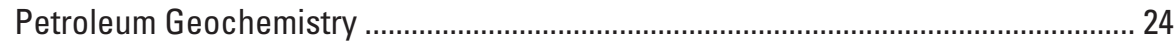

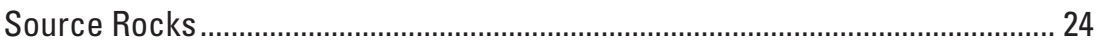

Organic Geochemistry........................................................................................ 29

Maturation, Generation, and Expulsion ........................................................... 29

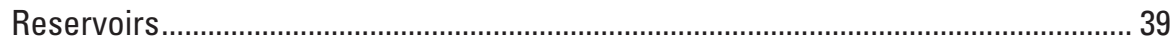

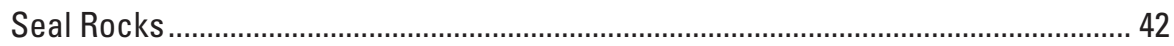

Traps and Trap Styles ..................................................................................................... 42

Arabian Sub-Basin Tuwaiq/Hanifa-Arab Total Petroleum System .............................................. 44

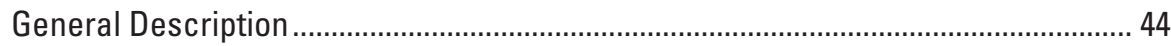

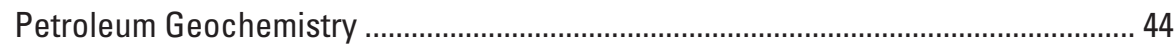

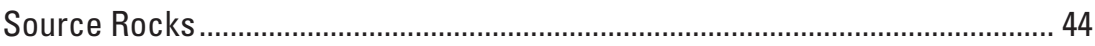

Organic Geochemistry................................................................................ 49

Maturation, Generation, and Expulsion .......................................................... 49

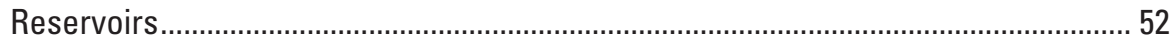

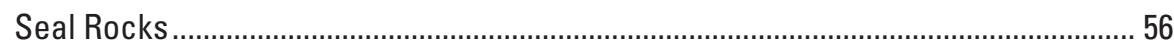

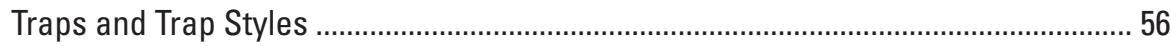

Assessment Unit Description, Geologic Models, and Assessment Results ................................. 57

Central Arabia Qusaiba-Paleozoic TPS .................................................................... 57

Central Arch Horst-Block Anticlinal Oil and Gas AU (20210101) ........................ 57

North Gulf Salt Basin Structural Gas AU (20210102) ......................................... 65

Arabian Sub-Basin Tuwaiq/Hanifa-Arab TPS ........................................................ 65

Horst-Block Anticlinal Oil AU (20210201)......................................................... 65

Salt-Involved Structural Oil AU (20210202) ....................................................... 68

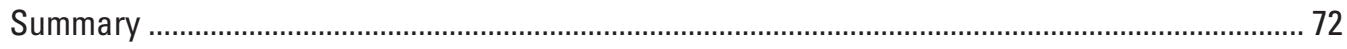

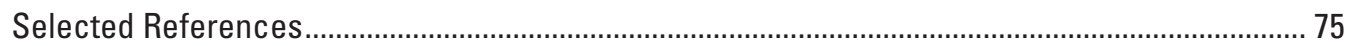

Appendix 1. Seventh Approximation Input Form for Central Arch Horst-Block Anticlinal Oil and Gas Assessment Unit (20210101), Central Arabia Qusaiba-Paleozoic

Total Petroleum System..................................................................................................... 81

Appendix 2. Seventh Approximation Input Form for North Gulf Salt Basin Structural Gas Assessment Unit (20210102), Central Arabia Qusaiba-Paleozoic Total Petroleum System 
Appendix 3. Seventh Approximation Input Form for Horst-Block Anticlinal

Oil Assessment Unit (20210201), Arabian Sub-Basin Tuwaiq/Hanifa-Arab

Total Petroleum System

Appendix 4. Seventh Approximation Input Form for Salt-Involved Structural Oil Assessment

Unit (20210202), Arabian Sub-Basin Tuwaiq/Hanifa-Arab Total Petroleum System. 96

\section{Figures}

1. Diagram showing stratigraphic section, major tectonic events, and stratigraphic units of petroleum systems of the eastern Arabian Peninsula.

2-7. Maps showing:

2. USGS geologic provinces of central Saudi Arabia and northern Arabian-Persian Gulf, and details of oil and gas fields and reservoirs.

3. Arabian Plate showing general tectonic and structural features, salt basins, and oil and gas fields.

4. Jurassic intraplatform sub-basins of Arabian-Persian Gulf region.

5. Paleozoic and Jurassic total petroleum systems of Gotnia sub-basin. 10

6. USGS geologic provinces, oil and gas field centerpoints, and total petroleum systems of central Saudi Arabia and northern Arabian-Persian Gulf..

7. Cretaceous, Jurassic, and Paleozoic total petroleum systems and oil and gas field centerpoints of Rub'al Khali Province (2019).

8. Sketch block diagrams showing evolution of Arabian Plate tectonics............................. 14

9. Geologic cross section across Saudi Arabia and Qatar............................................... 15

10. Geologic subcrop map of Hercynian or "Pre-Unayzah" unconformity ........................... 16

11. Structural cross section of central Ghawar field ......................................................... 17

12. Chart showing growth history of major tectonic events and relative intensities ........... 19

13. Diagram showing stratigraphic column and tectonostratigraphic events of the Paleozoic section in Greater Ghawar area ............................................................. 21

14. General stratigraphic section of the Upper Jurassic Arab Formation ............................ 23

15. Map showing Central Arabia Qusaiba-Paleozoic Total Petroleum System and assessment units

16. Paleoenvironmental map of the Early Silurian showing approximate extent of the Qusaiba Shale Member of the Qalibah Formation on Arabian Peninsula 26

17-19. Maps showing:

17. Central Arabia and Rub 'al Khali Basin showing details of oil and gas fields producing from the Paleozoic

18. Geographic extent and present-day zones of hydrocarbon generation for Silurian Qusaiba Shale Member

19. Mean field API gravities and general locations of oil and gas fields in central Saudi Arabia and northern Arabian-Persian Gulf producing from Pre-Khuff and Khuff or younger formations

20. Diagram showing relation between gamma-ray response and total organic carbon in transitional-type, basal hot shale of lower Qusaiba Member source rock ... 31

21. Events chart for Central Arabia Qusaiba-Paleozoic Total Petroleum System (202101) . 32

22. Diagram showing burial history and hydrocarbon generation model for base of Silurian Qusaiba source rock in Udaynan well ........................................................... 34

23. Diagrams modeling hydrocarbon expulsion history from Qusaiba source rock............. 35 
24. Diagram showing Khuff and Pre-Khuff section along basin monocline from Dilam field to Abu Jifan field. 36

25. Maps of central Arabia and Greater Ghawar area showing expulsion of oil and gas from Qusaiba hot shale. 37

26. Map showing Central Arabia Qusaiba-Paleozoic Total Petroleum System, active source rock, and oil and gas field centerpoints.

27. Paleogeographic map during the Early Permian, showing erosion or nondeposition, dune fields, probable glacial lake, and dominant wind direction in central Arabian Peninsula. 40

28. Isopach map of the Unayzah Formation in central Saudi Arabia 41

29. Generalized map describing the Khuff Formation in Arabian Peninsula and Zagros Fold Belt

30. Map showing Arabian Sub-Basin Tuwaiq/Hanifa-Arab Total Petroleum System, Horst-Block Anticlinal Oil Assessment Unit, and Salt-Involved Structural Oil Assessment Unit 45

31. Events chart for Arabian Sub-Basin Tuwaiq/Hanifa-Arab Total Petroleum System (202102)

32. Map showing oil and gas fields of the Arabian-Persian Gulf with reservoirs in Jurassic rocks 47

33. Paleogeographic map of Jurassic sub-basins of Arabian-Persian Gulf region 48

34. Isopach map of petroleum source-potential units of Upper Jurassic Tuwaiq Mountain Formation

35. Map summarizing present-day extent of thermal maturity levels and distribution of source facies for the Jurassic Hanifa Formation

36. Maps of central Saudi Arabia showing expulsion of oil from Jurassic source rocks ... 53

37. Diagram showing burial history and petroleum generation model for Tuwaiq/Hanifa source rocks near Safaniya field

38. Map showing paleoenvironment and tectonic reconstruction of the Late Jurassic, late Tithonian of Arabian Plate.

39. Map showing general structural trends of Greater Ghawar Uplift and surrounding area

40-46. Plots showing:

40. Known oil-field size and grown oil-field size versus field discovery year for Central Arch Horst-Block Anticlinal Oil and Gas Assessment Unit

41. Known gas-field size versus field discovery year and grown gas-field size versus cumulative number of new-field wildcat wells for Central Arch Horst- Block Anticlinal Oil and Gas Assessment Unit

42. New-field wildcat wells versus drilling completion year, cumulative number of oil fields versus field discovery year, and cumulative number of gas fields versus field discovery year for Central Arch Horst-Block Anticlinal Oil and Gas Assessment Unit

43. Known oil-field size and grown oil-field size versus field discovery year for Horst-Block Anticlinal Oil Assessment Unit.

44. New-field wildcat wells versus drilling completion year and cumulative number of new-field wildcat wells versus drilling completion year for Horst-Block Anticlinal Oil Assessment Unit

45. Known oil-field size versus field discovery year and grown oil-field size versus field discovery year for Salt-Involved Structural Oil Assessment Unit ..... 71

46. New-field wildcat wells versus drilling completion year and cumulative number of new-field wildcat wells versus drilling completion year for Salt-Involved Structural Oil Assessment Unit. 


\section{Tables}

1. Assessment summary for Central Arabia Qusaiba-Paleozoic Total Petroleum System (202101)

2. Known and grown volumes of discovered petroleum and discovery-history sequence for Central Arch Horst-Block Anticlinal Oil and Gas Assessment Unit (20210101)

3. Assessment summary results for Arabian Sub-Basin Tuwaiq/Hanifa-Arab Total Petroleum System (202102)

4. Known and grown discovered volumes of petroleum resources and discovery-history sequence for Horst-Block Anticlinal Oil Assessment Unit (20210201).

5. Known and grown discovered volumes and discovery-history sequence for Salt-Involved Structural Oil Assessment Unit (20210202) 


\title{
Total Petroleum Systems of the Paleozoic and Jurassic, Greater Ghawar Uplift and Adjoining Provinces of Central Saudi Arabia and Northern Arabian-Persian Gulf
}

\author{
By Richard M. Pollastro
}

\section{Foreword}

This report was prepared as part of the U.S. Geological Survey World Petroleum Assessment 2000. The primary objective of World Petroleum Assessment 2000 was to assess the quantities of conventional oil, gas, and natural gas liquids outside the United States that have the potential to be added to reserves in the next 30 years. Parts of these assessed volumes reside in undiscovered fields whose sizes exceed the stated minimum-field-size cutoff value for the assessment unit, which is variable but must be at least 1 million barrels of oil equivalent. Another part of these assessed volumes occurs as reserve growth of fields already discovered. However, the contribution from reserve growth of discovered fields to resources is not covered for the areas treated in this report.

In order to organize, evaluate, and delineate areas to assess, the authors of World Petroleum Assessment 2000 developed a hierarchical scheme of geographic and geologic units. This scheme consists of regions, geologic provinces, total petroleum systems, and assessment units. For World Petroleum Assessment 2000, regions serve as organizational units and geologic provinces are used as prioritization tools. Assessment of undiscovered resources was done at the level of the assessment unit.

The world was divided into 8 regions and 937 geologic provinces. These provinces have been ranked according to the discovered known oil and gas volumes (Klett and others, 1997). Then, 76 "priority" provinces (exclusive of the United States and chosen for their high ranking) and 26 "boutique" provinces (exclusive of the United States) were selected for appraisal of oil and gas resources. Boutique provinces were chosen for their anticipated petroleum richness or special regional economic or strategic importance.

A geologic province is an area having characteristic dimensions of hundreds of kilometers that encompasses a natural geologic entity (for example, a sedimentary basin, thrust belt, or accreted terrane) or some combination of contiguous geologic entities. Each geologic province is a spatial entity with common geologic attributes. Province boundaries were drawn as logically as possible along natural geologic boundaries, although in some places they were located arbitrarily (for example, along specific water-depth contours in the open oceans). Specifically, geologic provinces of the Arabian Peninsula are shown in Pollastro and others (1999).

Total petroleum systems and assessment units were delineated for each geologic province considered for assessment. The boundaries of total petroleum systems and assessment units need not be entirely contained within a geologic province. Particular emphasis is placed on the similarities of petroleum fluids within total petroleum systems, in contrast to geologic provinces and plays in which similarities of rocks are emphasized.

The total petroleum system includes all genetically related petroleum that occurs in shows and accumulations (discovered and undiscovered) generated by a pod or by closely related pods of mature source rock. Total petroleum systems exist within a limited mappable geologic space, together with the essential mappable geologic elements (source, reservoir, seal, and overburden rocks). These essential geologic elements control the fundamental processes of generation, expulsion, migration, entrapment, and preservation of petroleum within the total petroleum system.

An assessment unit is a mappable part of a total petroleum system in which discovered and undiscovered oil and gas fields constitute a single relatively homogeneous population such that the methodology of resource assessment based on estimation of the number and sizes of undiscovered fields is applicable. A total petroleum system might equate to a single assessment unit. If necessary, a total petroleum system may be subdivided into two or more assessment units such that each assessment unit is sufficiently homogeneous in terms of geology, exploration considerations, and risk to assess individually. Differences in the distributions of accumulation density, trap styles, reservoirs, and exploration concepts within an assessment unit were recognized and not assumed to extend homogeneously across an entire assessment unit.

A numeric code identifies each region, province, total petroleum system, and assessment unit. The criteria for assigning codes are uniform throughout the project and throughout all publications of the project. The numeric codes used in this study are: 


\begin{tabular}{llr}
\hline \multicolumn{1}{c}{ Unit } & \multicolumn{1}{c}{ Name } & Code \\
\hline Region & Middle East and North Africa & $\mathbf{2}$ \\
Province & Greater Ghawar Uplift & 2021 \\
Total Petroleum Systems & Central Arabia Qusaiba-Paleozoic & 202101 \\
& Arabian Sub-Basin Tuwaiq/Hanifa-Arab & 202102 \\
Assessment Units & Central Arch Horst-Block Anticlinal Oil and Gas & 20210101 \\
& North Gulf Salt Basin Structural Gas & 20210102 \\
& Horst-Block Anticlinal Oil & 20210201 \\
& Salt-Involved Structural Oil & 20210202
\end{tabular}

A graphical depiction that places the elements of the total petroleum system into the context of geologic time is provided in the form of an events chart. Items on the events chart include (1) the major rock-unit names; (2) the temporal extent of source-rock deposition, reservoir-rock deposition, sealrock deposition, overburden-rock deposition, trap formation, generation-migration-accumulation of petroleum, and preservation of petroleum; and (3) the critical moment, which is defined as the time that best depicts the generation-migrationaccumulation of hydrocarbons in a petroleum system (Magoon and Dow, 1994). The events chart serves only as a timeline and does not necessarily represent spatial relations.

Probabilities of occurrence of adequate charge, rocks, and timing were assigned to each assessment unit. Additionally, an access probability was assigned for necessary petroleumrelated activity within the assessment unit. All four probabilities, or risking elements, are similar in application and address the question of whether at least one undiscovered field of minimum size has the potential to be added to reserves in the next 30 years somewhere in the assessment unit. Each risking element thus applies to the entire assessment unit and does not equate to the percentage of the assessment unit that might be unfavorable in terms of charge, rocks, timing, or access.

Estimated total recoverable oil and gas volumes (cumulative production plus remaining reserves, called "known" volumes hereafter) quoted in this report are derived from Petroconsultants, Inc., 1996 Petroleum Exploration and Production database (Petroconsultants, 1996a). To address the fact that increases in reported known volumes through time are commonly observed, the U.S. Geological Survey (Schmoker and Crovelli, 1998) and the U.S. Minerals
Management Service (Lore and others, 1996) created a set of analytical "growth" functions that are used to estimate future reserve growth (called "grown" volumes hereafter). The set of functions was originally created for geologic regions of the United States, but it is assumed that these regions can serve as analogs for the world. This study applied the Federal Offshore Gulf of Mexico growth function (developed by the U.S. Minerals Management Service) to known oil and gas volumes, which in turn were plotted to aid in estimating undiscovered petroleum volumes. These estimates of undiscovered petroleum volumes therefore take into account reserve growth of fields yet to be discovered.

Estimates of the minimum, median, and maximum number, sizes, and co-product ratios of undiscovered fields were made based on geologic knowledge of the assessment unit, exploration and discovery history, analogs, and, if available, prospect maps. Probabilistic distributions were applied to these estimates and combined by Monte Carlo simulation to calculate undiscovered resources.

Several illustrations in this report that show boundaries of the total petroleum systems, assessment units, and extent of source rocks were compiled using Environmental Systems Research Institute's (ESRI) geographic information system (GIS) ARC/INFO and ESRI ArcView software. The political boundaries shown were taken with permission from ESRI's ArcWorld 1:3M digital coverage; these boundaries are not politically definitive and are displayed for general reference only. Oil and gas field centerpoints were provided by, and reproduced with permission from, Petroconsultants (1996a and 1996b). 


\section{Abstract}

The greater Paleozoic and Jurassic petroleum systems of the Arabian Peninsula form two of the most prolific petroleum-producing systems in the world. Source rocks of these systems extend throughout the eastern Arabian Peninsula and Arabian-Persian Gulf. Primary elements of these Paleozoic and Jurassic petroleum systems - source, reservoir, and seal rocks - are of great areal extent and exceptional quality. The combination of these regionally extensive, exceptional petroleum-system elements, and the formation of large subtle structural closures prior to, or coincident with, peak oil generation and migration, have produced oil and gas fields with reserve volumes second to none.

Two total petroleum systems (TPS), one of Paleozoic age and one of Jurassic age, in the central part of the Arabian Peninsula are identified in this report. The Central Arabia Qusaiba-Paleozoic TPS and the Arabian Sub-Basin Tuwaiq/ Hanifa-Arab TPS of Jurassic age encompass the Greater Ghawar Uplift Province (USGS Province 2021) and portions of adjoining geologic provinces. Structures that trap hydrocarbons in these systems are mostly (1) large, gentle anticlines formed from reactivated basement fault blocks, (2) salt domes that resulted from halokinesis, or (3) structural traps resulting from a combination of these two processes. Major tectonic events that created these structures resulted from early Zagros rifting during the Early Triassic and two Alpine tectonic episodes that occurred during the Late Cretaceous and middle to late Tertiary.

Hydrocarbons of the Central Arabia Qusaiba-Paleozoic TPS are sourced mainly by organic-rich, so-called "hot shale" that occurs in the basal part of the Lower Silurian Qusaiba Member of the Qalibah Formation. Oil and gas are produced mainly from sandstones of the Permian Unayzah and Devonian Jauf Formations, and from basal transgressive marine sandstones and cyclic, dolomitic shelf-carbonates of the Late Permian Khuff Formation. Two assessment units (AU) are recognized in the Central Arabia Qusaiba-Paleozoic TPS that are related to type of structural trap and presence of underlying Infracambrian salt: (1) the onshore Central Arch Horst-Block Anticlinal Oil and Gas AU, and (2) the mostly offshore North Gulf Salt Basin Structural Gas AU. The mean total volume of undiscovered resource for the Central Arabia QusaibaPaleozoic TPS is estimated at about 108 billion barrels of oil equivalent (BBOE).

Oil of the Arabian Sub-Basin Tuwaiq/Hanifa-Arab TPS is sourced by organic-rich, marine carbonates of the Jurassic Tuwaiq Mountain and Hanifa Formations. These source rocks were deposited in two of three intraplatform basins during the Jurassic and, where thermally mature, have generated a superfamily of oils with distinctive geochemical characteristics. Oils were generated and expelled from these source rocks beginning in the Cretaceous at about $75 \mathrm{Ma}$. Hydrocarbon production is from cyclic carbonate-rock reservoirs of the Arab Formation that are sealed by overlying anhydrite.
Several giant and supergiant fields, including the world's largest oil field at Ghawar, Saudi Arabia, produce mostly from the Arab carbonate-rock reservoirs. Two assessment units are also recognized in the Arabian Sub-Basin Tuwaiq/HanifaArab TPS that are similarly related to structural trap style and presence of underlying Infracambrian salt: (1) an onshore Horst-Block Anticlinal Oil AU, and (2) a mostly offshore Salt-Involved Structural Oil AU. The mean total volume of undiscovered resource for the Arabian Sub-Basin Tuwaiq/ Hanifa-Arab TPS is estimated at about 49 billion barrels of oil equivalent (42 billion barrels of oil, 34 trillion feet of gas, and 1.4 billion barrels of natural gas liquids).

\section{Introduction}

Three areally extensive, overlapping petroleum systems of Paleozoic, Jurassic, and Cretaceous age (fig. 1) have been recognized on the eastern half of the Arabian Peninsula (Alsharhan and Nairn, 1997). A fourth, earlier Infracambrian (Gulf PetroLink, 2000) petroleum system is found within the geographic limits of most rift salt basins of Infracambrian age. These four systems extend across eight USGS priority provinces (Ahlbrandt and others, 2000). Source, reservoir, and seal rocks of great geographic extent characterize each of these prolific hydrocarbon-producing systems of the eastern Arabian Peninsula. Total petroleum systems identified in this report are defined within more local, structurally bound provinces, and over a central area of the Arabian Peninsula where three intraplatform sub-basins developed during the Jurassic. Thus, total petroleum systems (TPS) described here are only part of the more areally extensive petroleum systems of the eastern Arabian Peninsula. The purpose of this report is to describe and outline the geologic framework, tectonic history, and characteristics, elements, evolution, and geographic extent and boundaries of the Paleozoic-age, Central Arabia Qusaiba-Paleozoic TPS (202101), and the Jurassic-age, Arabian Sub-Basin Tuwaiq/Hanifa-Arab TPS (202102). The geologic information in combination with the exploration and production histories is then used to present the geologic models for undiscovered petroleum resources for these two total petroleum systems. A third TPS, the Cretaceous-Tertiary TPS (203001), lies partly within the Arabian sub-basin and also extends into the Zagros and Mesopotamian areas (U.S. Geological Survey World Energy Assessment Team, 2000).

The central Arabian sub-basin portion of the Arabian Peninsula encompasses the Greater Ghawar Uplift Province (figs. 2 and 4) and portions of adjacent geologic provinces along the east-central Arabian Peninsula. The Central Arabia QusaibaPaleozoic and Arabian Sub-Basin Tuwaiq/Hanifa-Arab Total Petroleum Systems comprise areas within eastern Saudi Arabia, western Qatar, and the adjacent northern portion of the Arabian-Persian Gulf (North Gulf), where exceptional geochemical and geologic elements form these two stratigraphically stacked, world-class systems. An estimated two-thirds 


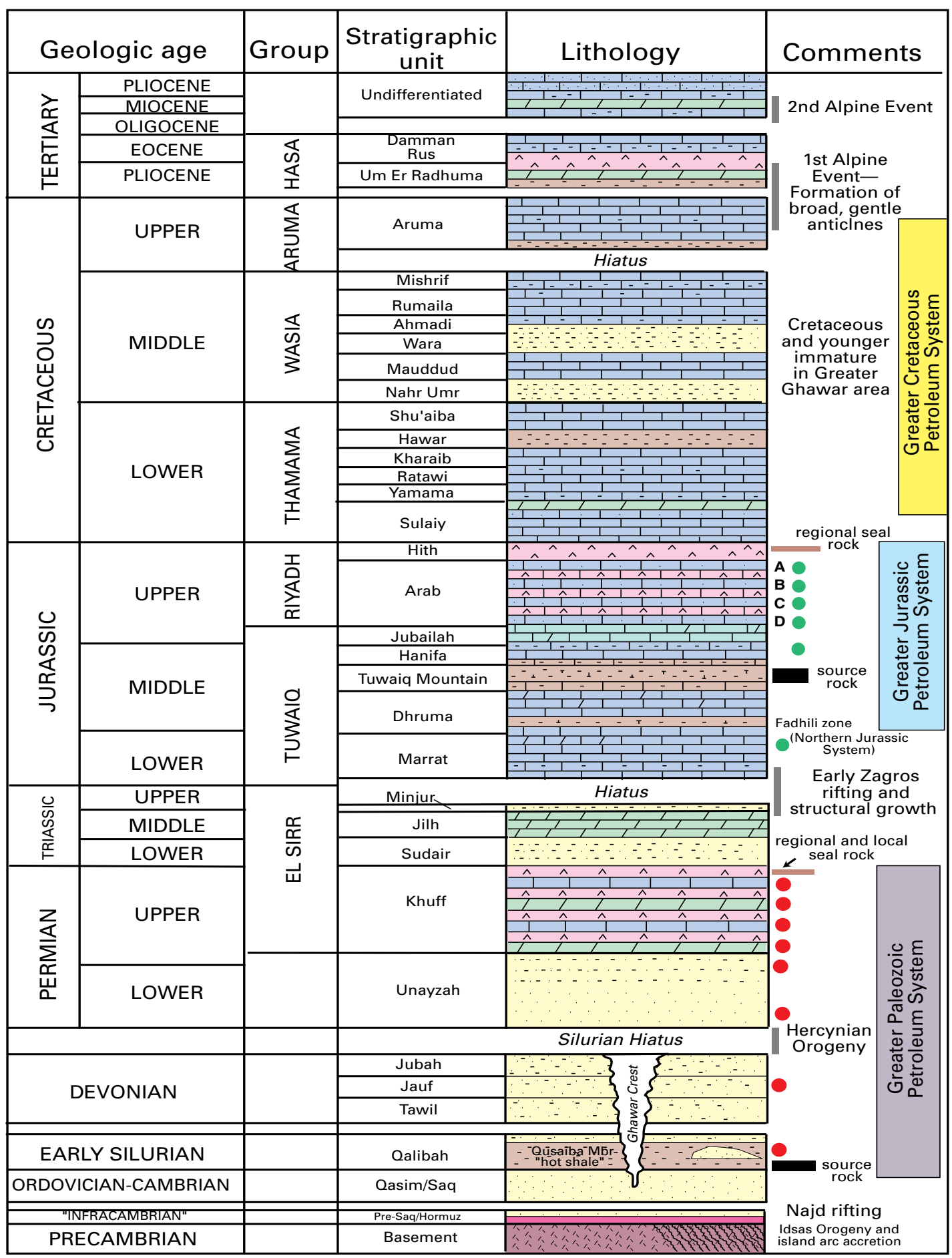

EXPLANATION

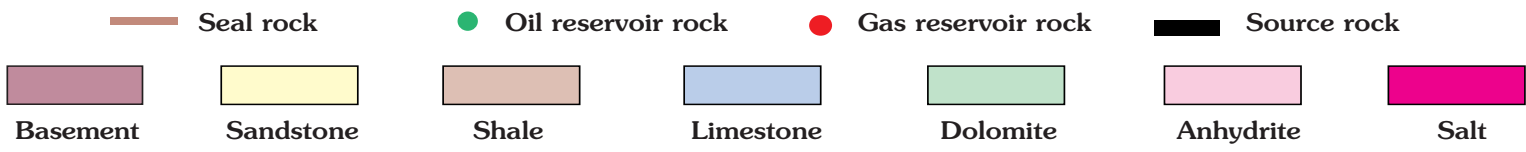

Figure 1. Stratigraphic section, major tectonic events, and stratigraphic units that make up the Greater Paleozoic, Jurassic, and Cretaceous petroleum systems of the eastern Arabian Peninsula. Modified from Jawad Ali and Al-Husseini (1996), Wender and others (1998), Janahi and Mirza (1991), Chaube and Al-Samahiji (1995), and Mendeck and Al-Madani (1995). 


\section{EXPLANATION}

Geologic provinces

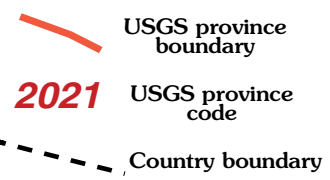

Primary age of reservoir in field

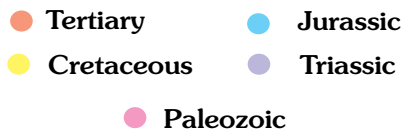

Field class

$\begin{array}{ll} & \text { Oil field } \\ & \text { Gas field }\end{array}$

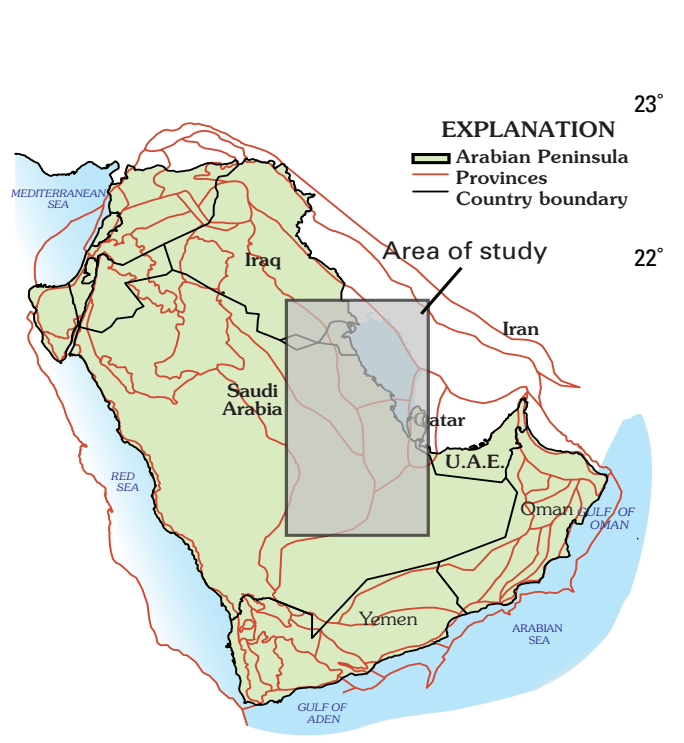

Figure 2. USGS geologic provinces of central Saudi Arabia and northern Arabian-Persian Gulf, oil and gas field centerpoints, and primary age of reservoir for each field. U.A.E., United Arab Emirates.

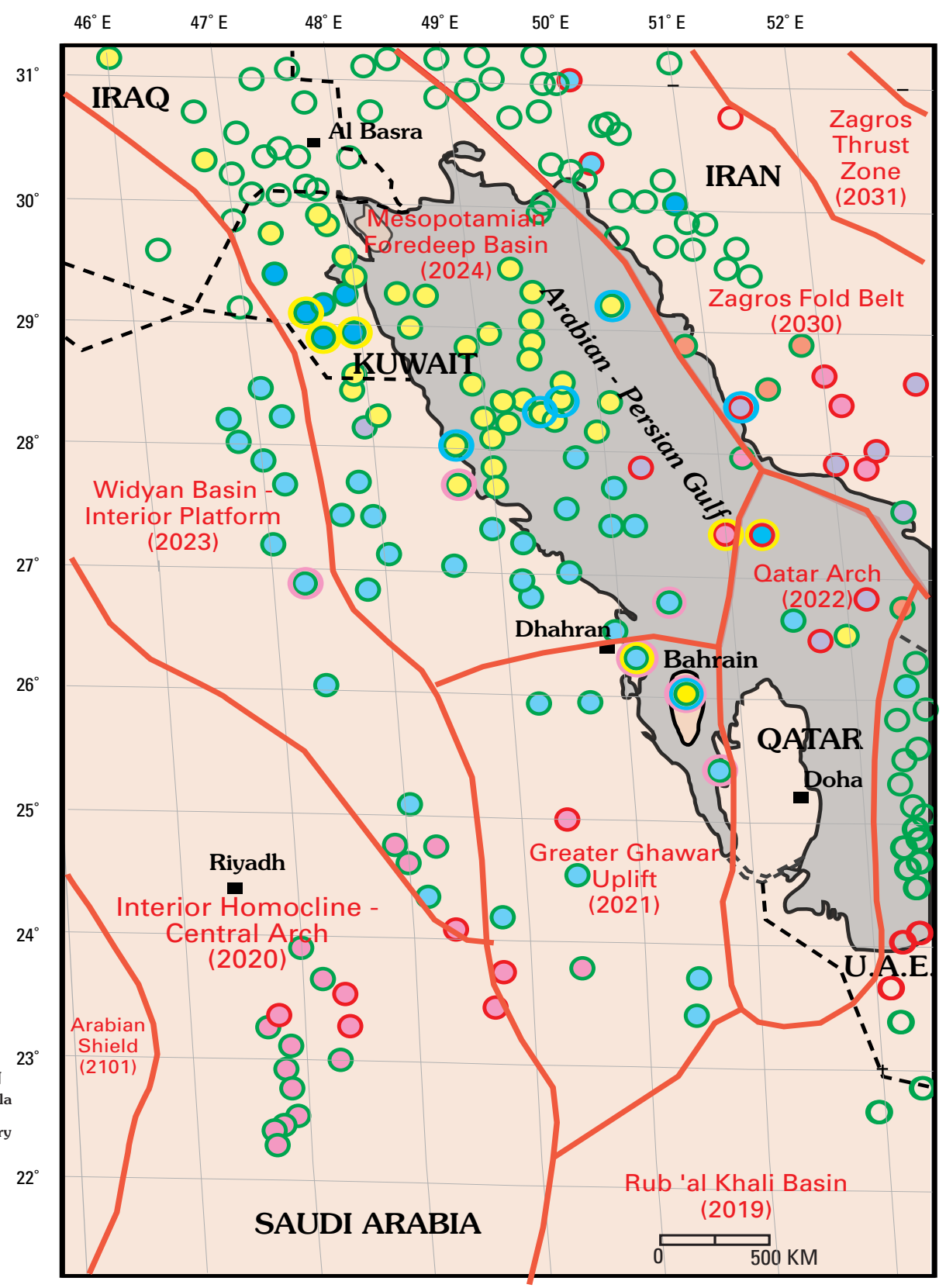


of the world's known ultimately recoverable oil is within, and adjacent to, the Arabian-Persian Gulf, where a thick sequence of sedimentary rocks was deposited in areally extensive basins along the eastern and southern parts of the Arabian Peninsula (Abu-Ali and others, 1991; Beydoun, 1991; Cole, Abu-Ali, and others, 1994; Cole, Carrigan, and others, 1994; Alsharhan and Nairn, 1997; BP Amoco, 2000; Sharland and others, 2001). This locale encompasses the area east of the Arabian Shield, along the Arabian-Persian Gulf, eastward to the Zagros Fold Belt and Oman Mountains, and within the political boundaries of Saudi Arabia, Kuwait, Iraq, Qatar, Bahrain, United Arab Emirates, Oman, Yemen, and Iran.

The USGS recently estimated that the Middle East and North Africa region (USGS Region 2) holds about 765 billion barrels of oil (BBO). This volume is 58 percent of the world's total known oil reserves, exclusive of the United States, of 1,326 BBO. Additionally, $706 \mathrm{BBO}$ (53 percent of the total exclusive of the United States) is from provinces within the Middle East portion (Klett and others, 1997). Subsequently, the U.S. Geological Survey World Energy Assessment Team (2000) estimated that of the USGS World Regions, the Middle East and North Africa region contains the greatest volume of the world's undiscovered oil and gas resources. In particular, the U.S. Geological Survey World Energy Assessment Team (2000) reported that USGS Region 2 has the greatest potential for undiscovered oil in the world (exclusive of the U.S.) with an estimated mean total volume of undiscovered technically recoverable oil of about $230 \mathrm{BBO}$. This represents more than 35 percent of the world's total estimated 649 billion barrels of undiscovered oil (exclusive of the U.S.). Region 2 ranks second on a global scale in undiscovered gas potential with an estimated volume of 1,370 trillion cubic feet (TCF) - about 30 percent of the world's 4,669 TCF total estimated undiscovered natural gas resource (exclusive of the U.S.). The Former Soviet Union (USGS Region 1) ranks first in undiscovered, recoverable natural gas with a mean estimate of 1,611 TCF. The Former Soviet Union, with a mean undiscovered oil volume estimated at 106 billion barrels, ranks second in undiscovered oil potential. Finally, Region 2 ranks first in mean undiscovered natural gas liquids (NGL) with about 82 BBNGL. This is about 40 percent of the world's total estimated undiscovered NGL (U.S. Geological Survey World Energy Assessment Team, 2000).

Paleozoic and Jurassic organic-rich source rocks of the Arabian-Persian Gulf (hereafter, Gulf) region form two of the most prolific petroleum-producing systems in the world (fig. 1 ); these systems also include regionally extensive reservoirs and seals and large structural traps that combine to form many supergiant oil and gas fields. The central Arabian total petroleum systems of Paleozoic and Jurassic age contribute most of Saudi Arabia's 261 billion barrels of proven oil reserves, more than one-fourth of the world total, with as much as 1 trillion barrels of oil in place (Energy Information Administration, 2000). Although Saudi Arabia has about 80 oil and gas fields, more than half of its oil reserves are contained in only eight fields. Two of these eight fields are classified as the world's largest oil fields, both located within the Greater Ghawar Uplift Province of this report. Ghawar field, Saudi Arabia, produces both oil and gas from the Jurassic and Paleozoic systems and has estimated known reserves of about $115 \mathrm{BBO}$ and remaining reserves of about $70 \mathrm{BBO}$. Safaniya field, the world's largest offshore oil field, has estimated reserves of 19 billion barrels (Energy Information Administration, 2000). Immediately south of the Greater Ghawar Uplift Province, and in the Rub 'al Khali Province, a Paleozoic total petroleum system encompassing the Rub 'al Khali Basin is sourced by the same Lower Silurian organic-rich shale. In this area, nonassociated gas generated from Silurian shale is produced from Permian carbonate reservoirs in North field, the largest single gas field in the world, which lies in the offshore gulf waters of Qatar and Iran. Within Qatar alone, North field has proven reserves estimated at about 300-400 TCFG; total recoverable reserves for all of North field are estimated at about 500 TCFG (Alsharhan and Nairn, 1997; Al-Siddiqi and Dawe, 1999).

Most oil in the central Arabian intraplatform sub-basin was generated and produced from a Jurassic carbonate-rock petroleum system (figs. 1 and 4). However, oil generated within petroleum systems of Cretaceous and Paleozoic age also accounts for production in reservoirs of Cretaceous and Paleozoic age from other numerous giant fields in, or adjacent to, the east-central Arabian Peninsula. The east-central Arabian Peninsula and Arabian-Persian Gulf area is rich in petroleum because this locale was once an areally extensive depositional platform along a pre-Mesozoic passive margin of Gondwana. Subsequent development of multiple intraplatform basins, extensive source-rock deposition within these intraplatform basins, and multiple tectonic stages of compression and extension produced large subtle structural closures prior to, or coincident with, peak oil generation and migration. Finally, the large petroleum resource base was contained by efficient horizontal hydrocarbon migration into traps underlying thick, regionally extensive evaporite seals of Cambrian, Permian, Jurassic, and Tertiary age (Murris, 1980; Ayres and others, 1982; Beydoun, 1991; Cole, Abu-Ali, and others, 1994; Cole, Carrigan, and others, 1994; Alsharhan and Nairn, 1997, Konert and others, 2001; Zeigler, 2001; among others).

\section{Acknowledgments}

The manuscript has benefited greatly from critical and constructive reviews by Tom Ahlbrandt, Chris Schenk, and Kathy Varnes. The author thanks Lorna Carter for a constructive edit of the manuscript. The author is grateful to Gulf PetroLink, publisher of GeoArabia, for permission to publish numerous figures that were modified for this manuscript.

\section{U.S. Geological Survey Geologic Provinces of Central Saudi Arabia and Gulf Area}

Although focused on the Greater Ghawar Uplift Province (2021), the total petroleum systems of this report encompass parts of other adjoining structural provinces in central Saudi 


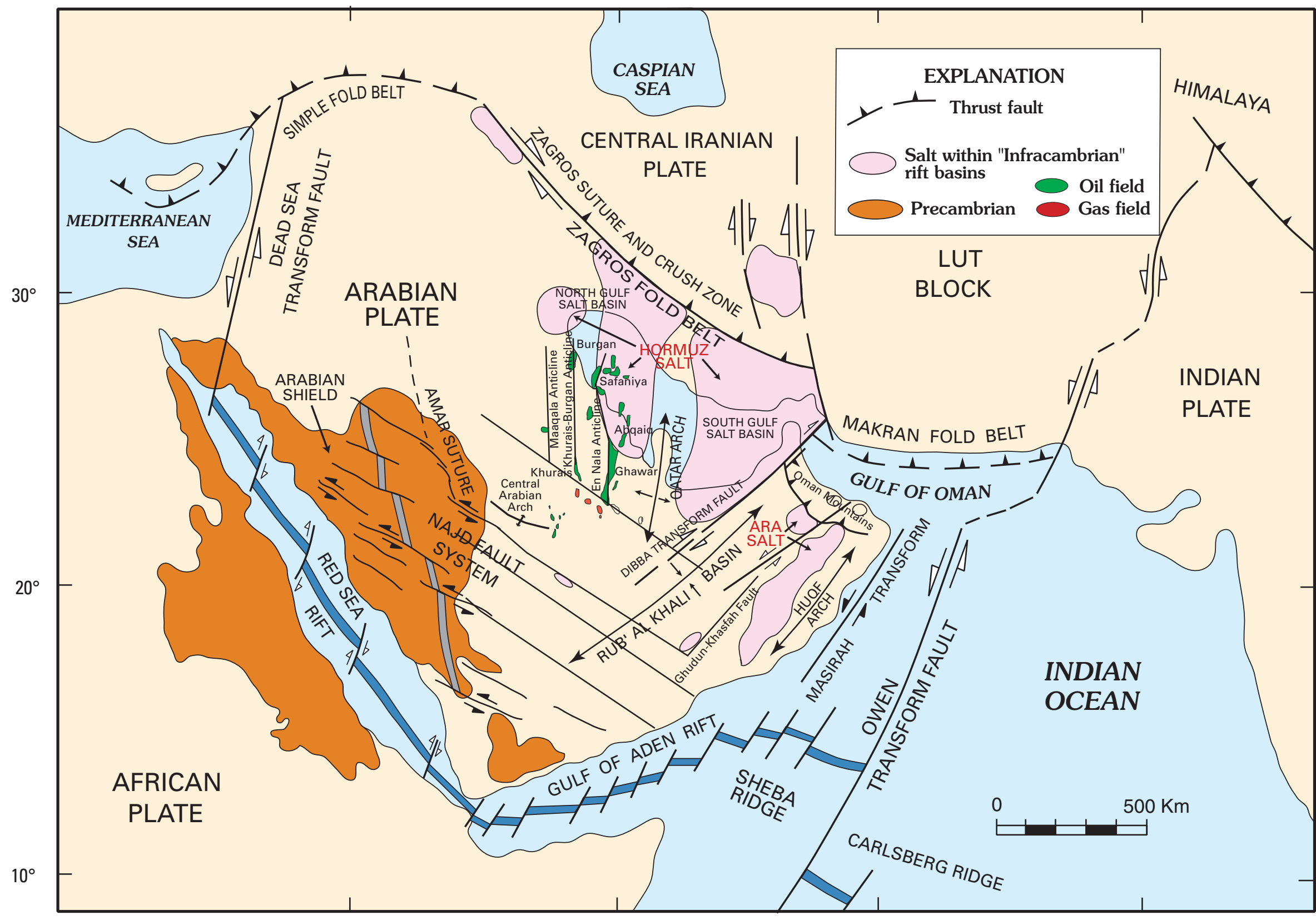

Figure 3. Arabian Plate showing general tectonic and structural features, Infracambrian rift salt basins, and oil and gas fields of Central Arabia and North Gulf area. Modified from Al-Husseini (2000). 


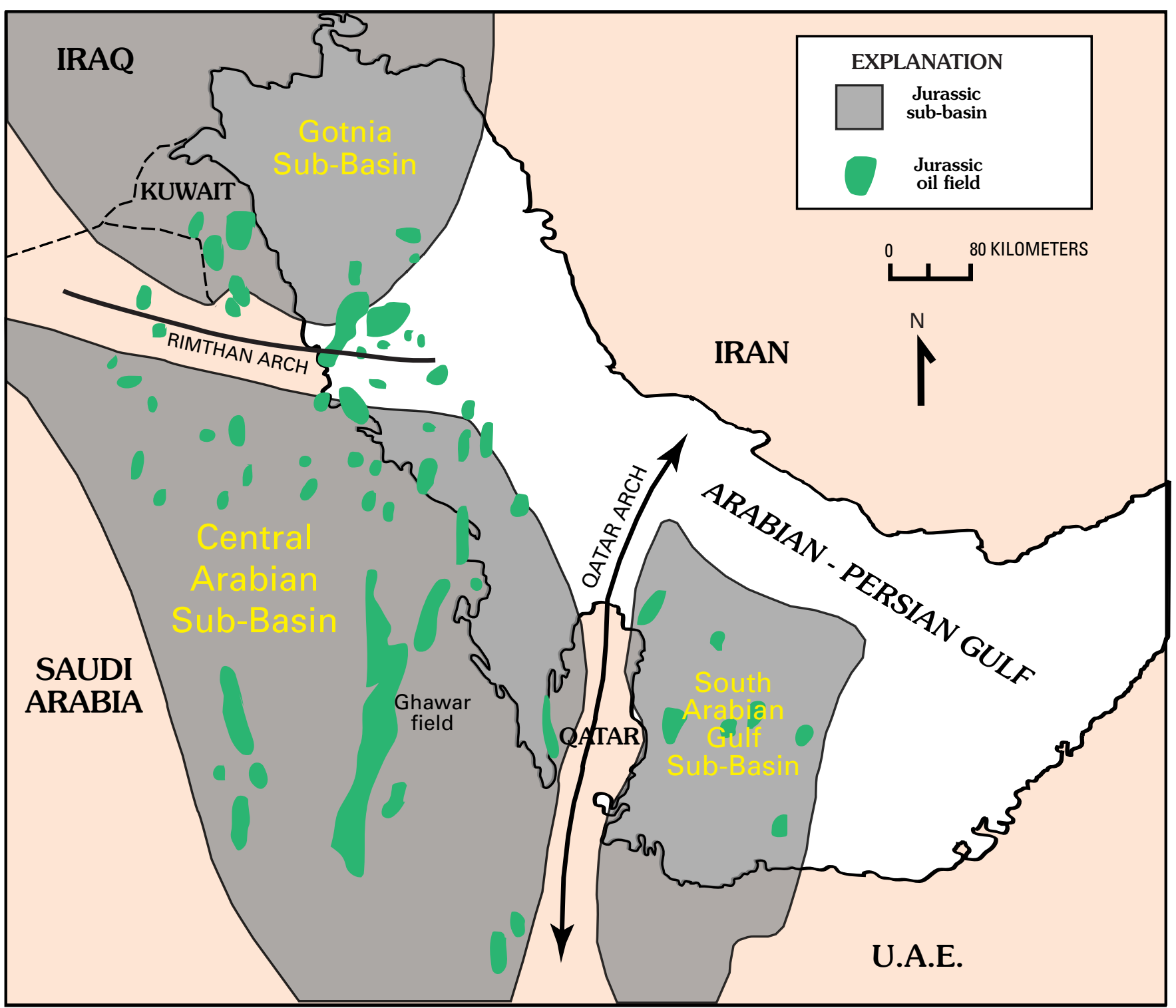

Figure 4. Jurassic intraplatform sub-basins of Arabian-Persian Gulf region. Modified from Murris (1980), Alsharhan and Kendall (1986), Alsharhan and Magara (1994), and Grabowski and Norton (1995). U.A.E., United Arab Emirates.

Arabia and northern portion of the Gulf area as defined by the USGS (Klett and others, 1997; Pollastro and others, 1999). The Interior Homocline-Central Arch Province (2020) borders the Greater Ghawar Uplift Province to the west (fig. 2). The Interior Homocline-Central Arch Province is structurally defined by gently dipping sedimentary rocks that extend eastward from the Arabian Shield (fig. 3) into the Widyan Basin-Interior Platform Province. This structure continues into the Mesopotamian Foredeep Basin Province (2024) to the east. The structural transition from the Interior Homocline into the Interior Platform is marked by a break in slope; flat-lying rocks form a platform or terrace to the east. An eastward-trending basement ridge, centered along lat $24^{\circ}$ N., forms the Central Arabian Arch (fig. 3). The arch extends eastward from the Arabian Shield toward the Qatar Peninsula and is within the south half of the Interior Homocline-Central Arch Province. It separates the northeast-dipping, central segment of the stable shelf from the southern, east-dipping segment and has a complex geologic history (Al-Kadhi and Hancock, 1980). The Central Arabian Arch, which apparently originated during the Precambrian, influenced sedimentation during the Phanerozoic and controls the south plunge on hydrocarbon-bearing anticlinal closures to the northeast (Ayres and others, 1982). The Central Arabian Arch also forms part of the north-northwest structural margin of the Rub 'al Khali Basin Province (2019) to the south (fig. 3). The arch was slightly positive during the early Paleozoic, as pre-Permian sediments seem to pinch out against it (Powers and others, 1966). Strong upwarping occurred during 
post-Early Devonian and pre-Late Permian times, when older sediments were peneplaned and stripped from the crest of the arch. Later submergence allowed deposition of Late Permian carbonates directly upon the basement across the axis and for some distance to the north and south (Powers and others, 1966; Alsharhan and Nairn, 1997).

Adjacent to and north of the Greater Ghawar Uplift Province is the Mesopotamian Foredeep Basin Province (2024), an area covered by Quaternary fluvial-plain, eolian, and lacustrine deposits. The Mesopotamian Foredeep Basin Province is bordered on the east-southeast and east-northeast by the Qatar Arch Province (2022) and Zagros Fold Belt Province (2030), respectively (fig. 2).

In a global ranking of geologic provinces by known petroleum volume (cumulative production plus reserves) in terms of billion barrels of oil equivalent (BBOE) exclusive of the United States, the USGS showed that the Greater Ghawar Uplift Province, although geographically rather limited, ranked third, contributing nearly 8 percent (191.7 BBOE) of the world total. The adjacent Mesopotamian Foredeep Basin Province ranked second with almost 14 percent (344 BBOE), the Rub 'al Khali Basin Province ranked fifth with about 5 percent (122.8 BBOE), and the Qatar Arch Province ranked sixth with about 4 percent ( $92.5 \mathrm{BBOE}$ ) of the world's total known petroleum volume (Klett and others, 1997; 2000).

\section{Greater Petroleum Systems of the Eastern Arabian Peninsula}

The greater Paleozoic and Jurassic petroleum systems of the eastern Arabian Peninsula are extensive in both geographic scale and hydrocarbon-producing potential; each includes a regionally extensive source facies. For this study, these extensive petroleum systems have been locally partitioned into total petroleum systems (Ahlbrandt and others, 2000; Magoon and Schmoker, 2000) along a north-south trend. Some of these total petroleum systems closely correspond geographically to the Late Jurassic intraplatform sub-basins shown in figure 4 (Murris, 1980; Alsharhan and Kendall, 1986; Al-Husseini, 1997; Mahmoud and others, 1992; Cole, Abu Ali, and others, 1994; Cole, Carrigan, and others, 1994; Bishop, 1995; Milner, 1998; Abu-Ali and others, 1999; Jones and Stump, 1999; Zeigler, 2001). In the USGS World Petroleum Assessment (U.S. Geological Survey World Energy Assessment Team, 2000), names of the total petroleum systems (TPS) were determined by age and (or) geologic names of the major source and reservoir rocks. For the assessment of the eastern Arabian Peninsula, three separate Paleozoic and Jurassic total petroleum systems are defined and described to more accurately represent local variations in the more regionally extensive, greater Paleozoic and Jurassic petroleum systems (Ahlbrandt and others, 2000). The three Paleozoic total petroleum systems are defined from north to south as follows: (1) the Paleozoic Qusaiba/Akkas/Abba/Mudawwara TPS (202301), described by Fox and Ahlbrandt (2002), encompasses an area in Saudi Arabia north of the Central Arabian Arch and Hercynian unconformity, the western and southwestern deserts of Iraq, and eastern portions of Syria and Jordan (fig. 5); (2) the Central Arabia Qusaiba-Paleozoic TPS (202101), described in this report, encompasses the entire Greater Ghawar Uplift Province (2021) and portions of surrounding provinces (fig. 6) including much of the North Gulf Salt Basin (fig. 3); and (3) the Silurian Qusaiba TPS (201903) of the Rub 'al Khali Province (2019; fig. 7) that also encompasses much of the South Gulf Salt Basin (Schenk and Pollastro, 2000; Pollastro, Schenk, and Ahlbrandt, 2002) (fig. 3).

Similarly, the greater Jurassic petroleum system of the eastern Arabian Peninsula was locally partitioned into three total petroleum systems similar to those of the Paleozoic. In Kuwait and the northern part of the North Gulf Salt Basin (fig. 3) within the Jurassic Gotnia intraplatform sub-basin (figs. 4 and 5) is the Jurassic Gotnia/Barsarin/Sargelu/Najmah TPS (202302), described in Fox and Ahlbrandt (2002) (fig. 5). In central Saudi Arabia and northern part of the Gulf, a total petroleum system sourced by hydrocarbons from the Jurassic Arabian intraplatform sub-basin is designated as the Arabian Sub-Basin Tuwaiq/Hanifa-Arab TPS (202102) (figs. 5 and 6). The Arabian Sub-Basin Tuwaiq/Hanifa-Arab TPS, described in this report, encompasses the entire Greater Ghawar Uplift Province (2021) and the southern part of the Mesopotamian Foredeep Basin Province (2024) in the northern part of the Gulf that includes the North Gulf Salt Basin (fig. 3). The Jurassic Hanifa/Diyab-Arab TPS (201902) is the TPS designated for the southern part of the Gulf region and Rub 'al Khali Basin Province (2019) of Saudi Arabia, United Arab Emirates (U.A.E.), Qatar, eastern Oman, and northeastern Yemen (fig. 7).

\section{Tectonic Evolution and Structural Setting}

The present-day Arabian Plate (fig. 3) is bounded by a variety of complex tectonic regimes. The southern and western margins of the Arabian Plate are Oligocene-Miocene rift margins where spreading and rotation formed the Red Sea and Gulf of Aden (fig. 3). The eastern and northern margins of the Arabian Plate are compressional tectonic settings that formed the Zagros Fold Belt of southwestern Iran, the Simple Fold Belt of southwestern Turkey, and the Makran Fold Belt where subduction occurs in the Gulf of Oman (fig. 3) (Al-Husseini, 2000; Sharland and others, 2001; Konert and others, 2001).

Sharland and others (2001) summarized the tectonic evolution of the Arabian Plate in five phases as follows:

1. A Precambrian compressional phase (from 715 to 610 $\mathrm{Ma}$ ) of island-arc and microcontinent terrane accretion that led to the assembly of the Arabian Plate;

2. A late Precambrian to Late Devonian extensional phase (from 610 to $364 \mathrm{Ma}$ ) when the plate was located in an 


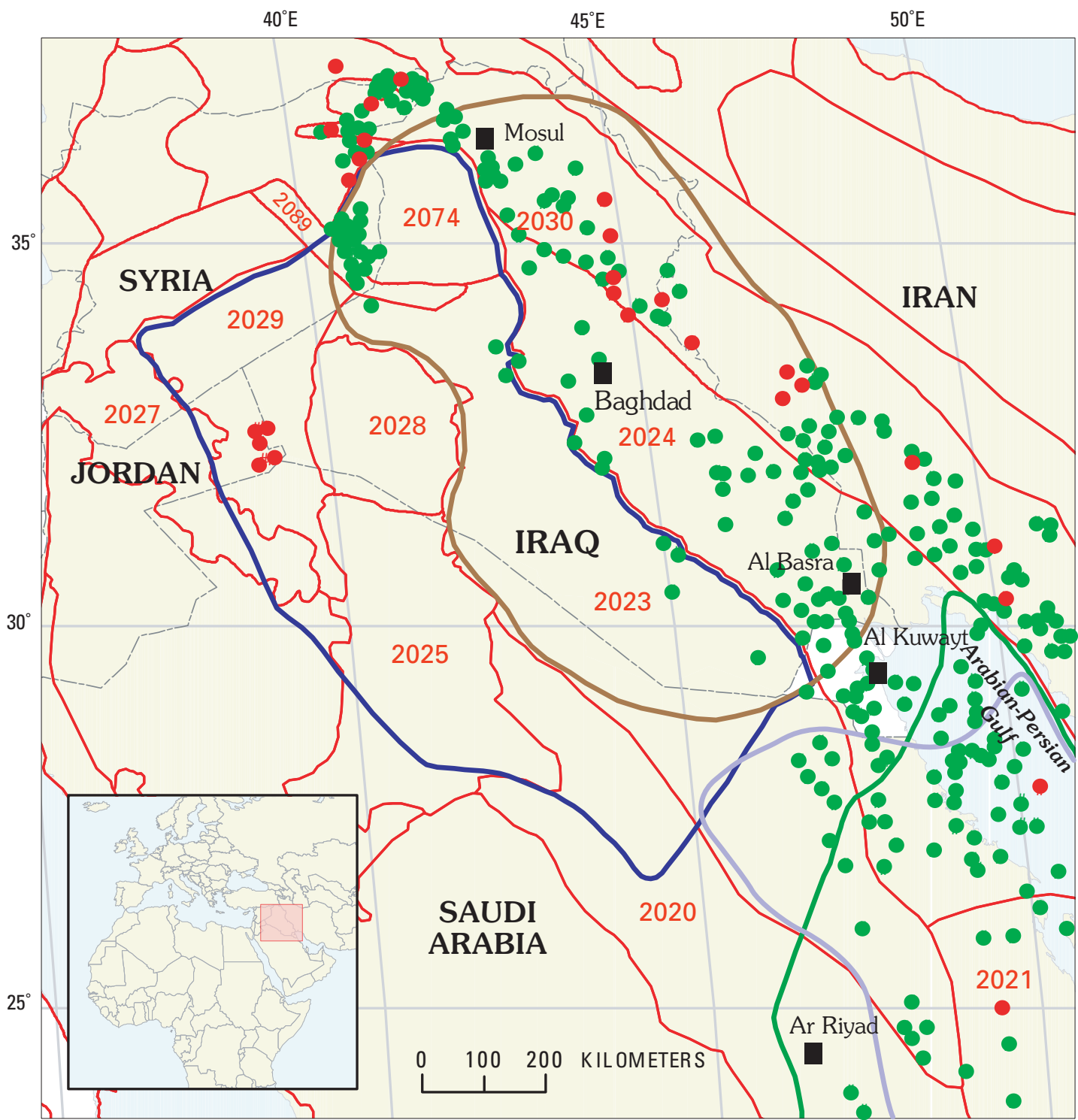

\section{EXPLANATION}

2020 USGS Geologic Province Boundary and number

Paleozoic Qusaiba/Akkas/Abba/Mudawwara Total Petroleum System (202301)

\section{Jurassic Gotnia/Barsarin/Sargelu/Najmah} Total Petroleum System (202302)

\section{Central Arabia Qusaiba-Paleozoic} Total Petroleum System (202101)

\section{Arabian Sub-Basin Tuwaiq/Hanifa-Arab} Total Petroleum System (202102)

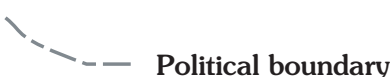

Gas field centerpoint

Oil field centerpoint

Figure 5. Paleozoic Qusaiba/Akkas/Abba/Mudawwara and Jurassic Gotnia/Barsarin/Sargelu/Najmah Total Petroleum Systems of Gotnia sub-basin. Portions of Central Arabia Qusaiba-Paleozoic and Jurassic Arabian Sub-Basin Tuwaiq/Hanifa-Arab Total Petroleum Systems are also shown in lower right portion of map. 


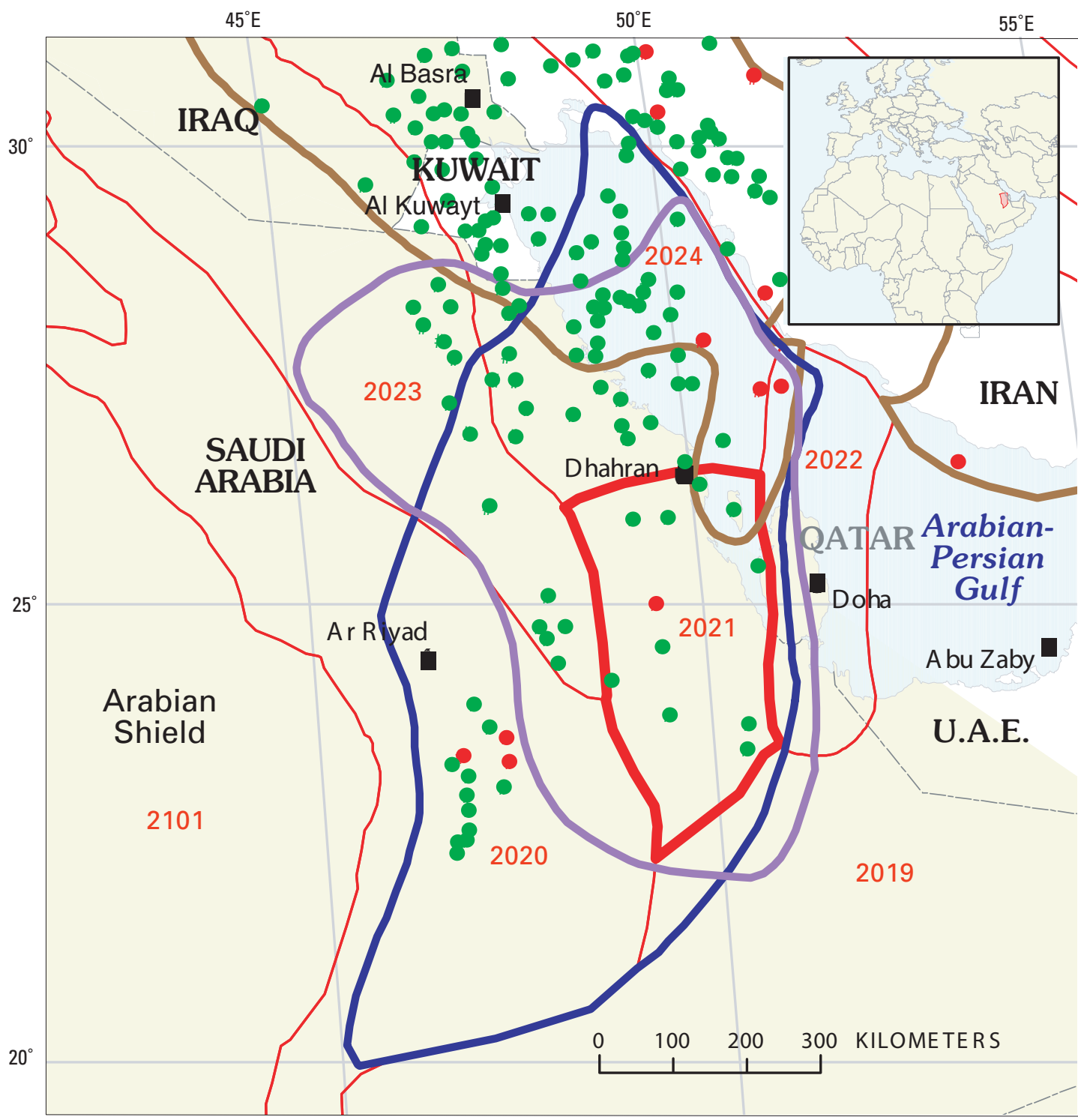

\section{EXPLANATION}

Central Arabia Qusaiba-Paleozoic

Total Petroleum System (202101)

Arabian Sub-Basin Tuwaiq/Hanifa-Arab

Total Petroleum System (202102)

Zagros-Mesopotamian Cretaceous-

Tertiary Total Petroleum System (203001)

Oil field centerpoint

- Gas field centerpoint

Greater Ghawar Uplift Province (2021)

USGS province boundary

Political boundary

Figure 6. USGS geologic provinces, oil and gas field centerpoints, and Cretaceous-Tertiary, Jurassic, and Paleozoic total petroleum systems of central Saudi Arabia and northern Arabian-Persian Gulf. Note location of the Greater Ghawar Uplift Province (2021). U.A.E., United Arab Emirates. 


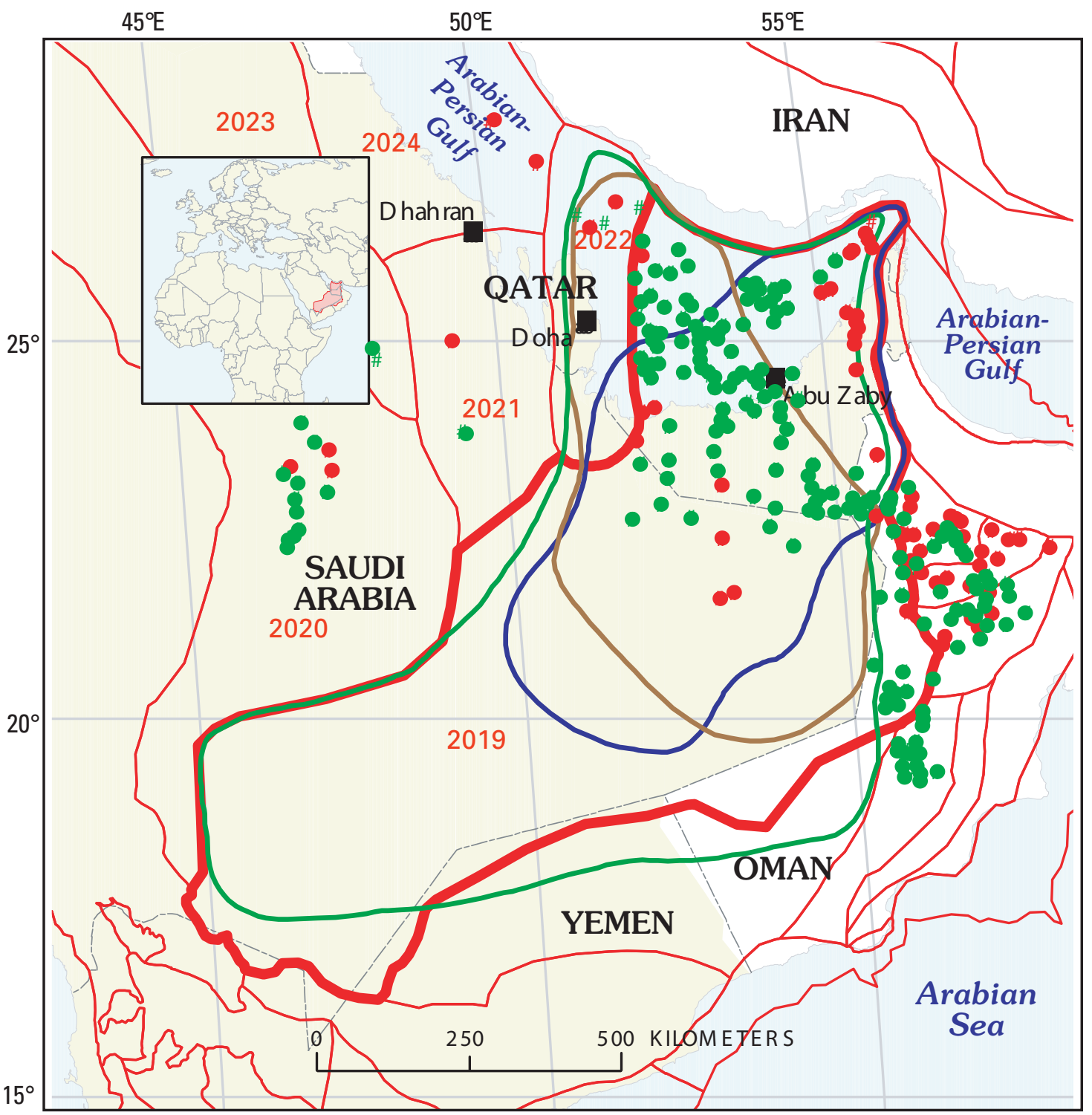

\section{EXPLANATION}

Cretaceous Thamama/Wasia Total Petroleum System (201901)

Jurassic Hanifa/Diyab-Arab Total Petroleum System (201902

Silurian Qusaiba Total Petroleum System (201903)

Oil field centerpoint

Gas field centerpoin

$\longrightarrow$

Rub 'al Khali Basin Province (2019)

USGS geologic province boundary

2021 USGS geologic province number

Political boundary

Figure 7. Cretaceous, Jurassic, and Paleozoic total petroleum systems and oil and gas field centerpoints of Rub 'al Khali Province (2019) in area of South Arabian Gulf intraplatform sub-basin. 
intracratonic setting in low to moderate latitudes with a passive margin to the Paleo-Tethys Sea. This phase contained the first preserved sediment deposited within the extensional rift basins formed from the Najd fault system (fig. 3);

3. A Late Devonian to mid-Permian phase (from 364 to $255 \mathrm{Ma}$ ) when the plate was located in a general back-arc setting in moderate southern latitudes and partly coeval with the "Hercynian Orogeny." This phase started and finished with extensional stresses, separated by a period of compression;

4. A largely Mesozoic extensional phase (from 255 to $92 \mathrm{Ma}$ ) when the plate was located in an equatorial setting and progressive continental rifting occurred around the plate, leading to north- and southeast-facing passive margins. Late Permian, Triassic, and Jurassic sedimentation was dominated by carbonate-evaporite deposition, and Early Cretaceous was dominated by open-marine mixed clastic-carbonate deposits; and

5. A late Mesozoic to present-day phase (from $92 \mathrm{Ma}$ to present) during which the plate was located in a compressive, broadly active margin setting in essentially its presentday position. This phase commenced with the onset of the first ophiolite obduction in Oman onto the previously passive margin with numerous subsequent obductions. This phase resulted in development of a narrow foredeep basin, closure of the Neo-Tethys Sea (fig. 8), uplift of the Oman Mountains and Zagros Fold Belt, and rifting and spreading of the Gulf of Aden and Red Sea.

Sharland and others (2001) also described in detail the sequence stratigraphy of the Arabian Plate. Through the stratigraphy, Sharland and others (2001) identified, dated, and correlated maximum flooding surfaces (MFS) across the Arabian Plate and provided time lines for chronostratigraphic interpretations. These sequence stratigraphic interpretations of the Arabian Plate place source, reservoir, and seal lithologies in a chronostratigraphic framework and allow identification, characterization, and construction of each petroleum system element within specific time intervals.

The great hydrocarbon-bearing traps of the Arabian Plate subsequently resulted as reactivated structures from the Precambrian Amar Collision between about 640 and 620 million years ago (Ma). The collision occurred along the north-trending Amar Suture that bisects the Arabian Peninsula at about long $45^{\circ}$ E. (fig. 3) and formed a regional, systematic and regular north-, northeast-, and northwest-trending structural pattern as a result of compression. For example, Ghawar field and Safaniya field are located on the 500-km-long, north-trending En Nala Anticline (fig. 3) (Al-Husseini, 2000). Immediately to the east of the En Nala Anticline is the northtrending Qatar Arch, and to the west is another 500-km-long, north-trending anticline, the Khurais-Burgan Anticline, that extends from Saudi Arabia's Khurais field to Kuwait's Burgan field, the world's second largest oil field (fig. 3).

The Amar Collision was followed by a widespread extensional collapse of the Arabian Shield between about 620 and $530 \mathrm{Ma}$, during which the north-trending anticlines probably remained elevated as elongated horsts bounded by faults
(Al-Husseini, 2000). During the final extensional stage (about 570 to $530 \mathrm{Ma}$ ), the regional, northwest-trending Najd fault system was developed. The Najd fault system dislocated the Arabian Shield left-laterally by about 250-300 km during this final extensional stage and formed a series of complementary northeast-trending rift basins (fig. 3) in the Arabian-Persian Gulf, Oman, Yemen, Pakistan, the Rub 'al Khali Basin, and Zagros Mountains (Schmidt and others, 1979; Brown and others, 1989; Loosveld and others, 1996; Oterdoom and others, 1999; Al-Husseini, 2000; Konert and others, 2001; Sharland and others, 2001; Zeigler, 2001). The rift basins are approximately perpendicular to the Najd fault zone and the orogenic collision front and are related to escape tectonism (Molnar and Tapponier, 1975; Stern, 1994; Webster, 2000; Blood, 2001).

Major subsiding rift basins of the Arabian-Persian Gulf, Oman, and Rub 'al Khali areas formed during Infracambrian and Early Cambrian time. During this period the Arabian Plate was close to the equator (Konert and others, 2001), and massive salt was deposited in these restricted rift basins early in their history (Gorin and others, 1982; Husseini and Husseini, 1990; Mattes and Conway-Morris, 1990; Al-Husseini, 2000). Oterdoom and others (1999) reported that in Oman, this rifting period, which was between about 570 and $530 \mathrm{Ma}$, is represented by deposition of the Infracambrian Huqf Supergroup. In the eastern Arabian Peninsula, these Infracambrian rift salt basins include, but are not restricted to, the Hormuz Salt basins of the Gulf area and the Ghaba, Fahud, and South Oman (Ara) salt basins of Oman (fig. 3). Smaller scale Infracambrian rift basins of similar origin and sedimentary fill have recently been reported or recognized on seismic profiles in the central and eastern portion of the Rub 'al Khali Basin and along the main Najd fault trend (Dyer and Al-Husseini, 1991; Faqira and Al-Hawuaj, 1998; Milner, 1998; Blood, 2000, 2001; Al-Husseini, 2000; Konert and others, 2001; Sharland and others, 2001; Zeigler, 2001) (fig. 3). Because these rift basins contain thick salt deposits and multiple, stacked petroleum systems of Infracambrian through Tertiary age, they play an important role in the occurrence and migration of hydrocarbons, and in hydrocarbon trap formation throughout the eastern Arabian Peninsula.

A thick sequence of Phanerozoic sediments (greater than $12,000 \mathrm{~m}$ ) accumulated along the eastern Arabian Peninsula and present-day Arabian-Persian Gulf (fig. 9). In this area, a pre-Mesozoic depositional basin, the Greater Arabian basin, was of extraordinary extent-thousands of kilometers long by about 2,000 km wide. From a structural standpoint, it was quite flat, thus providing an ideal setting for deposition on a large geographic extent of source, reservoir, and seal rocks (Murris, 1980; Beydoun, 1991; Cole, Abu Ali, and others, 1994; Cole, Carrigan, and others, 1994; Alsharhan and Nairn, 1997). Progressive burial of the geographically extensive source, reservoir, and seal rocks on a gentle structural setting allowed for efficient horizontal migration that could drain large, mature petroleum-generating source areas into extraordinarily large gentle structural closures. In particular, deposition of thick and areally extensive evaporite seals, combined 


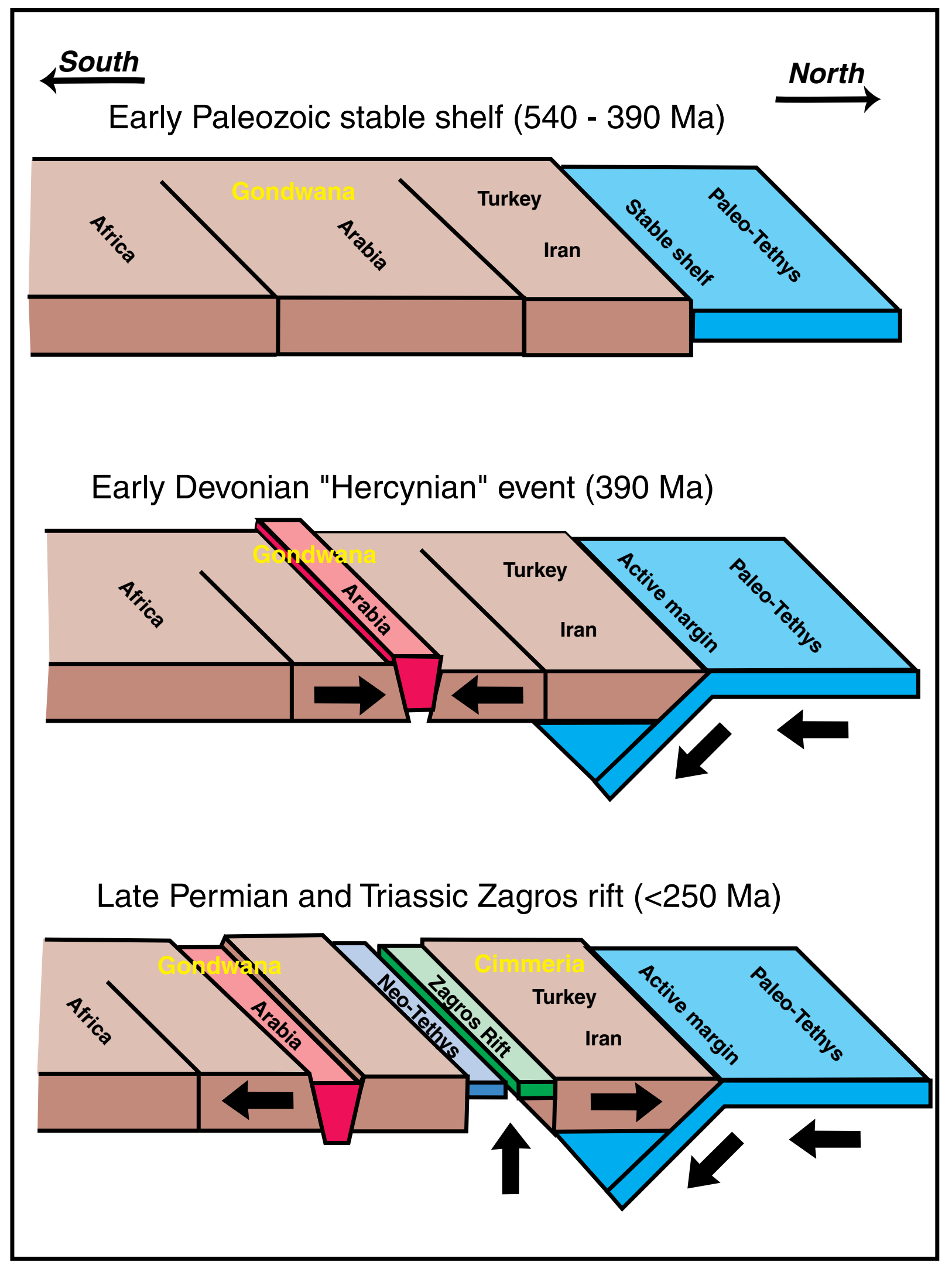

Figure 8. Evolution of Arabian Plate tectonics from early Paleozoic to Late Permian and Triassic, showing Early Devonian "Hercynian" compressional event and Early Zagros rifting event. Modified from McGillivray and Husseini (1992). 


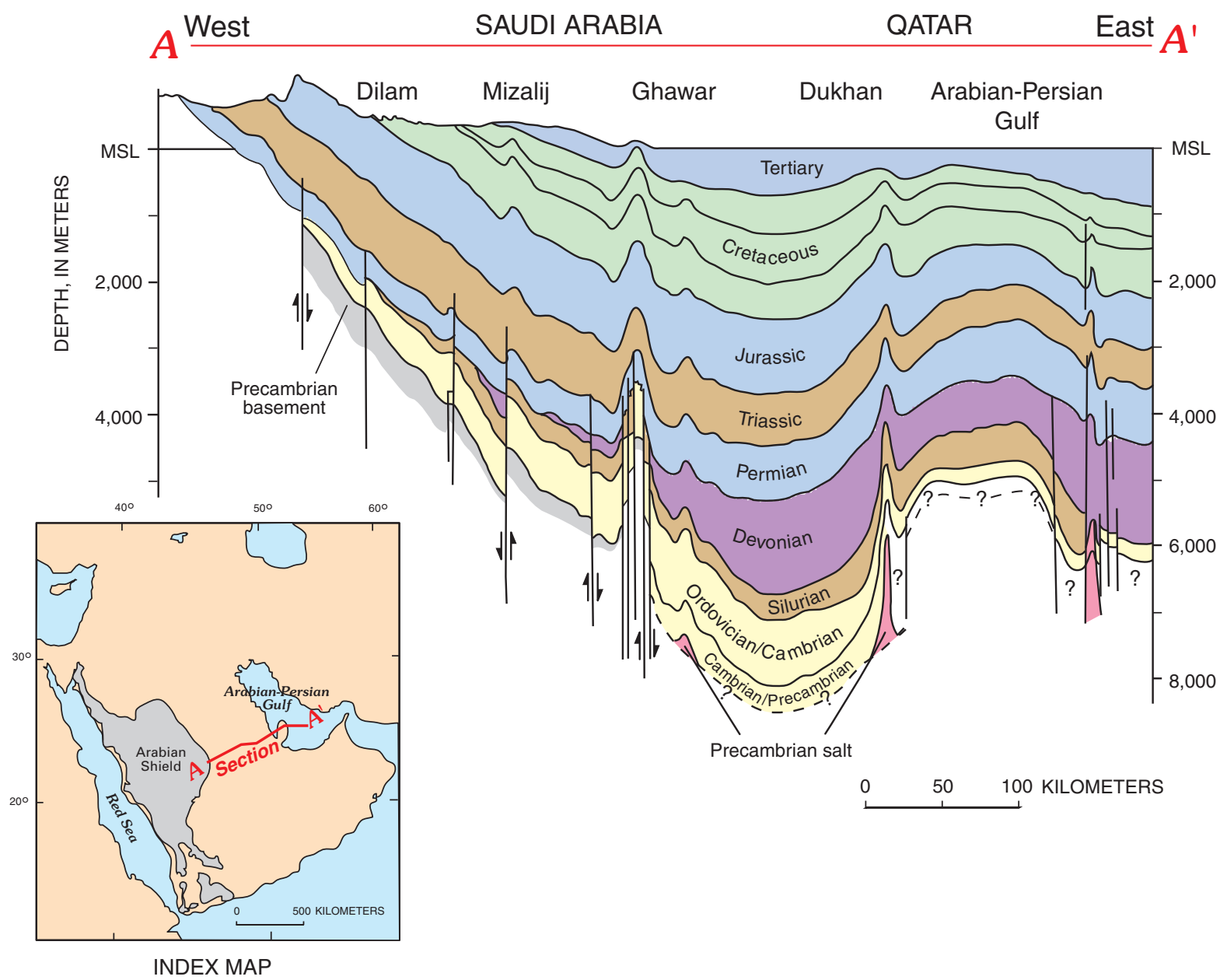

Figure 9. Geologic cross section across Saudi Arabia and Qatar from Arabian Shield to Arabian-Persian Gulf showing basement reverse faults and Precambrian (Infracambrian) salt. Modified from Alsharhan and Nairn (1997) and Konert and others (2001). Barbs show relative movement on faults.

with this gentle structural setting, allowed only minimal loss of hydrocarbons through fractures. Trapping in this multiple, stacked petroleum systems setting was aided by multiple tectonic stages and the halokinesis of thick underlying salt that resulted in reactivation or continued growth of primary anticlinal and domal structures. Additionally, peak oil generation coincided with major structural growth events in the foreland forming the multiple giant and supergiant fields that mark this petroleum-rich area along the eastern Arabian Peninsula and Gulf area.

During the Devonian, a structural event interpreted as a crustal response to compression uplifted central Arabia and tilted the Arabian Plate eastward (Husseini, 1991). As a result, the northeast margin of Gondwana was transformed from a passive to an active compressional margin (Beydoun, 1991). This major tectonic event, the Hercynian Orogeny, had a dramatic effect on the geology of the Arabian Peninsula (fig. 8). Changes in basin geometry, regional uplift, basement-cored uplifts, and the evidence of folding and inversion tectonics suggest that the Arabian Plate underwent multiple phases of compression during the Hercynian Orogeny (Konert and others, 2001). In particular, the Hercynian event caused reactivation of basement structures and formed major northsouth-trending, basement-involved horst blocks in central and eastern Saudi Arabia. These reactivated basement-involved structures were later sites of extensive erosion and structural trap formation that were favorable for hydrocarbon accumulation (figs. 10 and 11). The north-south-trending Hercynian uplifts, such as Ghawar (on which the Ghawar field is located), are bounded by reverse faults (fig. 9), suggesting that the uplift was due to a regional compressive stress field.

Following Hercynian uplift, structural development was less significant during the Permian, and the Arabian Plate was essentially a passive margin setting (McGillivray, 1994). The first extensive deposits following the Hercynian Orogeny were braided-plain, channel-fill, and eolian clastics resting on the angular Hercynian unconformity. The post-Hercynian sedimentation pattern then shifted from a primarily siliciclastic 


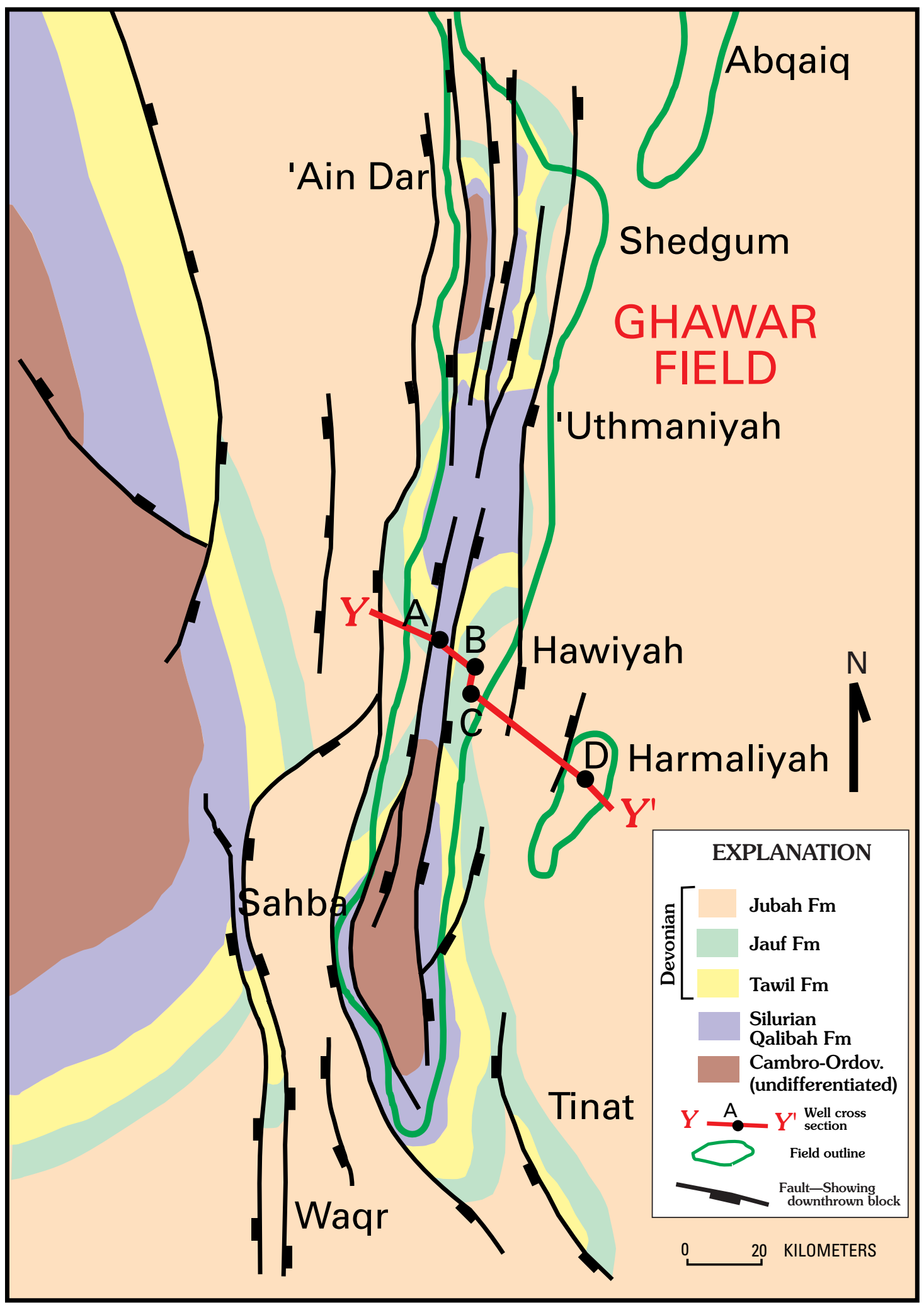

Figure 10. Geologic subcrop map of Hercynian or "Pre-Unayzah" unconformity showing differential erosion of both Hercynian substructures (such as 'Ain Dar, Shedgum) at Ghawar field and adjacent structures (Abqaiq, Waqr), Saudi Arabia. Well cross section for line $Y-Y^{\prime}$ shown in figure 11. Modified from Wender and others (1998). 


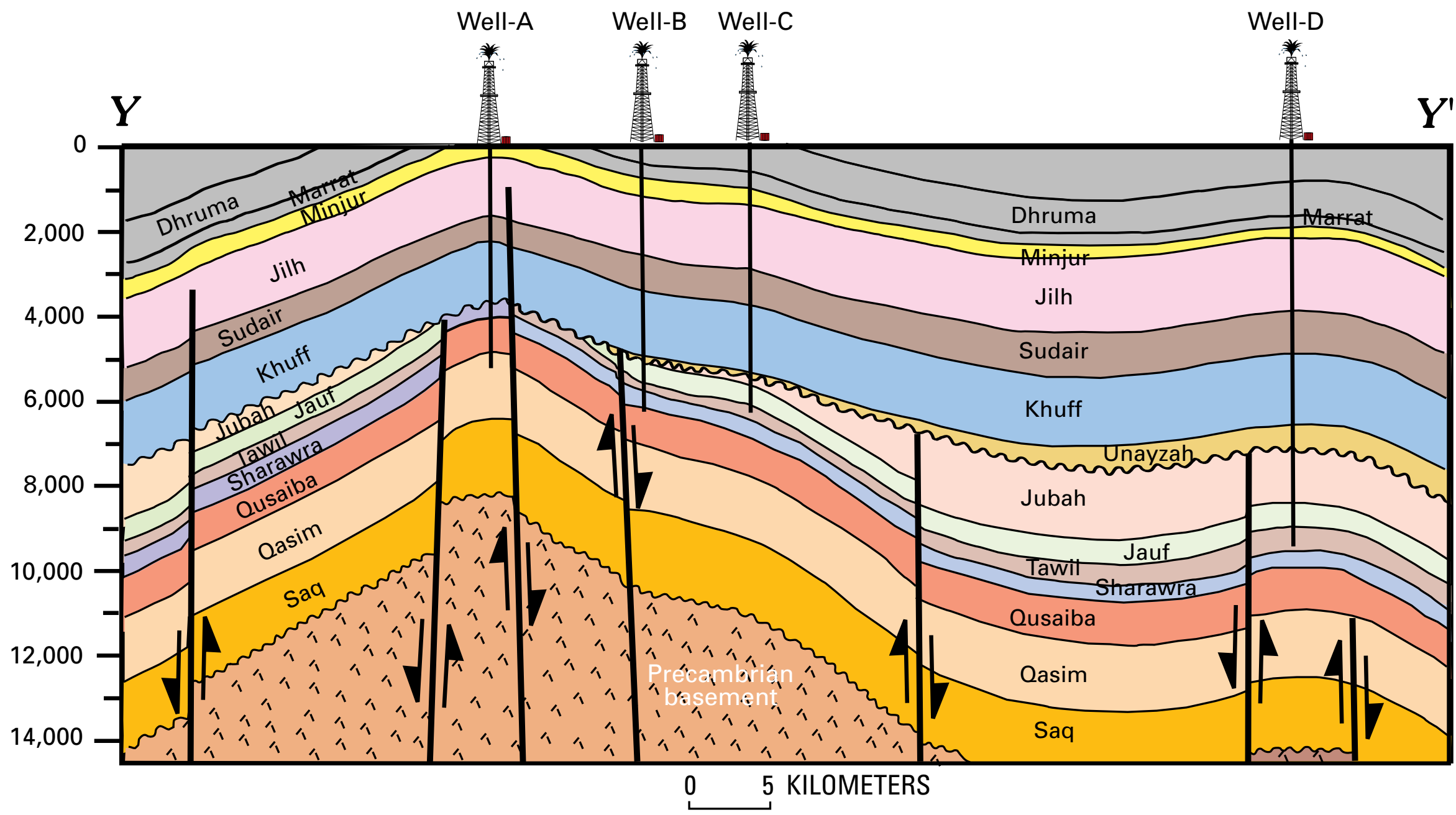

Figure 11. Structural cross section of central Ghawar field showing basement-involved block faulting and Hercynian growth for Middle Jurassic and older rocks. See figure 10 for location of cross section. Modified from Wender and others (1998). Barbs show relative movement on faults. 
regime to a prolonged phase of carbonate ramp and platform deposition with interspersed clastic episodes. During the Triassic, extensional faulting was widespread in response to thermal subsidence and stretching of the Arabian Plate. During this Early Zagros extensional event, earlier Hercynian structures were reactivated and enhanced. Rifting continued along the Zagros Suture and the Neo-Tethys Sea opened (figs. 3 and 8).

During the Late Triassic and Jurassic, the Arabian-Persian Gulf region was a stable interior platform located along the equator (Konert and others, 2001). A period of sea-level lowstand in the Early Jurassic is marked by a hiatus of nondeposition and erosion (fig. 1). Subsequent to this depositional hiatus, a transgression flooded the Arabian Peninsula and a shallow-marine, mostly carbonate platform developed. During the Middle and Late Jurassic, continued deposition of mostly carbonate and anhydrite beds occurred in warm equatorial latitudes. Sequence stratigraphic studies by Al-Husseini (1997) and Sharland and others (2001) show that cyclic changes in lithology (mostly carbonate/evaporite) of the Late Jurassic section (fig. 1) were due mainly to cyclic changes in relative sea level.

Three major post-Jurassic tectonic events were critical to major petroleum trap formation and modification that created the giant fields of the Paleozoic, Jurassic, and Cretaceous petroleum systems in the Central Arabian sub-basin (Wender and others, 1998). These major post-Jurassic tectonic events are (1) Early Triassic Zagros Rifting, (2) the First or Early Oman Alpine Orogeny, and (3) the Second or Late Alpine Orogeny (figs. 1 and 12). These tectonic events will be briefly discussed in a later section on trap formation.

\section{Stratigraphy of Central Saudi Arabia and Greater Ghawar Region}

\section{Pre-Khuff Section}

The stratigraphic section of Central Arabia and the Greater Ghawar Uplift Province is commonly divided into a "Pre-Khuff" and a "Khuff and younger" section (Wender and others, 1998). The Precambrian to Lower Cambrian basement rocks of Central Arabia are steeply dipping, fractured metasediments (figs. 1 and 13). Because the basement complex was subjected to north-south compression, subsequent rejuvenation of the dominant north-south structural elements also controlled the structural development of the sedimentary cover, and thus influenced the distribution of hydrocarbons in the Central Arabian sub-basin. The north-south orientation of major basement-involved structures, such as at Ghawar field, are easily identified on gravity maps where structural highs are generally associated with positive gravity anomalies (Wender and others, 1998).
The stratigraphic section varies in the onshore and offshore areas, as the Hormuz Salt is geographically limited to the Infracambrian rift basins that mostly underlie the offshore Gulf. The Late Permian to Early Triassic Khuff Formation is a thick formation consisting of cyclic anhydrite and carbonate rock that forms a regional seal for hydrocarbons (figs. 1 and 13). The Khuff is also locally a petroleum reservoir depending on the presence of dolomite and (or) the ratio of carbonate and anhydrite. Pre-Khuff (Cambrian to Late Permian) sediments in the Greater Ghawar area are composed of a massive sequence of siliciclastics ranging in thickness from about $2,450 \mathrm{~m}$ in the basinal areas to about $600 \mathrm{~m}$ on the crest of the Ghawar structure where significant erosion has occurred (figs. 1 and 13). The Pre-Khuff clastics were deposited in terrestrial to shallow-marine environments on the stable passive margin of Gondwana. Four erosional events have been recognized in the Paleozoic section of the Greater Ghawar area (Wender and others, 1998); however, the greatest amount of erosion was the result of uplift of the Arabian Plate associated with the Carboniferous Hercynian Orogeny. Variations in thickness of the Pre-Khuff section are due to broad epeirogenic uplifts of the Arabian Plate, creating intracratonic sag basins with intervening broad arches.

The first unmetamorphosed sedimentary rocks covering the Arabian Shield are the carbonates, clastics, and evaporites of Infracambrian age deposited within the rift salt basins (fig. 3). The Hormuz Salt (fig. 1) of the Hormuz Series of the Gulf is composed of massive salt, anhydrite, limestone, dark dolomite, and some red sandstone (Kent, 1970). The salt-bearing Infracambrian part of the stratigraphic section of the Arabian Plate is best represented by the Huqf Group of Oman. In Oman, the Huqf section has been partly exposed in two surface outcrops, and has been penetrated by deep drill cores. The massive salt of the Ara Formation of Oman is laterally equivalent to the Hormuz Series, and was probably its genetic continuation before major strike-slip faulting reshaped the margins of the rift basins. The salt of the Hormuz depositional megacycle occurs mostly in the offshore Gulf area (fig. 3 ), is as much as 2,500 m thick, and has produced numerous halokinetic structures (Edgell, 1991; 1996). In the area of Ghawar field, mostly Infracambrian clastics that have not yet been shown to contain hydrocarbons lie immediately above basement accretionary metasediments (fig. 13) (Wender and others, 1998).

The earliest post-Najd Rift sediments consist of arkosic sandstone and red micaceous siltstones of the Middle Cambrian to Early Ordovician Saq Formation (fig. 13). Although gas shows have been recorded in some sandstones of the Saq Formation, reservoirs are commonly of poor quality due to extensive silica cementation. A stacked sequence of shallowmarine micaceous sandstone and shale of the Middle to Late Ordovician Qasim Formation lies above the Saq Formation (Williams and others, 1986; King, 1995). In the southern Ghawar area, shale units grade into siltstone and shale due to epeirogenic uplift of the ancestral Central Arabian Arch (Wender and others, 1998). 


\begin{tabular}{|c|c|c|c|c|c|}
\hline $\begin{array}{l}\text { Structure/ } \\
\text { Field }\end{array}$ & $\begin{array}{l}\text { Carboni- } \\
\text { ferous } \\
\text { (Hercynian } \\
\text { Orogeny) }\end{array}$ & $\begin{array}{c}\text { Early } \\
\text { Triassic } \\
\text { (Zagros Rifting) }\end{array}$ & $\begin{array}{c}\text { Late } \\
\text { Cretaceous } \\
\text { (1st Alpine } \\
\text { Orogeny) }\end{array}$ & $\begin{array}{l}\text { Tertiary } \\
\text { (2nd Alpine } \\
\text { Orogeny) }\end{array}$ & $\begin{array}{c}\text { Gravity } \\
\text { anomaly }\end{array}$ \\
\hline ABQAIQ & & & & & None \\
\hline GHAWAR & & & & & Strong \\
\hline HARMALIYAH & & & & & Weak \\
\hline NIBAN & & & & & Strong \\
\hline SAHBA & & & & & Moderate \\
\hline TINAT & & & & & Moderate \\
\hline UDAYNAN & & & & & None \\
\hline WAOR & & & & & Moderate \\
\hline
\end{tabular}

Strong

Moderate

Weak

Figure 12. Growth history of major tectonic events and their relative intensities at various structures and substructures in Greater Ghawar area. Modified from Wender and others (1998).

During the early Paleozoic, Gondwana was at a high southern latitude such that glacial and other cold-climate systems were active. Glaciation during the Late Ordovician affected much of western Arabia, and much of the Ordovician section in central Arabia was deposited by glacial-fluvial meltwater from retreating ice (McGillivray and Husseini, 1992). During the advance and later retreat of these glacial systems, the Zarqa and the Sarah Formations (fig. 13) were deposited and represent a complex of glacial and periglacial sequences (Vaslet, 1987). Clean, fine- to medium-grained glaciogenic sandstones of the Sarah Formation represent a lowstand deposit associated with Gondwana glaciation in the Greater Ghawar area (Senalp and Al-Laboun, 1996). Sharland and others (2001) agreed with the interpretation of Sutcliffe and others (2000) that the Zarqa-Sarah sediment system represents subglacial valley systems, mostly above sea level, that were filled with sediment during ice sheet retreat. Although numerous gas shows have been reported from the Late Ordovician
Sarah Formation in the Ghawar area, no sustainable flow rates have been recorded there owing to low permeability (Wender and others, 1998).

Deglaciation during the Early Silurian caused a rise in sea level, which resulted in the widespread deposition of the upward-coarsening, progradational Qalibah Formation. The Qalibah Formation consists of a lower Qusaiba Member and an upper Sharawra Member (Husseini, 1991; Mahmoud and others, 1992) (fig. 13). Lower Silurian shales representing maximum flooding surfaces were deposited over most of the Gondwana passive margin shelf (Sharland and others, 2001), including the Middle East and Sahara. Regionally correlatable, organic-rich shale showing a distinctive high gamma-ray signature on logs persists at the base of the Qusaiba Member. This basal, high-gamma unit is referred to as the hot shale (fig. 13) and is considered the principal source rock for Paleozoic hydrocarbons in Saudi Arabia (Abu-Ali and others, 1991; Aoudeh and Al-Hajri, 1995; McGillivray and Husseini, 1992; 
Mahmoud and others, 1992; Cole, Abu Ali, and others, 1994; Bishop, 1995; Milner, 1998; Jones and Stump, 1999; Sharland and others, 2001).

Significant gas shows have been recorded in the "MidQusaiba Sand," an informal sandstone and siltstone unit within the Qusaiba Member. The Mid-Qusaiba Sand is commonly used as a marker bed and represents a progradational, basinfloor fan system related to the Silurian flooding event. The overlying Sharawra Member (fig. 13) consists of micaceous sandstones, siltstones, and shales, with some recorded gas shows; however, formation log analysis indicates that these are poor quality reservoirs (Wender and others, 1998). A hiatus is observed in the uppermost Early and Late Silurian in the Ghawar area where much of the uppermost part of the Silurian is missing, owing to nondeposition (Mahmoud and others, 1992).

Following the Silurian hiatus, fine- to medium-grained, fluvial to marginal marine, red-colored sandstones of the Late Silurian-Early Devonian Tawil Formation (fig. 13) were deposited along with thin, discontinuous beds of micaceous siltstone and shale (Wender and others, 1998). The Tawil clastics vary in thickness locally and are considered poor reservoirs because of extensive cementation by silica and kaolinite. In contrast, the overlying Early to Middle Devonian shallow marine sandstones of the Jauf Formation are of good reservoir quality. Overlying the Jauf Formation are very fine grained to medium-grained, poor reservoir quality sandstones of the Middle to Upper Devonian Jubah Formation (fig. 13).

An extensive period of erosion due to uplift in the early Carboniferous forms the Hercynian Unconformity (also referred to as the "pre-Unayzah Unconformity"). The Hercynian Unconformity is particularly evident throughout the stratigraphic section in the Greater Ghawar Uplift Province (fig. 13). For example, about $1,100 \mathrm{~m}$ of section was removed from the crestal portions of Ghawar field (Wender and others, 1998). Following the Hercynian Orogeny, middle Carboniferous to Early Permian fluvial and cold-climate dune sands of the Unayzah Formation were deposited. The basal Unayzah Formation consists of fine- to coarse-grained sandstones that filled relict, erosional topography (Al-Laboun, 1987). Glacial sediments, including cold-climate dune fields (Heine, in press), of the Lower Unayzah are also recognized in the south half of the eastern Arabian Peninsula from the southern part of the Greater Ghawar Uplift Province, into the Rub 'al Khali Basin Province, and also in Oman where the Lower Unayzah is equivalent to the glaciogenic Al-Khlata Formation (McClure, 1980; Hughes-Clark, 1988; Levell and others, 1988; Pollastro, 1999). The Unayzah Formation forms the principal pre-Khuff hydrocarbon reservoir in the south half of the Greater Ghawar area; however, the Unayzah is absent due to Hercynian erosion in the northern part of the Arabian sub-basin.

\section{Late Permian Through Jurassic}

During the Late Permian, following Unayzah deposition, a major marine transgression took place throughout the eastern Arabian Peninsula. The transgression coincided with Late
Permian rifting along the Zagros, opening of the Neo-Tethys Ocean, and deposition of the cyclic, dominantly shallow water carbonates and evaporites of the Late Permian to Lower Triassic Khuff Formation (Al-Jallal, 1989; 1995). The uppermost Khuff is of Early Triassic age. The Khuff ranges in thickness from 365 to 490 m over most of central and eastern Arabia, but thickens to more than $900 \mathrm{~m}$ in the Rub 'al Khali Basin (Al-Jallal, 1995) (figs. 1 and 13).

Transgressive sands and shales occur at the base of the Khuff Formation and are commonly referred to as the "basal Khuff clastics" or the Basal Khuff Formation. These basal clastics were deposited as channel and valley fill sediments on an incised Unayzah surface and were followed by the beginning of a significant marine transgression (McGillivray, 1994). Late Permian dolomites within the Khuff are major gas reservoirs, particularly along the offshore North Gulf north and west of Qatar. In contrast, the regionally extensive anhydrite, shale, and tight (low-permeability) carbonates of the Khuff Formation form the major regional seal for Pre-Khuff hydrocarbon accumulations in central and eastern Saudi Arabia (Al-Jallal, 1995; Wender and others, 1998).

The Triassic was a period of regional uplift (for example, Qatar Arch) and transgression (Alsharhan and Kendall, 1986). A stable Arabian Shield on the west and southwest of the Greater Arabian basin was the source of clastics that spread eastward. Following deposition of the Khuff, red beds of shale, interbedded with dolomite and evaporites of the Lower Triassic Sudair Formation, were formed on a flood-plain to lagoonal and tidal flat environment across Saudi Arabia (Sharief, 1986; Alsharhan and Nairn, 1997). The Sudair Shale is conformably overlain by a upward-coarsening sequence of the Middle Triassic Jilh Formation (fig. 1). The Jilh Formation displays a great diversity of siliciclastic and carbonate facies because it was deposited in a nonmarine (continental) and nearshore to shoreline complex (Sharief, 1986). Overlying the Jilh Formation are thick, continental, siliciclastic rocks of the Minjur Formation (fig. 11) that were deposited during regression and increased aridity. The Minjur was deposited over a broad area during the Late Triassic and is mostly medium grained, poorly sorted, crossbedded quartz sandstone with some conglomerate and shale lenses.

Throughout the Jurassic, the Arabian Plate was situated in the tropical or subtropical zone where the northeast passive margin of the Afro-Arabian Plate evolved as an extensive continental shelf (Murris, 1980; Beydoun, 1991). Deposition along the eastern Arabian Plate and Gulf during the Jurassic, and much of the Cretaceous, was characterized by platform carbonates. During most of the Early Jurassic, a pronounced, long-term, sea-level lowstand occurred from Early Zagros rifting and structural growth. This resulted in a period of nondeposition marked by a widespread Early Jurassic hiatus (fig. 1). During the Toarcian stage of the Early Jurassic, a widespread marine transgression caused by a major rise in relative sea level flooded the Arabian shelf, forming a shallow-marine platform. The Early and Middle Jurassic depositional environment of the central Arabian Plate and the Gulf area varied 


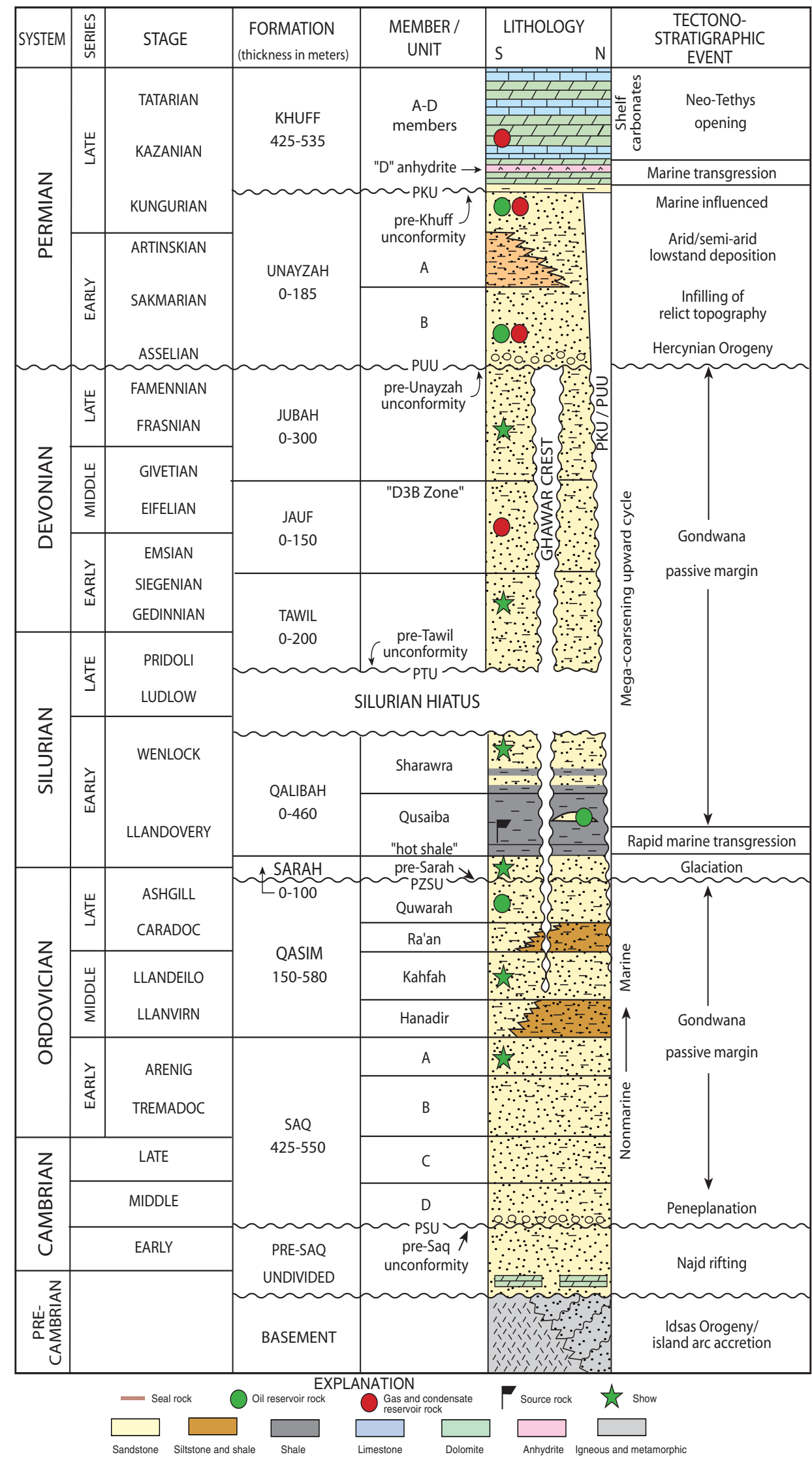

Figure 13. Stratigraphic column and tectonostratigraphic events of the Paleozoic section in Greater Ghawar area. Modified from Abu-Ali and others (1999; 2001). 
from nondeposition and erosion to an arid clastic platform in the west and to a shallow-marine, mostly carbonate platform on the north and east (Al-Husseini, 1997). This period is represented by the formation of basal shales, sandy shales, calcareous sandstones, limestones, and dolomites of the Dhruma and Marrat Formations (fig. 1). In the Jurassic Arabian sub-basin, the Dhruma is recognized as a minor source rock (Cole, Carrigan, and others, 1994), and the Marrat Formation contains some reservoir facies.

Differential subsidence within the shelf, combined with a relative increase in sea level, led to the formation of relatively short lived intraplatform sub-basins (Murris, 1980; Sharland and others, 2001; Zeigler, 2001). Three intraplatform subbasins existed in the Arabian-Persian Gulf region during the Late Jurassic (fig. 4) and were depocenters for sediments that formed the main Jurassic source rocks (Upper Jurassic Hanifa, Tuwaiq Mountain, and equivalents), as well as the sites of several important reservoirs. These source rocks and reservoir rocks together constitute the major Jurassic petroleum systems of the eastern Arabian Peninsula. The central Arabian intraplatform sub-basin of onshore east-central Saudi Arabia and adjacent offshore Gulf that formed in the late Middle Jurassic (late Callovian) and existed into the Late Jurassic (early Kimmeridgian) is the primary focus of this report. A deepwater intraplatform basin, the Gotnia sub-basin, existed in the northern Gulf region from Middle Jurassic to Early Cretaceous (Christenson and others, 1977; Murris, 1980; Ayres and others, 1982; Cole, Carrigan, and others, 1994; Al-Husseini, 1997; Zeigler, 2001). The Central Arabian sub-basin was separated structurally from the northern Gotnia sub-basin (fig. 4) by the Rimthan Arch (Langdon and Malacek, 1987). A third, smaller and shallower, intraplatform basin to the east, the South Arabian Gulf sub-basin, existed during the Late Jurassic (from late Oxfordian to early Kimmeridgian) and was separated from the Central Arabian sub-basin by the Qatar Arch (Murris, 1980; Alsharhan and Kendall, 1986; Droste, 1990) (fig. 4).

Cyclic changes in sea level during the Middle and Late Jurassic led to the development of a stacked series of shallowing-upward, carbonate platform sequences. The basinal facies consist of cycles of laminated, organic-rich, lime mud-wackestones. The thickest and most extensive Jurassic source-rock facies of central Arabia is the Tuwaiq Mountain Formation. It is considered the main Jurassic source rock of this region and was deposited in the southern part of the intraplatform Central Arabian sub-basin (fig. 4) between reservoir facies of the Dhruma (Fadhili zone) and Hanifa Formations (fig. 1). To the east and south of the Central Arabian sub-basin, organic-rich facies of the overlying Hanifa Formation form the major source rock for the Jurassic Hanifa/Diyab-Arab Total Petroleum System of the intraplatform South Arabian Gulf sub-basin (fig. 4) and within the greater Rub 'al Khali Basin proper. In the Central Arabian sub-basin, the organic-rich facies of the upper part of the Hanifa is of secondary significance compared to organic facies of the Tuwaiq Mountain (Cole, Carrigan, and others, 1994). Overlying the Hanifa Formation are dolomites and lime mudstones of the Jubailah Formation (fig. 1).
In the Late Jurassic, deposition of four carbonate-anhydrite cycles resulted in the four members of the Arab Formation in ascending order: Arab-D, C, and B, each consisting of a lower carbonate rock (grainstone) unit and an upper anhydrite unit, and the Arab A carbonate rock unit that is overlain by the Hith Anhydrite (figs. 1 and 14). The grainstone units of the Arab Formation comprise the most important petroleum reservoirs within the Central Arabian sub-basin and the countries of Saudi Arabia, Bahrain, and United Arab Emirates. The evaporite cycles within the Arab Formation provide the seals for the $\mathrm{B}, \mathrm{C}$, and D reservoirs. A thick sequence of evaporites, the Hith Anhydrite, immediately overlies the A Member carbonate rock of the Arab Formation, concludes the Jurassic depositional sequence in the area, and forms the principal regional seal to Jurassic-sourced hydrocarbons. McGuire and others (1993) and Sharland and others (2001) have correlated the Arab anhydrites to lowstand wedges and transgressive deposits, and the carbonate rocks to highstand deposits. Al-Husseini (1997) interpreted the Arab sequence as a late highstand of the Arab, Hith, and Gotnia evaporites.

In the Middle East, the Cretaceous stratigraphic section is normally divided into three parts, in contrast to the international two-part division. The "Middle" Cretaceous covers the time range from above the mid-Aptian unconformity to the uppermost Cenomanian-lower Turonian unconformity (Alsharhan and Nairn, 1988). During the Early Cretaceous (Berriasian), an intraplatform basin had again developed in central Arabia in which sediments forming the dark mudstones of the lower part of the Sulaiy Formation were deposited. Shelf grainstone carbonates then prograded from north to south over the lower Sulaiy. The overlying Yamama Formation represents the transition from intraplatform basin conditions to shelf sedimentation and the existence of a wide carbonate rock platform (Murris, 1980; Chaube and Al-Samahiji, 1995). Cyclic sedimentation of the Thamama Group shallow-shelf carbonates followed. By mid-Early Cretaceous (Barremian) time, a clastic regime occupied the west half of the basin pushing the carbonate ramp environment to the east (Murris, 1980). The Early Cretaceous Aptian was a period of renewed basin-wide inundation, and in late Aptian a shallow carbonate rock shelf spread westward over the previously deposited clastic rocks. On the fringing shelf margins, rudist reefs developed and formed the prolific hydrocarbon reservoirs of the Shu'aiba Formation (fig. 1).

Overlying the Thamama Group are shales, siltstones and fine-grained sandstones of the "Middle" Cretaceous Wasia Group (fig. 1). There is an obvious division of the Wasia Group into the lower, dominantly clastic units of the Nahr Umr Formation and upper, predominantly carbonate units (Powers, 1968). The lower clastic section is widely distributed over most of the Gulf area, where it consists of shale with subordinate limestones. Shales of the Nahr Umr Formation provide a good regional seal, and locally a hydrocarbon source rock, from Oman to Qatar. Farther to the west and northwest in Saudi Arabia, clastic units become more pronounced in the Wasia Group and are divided into the Safaniya and Khajfi Members (Alsharhan and Nairn, 1988; Christian, 1997). The upper, predominantly carbonate part of the Wasia Formation in Saudi Arabia is subdivided 


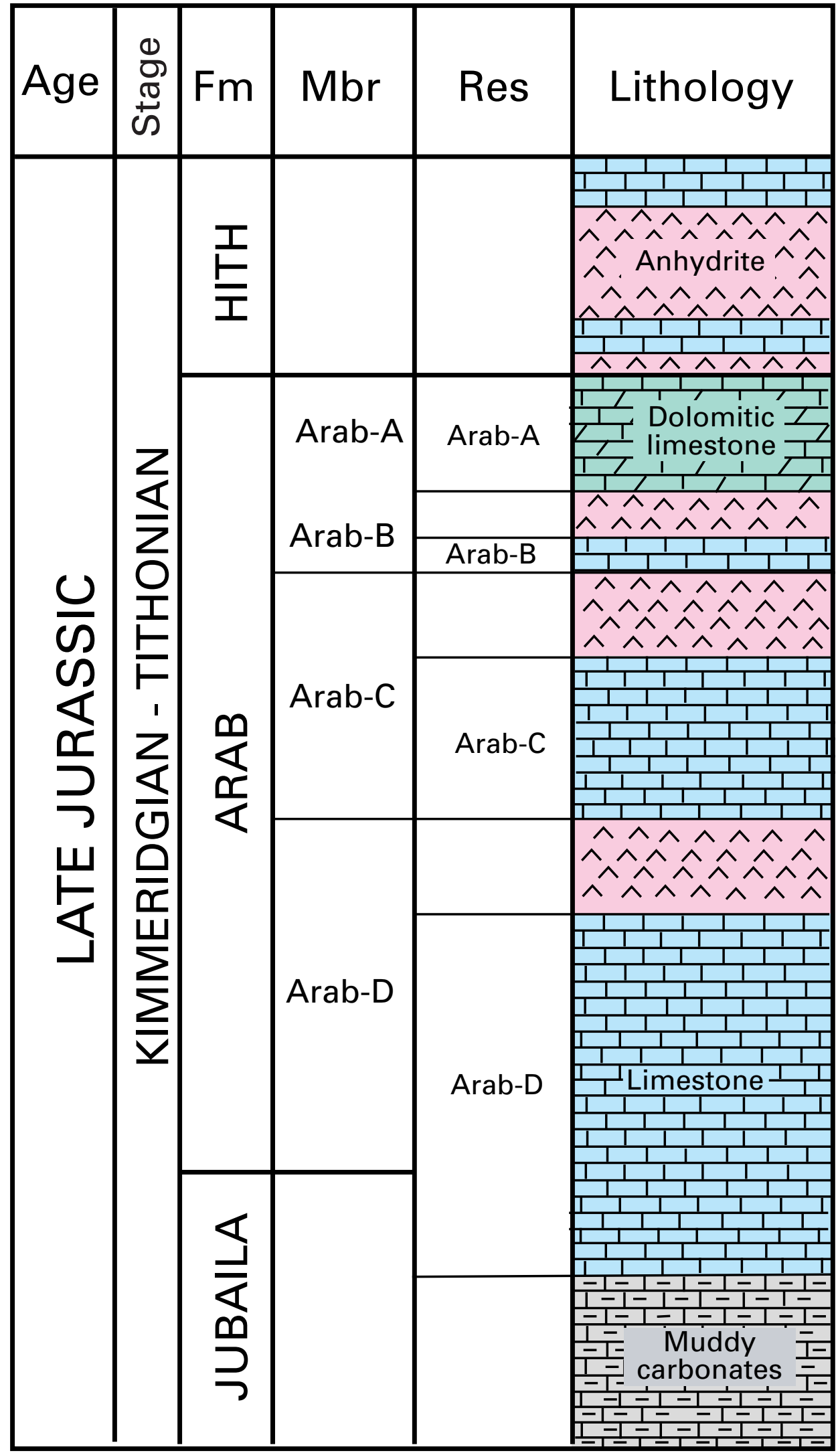

Figure 14. General stratigraphic section of the Upper Jurassic Arab Formation (Fm) showing stratigraphic units, lithology, intraformational reservoirs (Res) and seals (pink), and overlying and underlying units (Mbr, member). Modified from Hughes (1996). 
into four members in ascending order as follows: the Wara, Ahmadi, Rumaila, and Mishrif (fig. 1).

During the early Late Cretaceous, widespread clastics of the Aruma Group were deposited following a major erosional emergence in the Turonian. The lower Laffan and Halul Formations of the Aruma form a first transgressive cycle, whereas the Fiqa-Simsima cycle is more directly related to tectonic events (Alsharhan and Nairn, 1990). Sediments of the Aruma have variable thickness and lithofacies because they were the result of a complex response to (1) regional subsidence, (2) plate collision and partial subduction to the east, (3) eustatic sea-level fluctuations, and (4) differential sedimentation rates (Alsharhan and Nairn, 1990). In particular, many of the Hercynian faults bounding the major north-south uplifts in central Arabia were reactivated especially during the Late Cretaceous, as indicated by dramatic thickening of the Aruma Group on the flanks of these uplifts (Konert and others, 2001).

During the Paleocene and early Eocene, much of the eastern Arabian Plate was a wide, shallow carbonate and evaporitic platform in response to withdrawal to the south of the Neo-Tethys Sea. Rocks of Paleocene-Eocene age are generally calcareous with typical shallow-water lithologies. They vary in thickness, with a maximum-recorded thickness in the western part of about $330 \mathrm{~m}$; however, they are more than twice as thick to the east. In the foredeep toward the Zagros Mountains, these units increase in the amount of clastics they contain. Over southern Iraq, Kuwait, Saudi Arabia, Qatar, and United Arab Emirates, the shallow-water, Paleogene platform deposits generally are assigned to three formations of the Hasa Group, in ascending order the Umm Er Radhuma, Rus, and Dammam (fig. 1) (Alsharhan and Nairn, 1997).

Eastern Arabia underwent uplift and subaerial erosion from the Oligocene into the Miocene. The Oligocene through Pliocene (Neogene) of Saudi Arabia is composed of four formations totaling about $350 \mathrm{~m}$ in thickness, which in ascending order are the Hadrukh, Dam, Hofuf, and Kharj Formations. The early Miocene Hadrukh is mostly nonmarine sandy limestone and calcareous sandstone and is conformably overlain by marls, limestone, and claystones of the middle Miocene Dam Formation. The late Miocene-early Pliocene Hofuf Formation consists of marls, sandy limestones, conglomerates, and argillaceous sandstones of continental origin. The overlying Pliocene Kharj Formation consists of irregular-bedded limestone, sand, and gravel conglomerates, with some sediments indicating deposition in a freshwater, lacustrine environment (Alsharhan and Nairn, 1997).

\section{Central Arabia Qusaiba-Paleozoic Total Petroleum System}

\section{General Description}

The Central Arabia Qusaiba-Paleozoic TPS (202101) encompasses an area mostly within Saudi Arabia, Bahrain, western Qatar, and northern portions of the Gulf offshore within Iran along the Zagros Fold Belt (fig. 15). The Central Arabia Qusaiba-Paleozoic TPS includes all of the Greater
Ghawar Uplift Province and extends into the central part of the Interior Homocline-Central Arch Province (2020), the western flank of the Qatar Arch Province (2022), the northern flank edge of the Rub 'al Khali Basin Province (2019), the southeasternmost parts of the Widyan Basin-Interior Platform Province (2023), and the Mesopotamian Foredeep Basin (2024) Province (fig. 15).

The geographic boundaries of the Central Arabia Qusaiba-Paleozoic TPS were determined using several criteria, many of which are limited by the geographic extent of the source rock, or closely coincide with the geologic boundaries forming the Central Arabian intraplatform sub-basin (fig. 4). The western boundary of the Central Arabia Qusaiba-Paleozoic TPS (202101) is defined by the absence of the Qusaiba hot shale source facies along the Central Arabian Arch and Arabian Shield (fig. 3) due to Hercynian uplift and erosion (Bishop, 1995; Cole, Carrigan, and others, 1994; Milner, 1998; Abu-Ali and others, 1999; Jones and Stump, 1999; Konert and others, 2001). The TPS boundary is also limited to the north and west by the geographic extent of the Quisaiba hot shale, as interpreted by Mahmoud and others (1992), Bishop (1995), Jones and Stump (1999), and Konert and others (2001) (figs. 16, 17, and 18). Structural boundaries used in constructing the TPS boundary include (1) the western flank edge of the Rub 'al Khali Basin to the east and southeast; (2) the crestal axis of the Qatar Arch to the east and northeast; and (3) the Zagros Fold Belt to the north. Many of the oil and gas fields that produce from Paleozoic reservoirs, and that are assigned to the Central Arabia Qusaiba-Paleozoic TPS, are shown in figure 19 .

\section{Petroleum Geochemistry}

\section{Source Rocks}

An organic-rich shale facies of the Lower Silurian Qusaiba Member of the Qalibah Formation is the major source rock of the Central Arabia Qusaiba-Paleozoic TPS (Abu-Ali and others, 1991, 1999, 2001; Mahmoud and others, 1992; Cole, Carrigan, and others, 1994; Bishop, 1995; Milner, 1998; Jones and Stump, 1999; Sharland and others, 2001). Early Silurian deglaciation resulted in a major sea-level rise and the widespread deposition of the upward-coarsening, progradational Qalibah Formation. The Qalibah Formation accumulated in at least two rapidly subsiding regions along the eastern Arabian Peninsula (Jones and Stump, 1999).

The Qalibah Formation consists of a lower Qusaiba Shale Member, and upper sandstones, siltstones, and shale of the Sharawra Member (fig. 13). The Qusaiba Member is composed mostly of shale (mudstone) and thin interbeds of siltstone and sandstone; it is divided informally into upper and lower parts. On a regional basis, the lower Qusaiba is characteristically an upward-coarsening sequence, whereas the upper part of the Qusaiba is a fining-upward sequence (Jones and Stump, 1999). 


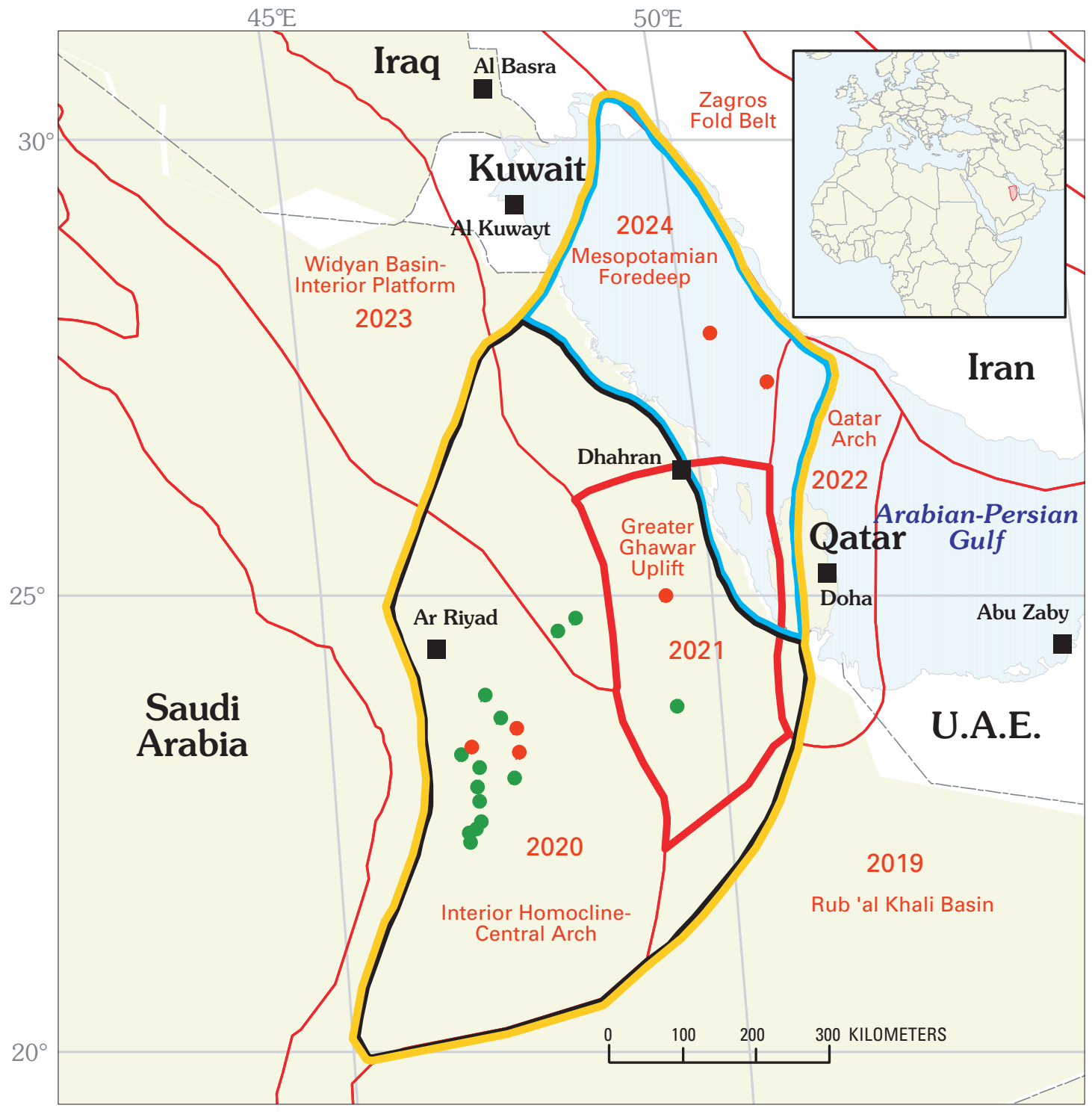

\section{EXPLANATION}

Central Arabia Qusaiba-

Paleozoic Total Petroleum System (202101)

Central Arch Horst-Block

Anticlinal Oil and Gas

Assessment Unit (20210101)

North Gulf Salt Basin Structural

Gas Assessment Unit (20210102)

Greater Ghawar Uplift

Province (2021)

2023 USGS province boundary and province number

Political boundary

- Oil field centerpoint

- Gas field centerpoint

- Major city

Figure 15. Greater Ghawar Uplift Province and adjacent geologic provinces, Central Arabia Qusaiba-Paleozoic Total Petroleum System, assessment units, and oil and gas field centerpoints in Central Arabian sub-basin of the Arabian-Persian Gulf. U.A.E., United Arab Emirates. 


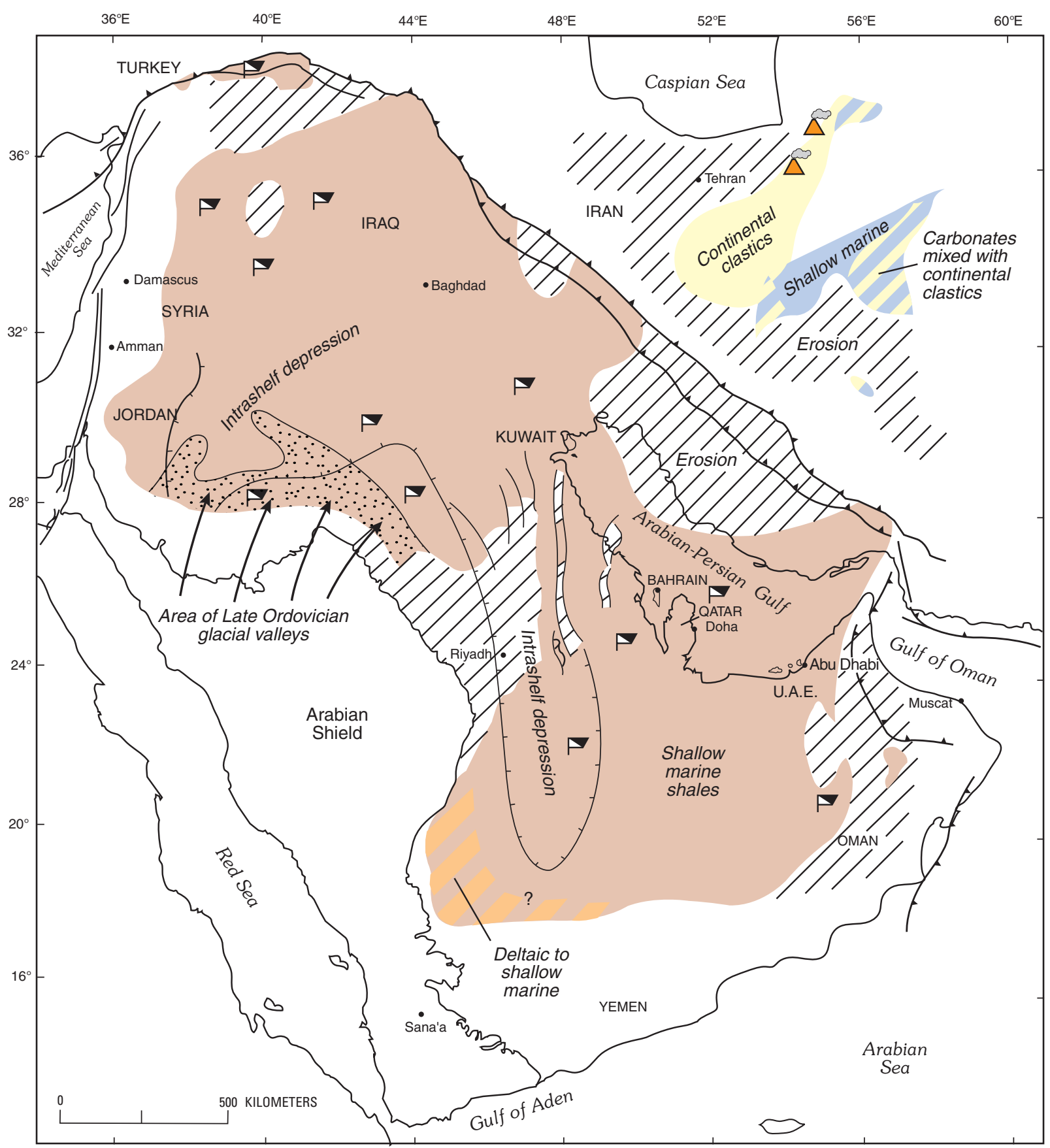

\section{EXPLANATION}

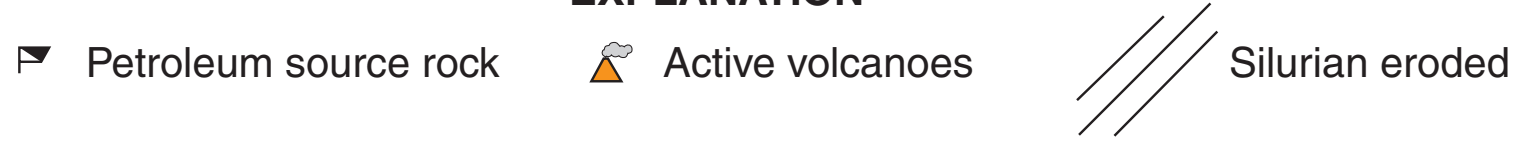

Figure 16. Paleoenvironmental map of the Early Silurian showing approximate extent of the Qusaiba Shale Member of the Qalibah Formation on Arabian Peninsula. Modified from Konert and others (2001). U.A.E., United Arab Emirates. 


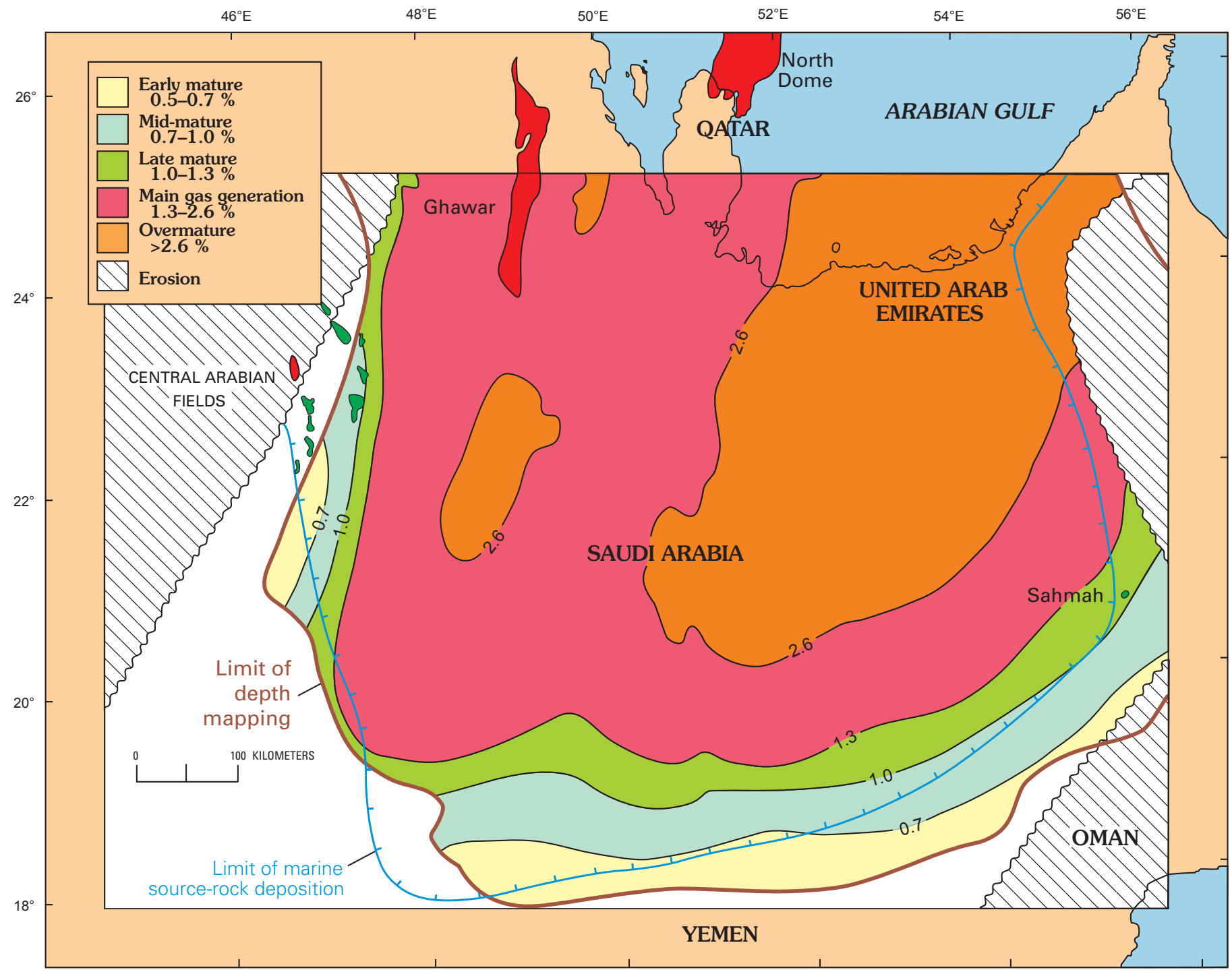

Figure 17. Central Arabia and Rub 'al Khali Basin showing depositional limit, present-day thermal maturity based on vitrinite reflectance (Ro), oil and gas fields producing from the Paleozoic, and eroded areas of the Silurian Qusaiba source-rock. Modified from Milner (1998). 


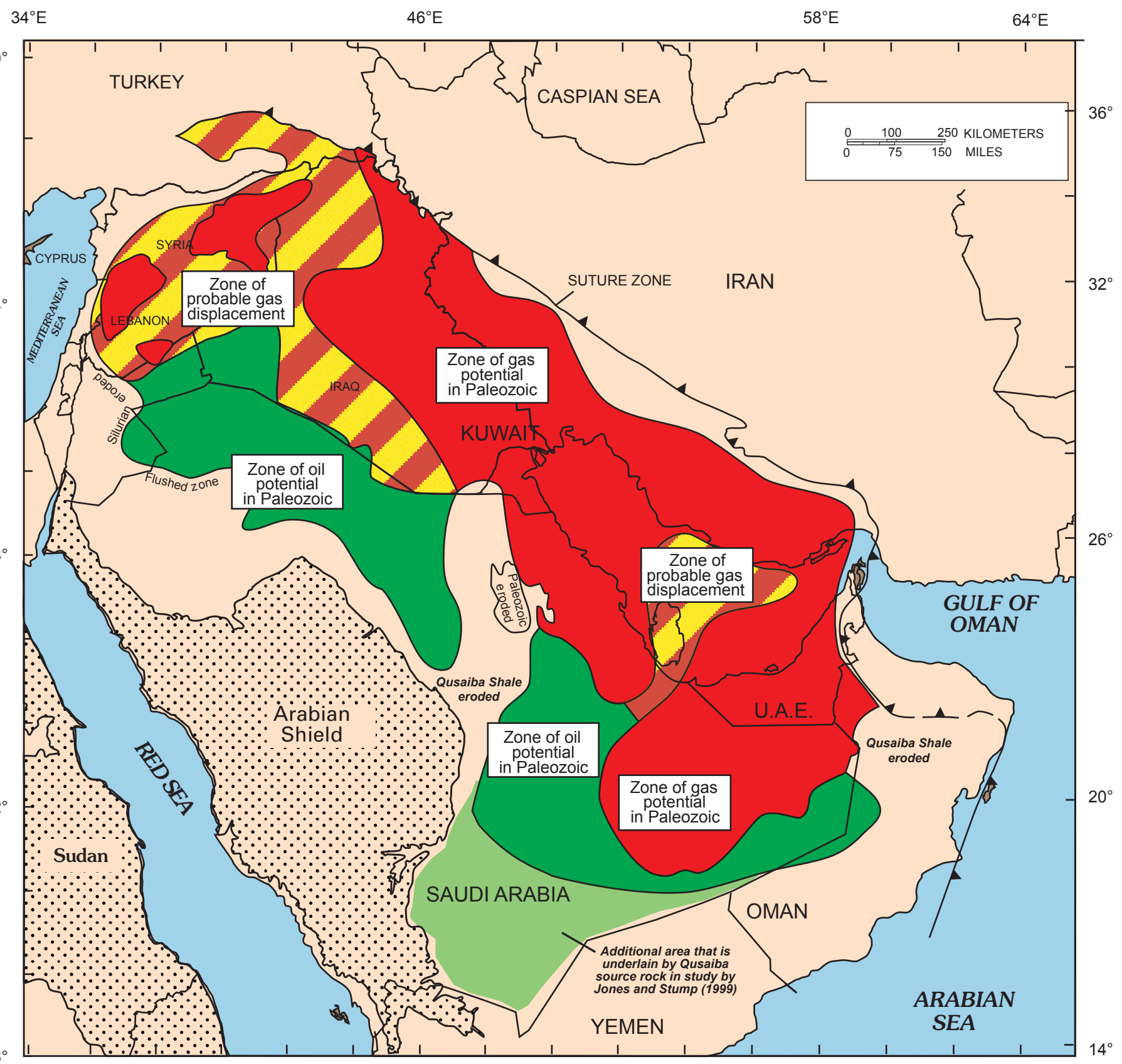

Figure 18. Geographic extent and present-day zones of hydrocarbon generation for Silurian Qusaiba Shale Member source facies, Arabian Peninsula. Modified from Bishop (1995) and Jones and Stump (1999). On suture zone, sawteeth on upthrown side. 
The base of the Qusaiba Member contains regionally correlative, organic-rich shale with a distinctive high gammaray signal on geophysical logs (fig. 20); this high gamma-ray interval is generally referred to as the hot shale. The lower, organic-rich part of the Qusaiba Member was deposited as a graptolitic sheet of mud on the middle to outer continental shelf. This depositional area of the Qusaiba included the greater part of the eastern Arabian Plate and North Africa during an extensive, rapid and regional transgression as a consequence of deglaciation. The basal hot shale of the Qusaiba Member is the principal source rock for Paleozoic hydrocarbons along the eastern Arabian Peninsula (Beydoun, 1991; Husseini, 1991; Mahmoud and others, 1992; McGillivray and Husseini, 1992; Abu-Ali and others, 1991; 1999; Bishop, 1995; Milner, 1998; Jones and Stump, 1999). Four total petroleum systems have been identified along the eastern Arabian Plate and Zagros Fold Belt; the Qusaiba Member is their source rock and their reservoirs are of Paleozoic age (Ahlbrandt and others, 2000; Pollastro and others, 2002).

The Lower Silurian basal Qusaiba Member hot shale is a dark-gray to black, commonly microlaminated, euxinic shale with as much as 20 weight percent total organic carbon (TOC). The hot shale averages about 3-5 weight percent TOC in Saudi Arabia (Abu-Ali and others, 1991; 1999; Cole, Abu-Ali, and others, 1994; Jones and Stump, 1999) and 6 weight percent in Iraq (Aqrawi, 1998). The basal hot shale maintains good to excellent TOC whether in an immature setting or a mature setting (Cole, Abu-Ali, and others, 1994). Jones and Stump (1999) suggested that rapid transgression of the Qalibah Formation caused displacement of earlier shallowmarine coarse clastics, allowing organic matter to accumulate undiluted on the continental shelf of northern Gondwana. Sharland and others (2001) interpreted deposition of the hot shale facies as a condensed sequence on a sediment-starved continental shelf and determined that the hot shale facies is a maximum flooding surface.

The organic-rich, basal hot shale of the Qusaiba Member is best developed in the subsurface of eastern-central Saudi Arabia and lies immediately above a basal sandstone that varies in thickness between 1 and $30 \mathrm{~m}$. The hot shale has been reported to be as much as $75 \mathrm{~m}$ in thickness, but commonly is about 9-31 m thick (Cole, Abu-Ali, and others, 1994; Jones and Stump, 1999). Locally, the Qusaiba Member is absent owing to uplift and erosion during the Late Devonian to Carboniferous Hercynian Orogeny (figs. 16 and 18).

Jones and Stump (1999) suggested that the hot shale of the Qusaiba Member should contain greater than 2.0 percent TOC to be considered a source bed. They calibrated TOC of the Qusaiba Member to gamma-ray response in API units and found that $150 \mathrm{API}$ units corresponds favorably to greater than 2.0 percent TOC (fig. 20). Mapping of the hot shale using the greater than 150 API unit log signature by Jones and Stump (1999) showed that the thickest and richest source rock of the Qusaiba occurs on the flanks of depocenters, rather than within the depocenters as previously reported by Mahmoud and others (1992) and Cole, Abu-Ali, and others (1994). Jones and Stump suggested that the hot shale was likely deposited in an essentially uniform thickness and subsequently reworked and eroded by turbidites that preferentially moved down the axes of the Qusaiba depocenters. Mapping of the hot shale by Stump and van der Eem (1995) and Jones and Stump (1999) showed that the areal extent of favorable Qusaiba Member source rock is much greater, particularly in the Rub 'al Khali Basin, than previously shown in studies by Mahmoud and others (1992), Cole, Abu-Ali, and others (1994), Bishop (1995), and Milner (1998).

\section{Organic Geochemistry}

Oil-oil and oil-source rock correlations by Abu-Ali and others (1991) and Cole, Abu-Ali, and others (1994) show that oil and condensates from Paleozoic reservoirs of Saudi Arabia have been generated from a common source- the basal Qusaiba Member hot shale. Oil-to-source rock correlations show a high degree of similarity in biomarker distribution between extracted bitumen and oils, and an excellent isotopic compatibility between extracted kerogen and oils (Mahmoud and others, 1992). Organic material in the basal Qusaiba Member hot shale consists mostly of oil-prone Type II (amorphous marine algae) kerogens with abundant chitinozoans and graptolites.

Paleozoic oils derived from clastic Qusaiba Member source beds are geochemically much different from and more mature than those generated from younger, carbonate source beds of Jurassic and Cretaceous age. The Paleozoic-sourced oils have lighter API gravities and lower sulfur and trace-metal contents (Abu-Ali and others, 1991). API gravities of Paleozoic oil range from $40^{\circ}$ to $53^{\circ}$ (fig. 19), whereas Mesozoic oils are commonly in the range of $20^{\circ}-40^{\circ}$. Sulfur content of oils from the Qusaiba shale is less than 0.1 weight percent. In contrast, oils from Jurassic carbonate source rocks are commonly greater than 1.0 weight percent sulfur. Qusaiba-derived oils have an average $\delta^{13} \mathrm{C}$ isotope ratio of $-29.8 \%$ relative to the PDB standard, and Mesozoic oils are isotopically heavier, averaging $-26.5 \%$ (Abu-Ali and others, 1991).

\section{Maturation, Generation, and Expulsion}

Several studies have modeled the thermal maturation of the basal Qusaiba Member hot shale along the eastern Arabian Plate (Abu-Ali and others, 1991; 1999; 2001; Mahmoud and others, 1992; Cole, Abu-Ali, and others, 1994; Bishop, 1995; Milner, 1998; Jones and Stump, 1999). Figure 17 summarizes the thermal maturity of the Qusaiba Member source rock for the Central Arabia Qusaiba-Paleozoic TPS. Also, figure 18 shows present-day geographic zones of oil and gas generation. Hydrocarbon maturation and generation for the Central Arabia Qusaiba-Paleozoic TPS are also summarized in the total petroleum system events chart of figure 21 , and in the burial history and hydrocarbon expulsion history of figure 22 and figure 23 . 


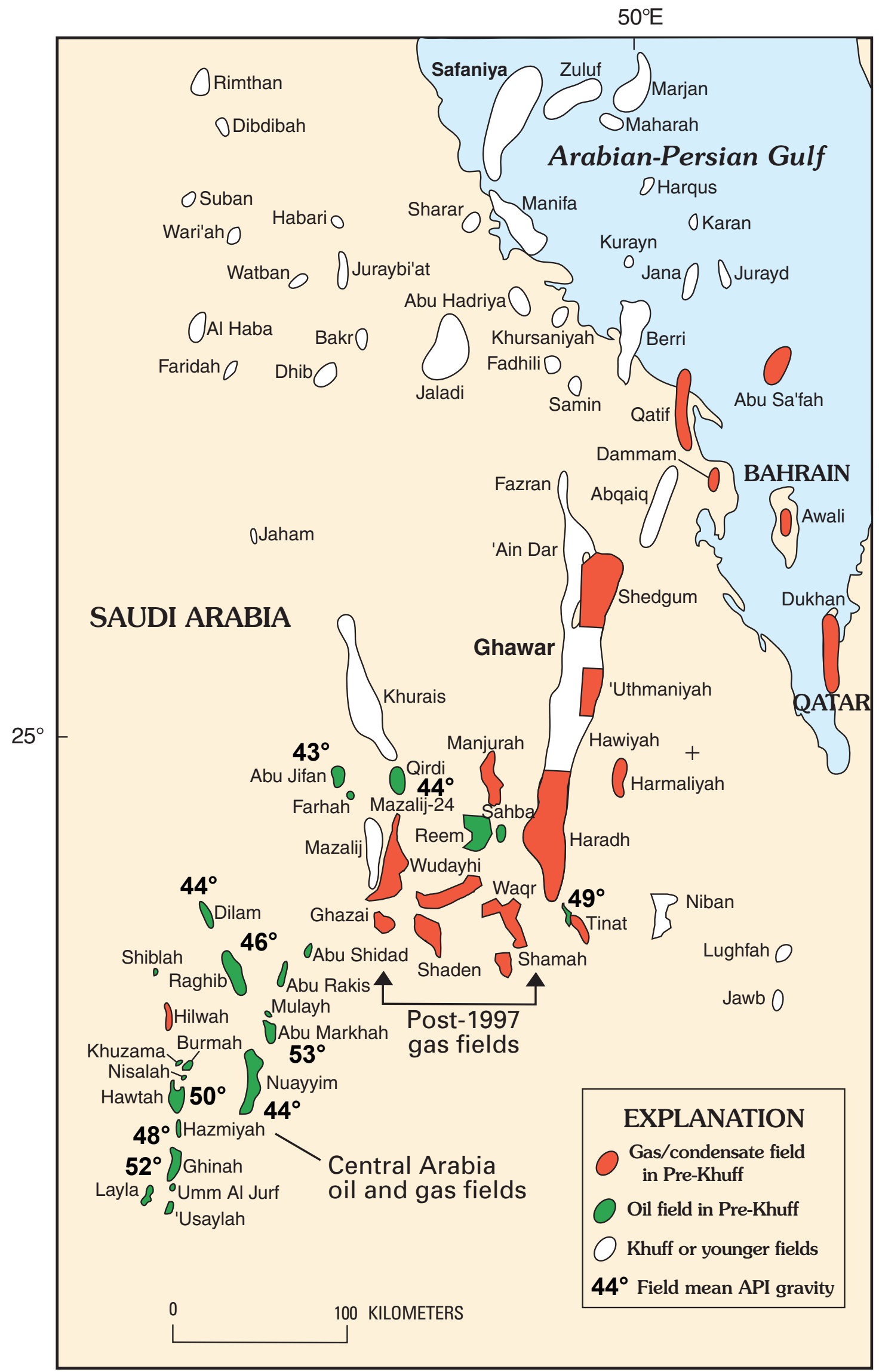




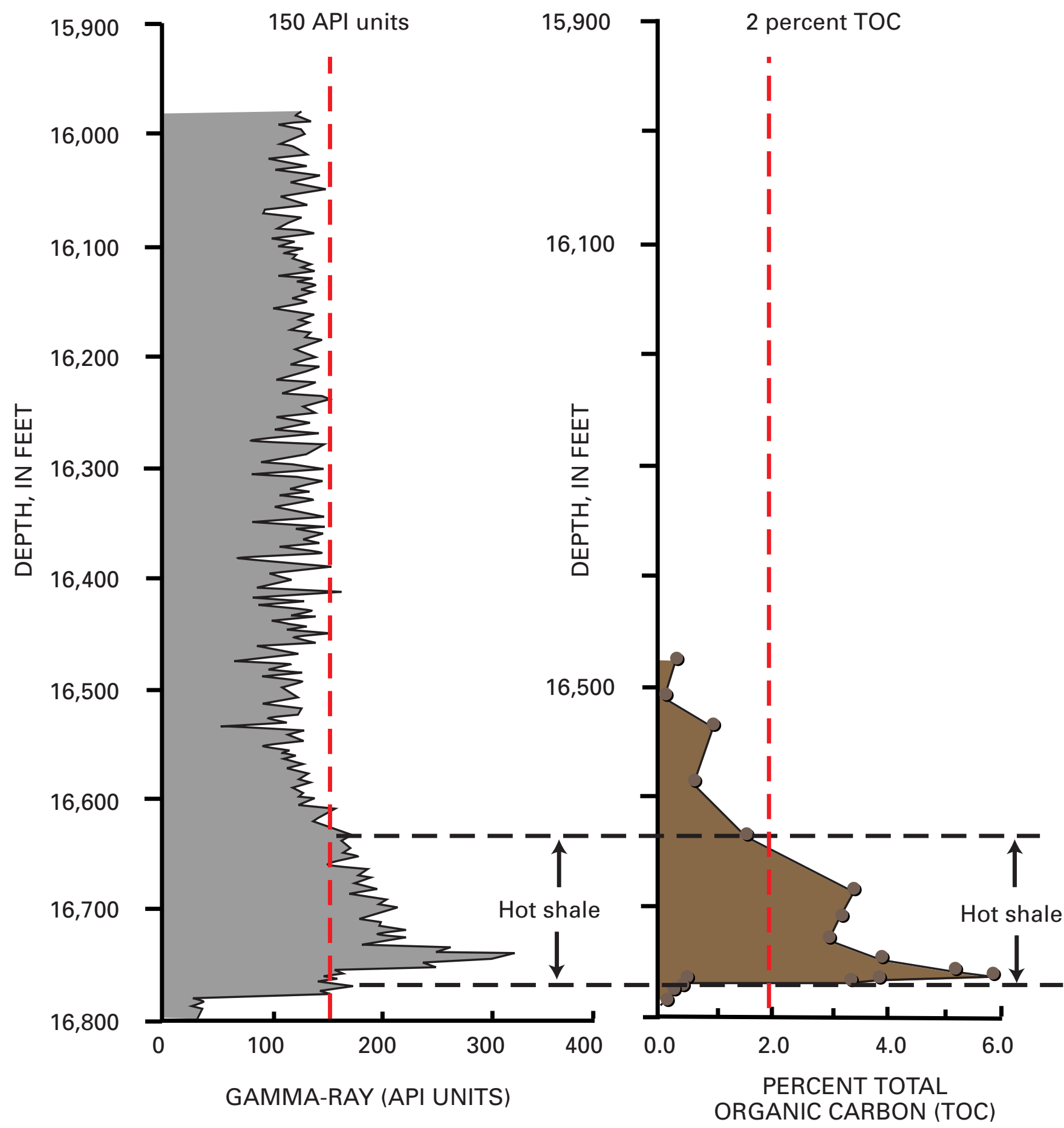

Figure 20. Relation between gamma-ray response versus total organic carbon (TOC) in transitional-type, basal hot shale of lower Qusaiba Member source rock, Qalibah Formation. Gamma-ray response of 150 API units closely corresponds to about 2 weight percent TOC. Modified from Jones and Stump (1999).

Figure 19 (preceding page). Outlines, names, mean field API gravities, and general locations of oil and gas fields in central Saudi Arabia and northern Arabian-Persian Gulf producing from Pre-Khuff and Khuff or younger formations. Modified from AbuAli and others (1999), Al-Husseini (1997), and McGillivray (1994). 


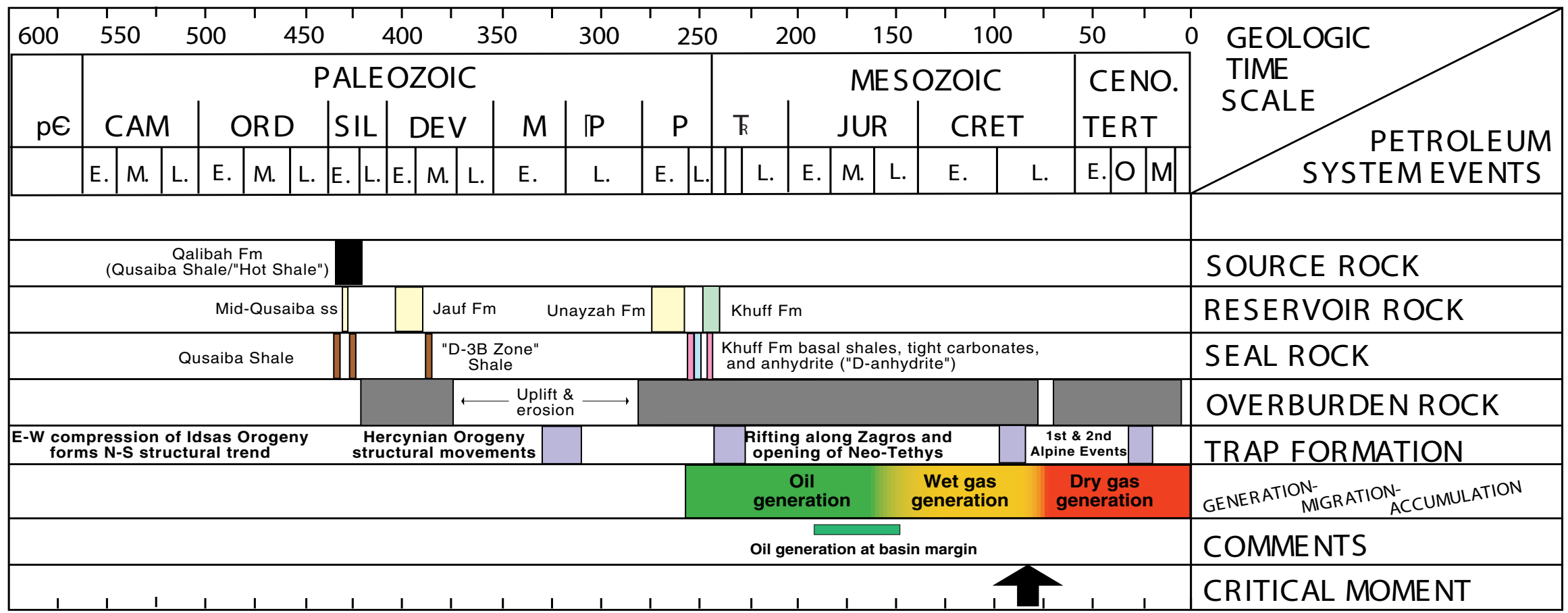

\section{Late structural growth/fault reactivation}

forming traps subsequent to gas generation

Figure 21. Total petroleum system events chart for Central Arabia Qusaiba-Paleozoic Total Petroleum System (202101) of the Greater Ghawar Uplift Province (2021) and surrounding geologic provinces of central Saudi Arabia, showing total petroleum system elements and timing of trap formation and hydrocarbon generation. 
Cole, Abu Ali, and others (1994) showed that present-day maturity, as expressed in $R_{0}$, at the base of the Qusaiba generally increases from less than 0.5 percent along the exposed western rim of the basin in central Saudi Arabia, eastward to thermally mature oil generation and expulsion of greater than 0.7 percent, to mature for gas at greater than 1.3 percent, and finally into areas further to the east of greater than 2.0 percent where the Qusaiba is considered spent as a hydrocarbon source. Based on the present-day thermal maturity trend of the Qusaiba, and the maturity of oils analyzed from fields in central Saudi Arabia, they concluded that most oils in these fields migrated long distances. The present-day maturity of the Qusaiba in the vicinity of the oil fields is insufficient for the generation of oil, whereas the API gravities of oils in these fields range from $40^{\circ}$ to $53^{\circ}$. Therefore, oils in the central Arabian fields migrated westerly from downdip and deeper, eastern "kitchens" where the Qusaiba source rock is thicker and thermally mature for oil (fig. 24). Moreover, the excellent seal capacity provided by the overlying Khuff evaporites and carbonates contributes to the efficiency of migration and containment of the petroleum system. Burial-history models for the Qusaiba Member source rock at locations near the basin margin and deep basin are shown in figure 22 and figure 23.

Bishop (1995) calculated maturation and geohistory curves of the Lower Silurian Qusaiba source rock and published maps showing present-day level of thermal maturity, time of onset of significant oil and gas generation, and expected hydrocarbon type for the eastern Arabian Peninsula (fig. 18). Bishop (1995) concluded that present-day thermal maturities of the lower Qusaiba range from immature to overmature (exhausted) over the eastern Arabian Peninsula, and that charging of traps with oil, and then gas, from the Qusaiba probably began during the Triassic in the South Gulf Salt Basin (fig. 3) and progressed southward into the Rub 'al Khali Basin during the Cretaceous. Maturation and generation of Silurian source rocks largely ceased in the early Tertiary, but maturation and generation were reactivated by the Zagros collision in the Miocene and may be continuing into the present day.

Cretaceous, Jurassic, and Silurian source rocks of the southern Arabian Peninsula were analyzed by Milner (1998) for both source-rock richness (Rock-Eval analysis) and thermal maturity (as determined by vitrinite reflectance). Milner then used regional geologic and structural framework data, combined with heat flow and source-rock quality data, to construct burial-history models and map the geographic extent of the source facies and maturity stages (fig. 17). With the exception of the Paleozoic oil and gas fields of central Saudi Arabia, maturity modeling of Silurian-sourced hydrocarbons was verified by (1) location of Paleozoic oil fields (for example, Sahmah field, Oman) within mapped levels of thermal maturity $\left(\mathrm{R}_{\mathrm{o}}\right)$ for oil generation, and (2) occurrence of Paleozoic gas fields (such as Ghawar, Saudi Arabia, and North field, Qatar) within the mapped level of thermal maturity for gas generation (figs. 17 and 25). Oil fields of central Saudi Arabia that produce Silurian-sourced, super-light (about $50^{\circ}$ API gravity) sweet crude oil lie about $60 \mathrm{~km}$ from a level of maturity indicative of late oil generation. As mentioned previously, oils within these fields are believed to have migrated long distances, westward and updip, from an eastern, more mature source area, and into traps along the basin monocline adjacent to the Arabian Shield (fig. 24) (McGillivray and Husseini, 1992; McGillivray, 1994; Cole, Carrigan, and others, 1994).

Jones and Stump (1999) found that the Qusaiba Member source-rock facies is gas prone to gas-condensate prone near the axis of the Qalibah trough depocenter, and more oil prone east and south of the depocenter. The Qusaiba is overmature with respect to oil generation over most of the Central Arabian sub-basin, South Arabian Gulf sub-basin, and Rub 'al Khali Basin (figs. 17 and 18). Moreover, in a comparison of the areal extent of the hot shale in the Central Arabian sub-basin, Rub 'al Khali Basin, and South Arabian Gulf sub-basin, Jones and Stump (1999) found that the Qusaiba Member source-rock facies extends beyond previously published interpretations by Mahmoud and others (1992), Cole, Abu-Ali, and others (1994), and Milner (1998), thus expanding the prospective area for Paleozoic hydrocarbon generation and accumulation (fig. 18).

An integrated study of the generation and expulsion of oil and gas from the Qusaiba Member hot shale by Abu-Ali and others $(1999 ; 2001)$ has provided further insight into the Central Arabia Qusaiba-Paleozoic TPS. In their study, compositional kinetic experiments from control samples were combined with a set of historical maps to model the stages of source-rock maturation, and petroleum generation and expulsion. Actual and hypothetical wells were used to calibrate their model and document hydrocarbon expulsion history from different locations in the basin. They found that expulsion of oil and gas was limited to a small region in the southeastern part of the Central Arabian sub-basin (fig. 25). In the deepest part of the Central Arabian sub-basin, the Qusaiba source rock was thermally mature by the Late Jurassic, but hydrocarbon expulsion was not initiated until the Early Cretaceous (fig. 23). Oil and gas were expelled simultaneously, but gas expulsion continued for a longer time period. Most of the gas was expelled during the Late Cretaceous; expulsion of oil nearly ceased after the Late Cretaceous. Oil and gas expulsion are linked to three events: (1) primary kerogen cracking, causing the first episode of expulsion about $120 \mathrm{Ma}$; (2) secondary cracking of heavy components and oils, causing a second episode of expulsion at about $100 \mathrm{Ma}$; and (3) a later uplift and erosional event, resulting in a third pulse of expulsion at about 20-10 Ma during which the gas was separated from the oil, causing re-migration.

In this report, the combined studies of Abu-Ali and others (1991; 1999; 2001), Mahmoud and others (1992), Cole, AbuAli, and others (1994), Bishop (1995), Milner (1998), and Jones and Stump (1999), were used to construct the "pod of active source rock" for the Central Arabia Qusaiba-Paleozoic TPS, shown in figure 26. 


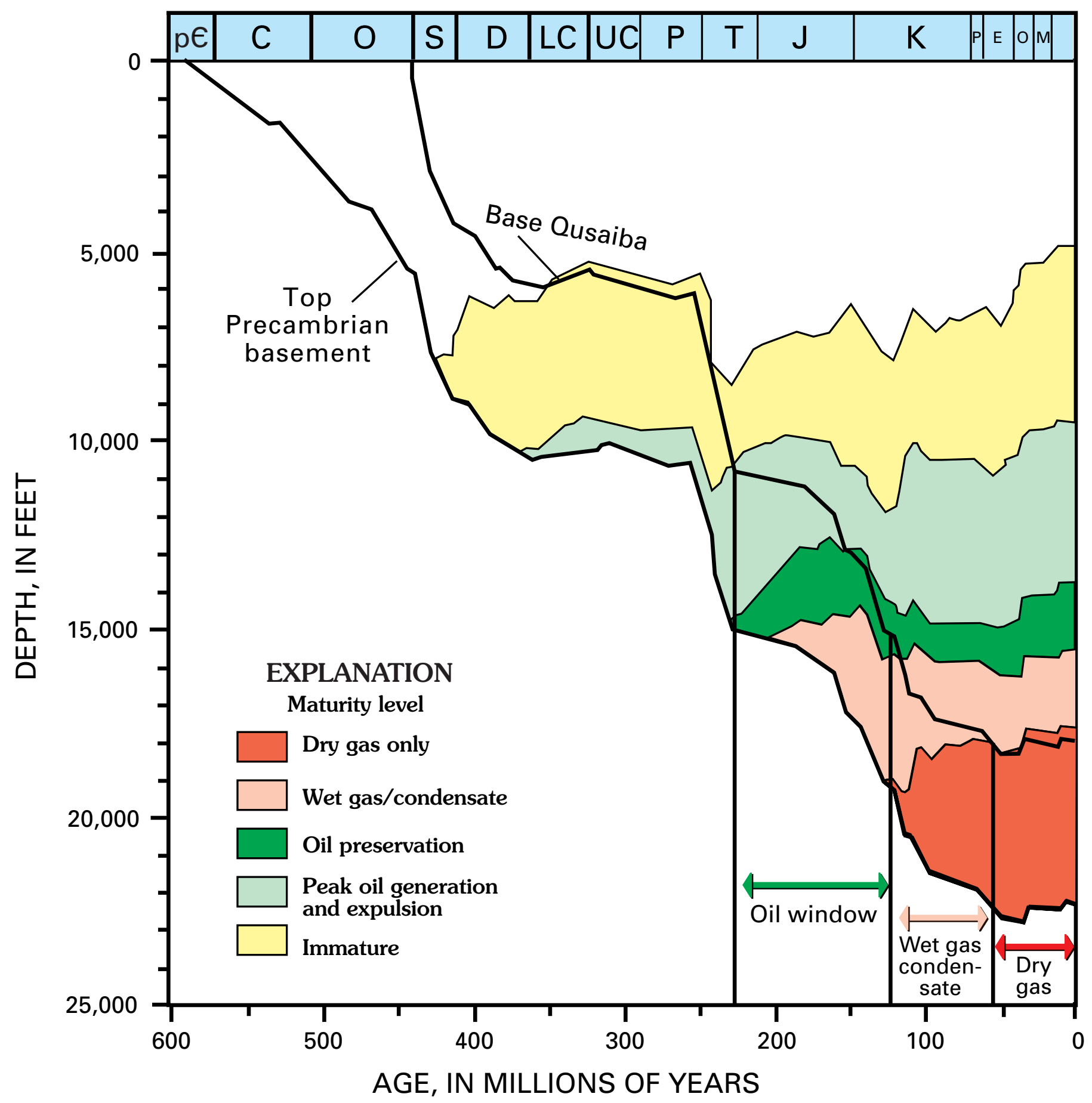

Figure 22. Burial history and hydrocarbon generation model for base of the Silurian Qusaiba Member source rock in Udaynan well, Saudi Arabia. Well location shown in figure 25. Modified from Wender and others (1998). 


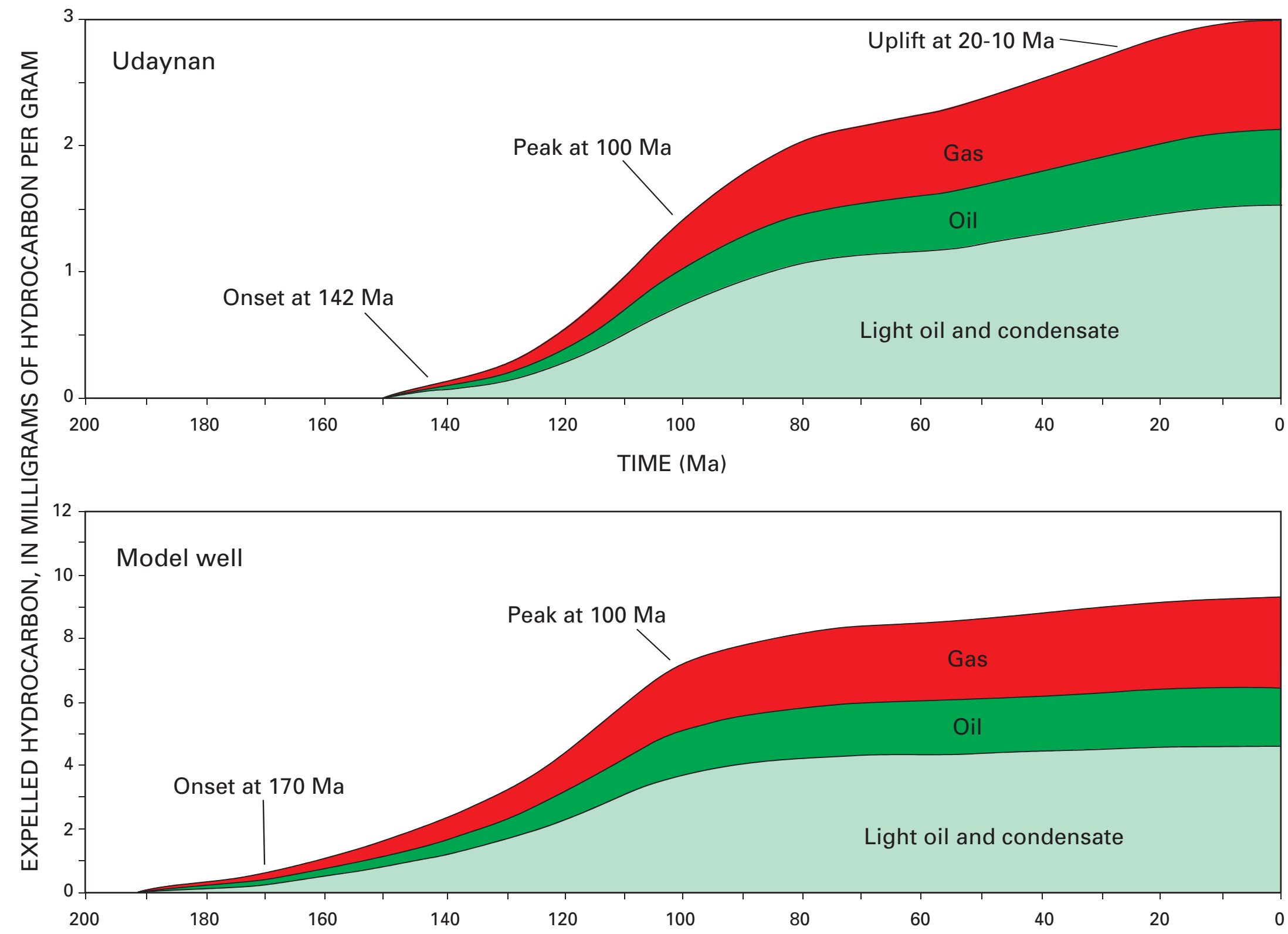

Figure 23. Hydrocarbon expulsion history from the Qusaiba Member source rock as modeled in Udaynan well and in hypothetical Model well about 30 km to the southeast in deepest part of kitchen. Well locations shown in figure 25. Modified from Abu-Ali and others (1999). 


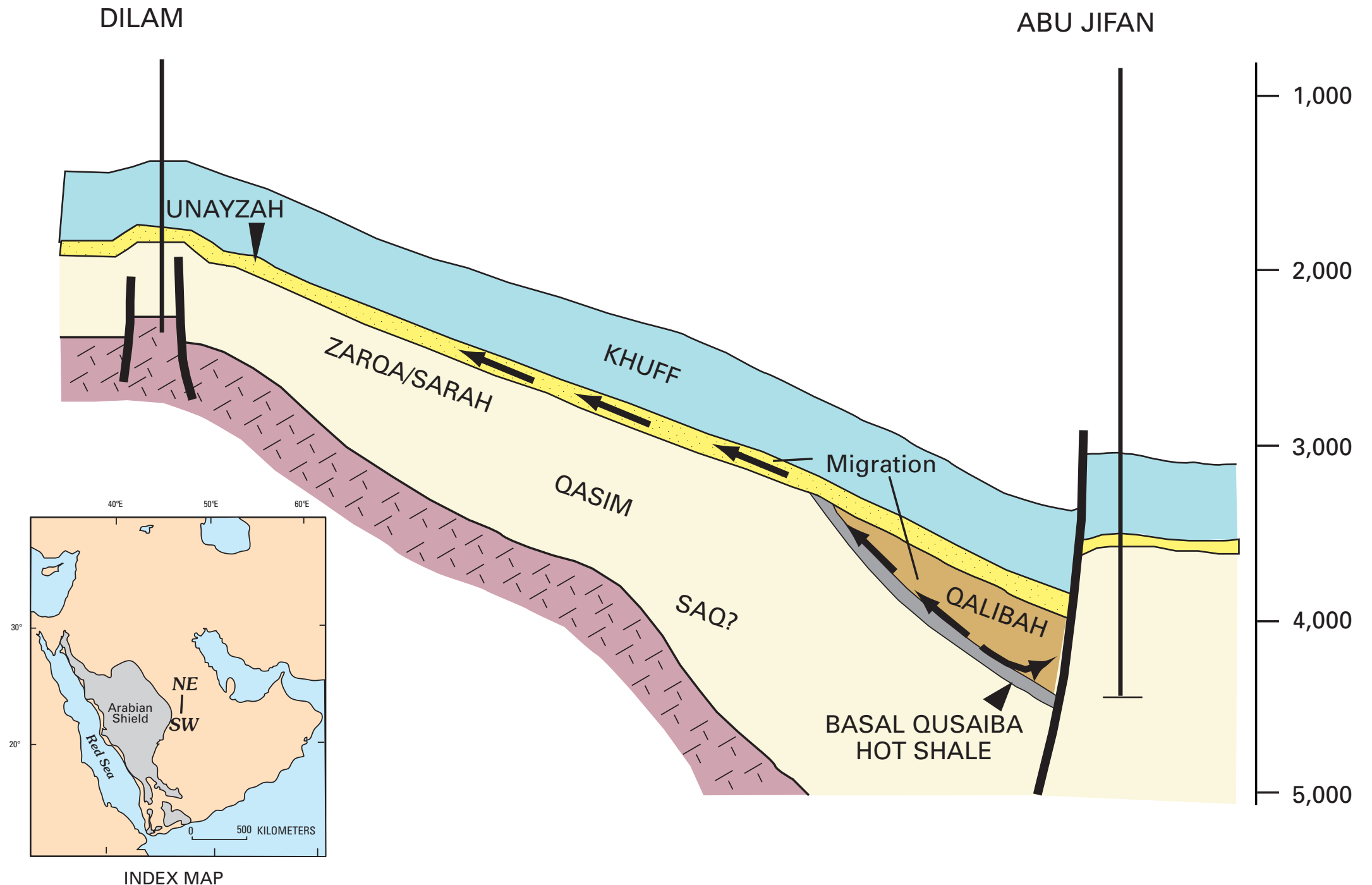

Figure 24. Generalized Khuff and Pre-Khuff section along basin monocline from Dilam field to Abu Jifan field, Saudi Arabia (see fig. 25), showing regional updip hydrocarbon migration from mature Qusaiba Member source rock near Abu Jifan field into Unayzah reservoirs at Dilam. Modified from McGillivray (1994). 


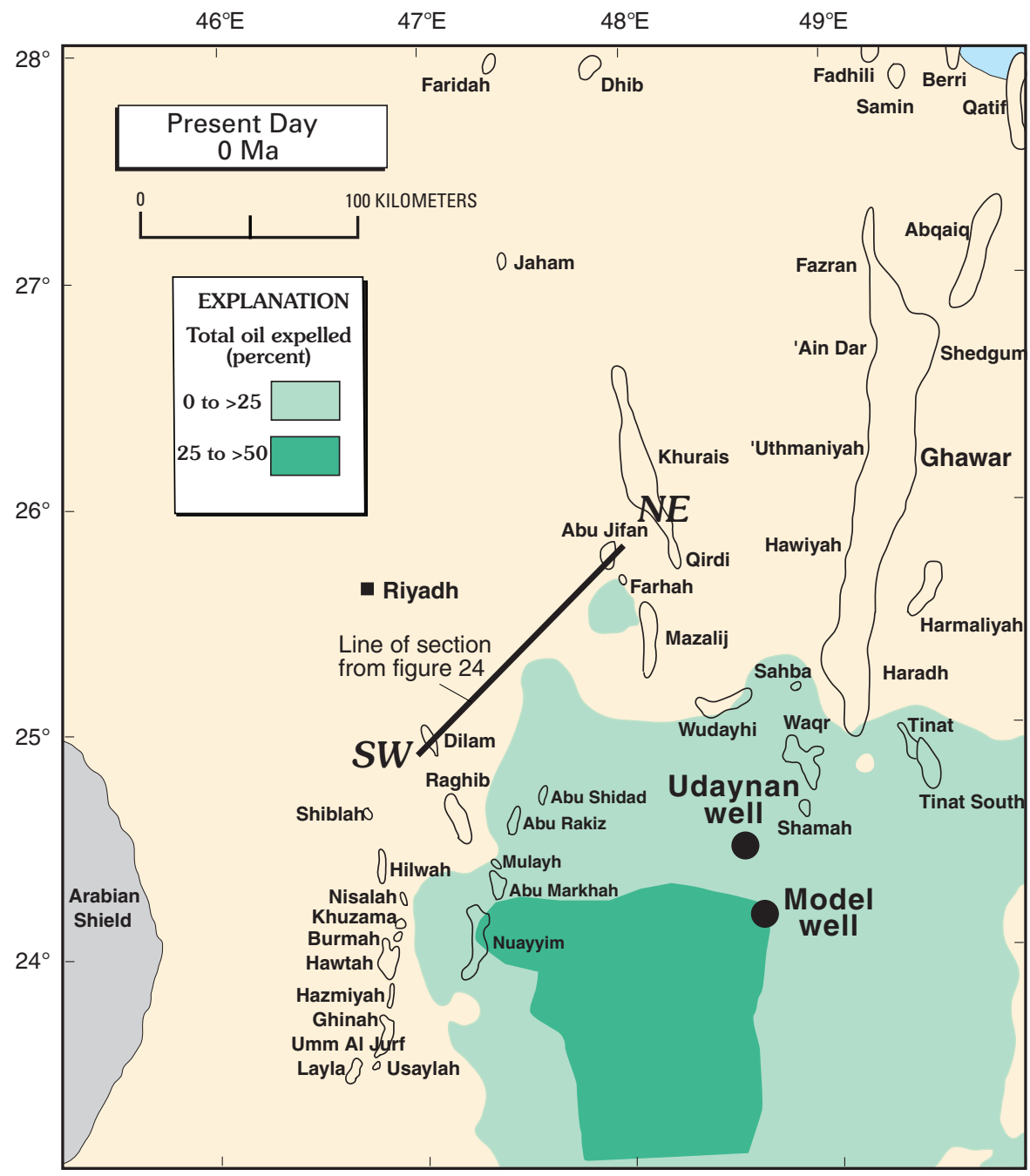

A

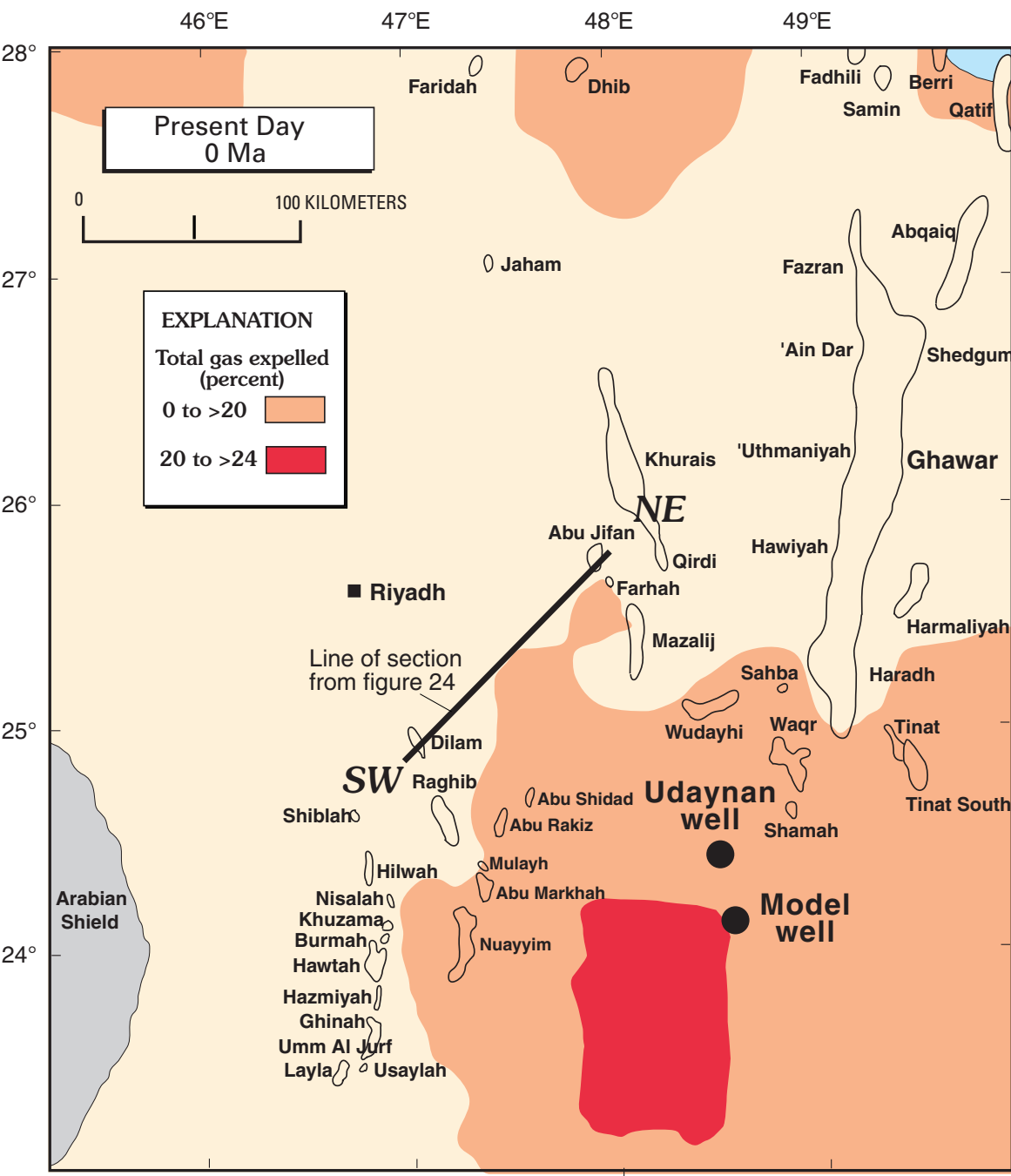

B

Figure 25. Central Arabia and Greater Ghawar area showing expulsion of oil and gas from Qusaiba hot shale source rock. A, Area of basin that has expelled oil from Qusaiba hot shale. Darker green indicates area that is most mature and has expelled the greatest amount ( 25 to 50 percent) of oil. $B$, Area of basin that has expelled gas from Qusaiba hot shale. Darker red indicates area that is most mature and has expelled the greatest amount ( 20 to $>24$ percent) of gas. Locations of Udaynan and hypothetical Model well of figure 23 and location of cross section of figure 24 are also shown. Modified from Abu-Ali and others (1999; 2001). 


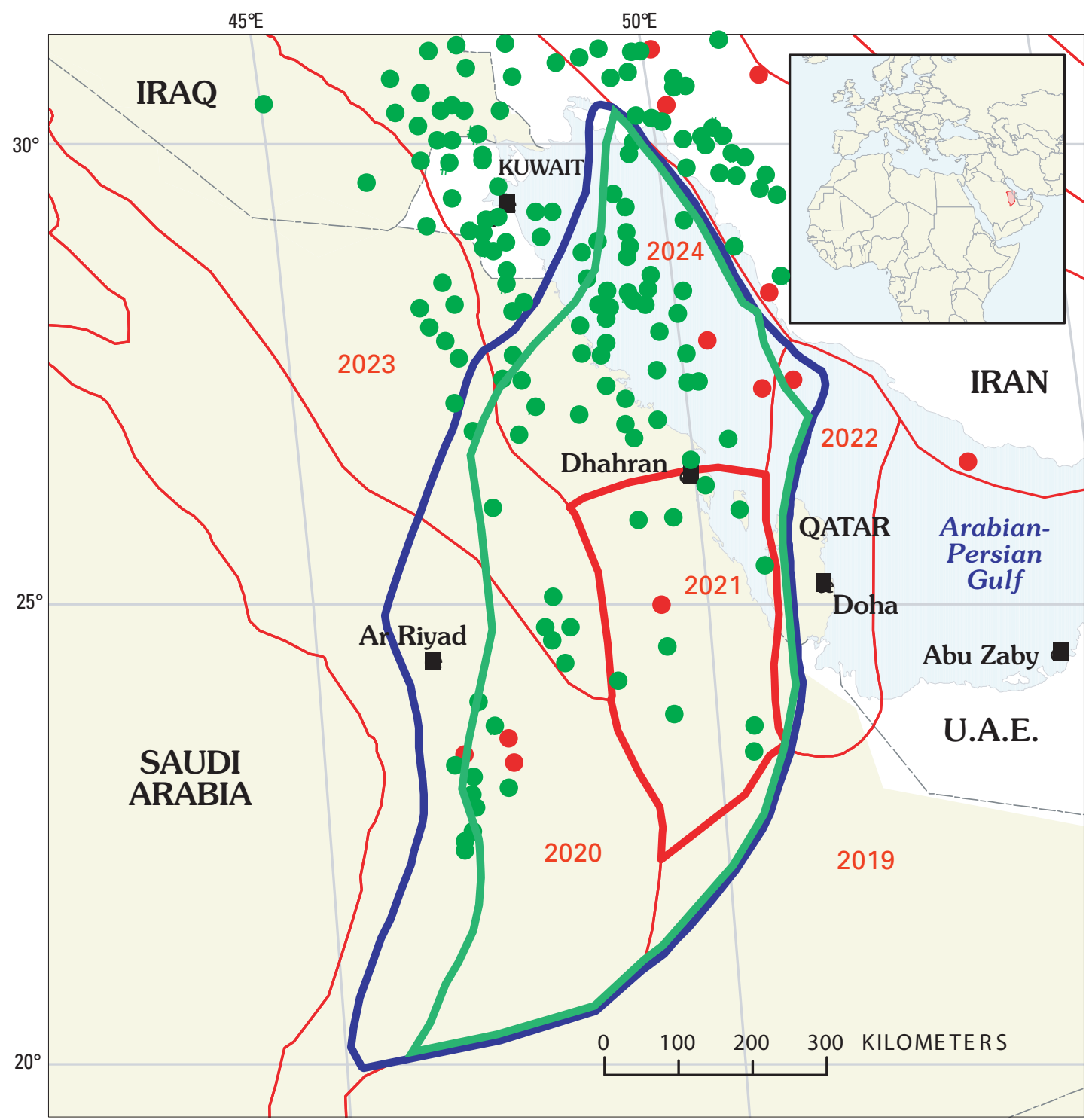

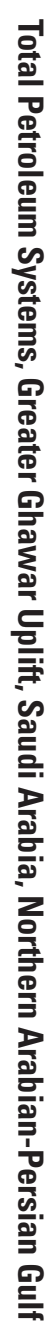

Figure 26. Central Arabia Qusaiba-Paleozoic Total Petroleum System, pod of active source rock, geologic provinces, and oil and gas field centerpoints in Greater Ghawar Uplift Province (2021) and surrounding provinces. U.A.E., United Arab Emirates. 


\section{Reservoirs}

Primary reservoirs of the Central Arabia Qusaiba-Paleozoic TPS are sandstones of the Permian Unayzah and Devonian Jauf Formations, and in the Gulf portion of the total petroleum system, basal transgressive marine sandstones and cyclic dolomitic shelf carbonates of the Late Permian Khuff Formation (figs. 1 and 13). Other reservoirs include clastics of the Pre-Qusaiba section that are fault bounded and sourced laterally by down-faulted Qusaiba Shale Member. These PreQusaiba clastic reservoirs include the Cambrian-Ordovician Saq Sandstone, shallow-marine sandstones of the Ordovician Qasim Formation (Senalp and Al-Duaiji, 2001), and Upper Ordovician glacial and periglacial clastics of the Zarqu and Sarah Formations (McGillivray and Husseini, 1992). Many of these Pre-Qusaiba clastics have had some hydrocarbon shows but are poor-quality reservoirs owing to silica cementation.

The Upper Permian Unayzah Formation is a complex succession of generally red continental clastics consisting of braided-plain, channel-fill, and eolian sand and flood-plain silt that were deposited on the pre-Unayzah (Hercynian) unconformity (Senalp and Al-Duaiji, 1995; Evans and others, 1997; Konert and others, 2001). Regional surface and subsurface data indicate that the Unayzah is widespread over much of the eastern Arabian Plate (Al-Laboun, 1987). A recent study by Heine (in press) showed that sandstones of the Unayzah in the southern Ghawar area are cold-climate (periglacial) dunes deposited on an eroded surface that trends across central Saudi Arabia, and possibly over Bahrain and Qatar (fig. 27). The Unayzah unconformably underlies the Upper Permian Khuff Formation. Deposition of continental clastics of the Unayzah represents a major change in sedimentation that preceded a major marine transgression and widespread deposition of carbonates and evaporites of the Khuff Formation.

The Unayzah Formation is composed of cycles of crossbedded, fine- to coarse-grained sandstones, siltstones, and claystones with thin beds of argillaceous limestone. In central Saudi Arabia, the lowermost part of the Unayzah consists of debris-flow gravels and coarse clastics, which infill the Hercynian erosional unconformity on the underlying Qusaiba Shale (Senalp and Al-Duaiji, 1995). The Unayzah Formation fines upward into more distal, braided-stream bars and channel-fill sandstones, and flood-plain siltstones. The cyclic nature of the Unayzah suggests a fluctuating sea level. The upper Unayzah unit $A$ is the principal reservoir averaging about 20 percent porosity. Permeability of several darcys is not uncommon; however, both porosity and permeability vary due to kaolinite and illite cements (McGillivray and Husseini, 1992).

In the Greater Ghawar area, the principal Pre-Khuff hydrocarbon reservoir in the southern area (Haradh substructure field at Ghawar, and adjacent Sahba, Waqr, and Tinat fields; figs. 10 and 19) is the Unayzah Formation, whereas the Lower to Middle Devonian Jauf Formation is the main producing reservoir in the northern Ghawar area (Ghawar substructure fields: Hawiyah, 'Uthmaniyah, and Shedgum; figs. 10 and 19). In the south Ghawar area, the Unayzah is generally divided into two sandstone reservoir units separated by a siltstone member (Wender and others, 1998). Gas is produced from most Paleozoic reservoirs at Ghawar; however, Qusaiba-sourced premium crude is produced from the Unayzah at the Tinat field structure immediately to the southeast. The Unayzah is missing in the north half of Ghawar field (McGillivray, 1994) but is present in the south half of Ghawar, where it thickens from 0 to greater than $152 \mathrm{~m}$ [500 ft] at Tinat field (fig. 28). Porosity of the upper Unayzah-A pay zone ranges from 5 to 25 percent and averages about 12 percent (Wender and others, 1998).

The shallow marine sandstones of the Devonian Jauf reservoir in the Ghawar area are well developed and commonly display high (30 percent) porosities at a depth of 4,260 m. In the northern Ghawar area, the Jauf reservoir ranges in thickness from 89 to $145 \mathrm{~m}$. The giant gas-condensate discovery at the Hawiyah substructure field at Ghawar is in Jauf sands. The Jauf sandstones are fine to medium grained, are weakly cemented by authigenic illite clay, and lack the silica cement that is prevalent and detrimental to reservoir quality of most other Pre-Khuff sandstones. The authigenic illite is thought to inhibit quartz cementation and to preserve porosity. At Ghawar field, and at Abu Sa'fah field in the offshore to the northeast of Ghawar (fig. 19), the Jauf reservoir is sealed by a distinctive shale-silt layer that is referred to informally as the D3B zone (fig. 13) (Wender and others, 1998).

The Late Permian-Early Triassic Khuff Formation unconformably overlies the Unayzah Formation. Gas was discovered in carbonate rock reservoirs of the Khuff in the Awali field domal structure of Bahrain in 1949. The Khuff Formation is ranked as the largest reservoir formation of non-associated gas in the world with recoverable reserves estimated at about 750 TCF (Konert and others, 2001). Khuff reserves include the largest gas field in the world at North dome (field), Qatar (figs. 3 and 19) discovered in 1971; its total reserves are estimated at 500 TCF (Alsharhan and Nairn, 1997, p. 574). The Khuff Formation produces primarily gas that probably formed by the cracking of oil (Bishop, 1995). Locally, the quality of Khuff gas depends upon the amounts of non-hydrocarbon gases, mainly $\mathrm{H}_{2} \mathrm{~S}, \mathrm{CO}_{2}$, and $\mathrm{N}_{2}$. The amount of $\mathrm{H}_{2} \mathrm{~S}$ increases with increasing temperature and depth, reflecting in-place conversion of hydrocarbon gases to $\mathrm{H}_{2} \mathrm{~S}$ by the thermochemical reduction of anhydrite sulfate (Konert and others, 2001).

In eastern Saudi Arabia, the Khuff Formation is divided into five units or members designated as Khuff A through E. However, throughout the Gulf region the Khuff may comprise as many as seven designated units or members (Al-Jallal, 1995). Most of the Khuff is composed of carbonates and evaporates; major siliciclastic facies increase towards the west. As many as four of the five units may be reservoirs and correspond to four depositional carbonate-anhydrite cycles where transgressive carbonate rocks are capped by regressive anhydrite facies (fig. 13). The Khuff Formation thickens from about $260 \mathrm{~m}$ in southwestern Saudi Arabia to more than $915 \mathrm{~m}$ in the central Rub 'al Khali Basin, 1,220 m in Oman, 


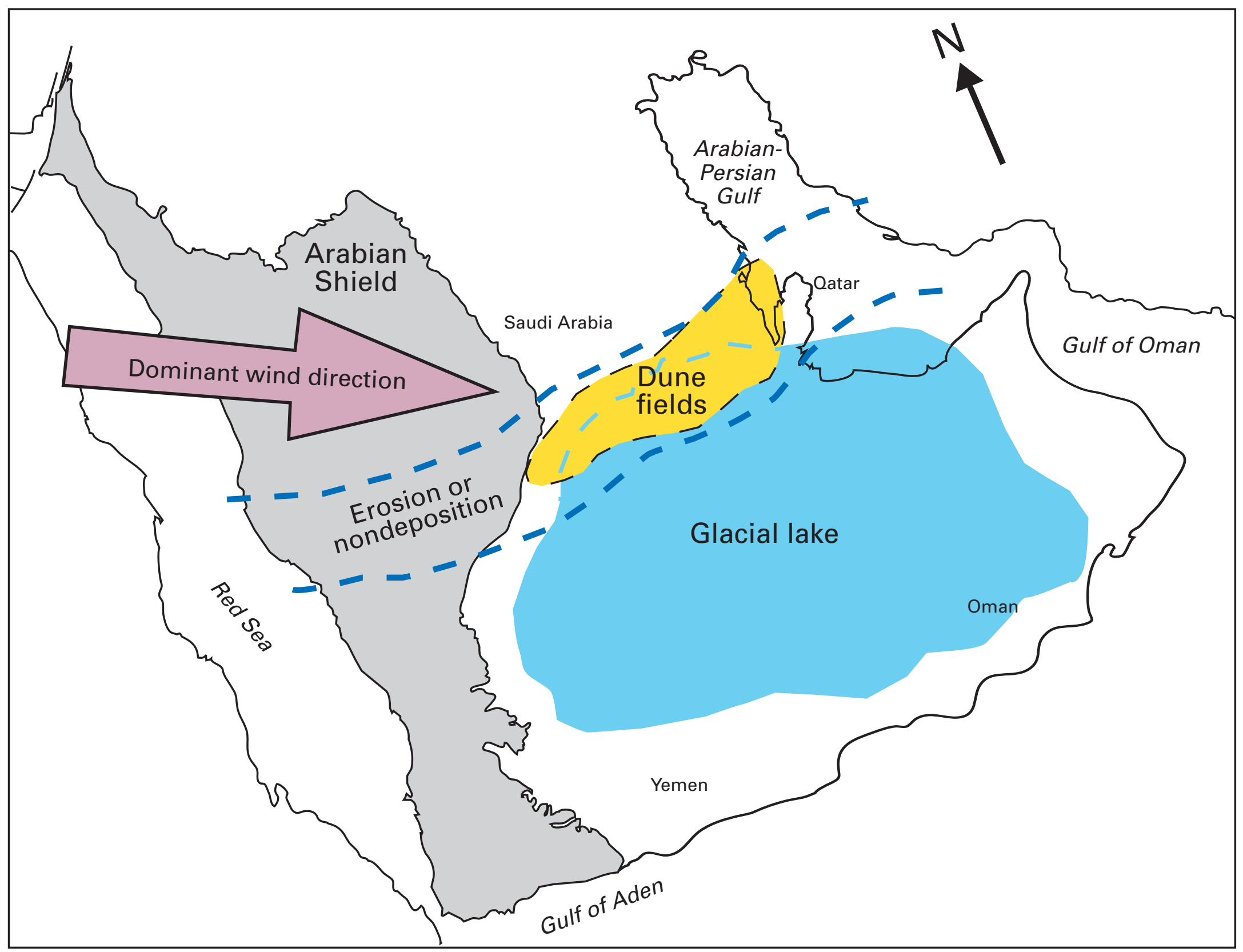

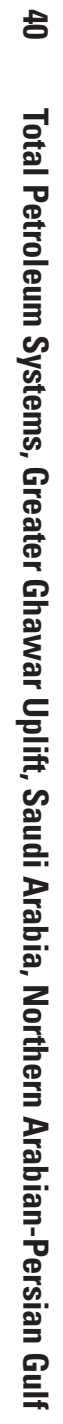

Figure 27. Arabian Peninsula during Early Permian showing area of erosion or nondeposition (blue dashed lines), known Unayzah dune fields (yellow area), probable glacial lake (blue area), and dominant wind direction (arrow) across central eroded portion of Arabian Peninsula. Modified from Heine (in press). 


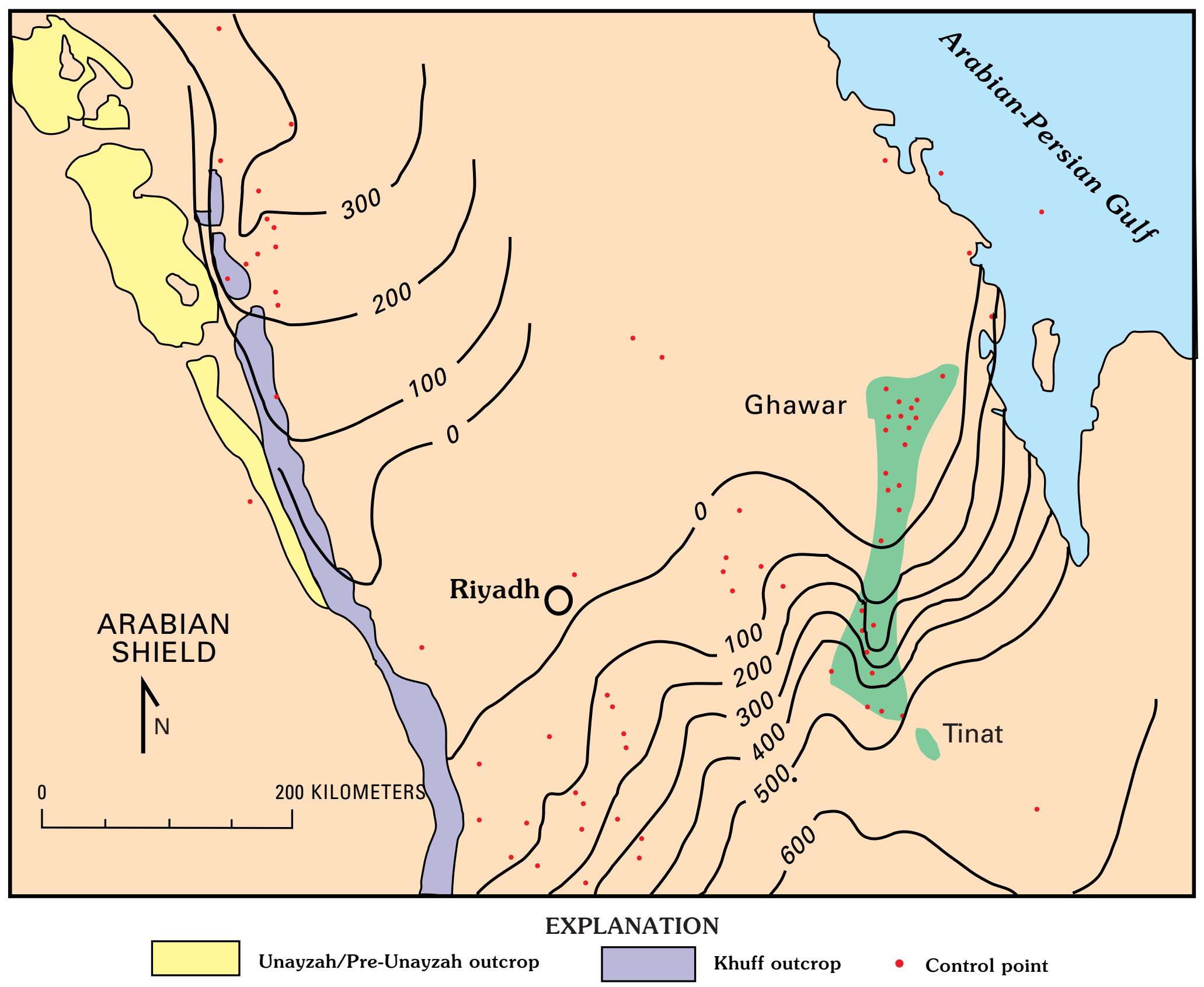

Figure 28. Isopach map of the Unayzah Formation in central Saudi Arabia, showing the Unayzah absent over the area of Riyadh and north half of Ghawar field and the Unayzah thickening to the north and south of this area. Contour interval $100 \mathrm{ft}$. Modifed from McGillivray (1994). 
and 1,520 $\mathrm{m}$ in Iran. Typical thickness for the Khuff ranges between $370 \mathrm{~m}$ and $490 \mathrm{~m}$ over most of central and eastern Arabia (Al-Jallal, 1995).

The basal Khuff section consists mostly of siliciclastics throughout southern Arabia. The "basal Khuff clastics" are shale, carbonaceous shale, limestone streaks, and incised channel-fill sandstones. Channel-fill sandstones of the basal Khuff clastics are as much as $18 \mathrm{~m}$ in thickness and generally cut deeply into the Unayzah Formation. In Hazmiyah field of central Saudi Arabia (fig. 19), the reservoir occurs entirely within these channel sandstones in the basal Khuff (Senalp and Al-Duaiji, 1995).

The Unayzah and basal Khuff sandstones form the principal reservoirs in central Saudi Arabia; however, widespread reservoir quality variations occur in these sandstone reservoirs owing to heterogeneous sedimentary facies and diagenetic history (Aktas and Cocker, 1995; Polkowski, 1997). Depositional facies strongly influenced porosity evolution in these sands: both porosity and permeability generally decrease with cementation and silt and clay content and increase with increasing grain size and cement dissolution.

Many of the Khuff carbonate units were deposited as a restricted evaporitic, carbonate shelf facies and include subtidal carbonate sand shoals, lagoons and bars that spread out as sheets across long distances, along with intertidal and supratidal sabkha facies. Evaporites were deposited over a great extent of the area; the present-day total anhydrite thickness is $107 \mathrm{~m}$ or more. In general, the best reservoirs are in highenergy carbonate buildups consisting of oolitic grainstones and intertidal dolomite mudstones formed during sea-level highstands at the shelf edge and along the shallow carbonate shelf (fig. 29); these were capped by impermeable anhydrite deposited during sea-level lowstands. Khuff carbonate reservoirs at Dammam and Abu Sa'fah fields are examples of such buildups. Wells producing from these reservoirs at Dammam and Abu Sa'fah commonly contain considerable amounts of non-hydrocarbon gases, particularly $\mathrm{H}_{2} \mathrm{~S}$. Quality of Khuff reservoirs is variable, and porosity of these reservoirs is highest where anhydrite percentage is lowest. Areas of high porosity in carbonate rocks of the Khuff in Iran, Qatar, and Bahrain define a broad belt of shallow shelf breaks that once bordered a restricted evaporitic carbonate shelf (fig. 29) (Al-Jallal, 1995). At Ghawar, anhydrite has reduced porosity of Khuff carbonates considerably; however, good reservoir porosity in the Khuff in central Arabia is attributed to the presence of the basal sandstone unit.

\section{Seal Rocks}

Many of the Ordovician sandstone reservoirs of the Sarah and upper Qasim Formations are sealed by the overlying Early Silurian Qusaiba Shale; however, lower sandstone members of the Qasim showing reservoir potential are sealed by the intraformational Ra' an Shale Member. The Lower Ordovician, informal Saq A sandstone unit of the Saq
Formation is sealed by the lower Hanadir Member of the Qasim Formation (fig. 13).

Reservoir sandstones of the Devonian Jauf Formation are capped by a very distinctive shaly unit informally referred to as the "D3B" stratigraphic marker or zone (fig. 13). The D3B Zone lies directly on the Jauf sandstones at Ghawar and is recognized by high resistivities on electric logs, and high velocities on sonic logs (Wender and others, 1998). The D3B Zone is better developed to the northeast of Ghawar where it forms the seal for Jauf gas-condensate accumulations in the northern Gulf at Abu Sa'fah field, about $70 \mathrm{~km}$ north of Bahrain (fig. 19). The D3B Zone was probably deposited during a rise in sea level and may represent a condensed section (Wender and others, 1998).

Impermeable units within the Permian lower Khuff Formation combine to form the primary seal for clastic reservoirs of the underlying Unayzah Formation. These impermeable anhydrites and carbonate rocks, and shale beds of the Khuff Formation also constitute the major regional seal for the Central Arabia Qusaiba-Paleozoic TPS; however, local intraformational seals within the Khuff are important for many of the Khuff reservoir units. Shales and tight carbonate rocks of the basal Khuff were deposited over a widespread area during the Late Permian sea-level rise. The basal Khuff forms the top seal to the Permian Unayzah reservoir in four-way structural closures in the southern Ghawar area (Wender and others, 1998). The basal Khuff also forms the top seal to the Devonian Jauf reservoirs in unconformity-related traps at Ghawar. Hercynian faults are also important as lateral seals in controlling hydrocarbon accumulations in the Ghawar area (Wender and others, 1998). The Khuff Formation also forms the seal for hydrocarbon accumulation in Unayzah reservoirs in updip, oil and gas fields of central Arabia (figs. 19 and 29) where the Qusaiba source rock is immature.

Anhydrite of the Khuff Formation evaporite facies was deposited over an extensive area of the Arabian shelf (fig. 29). Shelf-edge oolitic grainstone and intertidal dolomite reservoirs of the Khuff Formation are sealed by overlying cyclic, regressive anhydrite beds of the Khuff that were deposited during sea-level lowstands.

\section{Traps and Trap Styles}

Traps are mostly structural and related to basement block faulting, tectonic salt movement and deformation (halokinesis), and wrench faulting. Complex structural-stratigraphic traps also occur on flanks of Hercynian structures. Basement fault blocks are the result of preexisting zones of weakness established during accretion of the Arabian Plate in the Precambrian. High-angle reverse faulting occurred in central Saudi Arabia paralleling and overlying these zones of weakness (Husseini, 1991; Al-Husseini, 2000). Large, generally north trending, fault-bounded blocks developed from the Hercynian tectonic event (figs. 8 and 10). Structurally high blocks also coincide with major Bouguer gravity positives 


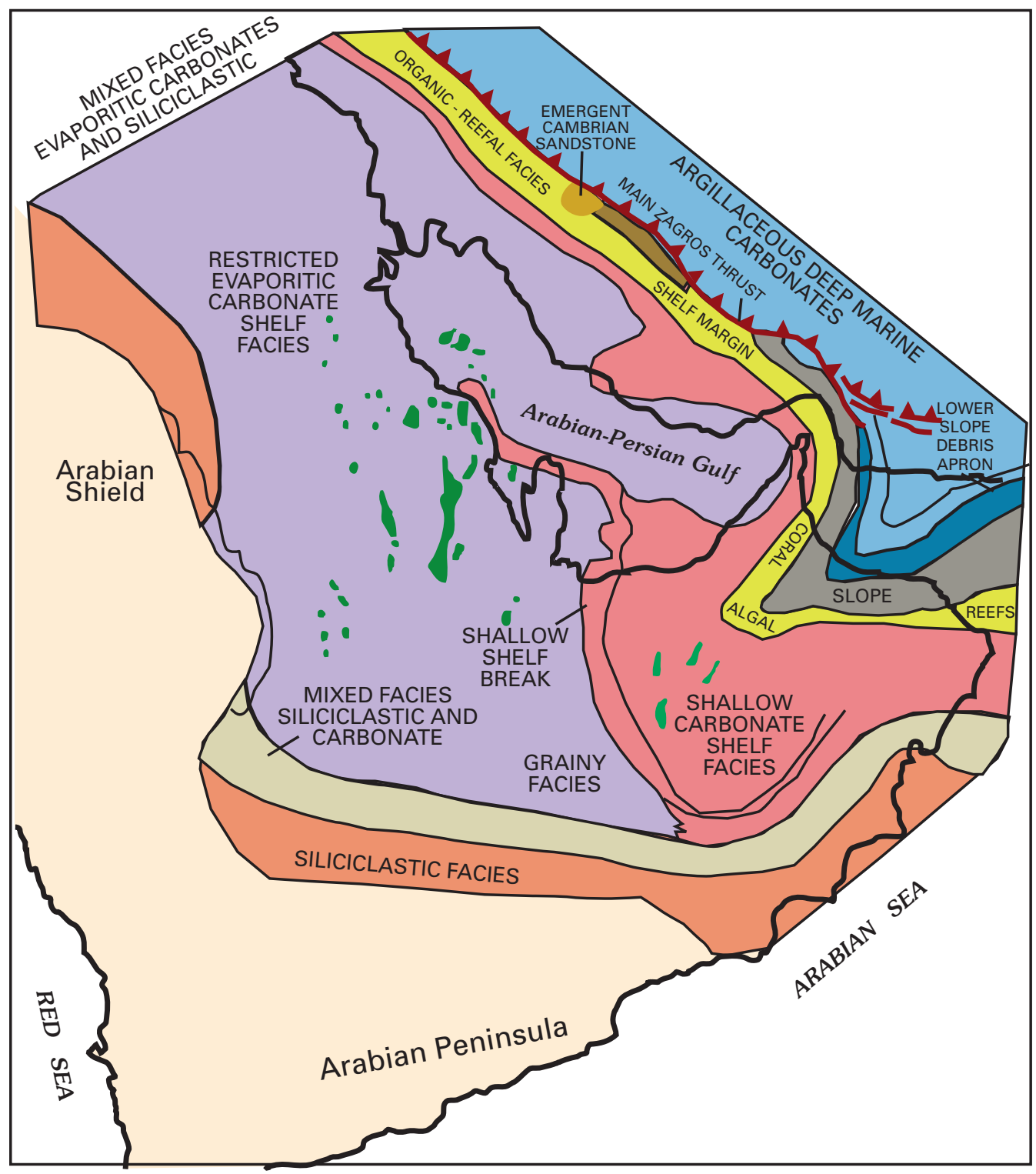

Figure 29. Major environments of deposition and regional facies of the Khuff Formation over the eastern Arabian Peninsula and Zagros Fold Belt. Modified from Al-Jallal (1995). 
and consist of either horst-block trends developed in relay patterns or east-tilted fault blocks with major bounding faults on the west flank (McGillivray and Husseini, 1992). Similarly, structures formed and modified from halokinesis of the underlying Hormuz Salt in the North Gulf Salt Basin (fig. 3) are also major trap-forming mechanisms of the Central Arabia Qusaiba-Paleozoic TPS.

Major trap formation and modification in the Central Arabian sub-basin, which includes both reactivated basement fault blocks and structures related to movements of Infracambrian salt, occurred in four main tectonic stages: (1) the Carboniferous Hercynian Orogeny; (2) Early Triassic Zagros rifting and opening of the Neo-Tethys Sea (fig. 8); 3) the First Alpine Orogeny during the Late Cretaceous (Coniacian-Campanian), associated with the collision event that led to the emplacement of the Semail Ophiolite Complex in Oman; and (4) the Second Alpine Orogeny during the middle to late Tertiary, associated with the opening of the Red Sea and collision of the Arabia and Eurasia plates (Wender and others, 1998). These main tectonic stages are shown in the trap formation column of the Central Arabia Qusaiba-Paleozoic TPS events chart of figure 21. Although many of the structures at Ghawar show major growth during the Carboniferous Hercynian event (figs. 10 and 12), other fields nearby that involve basement-related fault structures, including Abqaiq and Udaynan, indicate non-Hercynian growth and a much younger origin. These younger, "late" structures, which initiated major movement of Infracambrian salt that formed the domes of Dammam and Awali fields, were created during major uplift and erosion associated with the Late Cretaceous First Alpine Orogeny (Wender and others, 1998).

Several fields in central Saudi Arabia (fig. 19) that produce Silurian-sourced, super-light, sweet crude oil from both structural and stratigraphic traps in siliciclastics of the Permian Pre-Khuff Unayzah Formation are recent discoveries. Seismic profiles and structural map geometries of these fields suggest wrench faulting of the early to middle Paleozoic section with associated drape and drag of the overlying Paleozoic and Mesozoic section (Simms, 1995). Seismic sections in this area reveal that the basement and Paleozoic section are faulted with many reverse faults. The wrench fault system was initiated during the Hercynian Orogeny in the Middle Devonian and reactivated during periods of rifting and subduction along the Arabian Plate boundaries (Simms, 1995).

Stratigraphic traps also occur in some of the Paleozoic fields of central Saudia Arabia. Three types of stratigraphic traps have been identified along the Hawtah and Nuayyim structural trends in the Permian Unayzah sandstones of these Pre-Khuff fields (fig. 19). These stratigraphic traps are described as follows: (1) isolated reservoir sands that pinch out updip to the west, forming stratigraphic traps along the east flank of the Hawtah and Nuayyim trends; (2) truncation traps of upper Unayzah sandstones below the regional Pre-Khuff Unconformity; and (3) combination structuralstratigraphic traps where reservoir sand facies pinch out across structural highs (Evans and others, 1997).

\section{Arabian Sub-Basin Tuwaiq/Hanifa- Arab Total Petroleum System}

\section{General Description}

The Arabian Sub-Basin Tuwaiq/Hanifa-Arab TPS (202102) encompasses an area mostly within Saudi Arabia, western Qatar, and northern Gulf offshore of southern Iran along the Zagros Fold Belt (fig. 30). The Arabian Sub-Basin Tuwaiq/Hanifa-Arab TPS includes the entire Greater Ghawar Uplift Province and extends into the central part of the Interior Homocline-Central Arch Province (2020), the western flank of the Qatar Arch Province (2022), the north edge of the Rub 'al Khali Basin Province (2019), and the southeasternmost parts of both the Widyan Basin-Interior Platform (2023) and Mesopotamian Foredeep Basin (2024) Provinces (fig. 30). Petroleum system elements of the Arabian Sub-Basin Tuwaiq/ Hanifa-Arab TPS are included on the total petroleum system events chart of figure 31; source, reservoir, and seal rocks are generally outlined in the stratigraphic section showing the Greater Jurassic Petroleum System in figure 1. The Arabian Sub-Basin Tuwaiq/Hanifa-Arab TPS includes Ghawar field, as well as several other supergiant Jurassic oil fields of the central Arabian Peninsula such as Berri, Abqaiq, Abu Sa'fah, Khurais, Khursaniyah, and Dukhan (fig. 32).

The boundary of the Arabian Sub-Basin Tuwaiq/HanifaArab TPS (fig. 30) was determined primarily by the combined geographic extent of the Jurassic (Callovian-Oxfordian) source-rock facies of the Tuwaiq Mountain and Hanifa Formations and the shelf facies boundaries of the Jurassic Central Arabian intraplatform sub-basin (figs. 4 and 33) (Ayres and others, 1982; Chaube and Al-Samahiji, 1995; Cole, Carrigan, and others, 1994; Al-Husseini, 1997; Yousif and Nouman, 1997). To the north and west, the Arabian Sub-Basin Tuwaiq/ Hanifa-Arab TPS is bordered by Jurassic shelf facies (fig. 33) (Ayres and others, 1982; Al-Husseini, 1997), which separated the Jurassic Arabian intraplatform sub-basin from the Jurassic intraplatform Gotnia sub-basin that corresponds to the Gotnia/Barsarin/Sargelu/Najmah TPS (U.S. Geological Survey World Energy Assessment Team, 2000; Fox and Ahlbrandt, 2002). Similar to the Central Arabia Qusaiba-Paleozoic TPS, the Arabian Sub-Basin Tuwaiq/Hanifa-Arab TPS is also limited on the east by the structural axis of the Qatar Arch. The Arabian Sub-Basin Tuwaiq/Hanifa-Arab TPS laps onto the Central Arabian Arch to the south and southeast, and is further constrained by the western flank of the Rub 'al Khali Basin (fig. 3). Fields that produce from Jurassic reservoirs in the Arabian-Persian Gulf region are shown in figure 32.

\section{Petroleum Geochemistry}

\section{Source Rocks}

A major rise in sea level starting in the Callovian, combined with differential subsidence, led to drowning of the platform and the formation of the Central Arabian intraplatform sub-basin (Meyer and Price, 1993). The Central Arabian 


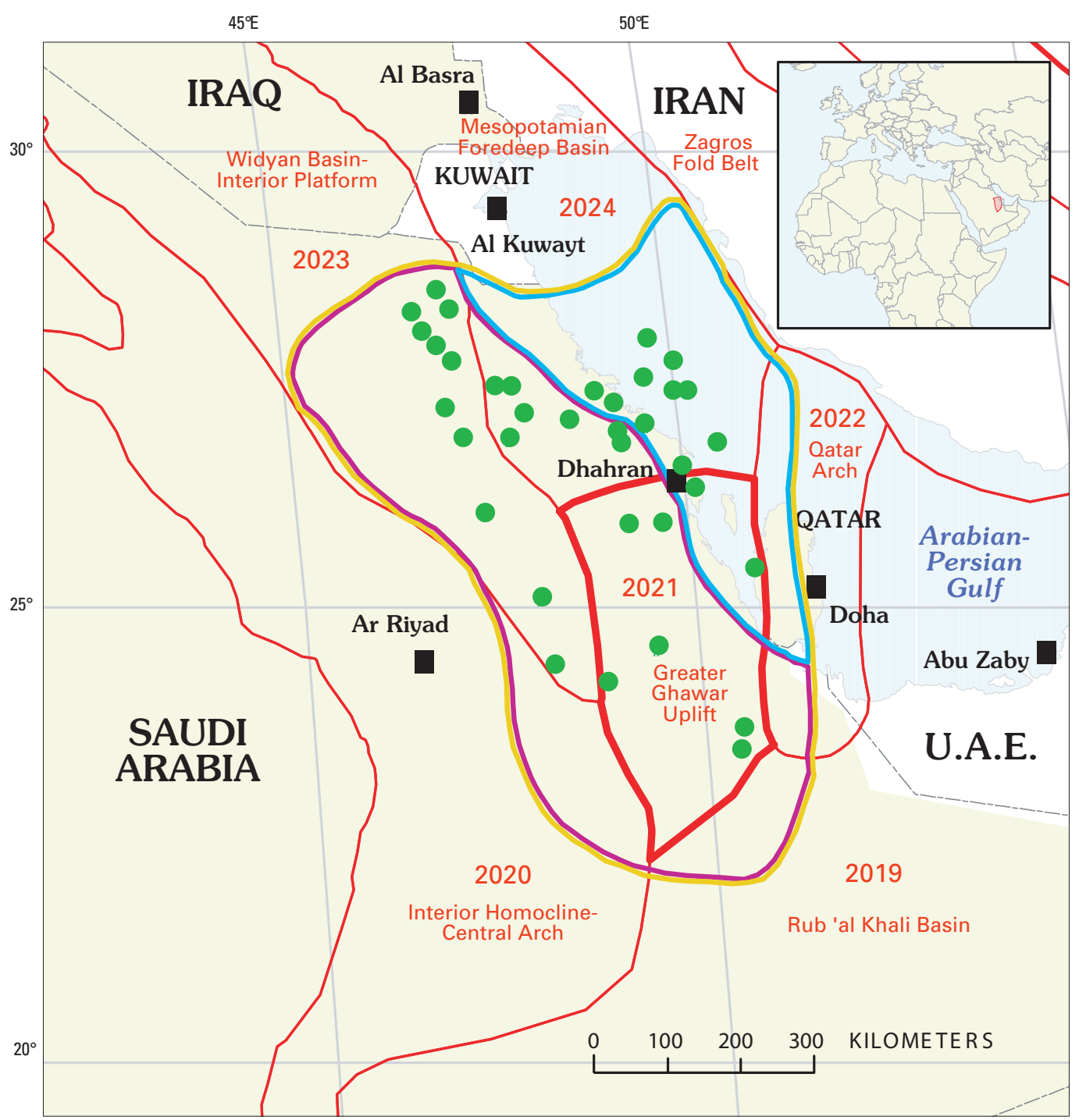

\section{EXPLANATION}

Greater Ghawar Uplift

Province (2021)

Arabian Sub-basin Tuwaiq/HanifaArab Total Petroleum System (202102)

Horst-Block Anticlinal Oil

Assessment Unit (20210201)

Salt-Involved Structural Oil

Assessment Unit (20210202)

2021 USGS geologic province boundary and number

Jurassic oil field centerpoint

Major city

Political boundary

Figure 30. USGS geologic province boundaries, Jurassic oil-field centerpoints, and geographic limits for Arabian Sub-Basin Tuwaiq/Hanifa-Arab Total Petroleum System (202102), Horst-Block Anticlinal Oil Assessment Unit, and Salt-Involved Structural Oil Assessment Unit. U.A.E., United Arab Emirates. 


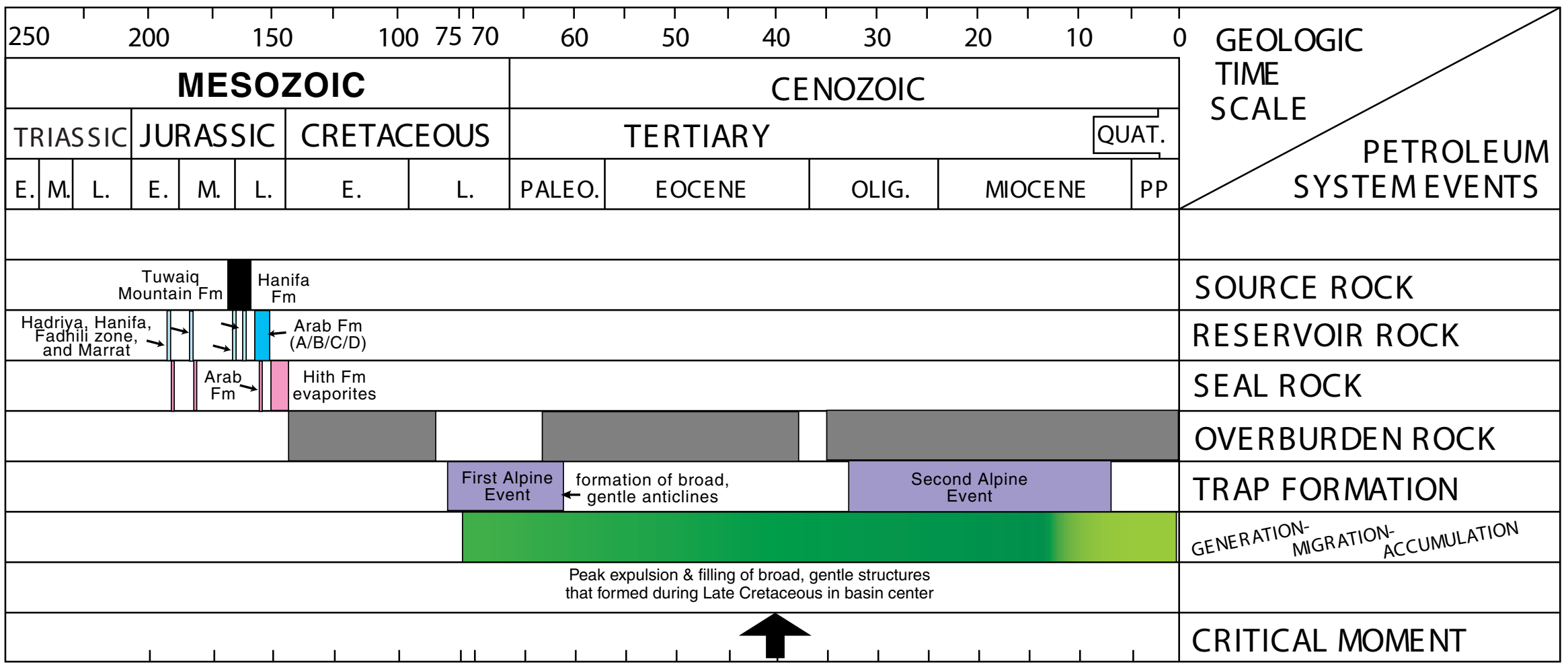

Figure 31. Events chart for Arabian Sub-Basin Tuwaiq/Hanifa-Arab Total Petroleum System (202102) of the Greater Ghawar Uplift Province and surrounding provinces of the Arabian Peninsula, showing total petroleum system elements and timing of trap formation and hydrocarbon generation. E., Early; M., Middle; L., Late; Paleo., Paleocene; Olig., Oligocene; PP, Pliocene-Pleistocene; Quat., Quaternary. 


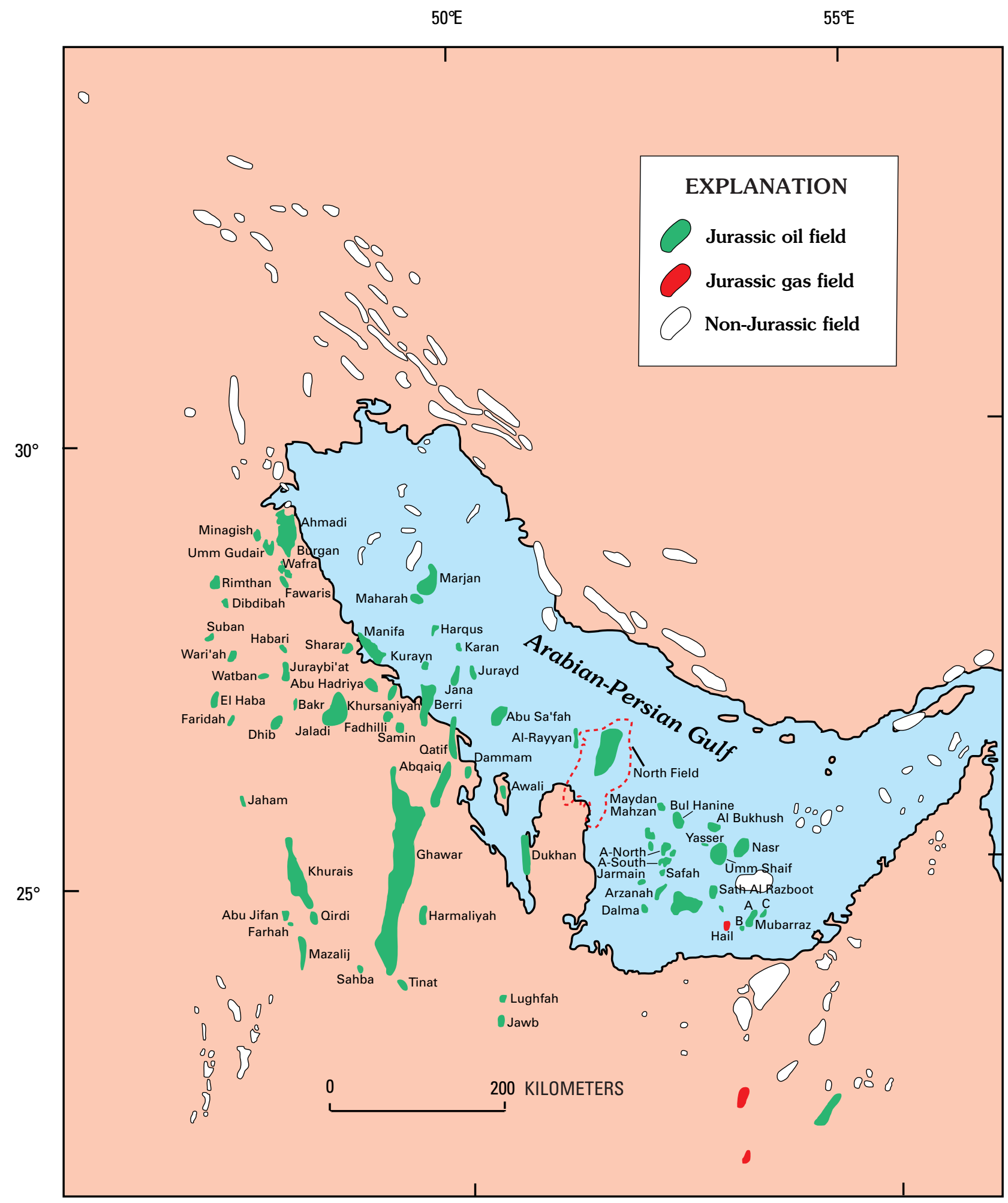

Figure 32. Oil and gas fields of the Arabian-Persian Gulf region with reservoirs in Jurassic age rocks. Modified from Al-Husseini (1997). 


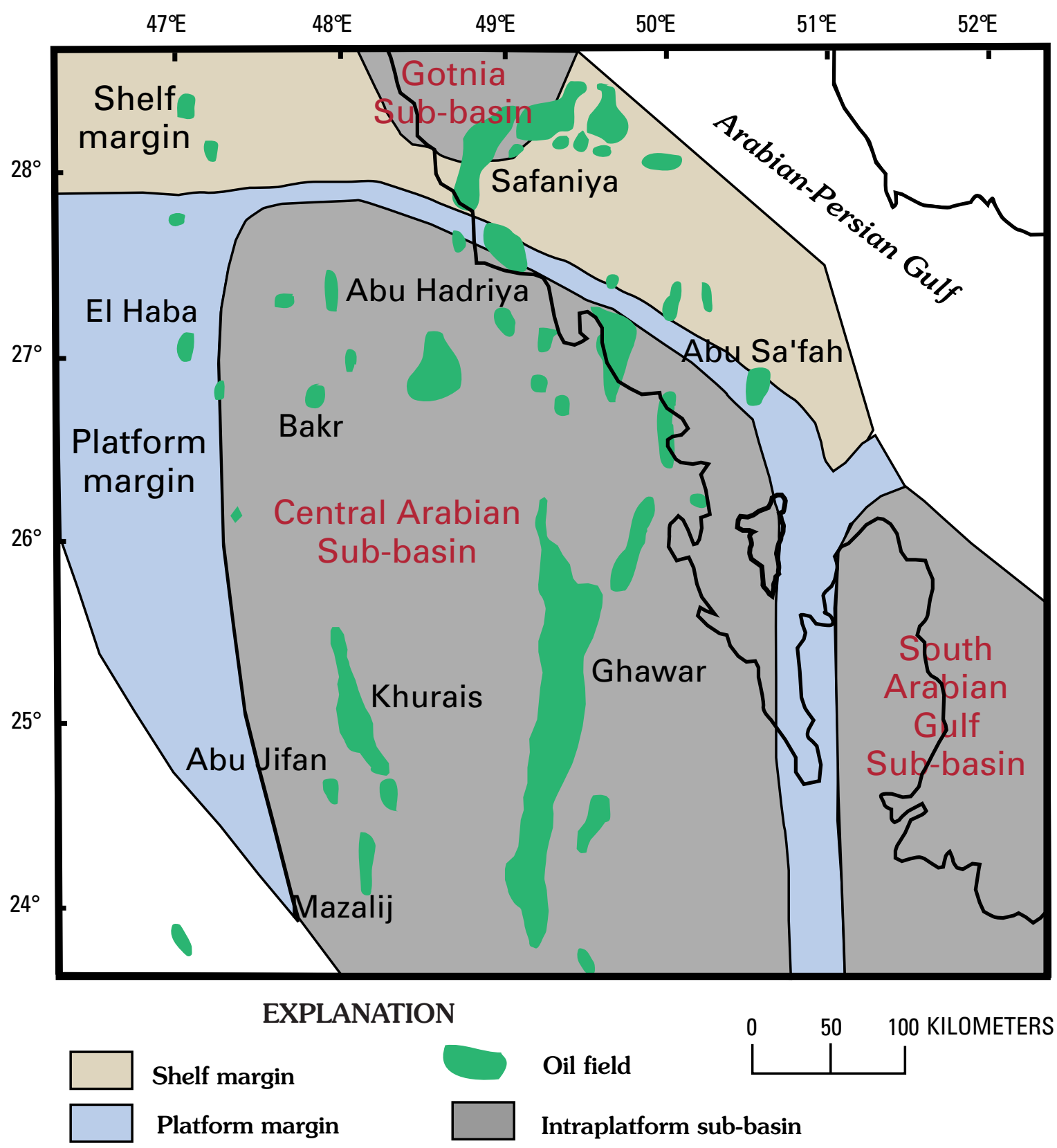

Figure 33. Paleogeography of Jurassic sub-basins of Arabian-Persian Gulf region, showing various facies during late Callovian to late Oxfordian centered around the Central Arabian sub-basin. Modified from Cole, Carrigan, and others (1994); Christenson and others (1977); Murris (1980); and Ayres and others (1982). 
sub-basin was separated from the deeper, more extensive intraplatform Gotnia sub-basin to the north, and from the shallower and shorter lived South Arabian Gulf intraplatform sub-basin to the south and east (fig. 33) by shallow grainstone shoals and dolomitized facies. Tropical and subtropical climate and restricted circulation created anoxic conditions and the production, accumulation, and preservation of organic-rich, mostly algal material over large parts of the intraplatform sub-basins (Cole, Carrigan, and others, 1994). Water depths were probably on the order of a few tens of meters; subsidence and depositional rates were minimally different because basinal intervals are only slightly thicker than surrounding shelf intervals. Deposition of the source facies in the Jurassic intraplatform sub-basins was initiated by a eustatic sea-level rise (Christenson and others, 1977; Ayres and others, 1982).

The areal extent of the source-rock facies and pod of active source rock for the Arabian Sub-Basin Tuwaiq/HanifaArab TPS of this report was mapped from the studies of Murris (1980), Ayres and others (1982), Frei (1984), Alsharhan and Magara (1994), Cole, Carrigan, and others (1994), Chaube and Samahiji (1995), Al-Husseini (1997), Alsharhan and Nairn (1997), Milner (1998), and Zeigler (2001) (figs. 34 and 35). Two organic-rich intervals of marine carbonates and marls of the Central Arabian Sub-Basin Tuwaiq/HanifaArab TPS generate a single superfamily of oils that constitute some of the world's largest single oil-field reserves. These excellent source-rock intervals are within the Jurassic Tuwaiq Mountain and Hanifa Formations. In the area of the Central Arabian sub-basin, the Tuwaiq Mountain Formation is the primary source rock; the Hanifa Formation is also an important petroleum source rock in this area, thus forming the "Tuwaiq/ Hanifa Superfamily" of oils for which the total petroleum system was designated.

The extent and thickness of this package of source rocks in which TOC exceeds 1 weight percent are shown in the isopach map of figure 34 (modified from Ayres and others (1982) and Cole, Carrigan, and others (1994)). Cole, Carrigan, and others (1994) showed that the Tuwaiq Mountain is the main source rock in central Arabia and in the area encompassing the Arabian Sub-Basin Tuwaiq/Hanifa-Arab TPS of this study. In contrast, the organic-rich facies of the Hanifa Formation and its equivalent, the Diyab Formation, are the major Jurassic source rocks that generate hydrocarbons produced from Jurassic reservoirs in the Rub 'al Khali Basin and Southern Arabian Gulf intraplatform sub-basin, respectively (Ayres and others, 1982).

The Tuwaiq Mountain is as much as $150 \mathrm{~m}$ thick (fig. 34) in the central part of the Central Arabian sub-basin (Ayres and others, 1982; Cole, Carrigan, and others, 1994) and laterally equivalent to the Upper Fadhili and Hadriya reservoirs deposited on the carbonate rock platform to the north. In a study of samples from wells at Khurais and Ghawar fields, Cole, Carrigan, and others (1994) reported that the Tuwaiq Mountain is extremely organic rich: TOC exceeds 13 weight percent and averages about 3.5 weight percent. In comparison, the Hanifa source rock of central Saudi Arabia is less than $30 \mathrm{~m}$ thick and averages about 2.6 weight percent TOC. Kerogen in both the Tuwaiq and Hanifa source rocks is primarily Type II (oil-prone) and is believed to consist primarily of blue-green algae (Ayres and others, 1982).

\section{Organic Geochemistry}

Oil-to-oil and oil-to-source rock correlations by Cole, Carrigan, and others (1994) showed that most of the oil in Jurassic reservoirs of eastern Saudi Arabia can be grouped into a single superfamily having specific characteristics. Generally, these oils consist of 30-40 percent saturate, 30-45 percent aromatics, and 20-30 percent resin plus sulfur and are classified as aromatic-intermediate oils. Sulfur content is high (1-4 percent or greater) and consistent with a marine carbonate source. Most oils from Upper Jurassic Arab and Hanifa reservoirs have API gravities ranging from $25^{\circ}$ to $35^{\circ}$ (Cole, Carrigan, and others, 1994). Lower sulfur content is normally associated with higher API gravities, as noted for Silurian sourced oils.

Jurassic oils have very similar light hydrocarbon characteristics on chromatographs and are quite different from deeper Permian reservoir condensates from Silurian sources, as previously discussed. Gas chromatograph/mass spectrometer analysis shows that most oils of central Arabia Jurassic reservoirs have similar biomarkers, particularly hopane and tricycline $(\mathrm{m} / \mathrm{z}$ 191) and steranes (m/z 217), which are indicative of oils derived from source rocks deposited in a carbonate environment under anoxic, reducing conditions (Cole, Carrigan, and others, 1994). Most carbon isotope $\left(\delta^{13} C\right)$ values are between -26.0 and $-26.5 \%$ for immature Tuwaiq Mountain and Hanifa source rocks and show excellent correlation to average $\delta^{13} \mathrm{C}$ compositions $(-26.6 \%$ ) for whole oils from reservoirs of the Jurassic Arab and Hanifa Formations. In contrast, the $\delta^{13} \mathrm{C}$ compositions of hydrocarbons in reservoirs of the Permian Khuff Formation range between -28.0 and $-30.5 \%$ (Abu-Ali and others, 1991; Cole, Abu-Ali, and others, 1994; Cole, Carrigan, and others, 1994) and are clearly a different family of oils than those from the Jurassic Arab and Hanifa reservoirs.

The oil-prone Tuwaiq Mountain source interval has excellent pyrolysis yields (S2 Rock-Eval yields) averaging $22.2 \mathrm{mg}$ hydrocarbons/g rock and hydrogen indices greater than $600 \mathrm{mg}$ hydrocarbon/g TOC. In contrast, the Hanifa of the Central Arabian sub-basin has hydrogen indices less than 400 , tending toward mixed oil and gas formation (Cole, Carrigan, and others, 1994). In summary, Jurassic source rocks and oils produced from Arab and Hanifa reservoirs are of similar bulk composition, and have similar carbon isotopic, gas chromatographic, and biomarker signatures. Additionally, Jurassic oils are different from the Silurian Qusaiba-sourced oil in Permian Unayzah and Khuff reservoirs.

\section{Maturation, Generation, and Expulsion}

Present-day levels of thermal maturity of the source rocks for the Arabian Sub-Basin Tuwaiq/Hanifa-Arab TPS are shown in the map of figure 35 . Timing of maturation and the generation of hydrocarbons in these source rocks are summarized in the total petroleum system events chart of figure 


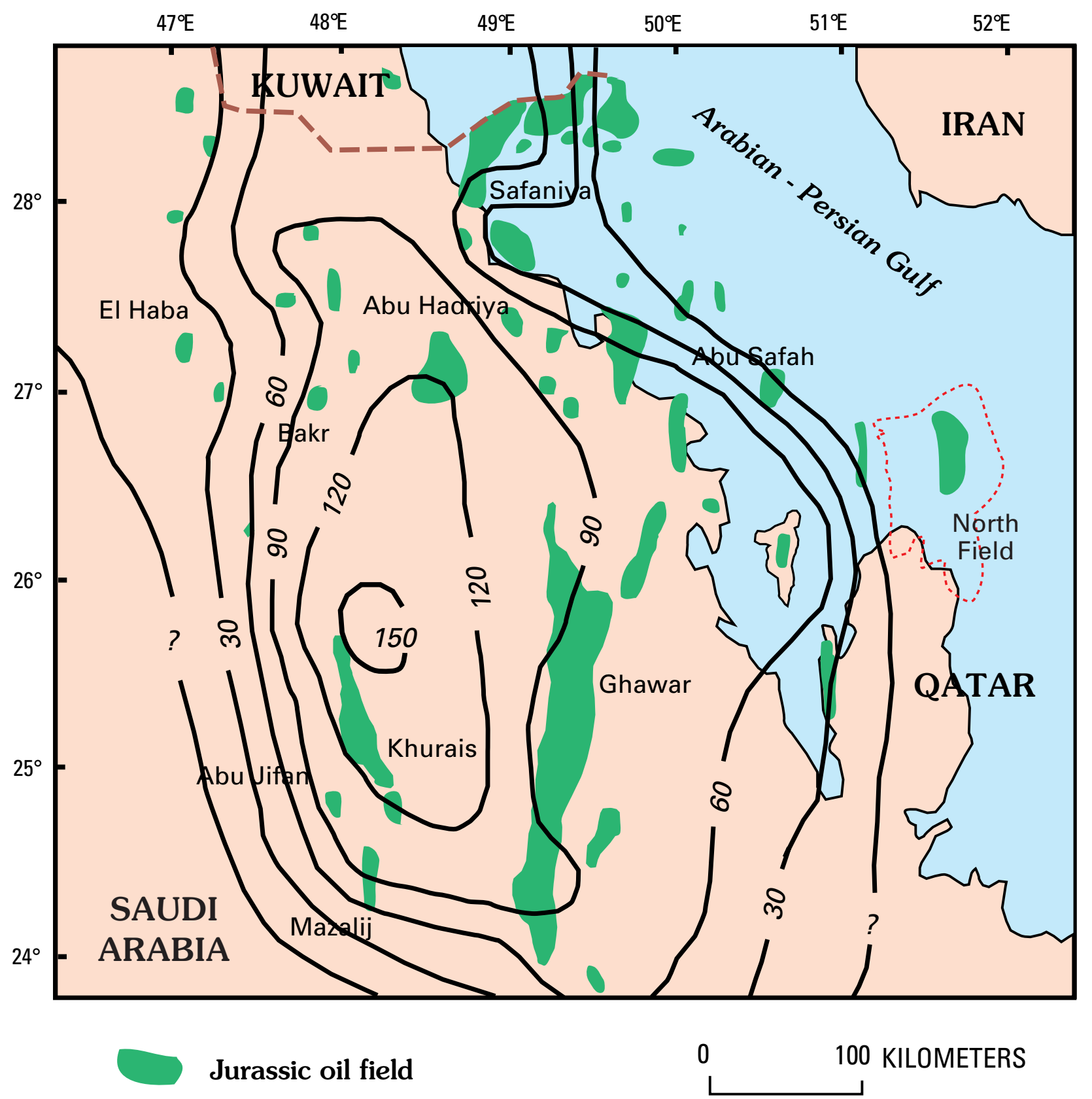

Figure 34. Isopach thickness of petroleum source-potential units of Upper Jurassic Tuwaiq Mountain Formation having $>1.0$ weight percent total organic content (TOC). Approximate limit of $>1.0$ weight percent organic matter shown by query. Modified from Cole, Carrigan, and others (1994); and Ayres and others (1982). Contour interval $30 \mathrm{~m}$.

Figure 35 (following page). Summary of present-day extent of thermal maturity levels as defined by vitrinite reflectance (Ro), and distribution of source facies for the Jurassic Hanifa Formation in central Saudi Arabia and Rub ‘al Khali Basin. Modified from Milner (1998). 


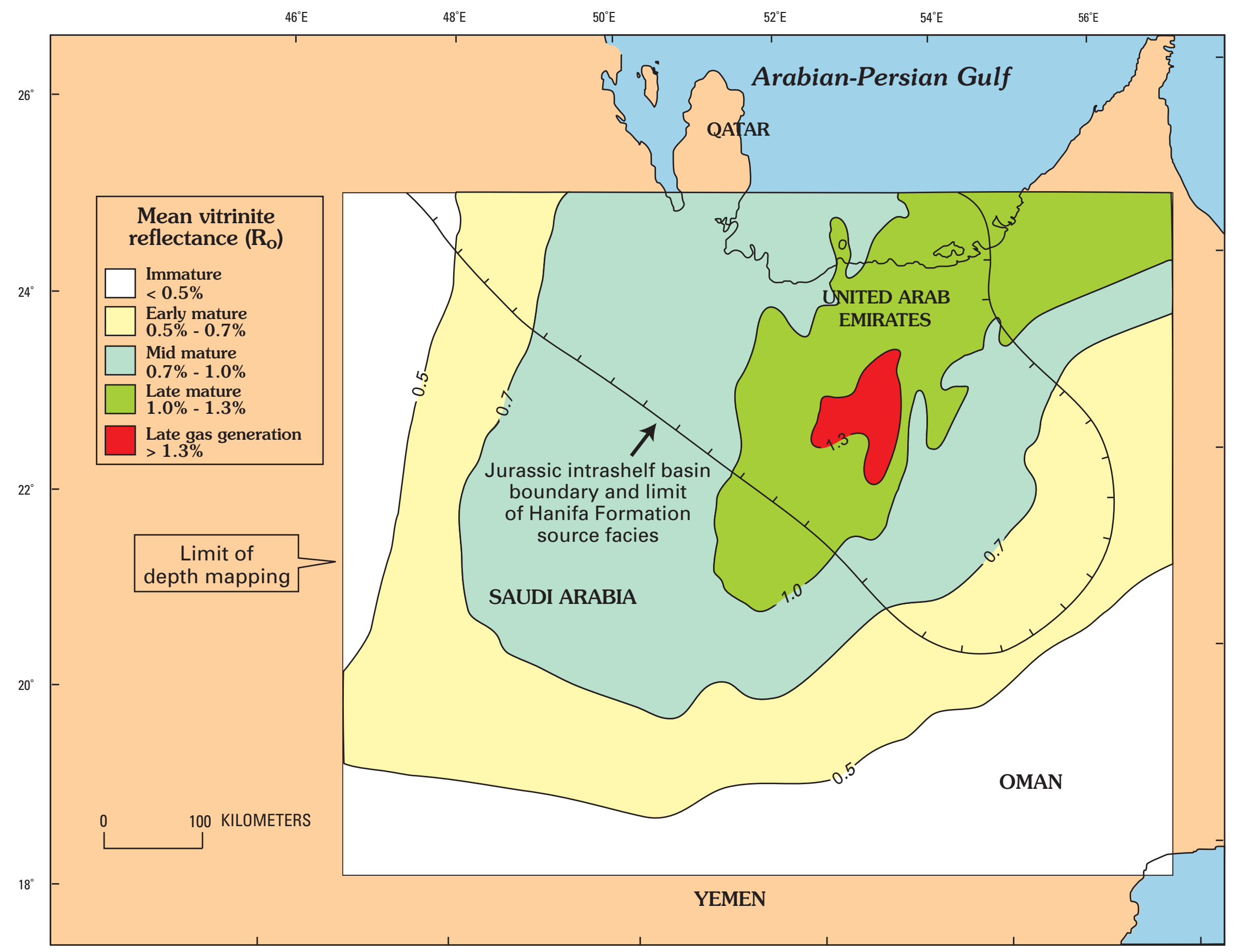


31 , in the maps of figure 36 , and in the burial history curve of figure 37. Modelling of source rock maturity and time of oil expulsion in figure 36 by Cole, Carrigan, and others (1994) has shown that the main phase of oil generation began in the Cretaceous about $75 \mathrm{Ma}$ (Campanian) for Tuwaiq Mountain/ Hanifa source rocks with greater than 1.0 weight percent TOC. In eastern Saudi Arabia and Kuwait this occurred in three principal areas, as follows: (1) southwest Kuwait in the Gotnia intraplatform sub-basin; (2) west-central northern Gulf near Safaniya and Abu Hadriya fields; (3) southwestern northern Gulf south of Bahrain at Dammam field, Qatar, and to the east and southeast of Ghawar field. According to the model of Cole, Carrigan, and others (1994), oil expulsion began to cease in portions of the northern Gulf (areas 2 and 3) about $25 \mathrm{Ma}$ (Oligocene) and in southwestern Kuwait by present day. Also, main-phase oil expulsion in Jurassic source rocks is occurring today in many parts of the Central Arabian intraplatform sub-basin. In contrast, Jurassic source rocks are immature to early mature in the northern Gulf, north of Qatar along the Qatar Arch, and in the area of Khurais, Abu Jifan, and Mazalij fields (fig. 36). Similarly, burial-history modeling in a structurally deep part of the basin west of Safaniya field (fig. 37) shows that Jurassic Tuwaiq/Hanifa source rocks first entered the main level of thermal maturity for oil generation during the Cretaceous, about $75 \mathrm{Ma}$. The burial curve of figure 37 also shows that the Tuwaiq/Hanifa source rocks near Safaniya field are presently in the late stage of oil generation, consistent with the "end of oil expulsion to oil preservation" stage of figure 36. According to the model of Cole, Carrigan, and others (1994), initial generation (early maturity) in these Jurassic source rocks occurs at a mean vitrinite reflectance $\left(\mathrm{R}_{\mathrm{o}}\right.$ ) of about 0.45 percent (fig. 37); thus, rocks having an $\mathrm{R}_{\mathrm{o}}$ of less than 0.45 percent are immature. Generation of oil at ${ }^{o}$ relatively low maturity ( $R_{0}$ equal to 0.45 percent) is due to the predominantly high sulfur, type II-S kerogen comprising the source rocks. Type II-S kerogen characteristically generates hydrocarbons at comparatively low thermal maturity (Baskin and Peters, 1992; Lewan, 1998).

At Awali field, Bahrain, Chaube and Al-Samahiji (1995) showed that the Hanifa source facies is as much as $46 \mathrm{~m}$ thick. They concluded that the onset of oil generation in the Hanifa at Awali began in the Eocene (about 45 to $50 \mathrm{Ma}$ ) and charged Jurassic reservoirs; however, to the north and east of Awali, oil generation was later, or source rocks are immature at present day. This interpretation is comparable to the data of Cole, Carrigan, and others (1994). Additionally, in a study of the Rub 'al Khali Basin, Milner (1998) also reported $\mathrm{R}_{\mathrm{o}}$ data showing comparabIe maturities of the Jurassic Hanifa source rock in the southern part of the Greater Ghawar Uplift Province (fig. 35) to those reported by Cole, Carrigan, and others (1994) and Chaube and Al-Samahiji (1995).

\section{Reservoirs}

Reservoirs of the Arabian Sub-Basin Tuwaiq/HanifaArab TPS and their relation to source and seal rocks are summarized in both the stratigraphic section of figure 1 (as part of the Greater Jurassic Petroleum System) and the total petroleum system events chart of figure 31. Late Jurassic (Tithonian) eustatic variations of the Arabian platform resulted in the deposition of carbonate rock-anhydrite cycles (figs. 1 and 14) that constitute the dominant reservoirs and caprocks (Arab Formation carbonate rocks and Arab Formation and Hith Formation evaporite seal rocks) of the Arabian Sub-Basin Tuwaiq/Hanifa-Arab TPS. Late Tithonian evaporitic conditions on a vast platform (fig. 38) produced the Hith Anhydrite and formed inland salt lakes in the western structural Rub 'al Khali Basin and intraplatform Gotnia sub-basin (Al-Husseini, 1997). Any significant loss of hydrocarbons generated within this Jurassic system was prevented by the regionally extensive, overlying evaporite seals; thus, only limited vertical migration occurred. The present-day sabkha depositional setting that extends along most of the southern and southwestern coasts of the Gulf is an analog for the setting of the Arab and Hith Formations (Alsharhan and Whittle, 1995).

The primary reservoirs are commonly 10 - to 30 -m thick, cyclic shallow-water, platform carbonate grainstones of the Upper Jurassic Arab Formation (Arab A, B, C, and D). Arab $\mathrm{D}$ is the primary reservoir with an average porosity of about 25 percent. Moreover, the Arab D reservoir accounts for most of the Jurassic oil production in the Arabian-Persian Gulf region, forming many supergiant and giant fields. A few reasons why the Arab D reservoir is a prolific producer of hydrocarbons are that it is in close stratigraphic position above the Tuwaiq Mountain and Hanifa source rocks and is sealed regionally by the Arab-D anhydrite (fig. 14). Also, the Arab D is the main reservoir at supergiant Ghawar field. The Arab D consists of several (at least four) major upward-shoaling cycles that were initiated in deeper water and shoaled to near sea level. Porosity and permeability in the reservoir are dependent on lithology, especially the type of dolomite present in the cycles, and microporosity, all of which play a major role in productivity (Bouroullec and others, 1995; Douglas, 1996; Cantrell and Hagerty, 1999; Saner and Sahin, 1999; Cantrell and others, 2001). For example, the Arab D reservoir at the 'Uthmaniyah substructure (fig. 10) field of Ghawar is a 91-m thick carbonate rock sequence consisting of various carbonate rock types that exhibit an overall stratigraphic downward decrease in porosity with a corresponding increase in dolomite content. The granular facies is the most porous and permeable lithofacies in the Arab D (Saner and Sahin, 1999).

The Arab D reservoir at Harmaliyah field, Saudi Arabia (fig. 32), is characterized by high primary porosity that was preserved because of early or pre-burial diagenesis. Porosity preservation was not caused by early emplacement of hydrocarbons into an uncompacted reservoir (Purser, 1978; Ibrahim and others, 1981). At Ghawar field, Saudi Arabia, Cantrell and others (2001) have identified at least five distinct types of dolomite in the Arab D reservoir. One dolomite type, referred to as the "super-k" type, is medium- to coarse-crystalline dolomite with good reservoir quality and appears to be responsible for high fluid flow in the Arab D, "Zone 2" reservoir. 


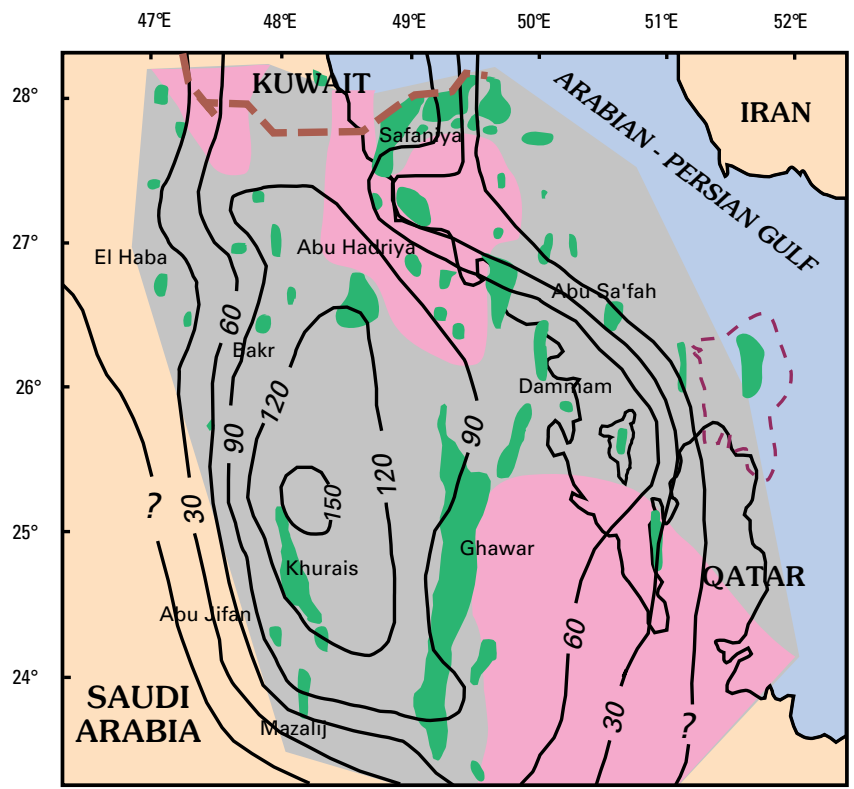

$75 \mathrm{Ma}$

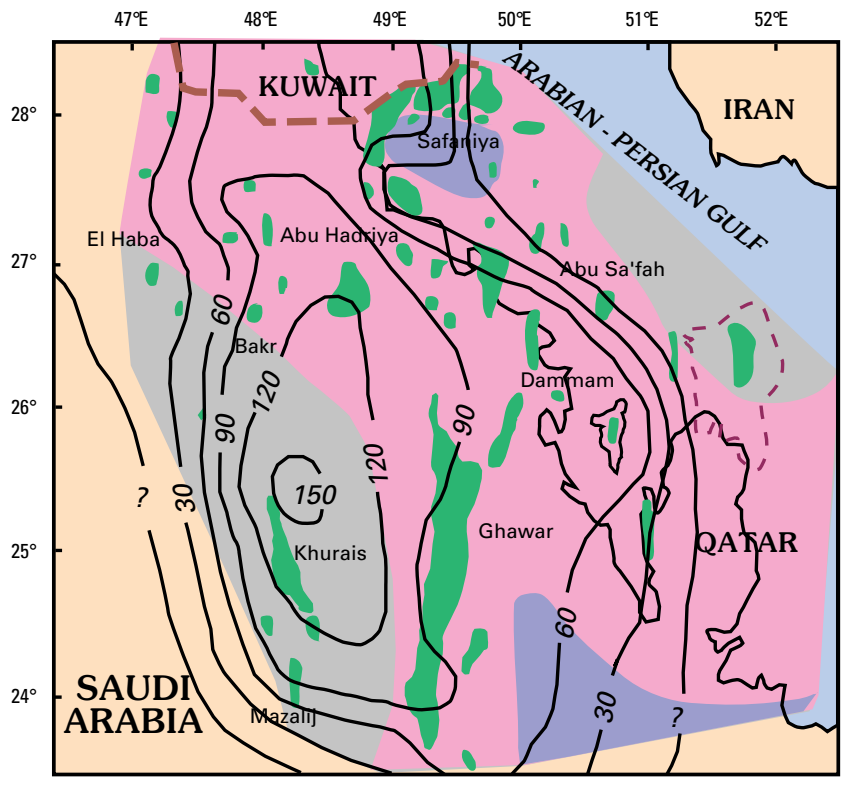

$25 \mathrm{Ma}$

Jurassic oil field

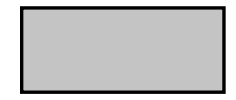

Immature to early mature generation

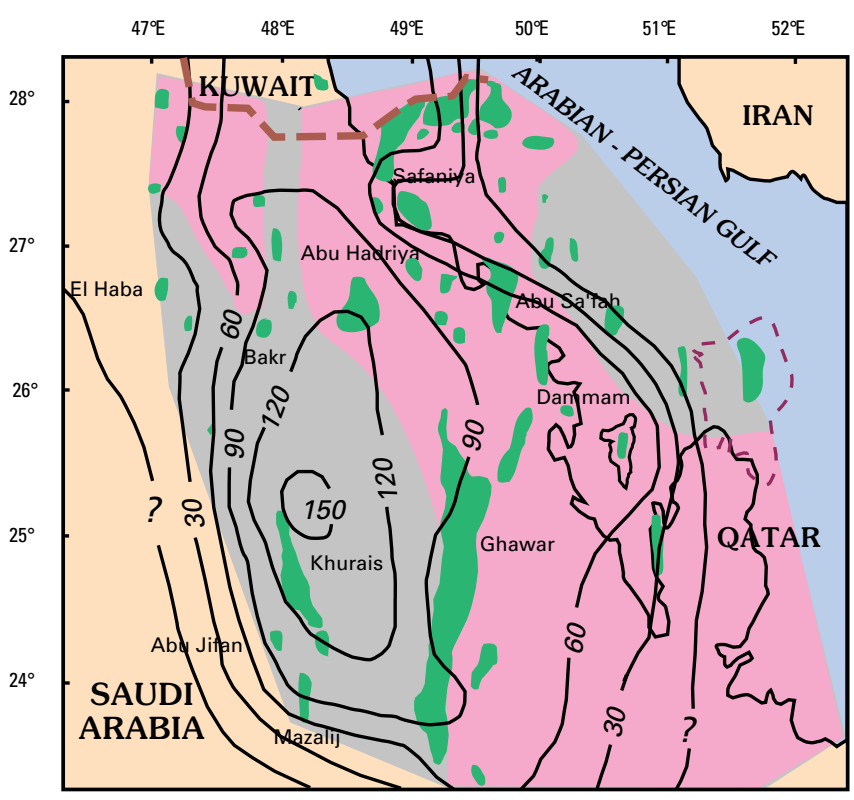

$50 \mathrm{Ma}$

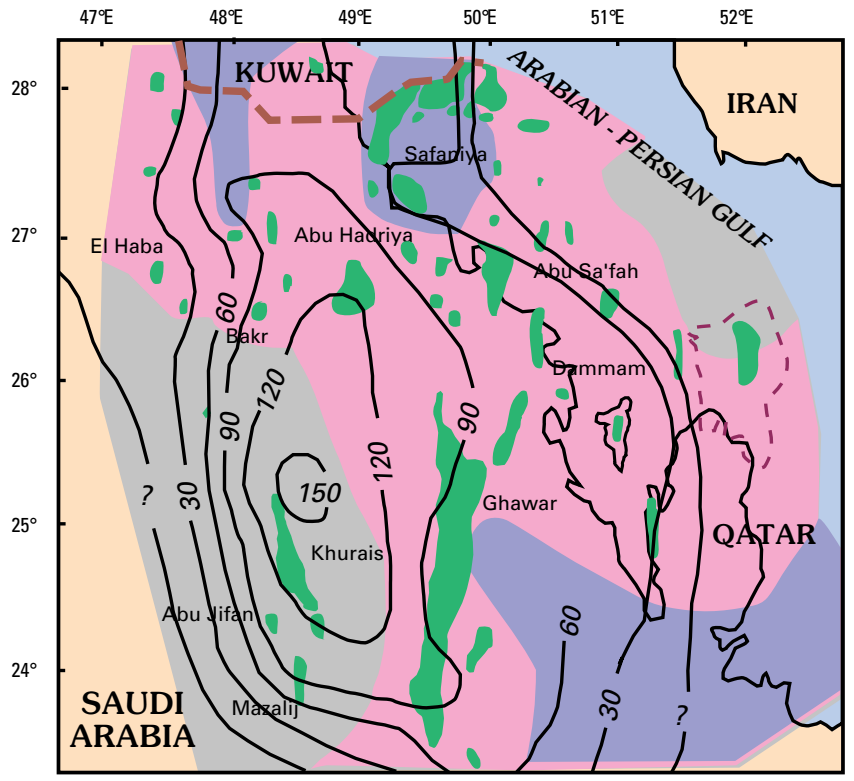

Present Day

EXPLANATION

$\therefore$ North field (Paleozoic gas)

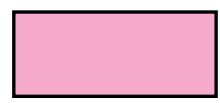

Main phase oil expulsion
$0 \quad 50 \quad 100$ KILOMETERS

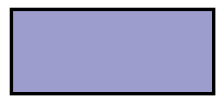

End of oil expulsion to oil preservation

Figure 36. Maps of central Saudi Arabia and northern Arabian-Persian Gulf area, showing hydrocarbon maturity, generation, and expulsion of oil from Jurassic source rocks at $75 \mathrm{Ma}, 50 \mathrm{Ma}, 25 \mathrm{Ma}$, and present day. Also shown are oil field outlines and isopach thickness of Hanifa Formation with $>1.0$ percent total organic carbon. Approximate limit of $>1.0$ weight percent TOC source rock shown by query. Modified from Cole, Carrigan, and others (1994) and Ayres and others (1982). Contour interval $30 \mathrm{~m}$. 


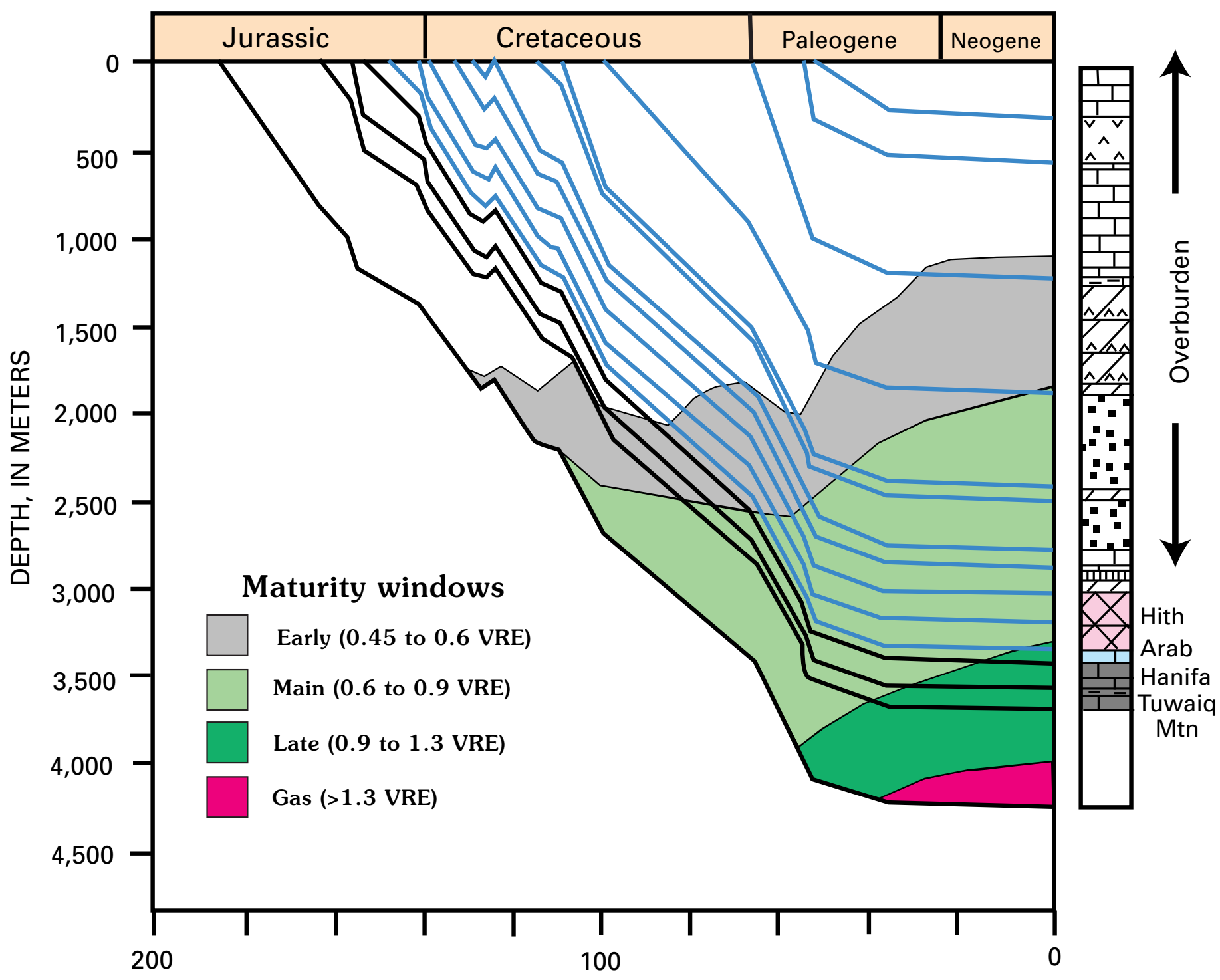

TIME, IN MILLIONS OF YEARS

Figure 37. Burial history and petroleum generation model for Tuwaiq/Hanifa source rocks near Safaniya field. Modified from Cole, Carrigan, and others (1994). VRE, vitrinite reflectance equivalent.

The Arab Formation is about $150-210 \mathrm{~m}$ thick in the area of Qatar and Bahrain; the type section for the Arab Formation is the Dammam number 7 well (located in Dammam field (fig. 32) in eastern Saudi Arabia), rather than an outcrop description (Alsharhan and Whittle, 1995). In the onshore Qatar area, the Upper Jurassic (Arab and Hith Formations) is subdivided into the Fahahil, Qatar, and Hith Formations. In offshore Qatar, the Qatar and Fahahil Formations are grouped informally as the "Arab zone" and are equivalent to the Arab Formation defined in Saudi Arabia. The four carbonate rock portions of the cycles from top to bottom, however, are referred to as I, II, III, and IV and are equivalent to Arab reservoir members A through D. The interval consisting of limestone I through III (Arab A-C) is formally referred to as the Qatar Formation; the lowermost limestone IV (Arab D) is designated as the Fahahil Formation, as defined by the Qatar Petroleum Company from a well in Dukhan field (Alsharhan and Whittle, 1995).

Secondary reservoirs of the Arabian Sub-Basin Tuwaiq/ Hanifa-Arab TPS include the porous carbonate-rock units within the Hanifa and Tuwaiq Mountain Formations. These porous carbonate-rock units are referred to as the Hanifa reservoir facies and the Hadriya reservoir facies, respectively, and comprise large-scale upward-coarsening, shallowing-upward, carbonate-rock platform sequences (McGuire and others, 1993). The Hanifa reservoir facies consists of porous (5-30 percent, mostly microporosity), fine-grained, mud-supported limestones and subordinate dolomites with low matrix permeabilities. High-angle fractures are important for production in 


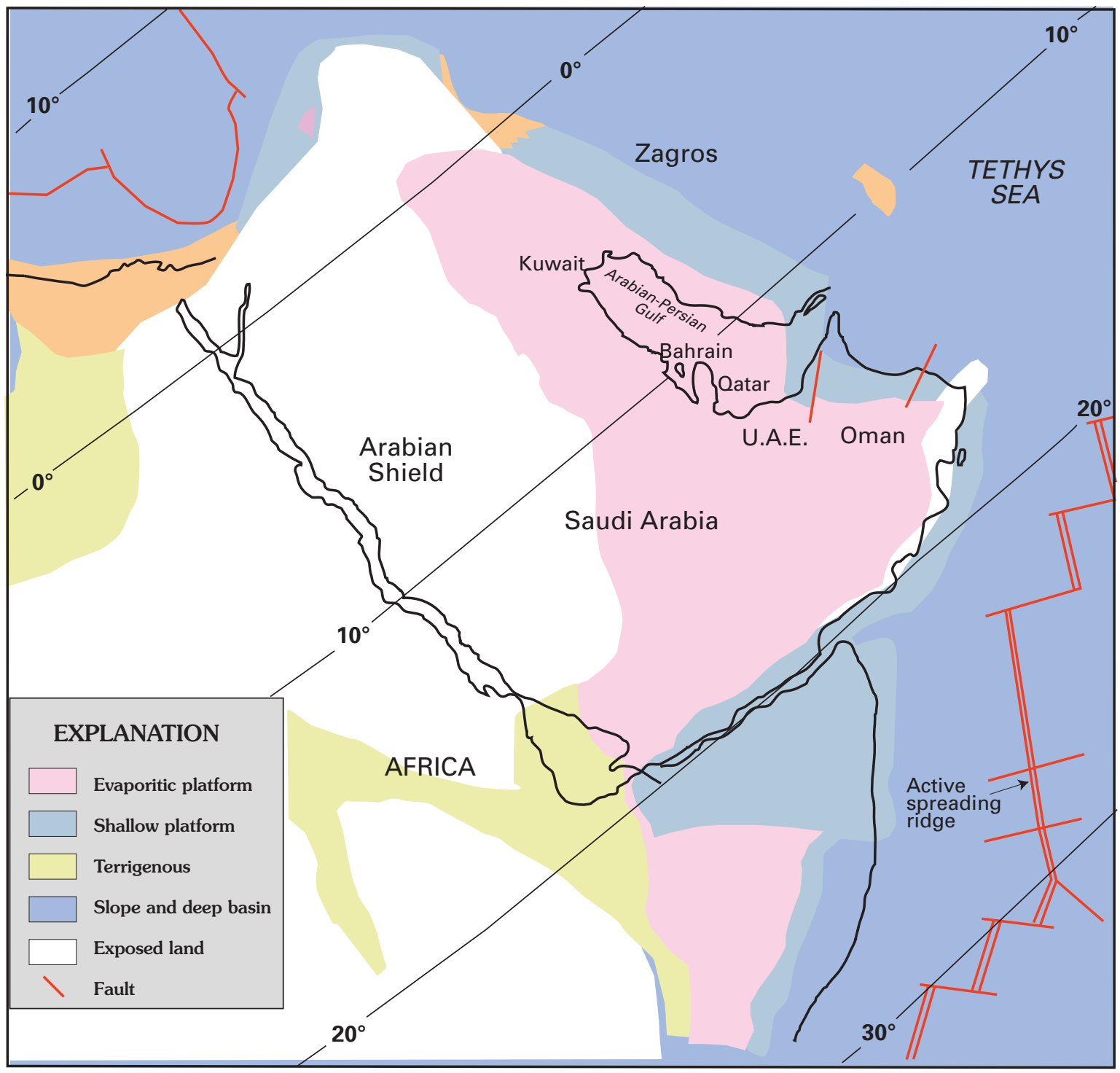

Figure 38. Paleoenvironment and tectonic reconstruction of the Late Jurassic, late Tithonian of the Arabian Plate. By the Tithonian, a series of rift basins had formed and separation from Africa had occurred. Modified from Al-Husseini (1998) and Fourcade and others (1993). U.A.E., United Arab Emirates.

these reservoirs. At Abqaiq field (fig. 32), the Hanifa is separated from the Arab D reservoir by more than $135 \mathrm{~m}$ of finegrained, impermeable carbonates of the Jubailah Formation. The Hanifa source facies is overlain by as much as $106 \mathrm{~m}$ of the Hanifa reservoir facies, which is in pressure-fluid communication with the Arab D by means of a network of fractures through the Jubailah Formation (fig. 1) (Grover, 1993).

The upper portion of the Tuwaiq Mountain Formation contains a succession of carbonate grainstones, particularly at Berri field, Saudi Arabia (fig. 32), that is referred to as the Hadriya reservoir facies. The Hadriya reservoirs consist of a basinward succession of coarse-grained, storm-related, skeletal and algal grainstone shoal deposits (Koepnick and others, 1995; Kompanick and others, 1995). The north-southoriented, wedge-shaped accumulation ranges from 15 to 70 $\mathrm{m}$ in thickness and contains seven wedge-shaped, 5 to $9 \mathrm{~m}$ upward-coarsening packages. Performance of Hadriya reservoirs is affected by both depositional and diagenetic processes. The reservoir structure is multilayered and internally heterogeneous owing to the Hadriya's sequence framework and depositional and diagenetic processes that created horizontal and vertical barriers to fluid flow. Shallow-burial, bed-parallel diagenesis produced cementation at the tops of parasequences impeding vertical cross-flow of fluids within the reservoir. In contrast, later cross-cutting diagenetic modifications, which include some intragranular microporosity development and 
sparry intergranular cementation, resulted in a major reduction in permeability. The best producing horizons are algal grainstones that exhibit lesser depositional heterogeneity and greater preservation of primary porosity (Koepnick and others, 1995). Low-permeability lime mudstones of the lower Hanifa Formation provide a seal for the underlying Hadriya reservoir.

\section{Seal Rocks}

Seal rocks for the major Arab Formation carbonate-rock reservoirs of the Arabian Sub-Basin Tuwaiq/Hanifa-Arab TPS are anhydrite beds of the Arab and Hith Formations; secondary carbonate-rock reservoirs of the Upper Jurassic Hanifa and Jubailah Formations are sealed by overlying fine-grained, impermeable carbonate rocks or shales of adjacent formations (Alsharhan and Nairn, 1997). Anhydrite beds of the Arab and Hith Formations form an excellent cap for the giant oil and associated gas accumulations in the Arab carbonate rocks. Moreover, upward seepage through these caps is rare and has occurred only as a result of major faulting over a structure or from lateral thinning or wedging out of the anhydrites.

In the Arabian-Persian Gulf region, the Arab Formation is overlain by the Upper Jurassic Hith Formation (Murris, 1980; Ayres and others, 1982; Al-Husseini, 1997; Sharland and others, 2001; Zeigler, 2001). A latest Jurassic restrictedshelf, evaporitic environment resulted in the deposition of the massive, regionally extensive Hith Formation evaporite (fig. 38, evaporitic platform). The Hith evaporite forms a regional seal for Jurassic reservoirs (Murris, 1980; Yousif and Nouman, 1997; Al-Husseini, 1997) and thus is the regional seal for the Arabian Sub-Basin Tuwaiq/Hanifa-Arab TPS of this report.

The Tithonian Stage of the Upper Jurassic was dominated by evaporites and shallow marine carbonate rocks that compose the "Arab sequence." The Arab sequence corresponds to the Arab reservoirs and evaporites (Arab A through D) and the Hith Formation evaporites (fig. 14). According to Al-Husseini (1997), the complete Arab sequence consists of (1) shallowing-upward, shoal-grainstone (transgressive deposits); (2) bedded lagoonal mud/wackestone (maximum flooding surface); (3) coarse bioclastic grainstone capped by algal laminates (early highstand); and (4) anhydrites (later highstand). Two evaporite/salt inland "salinas" (salt lakes) developed in the western Rub 'al Khali Basin and Jurassic Gotnia intraplatform sub-basin (Al-Husseini, 1997).

Murris (1980) described Hith evaporite development on a shallow platform in a sabkha environment due to an arid climate in the late Turonian. Alsharhan and Kendall (1986) suggested that the predominance of anhydrite and the occurrence of minor dolomite in the Hith Formation mark a final regressive, prograding supratidal phase of Late Jurassic sedimentation. They interpret the Upper Jurassic cycles of marine limestone and anhydrites of the Arab and Hith Formations as a response to changes in sea level caused by regional epeirogenic movements or by eustasy.
The Upper Jurassic Hith Formation consists of perhaps a hundred meters of massive beds of anhydrite showing chicken-wire texture with subordinate interbeds of light- to dark-colored dolomites (Alsharhan and Kendall, 1994). The Arab members A, B, and C consist mostly of anhydrite with chicken-wire texture and subordinate dolomite and limestone. The Arab D member is mostly limestone and dolomite with subordinate anhydrite. At Abqaiq field, the Hith anhydrite is 128 to $287 \mathrm{~m}$ in thickness; the anhydrites of the Arab B and C anhydrite sub-members are each about $21 \mathrm{~m}$ in thickness and the Arab D is about $15 \mathrm{~m}$ (Saner and Abdulghani, 1995). At Ghawar field, the Hith Formation is about $152 \mathrm{~m}$ thick and consists of anhydrite with subordinate fine-grained limestone and dolomite (Arabian American Oil Company, 1959). The anhydrite lithofacies of the Arab D at Ghawar field consists of nodular to massive anhydrite, commonly with chicken-wire texture (Al-Husseini, 1997; Cantrell and others, 2001).

The seals for Hanifa reservoirs are fine-grained carbonate rocks that commonly leak because of fractures (Alsharhan and Nairn, 1997). For example, at Abqaiq field the Hanifa reservoir is separated from the giant Arab D reservoir by more than $137 \mathrm{~m}$ of fine-grained, impermeable carbonate rock of the Jubailah Formation, which appears to provide the seal. However, this carbonate-rock seal is in places ineffective from microfracturing that causes the Hanifa and Arab D reservoirs to be in pressure-fluid communication (Grover, 1993). Low-permeability mudstones of the lower Hanifa Formation provide a seal for the underlying Hadriya reservoirs of the Tuwaiq Mountain Formation; this reservoir/seal relation is best developed at Berri field (McGuire and others, 1993).

\section{Traps and Trap Styles}

Traps and trap styles of the Arabian Sub-Basin Tuwaiq/ Hanifa-Arab TPS are similar to those discussed in the equivalent "Traps and Trap Styles" section for the Central Arabia Qusaiba-Paleozoic TPS. Basement structures in the area of the Central Arabian intraplatform sub-basin controlled much of the deposition and subsequent structural growth during the Jurassic. Traps include (1) anticlines related to basement block faulting; (2) domes from tectonic salt pillows or other halokinetic deformation; (3) combined structural traps such as salt-assisted fault block traps; (4) combined structural/stratigraphic (facies) traps (Alsharhan and Nairn, 1997). Major trap formation and modification of the Arabian Sub-Basin Tuwaiq/Hanifa-Arab TPS are a result of the First (Early) and Second (Late) Alpine Orogenic Events of Oman (figs. 1 and 31). The Early Alpine Orogeny during the Late Cretaceous was associated with the collision event that led to the emplacement of the Semail Ophiolite Complex in Oman, and the Late Alpine Orogeny during the middle to late Tertiary was associated with the opening of the Red Sea and collision of Arabia and Eurasia (Wender and others, 1998). 


\section{Assessment Unit Description, Geologic Models, and Assessment Results}

\section{Central Arabia Qusaiba-Paleozoic TPS}

The Central Arabia Qusaiba-Paleozoic TPS is divided into two assessment units: (1) a southern, onshore unit is called the Central Arch Horst-Block Anticlinal Oil and Gas AU (20210101); (2) the North Gulf Salt Basin Structural Gas AU (20210102) encompasses the northeast half of the TPS that is underlain by the Hormuz Salt (figs. 3 and 15).

\section{Central Arch Horst-Block Anticlinal Oil and Gas AU (20210101)}

In the geologic model for the Central Arch Horst-Block Anticlinal Oil and Gas Assessment Unit, hydrocarbons are sourced by the organic-rich basal shale of the Qusaiba Formation and produced from sandstone reservoirs. The primary reservoirs are eolian and fluvial sandstones of the Lower Permian Unayzah Formation and shallow marine shelf sandstones of the Devonian Jauf Formation; some production also comes from Ordovician sandstones in the northern and western portion of the Central Arch Horst-Block Anticlinal Oil and Gas AU. Light sweet oils with high $\left(44^{\circ}-53^{\circ}\right)$ API gravities and non-associated gas are produced in the central Arabian fields (fig. 19) along the western portion of the assessment unit and on the Central Arabian Arch. In the western area of the assessment unit, gas and mature oils migrated westward and updip from a more thermally mature eastern source area to the south of Ghawar (figs. 25 and 26). Gas is also produced in several fields in horst-block anticlines within the assessment unit, particularly at Ghawar and surrounding structures. The primary regional seal, the Permian Khuff Formation, is a combination of shale, tight carbonate rocks, and anhydrite.

The geologic model includes multiple styles of trap formation as follows: (1) a north-south structural grain where anticlines formed by sediments draping over reactivated basement horst blocks (fig. 39); (2) in the central Arabian fields, wrench faulting and associated drape- and drag-structures; and (3) stratigraphic pinch-out traps in Unayzah sandstones along the western margin of the assessment unit.

Characteristics of the discovered and undiscovered fields of the Central Arch Horst-Block Anticlinal Oil and Gas AU are shown in the input data form of Appendix 1; assessment results for the Central Arch Horst-Block Anticlinal Oil and Gas AU are summarized in table 1. Allocations of undiscovered resources to provinces, countries, and onshore or offshore areas are reported in U.S. Geological Survey World Energy Assessment Team (2000). Details on the USGS data input sheets and assessment model and methodology are described in Schmoker and Klett (2000). A summary of historic exploration and production data of known and grown volumes for fields of the Central Arch Horst-Block Anticlinal Oil and Gas AU is shown in figures 40 through 42 and in table 2; additional graphs and tables for this assessment unit are found in U.S. Geological Survey World Energy Assessment Team (2000).

Since the first discoveries in 1973, through the last discovery reported in the Petroconsultants (1996a) database to 1995,14 oil fields and 4 gas fields of minimum size ( $>20$ MMBO and 120 BCFG, respectively) constitute the total known discoveries within the assessment unit (Appendix 1 and table 2). Cumulative known oil volume and gas volume from the 14 oil fields and 4 gas fields are about $6.2 \mathrm{BBO}$ and 12.1 TCF of gas (table 2); however, cumulative grown volumes are estimated at nearly $12.6 \mathrm{BBO}$ and $25.8 \mathrm{TCF}$ (table 2), respectively. The largest oil field in the assessment unit has an estimated known volume of about $2 \mathrm{BBO}$ and a grown volume of nearly $4 \mathrm{BBO}$ (fig. 40). The range in known volume size of the remaining 13 oil fields is between about $70 \mathrm{MMBO}$ and $600 \mathrm{MMBO}$, and the corresponding range in grown size volumes between about $90 \mathrm{MMBO}$ and $1.5 \mathrm{BBO}$, respectively (fig. 40). The largest discovered gas field has a known gas volume of about $750 \mathrm{BCF}$ and grown gas volume of about 2.4 TCF (fig. 41); the smallest of the four discovered gas fields has a known gas volume of about $300 \mathrm{BCF}$ and a corresponding grown volume of about 1 TCF (fig. 41).

The historical exploration data of figure 42 show that of the 18 new-field wildcats reported in Petroconsultants (1996a), 14 were drilled in a 6-year period from 1989 to 1995. During that 6-year period, 10 oil fields and 4 gas fields greater than the minimum size (totaling 14) were discovered (fig. 42), which results in an apparent success ratio of 1.0. The surge in exploration and consequent new-field discoveries reflects a new play concept and resulting discoveries of oil and gas fields in central Saudi Arabia (fig. 19); the high apparent success in exploration was probably guided by 3-D seismic surveys.

The input data for assessment of the Central Arch HorstBlock Anticlinal Oil and Gas AU are shown in Appendix 1. For this assessment unit, a minimum field size of $20 \mathrm{MMBO}$ and the equivalent 120 BCFG was used for undiscovered oil and gas fields, respectively. This specific minimum field size was determined after reviewing the historical data and exploration trends for the region and represents an estimated minimum economic field size over the assessment forecast period of 30 years.

The historic production data indicate that the median size of grown oil fields has changed through time, as displayed in discovery thirds on the input data sheet (first page of data form, Appendix 1 and table 2). The median size of grown oil fields changed from $760 \mathrm{MMBO}$ for the first five fields (first discovery third), to $976 \mathrm{MMBO}$ for the second five discovered oil fields (second discovery third), to $539 \mathrm{MMBO}$ for the four oil fields respresenting the last discovery third (table 2). This assessment estimates a median grown size for undiscovered oil fields of $100 \mathrm{MMBO}$ for the Central Arch Horst-Block 


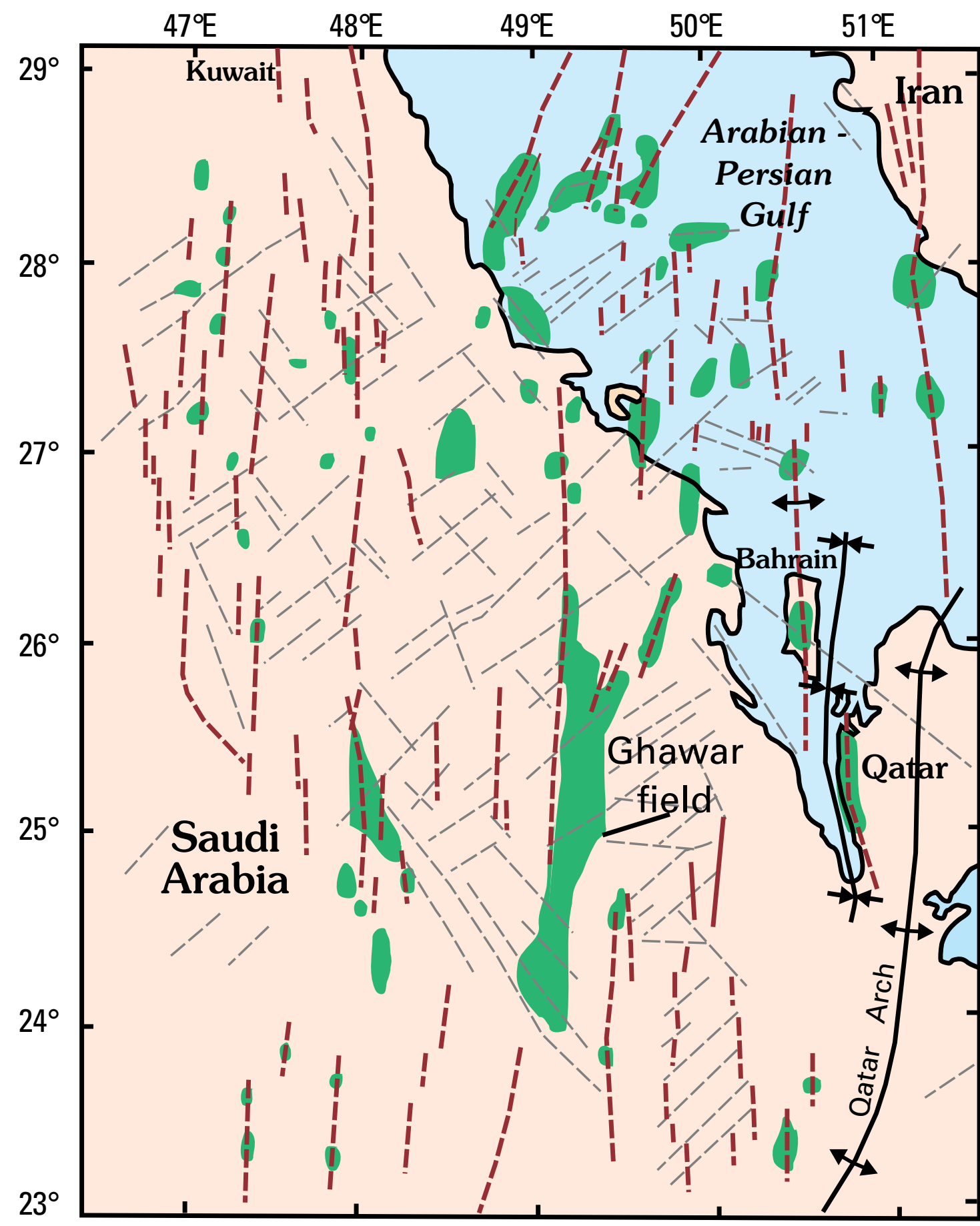

\section{EXPLANATION}

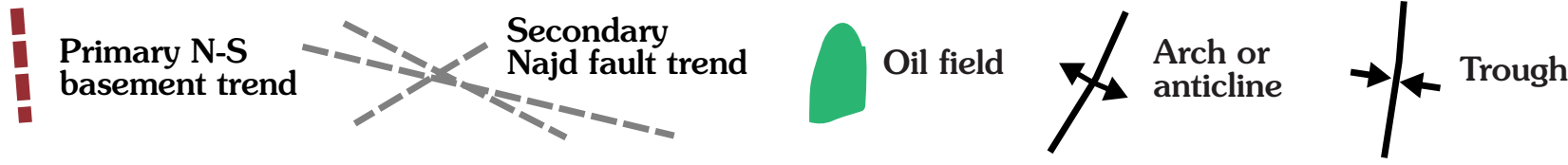

Figure 39. General structural trends of Greater Ghawar Uplift and surrounding area, showing primary north-south direction of basement and secondary trend due to Najd Fault system. Note how many of the major oil fields align with structures. Modified from Al Khatieb and Norman (1982) and Edgell (1992). 
Table 1. Assessment summary for Central Arabia Qusaiba-Paleozoic Total Petroleum System (202101).

[MMBO, million barrels of oil. BCFG, billion cubic feet of gas. MMBNGL, million barrels of natural gas liquids. MFS, minimum field size assessed (MMBO or BCFG). Prob., probability (including both geologic and accessibility probabilities) of at least one field equal to or greater than the MFS. Results shown are fully risked estimates. For gas fields, all liquids are included under the NGL (natural gas liquids) category.

F95 represents a 95 percent chance of at least the amount tabulated. Other fractiles are defined similarly. Fractiles are additive under the assumption of perfect positive correlation. Shading indicates not applicable

202101 Total: Central Arabia Qusaiba Paleozoic Total Petroleum System

\begin{tabular}{|c|c|c|c|c|c|c|c|c|c|c|c|c|c|c|}
\hline \multirow{3}{*}{$\begin{array}{c}\text { Code } \\
\text { and Field } \\
\text { Type }\end{array}$} & \multirow{3}{*}{ MFS } & \multirow{3}{*}{$\begin{array}{l}\text { Prob. } \\
(0-1)\end{array}$} & \multicolumn{12}{|c|}{ Undiscovered Resources } \\
\hline & & & \multicolumn{4}{|c|}{ Oil (MMBO) } & \multicolumn{4}{|c|}{ Gas (BCFG) } & \multicolumn{4}{|c|}{ NGL (MMBNGL) } \\
\hline & & & F95 & F50 & F5 & Mean & F95 & F50 & F5 & Mean & F95 & F50 & F5 & Mean \\
\hline
\end{tabular}

\begin{tabular}{|c|c|c|c|c|c|c|c|c|c|c|c|c|c|}
\hline Oil Fields & 1.00 & 7,301 & 18,596 & 32,829 & 19,190 & 10,587 & 27,514 & 51,123 & 28,756 & 586 & 1,599 & 3,281 & 1,723 \\
\hline Gas Fields & 1.00 & & & & & 141,919 & 345,140 & 599,554 & 354,583 & 8,729 & 21,994 & 39,905 & 22,864 \\
\hline Total & 1.00 & 7,301 & 18,596 & 32,829 & 19,190 & 152,506 & 372,654 & 650,677 & 383,339 & 9,316 & 23,592 & 43,186 & 24,587 \\
\hline
\end{tabular}

$20210101 \quad$ Central Arch Horst-Block Anticlinal Oil and Gas Assessment Unit

\begin{tabular}{|c|c|c|c|c|c|c|c|c|c|c|c|c|c|c|c|c|c|c|}
\hline \multirow{3}{*}{$\begin{array}{l}\text { Field } \\
\text { Type }\end{array}$} & \multirow{3}{*}{ MFS } & \multirow{3}{*}{\begin{tabular}{|c} 
Prob. \\
$(0-1)$ \\
\end{tabular}} & \multicolumn{12}{|c|}{ Undiscovered Resources } & \multirow{2}{*}{\multicolumn{4}{|c|}{$\begin{array}{l}\text { Largest Undiscovered Field } \\
\text { (MMBO or BCFG) }\end{array}$}} \\
\hline & & & \multicolumn{4}{|c|}{ Oil (MMBO) } & \multicolumn{4}{|c|}{ Gas (BCFG) } & \multicolumn{4}{|c|}{ NGL (MMBNGL) } & & & & \\
\hline & & & F95 & $\mathrm{F} 50$ & $\mathrm{~F} 5$ & Mean & F95 & $\mathrm{F} 50$ & $\mathrm{~F} 5$ & Mean & F95 & $\mathrm{F} 50$ & $\mathrm{~F} 5$ & Mean & F95 & $\mathrm{F} 50$ & F5 & Mean \\
\hline Oil Fields & 20 & 100 & 7,301 & 18,596 & 32,829 & 19,190 & 10,587 & 27,514 & 51,123 & 28,756 & 586 & 1,599 & 3,281 & 1,723 & 830 & 1,927 & 4,185 & 2,141 \\
\hline Gas Fields & 120 & & & & & & 79,478 & 199,003 & 333,005 & 201,631 & 6,238 & 15,742 & 27,327 & 16,138 & 8,557 & 20,215 & 42,897 & 22,212 \\
\hline Total & & 1.00 & 7,301 & 18,596 & 32,829 & 19,190 & 90,066 & 226,517 & 384,128 & 230,387 & 6,824 & 17,341 & 30,608 & 17,861 & & & & \\
\hline
\end{tabular}

$20210102 \quad$ North Gulf Salt Basin Structural Gas Assessment Unit

\begin{tabular}{|c|c|c|c|c|c|c|c|c|c|c|c|c|c|c|c|c|c|c|}
\hline \multirow{3}{*}{$\begin{array}{l}\text { Field } \\
\text { Type }\end{array}$} & \multirow{3}{*}{ MFS } & \multirow{3}{*}{$\begin{array}{c}\text { Prob. } \\
(0-1)\end{array}$} & \multicolumn{12}{|c|}{ Undiscovered Resources } & \multirow{2}{*}{\multicolumn{4}{|c|}{$\begin{array}{l}\text { Largest Undiscovered Field } \\
\text { (MMBO or BCFG) }\end{array}$}} \\
\hline & & & \multicolumn{4}{|c|}{ Oil (MMBO) } & \multicolumn{4}{|c|}{ Gas (BCFG) } & \multicolumn{4}{|c|}{ NGL (MMBNGL) } & & & & \\
\hline & & & F95 & F50 & F5 & Mean & F95 & F50 & F5 & Mean & F95 & F50 & F5 & Mean & F95 & F50 & F5 & Mean \\
\hline Oil Fields & 20 & 1.00 & 0 & 0 & 0 & 0 & 0 & 0 & 0 & 0 & 0 & 0 & 0 & & & NA & NA & NA \\
\hline Gas Fields & 120 & & & & & & 62,441 & 146,137 & 266,549 & 152,952 & 2,491 & 6,251 & 12,578 & 6,727 & 7,840 & 19,683 & 48,051 & 22,624 \\
\hline Total & & 1.00 & 0 & 0 & 0 & 0 & 62,441 & 146,137 & 266,549 & 152,952 & 2,491 & 6,251 & 12,578 & 6,727 & & & & \\
\hline
\end{tabular}




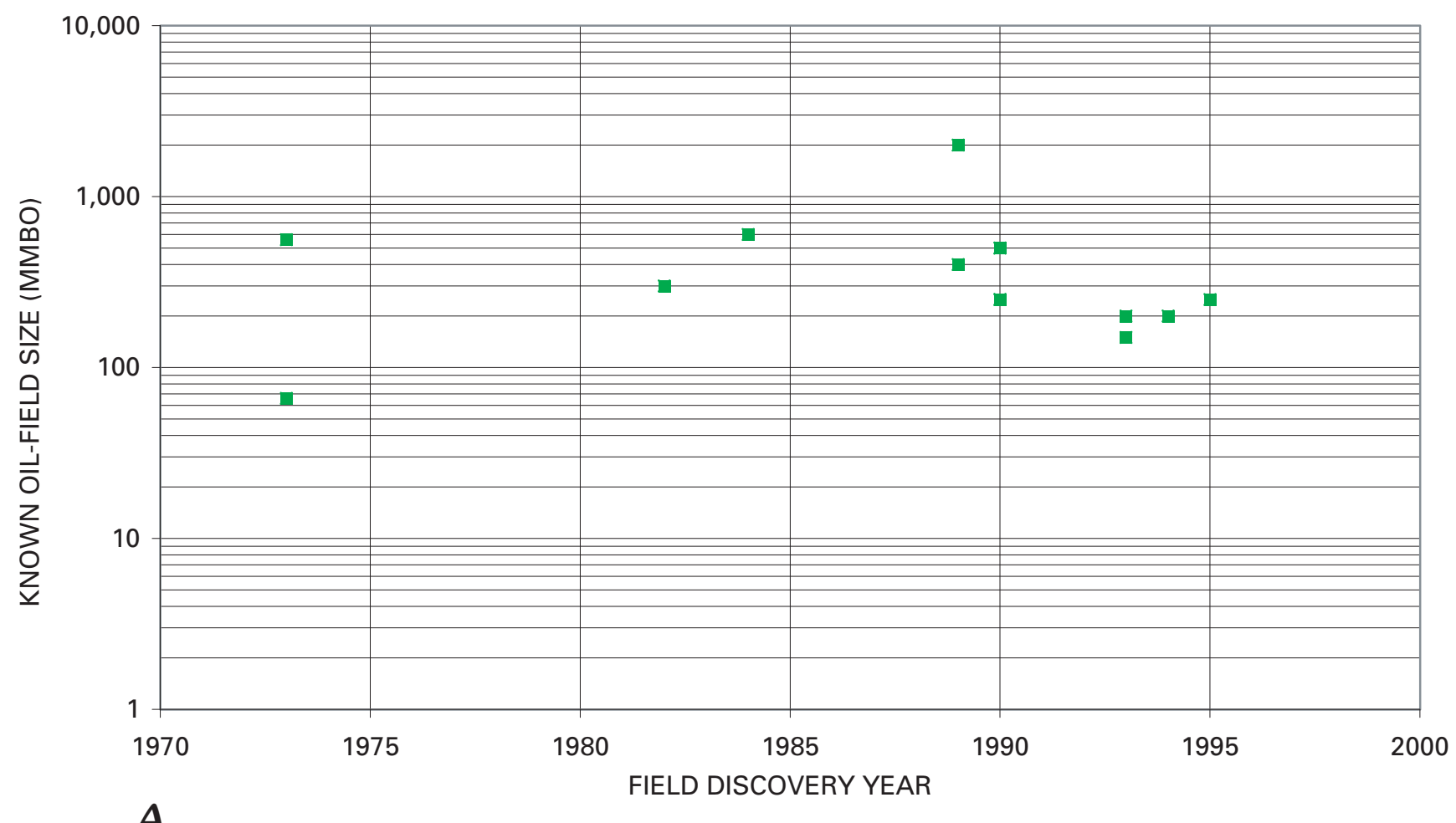

A

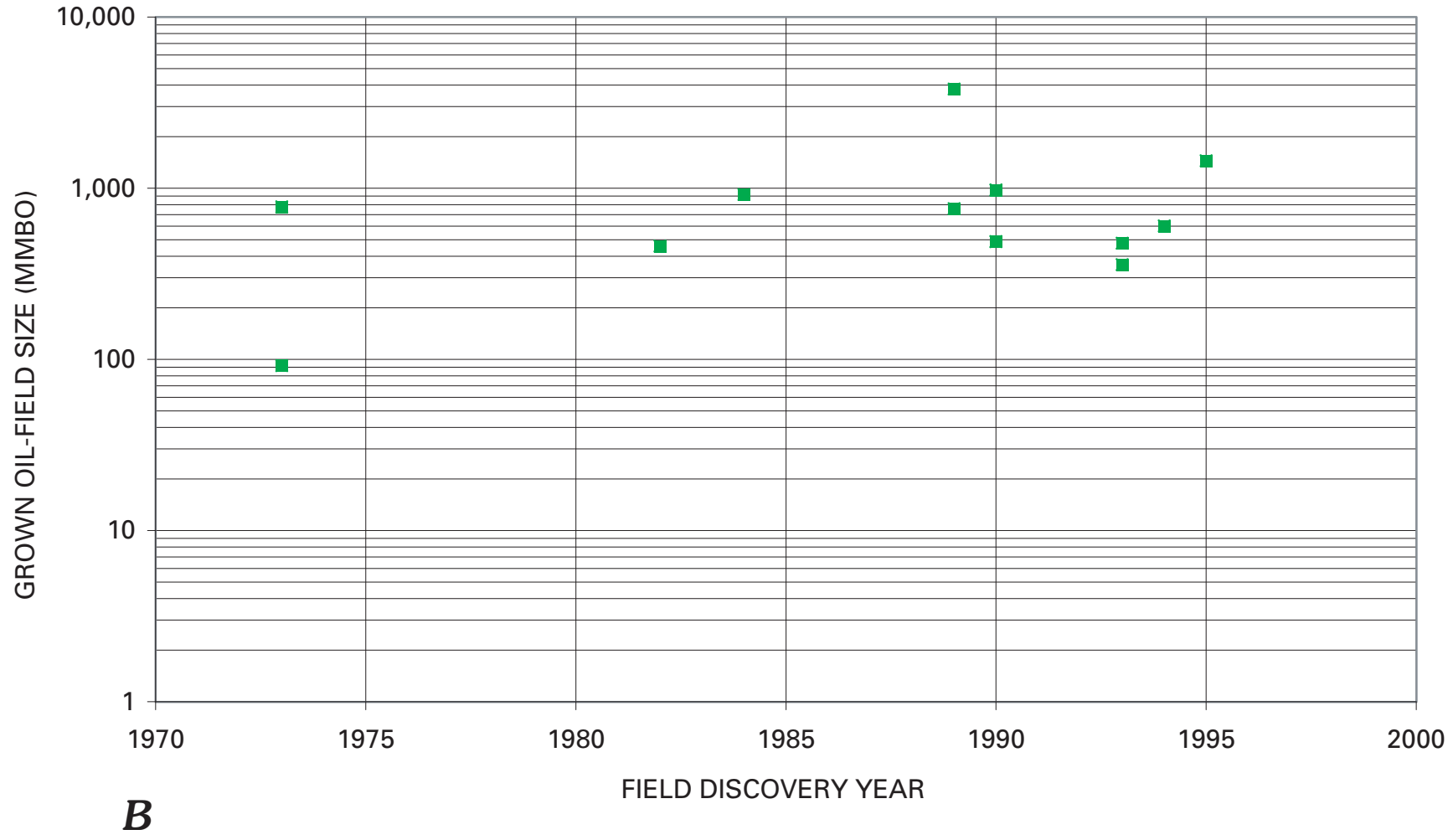

Figure 40. Plots of $A$, known oil-field size, and $B$, grown oil-field size versus field discovery year for Central Arch Horst-Block Anticlinal Oil and Gas Assessment Unit (20210101). Data derived and modified from Petroconsultants (1996a, b). MMBO, million barrels of oil. 

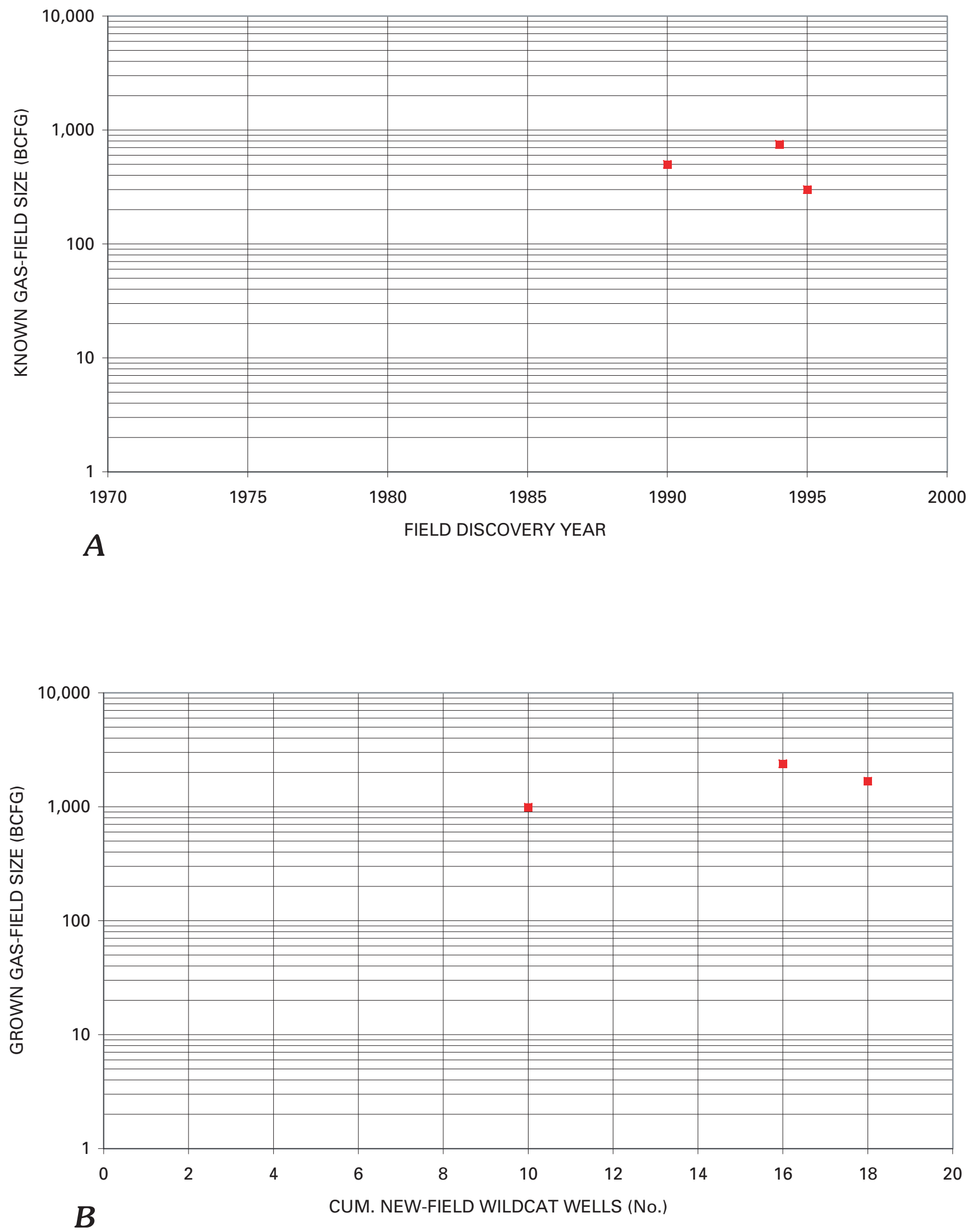

Figure 41. Plots of $A$, known gas-field size versus field discovery year, and $B$, grown gas-field size versus cumulative (CUM.) number (No.) of new-field wildcat wells for Central Arch Horst-Block Anticlinal Oil and Gas Assessment Unit (20210101). Data derived and modified from Petroconsultants (1996a, b). BCFG, billion cubic feet of gas. 


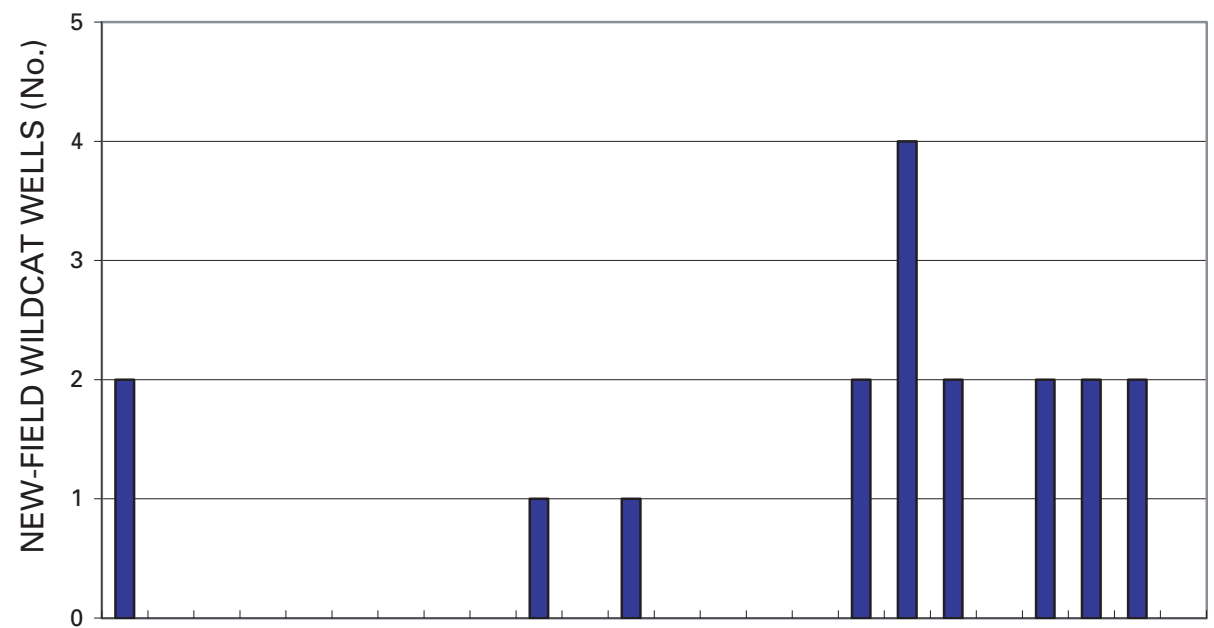

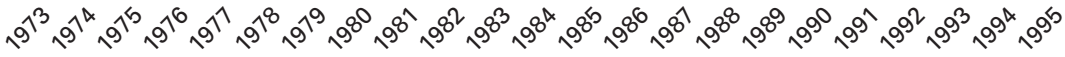
A

DRILLING COMPLETION YEAR
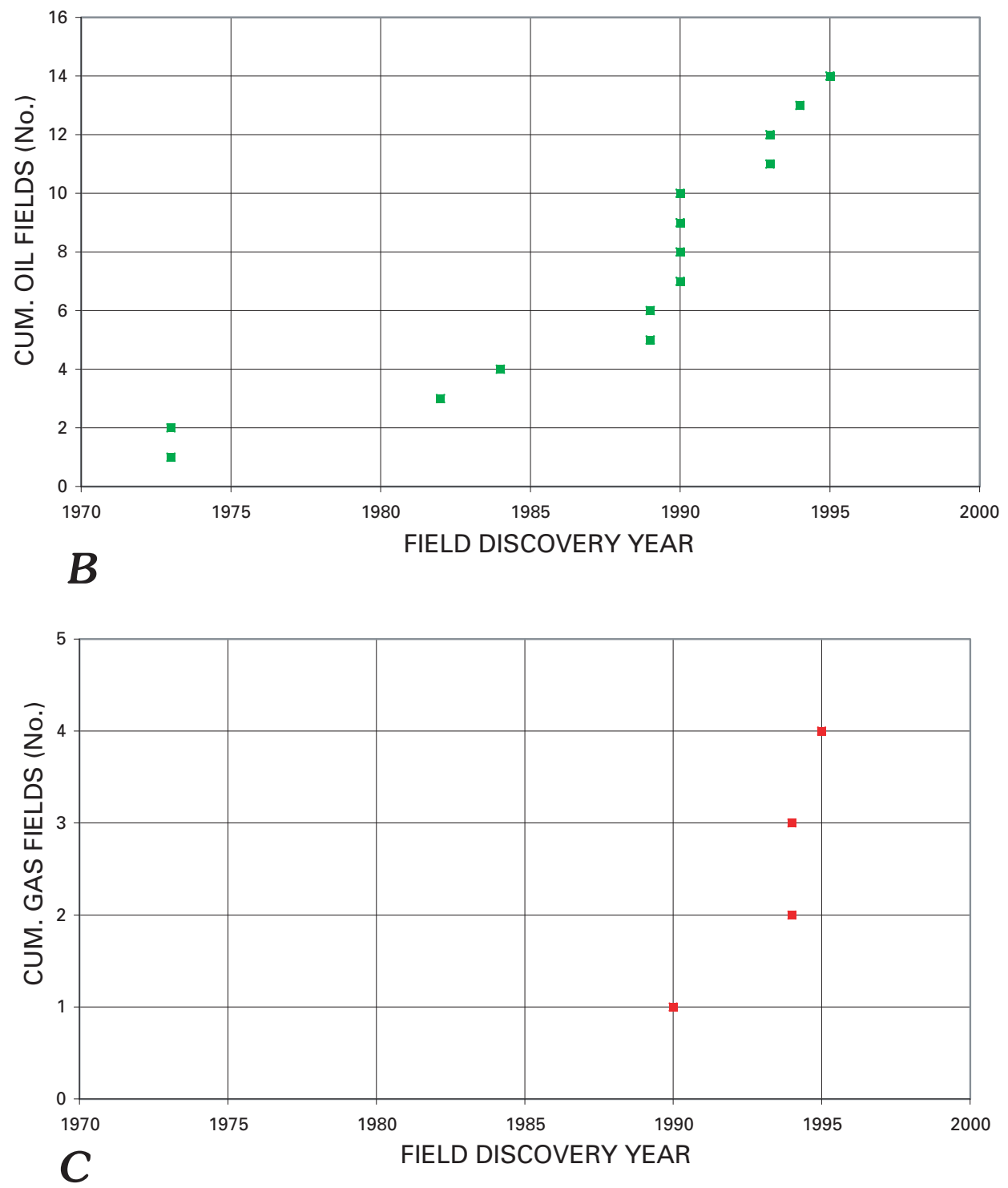
Anticlinal Oil and Gas AU (Appendix 1). The median field size of undiscovered fields in the assessment unit is generally expected to decrease with time, as is the case for most basins worldwide.

For the minimum number of oil fields, this assessment estimates that at least 15 oil fields greater than minimum size would be discovered in the assessment unit (Appendix 1). Although only 14 oil fields of minimum size have been discovered through 1999, much opportunity for exploration remains for reservoirs outside of the main trend. It is estimated here that the median number of oil fields to be discovered in the assessment unit, at the minimum size, over the next 30 years is 90 fields, with a maximum of 180 fields to be discovered (Appendix 1).

Co-product ratios, such as the gas/oil ratio (GOR) and the natural gas liquids (NGL)/gas ratio (LGR) for oil fields, are important because the USGS methodology uses these ratios to calculate gas in oil fields and NGL in oil fields. These coproduct ratios are critical and can have significant implications for the economic viability of fields, especially small fields. The co-product ratios are given in Appendix 1 for the Central Arch Horst-Block Anticlinal Oil and Gas AU. Other ancillary data, such as API gravity, sulfur content, drilling depths, and water depth are also shown on the input form (Appendix 1).

Gas fields were assessed in a similar manner as oil fields. Only four gas fields of minimum size have been discovered over the period from 1990 to 1995 ; therefore, historical exploration data are limited in both time and number. Median grown field size for the four gas fields is 2,033 BCFG (table 2 ). This assessment anticipates a median size for undiscovered gas fields of $700 \mathrm{BCFG}$, and at least 20 fields of minimum size will be discovered for the Central Arch Horst-Block Anticlinal Oil and Gas AU (Appendix 1). Estimated median number of gas fields to be discovered in the assessment unit, at the minimum size over the next 30 years, is 120 fields, with a maximum of 220 fields to be discovered (Appendix 1). Recent reports show that at least four additional new gas fields (Niban, Shaden, Manjurah, and South Tinat) have been discovered within the Greater Ghawar Uplift Province (2021), and within the Central Arch Horst-Block Anticlinal Oil and Gas AU, subsequent to completion of the study by the U.S. Geological Survey World Energy Assessment Team (2000). (See Gulf PetroLink, 1999; Alhajji, 2000; Weekly Petroleum Argus, 2000.) Preliminary estimates of the cumulative known reserves for two of these newly discovered gas/condensate fields (Niban and Shaden) are about 4 TCFG and 6 BBNGL.

Figure 42 (preceding page). Historical exploration plots for Central Arch Horst-Block Anticlinal Oil and Gas Assessment Unit (20210101). A, Number (No.) of new-field wildcat wells versus drilling completion year; $B$, Cumulative (CUM.) number of oil fields versus field discovery year; $C$, Cumulative number of gas fields versus field discovery year. Data derived and modified from Petroconsultants (1996a, b).
A Monte Carlo simulation (Charpentier and Klett, 2000) provided the following results for the Central Arch HorstBlock Anticlinal Oil and Gas AU (table 1). Oil in undiscovered oil fields ranges from an F95 (95 percent chance) of $7.3 \mathrm{BBO}$ to an F5 (5 percent chance) of $32.8 \mathrm{BBO}$, with a mean volume of undiscovered oil of 19.2 BBO. In addition, the largest expected undiscovered oil field, at the mean, was calculated at about 2.1 BBO. Similarly, the results for undiscovered non-associated gas ranges from an F95 of about 79.5 TCF to an F5 of 333.0 TCF, with a mean volume of undiscovered gas in gas fields of about 201.6 TCF (table 1). The largest expected undiscovered gas field, at the mean, is about 22.2 TCF. The co-product ratios (Appendix 1) were used to calculate a range of associated gas in undiscovered oil fields from 10.6 TCF (F95) to 51.1 TCF (F5), with a mean volume of associated gas of $28.8 \mathrm{TCF}$ in undiscovered oil fields. The volume of NGL in oil fields was calculated in the range from 586 MMBNGL (F95) to 3.3 BBNGL (F5), with a mean NGL volume of 1.7 BBNGL in undiscovered oil fields (table 1).

In summary, a mean undiscovered volume of 19.2 BBO in conventional oil fields is anticipated for the Central Arch Horst-Block Anticlinal Oil and Gas AU (table 1). A total of about 12.6 BBO (grown) in oil fields has already been discovered (table 2), thus about 40 percent of the oil has been discovered in this assessment unit. In contrast, a mean undiscovered volume of about 201.6 TCF of gas in gas fields was estimated for the assessment (table 1). About 7.4 TCF of gas in gas fields was calculated as discovered grown reserves (table 2), suggesting that less than 4 percent of the gas in gas fields has been discovered in the Central Arch Horst-Block Anticlinal Oil and Gas AU. The largest undiscovered gas field estimated at the mean is about 22.2 TCF (table 1), an order of magnitude larger than the grown reserve volume in any of the discovered gas fields from the historical data. Although the discovered grown gas volume is minimal (4 percent) compared to the mean undiscovered volume (96 percent), large volumes of Silurian-sourced non-associated gas reserves are known to underlie the supergiant Jurassic oil fields, particularly Ghawar field. These gas volumes are considered to be reserves from field growth and not included as separate Paleozoic new gas-field discoveries. This is especially critical because the assessment process must not double-count fields when the area assessed contains stacked total petroleum systems.

In summary, we consider that gas exploration within the Central Arch Horst-Block Anticlinal Oil and Gas AU is at an immature stage, and that great potential remains particularly for new-field discoveries of Silurian-sourced gas in Paleozoic reservoirs over the next 30 years in block- and wrench-faulted structural traps in central Arabia. Also, discoveries of Paleozoic gas fields have been reported subsequent to the completion of the U.S. Geological Survey World Petroleum Assessment 2000. These newly discovered gas fields are in adjacent structures west and south of Ghawar field (Gulf PetroLink, 1999; Alhajji, 2000; Weekly Petroleum Argus, 2000). Numerous discoveries of large oil fields are also expected from this 
Table 2. Known and grown volumes of discovered petroleum and discovery-history sequence for Central Arch Horst-Block Anticlinal Oil and Gas Assessment Unit (20210101).

[MMBO, million barrels of oil. BCFG, billion cubic feet of gas. MMBNGL, million barrels of natural gas liquids. Fields containing less than 1 MMBO in oil fields or 6 BCFG in gas fields were not considered in the assessment. Fields were classified as oil or gas by the USGS. Fields without reported discovery dates were not included. The first half or third shows year of first field discovery as well as end of period. NA means not applicable and is shown for volumes where only one field is present. Calculated values may not be equal to the sums of the component values because numbers have been independently rounded]

\section{Known and grown volumes of petroleum}

\begin{tabular}{|c|c|c|c|c|c|c|c|c|}
\hline \multirow[b]{2}{*}{ Field Type } & \multicolumn{4}{|c|}{ Known (Discovered) Volumes } & \multicolumn{4}{|c|}{ Grown (Discovered) Volumes } \\
\hline & $\begin{array}{l}\text { Number } \\
\text { of Fields }\end{array}$ & Oil (MMBO) & Gas (BCFG) & NGL (MMBNGL) & $\begin{array}{l}\text { Number } \\
\text { of Fields }\end{array}$ & Oil (MMBO) & Gas (BCFG) & NGL (MMBNGL) \\
\hline
\end{tabular}

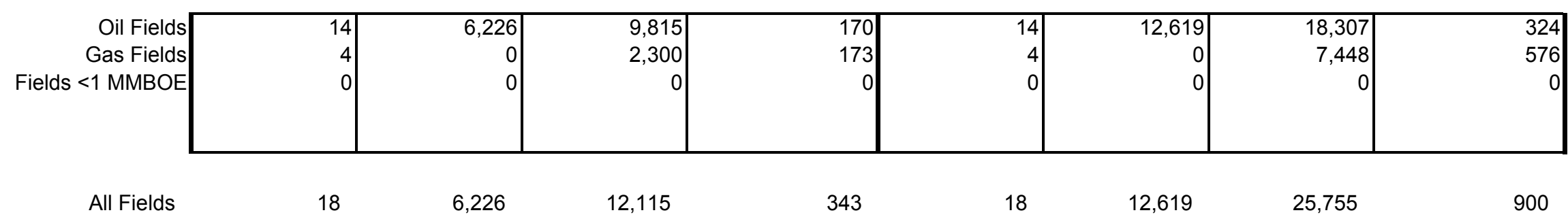

\section{Discovery-history sequence}

\begin{tabular}{|c|c|c|c|c|c|c|}
\hline \multirow[b]{2}{*}{$\begin{array}{l}\text { Field } \\
\text { Type }\end{array}$} & \multicolumn{6}{|c|}{ Discovery-History Sequence - Grown (Discovered) Volumes } \\
\hline & & $\begin{array}{c}\text { Year } \\
\text { (End of Period) }\end{array}$ & $\begin{array}{c}\text { Number of } \\
\text { Fields }\end{array}$ & $\begin{array}{c}\text { Total } \\
\text { Volume }\end{array}$ & $\begin{array}{l}\text { Mean } \\
\text { Size }\end{array}$ & $\begin{array}{l}\text { Median } \\
\text { Size }\end{array}$ \\
\hline \multirow[t]{5}{*}{ Oil Fields } & Grown Sizes (MMBO) & & & & & \\
\hline & First third & 1973-1989 & 5 & 3,010 & 602 & 760 \\
\hline & Second third & 1990 & 5 & 6,727 & 1,345 & 976 \\
\hline & Third third & 1995 & 4 & 2,882 & 720 & 539 \\
\hline & All Oil Fields & & 14 & 12,619 & 901 & 681 \\
\hline \multirow[t]{4}{*}{ Gas Fields } & Grown Sizes (BCFG) & & & & & \\
\hline & First half & 1990-1994 & 2 & 3,382 & 1,691 & 1,691 \\
\hline & Second half & 1995 & 2 & 4,066 & 2,033 & 2,033 \\
\hline & All Gas Fields & & 4 & 7,448 & 1,862 & 2,033 \\
\hline
\end{tabular}


assessment in less thermally mature areas within the TPS boundary and in wrench-faulted structural traps and stratigraphic pinch-out traps along the western flank of the basin. These areas for potential new discoveries are (1) to the west of Ghawar field and in the southernmost portion of the Widyan Basin-Interior Platform Province and Interior Homocline-Central Arch Province, and (2) to the south of Ghawar in a small northern portion of the Rub 'al Khali Basin Province (fig. 15).

\section{North Gulf Salt Basin Structural Gas AU (20210102)}

The North Gulf Salt Basin Structural Gas Assessment Unit is mostly in the northern Gulf offshore and within USGS Province 2023 (Mesopotamian Foredeep). In the geologic model for the North Gulf Salt Basin Structural Gas AU, hydrocarbons accumulated in structural traps that are mainly domes over salt diapirs and salt-assisted or salt-enhanced horst-block anticlines. In the North Gulf Salt Basin Structural Gas AU, the Qusaiba basal hot shale is primarily in the main zone of gas generation. Reservoirs consist mostly of cyclic grainstones and dolomitic shelf carbonate rocks of the Upper Permian Khuff Formation, with production controlled mainly by distribution and amount of anhydrite. Some fields in the assessment unit produce sour gas and other non-hydrocarbon gases. Many of the traps forming the fields of this assessment unit were created during post-Hercynian tectonic events, particularly during major uplift and erosion associated with the Late Cretaceous First Alpine Orogeny about 80 Ma (Loosveld and others, 1996).

Characteristics of the discovered and undiscovered fields of the North Gulf Salt Basin Structural Gas AU are shown in the input data form of Appendix 2; assessment results are summarized in table 1 . Only two known gas fields are assigned to the North Gulf Salt Basin Structural Gas AU: G-Structure and B-Structure gas fields in the northern Gulf offshore portion of Iran; these fields are indicated by the red dots in figure 15 . Both fields were discovered in 1966; they produce gas from the Khuff Formation. B-Structure gas field has an estimated recoverable reserve of $50 \mathrm{TCF}$ of gas (8.3 BBOE; Alsharhan and Nairn, 1997); median field size calculated from the two fields is $17.0 \mathrm{TCF}$.

For undiscovered gas fields, the following sizes of grown fields were assigned: (1) a minimum field size of $120 \mathrm{BCFG}$ (20 MMBOE); (2) a maximum field size of 60 TCF; and (3) a median size of 800 BCFG (Appendix 2). The number of undiscovered fields at the minimum field size was estimated as follows: a minimum of 20 , median of 75 , and maximum of 150 (Appendix 2). A Monte Carlo simulation provided the following results for the North Gulf Salt Basin Structural Gas AU: undiscovered non-associated gas ranges from an F95 of about 62.4 TCF to an F5 of 266.5 TCF, with a mean volume of undiscovered gas in gas fields of about 153.0 TCF (table 1). The largest expected undiscovered gas field at the mean was calculated at about 22.6 TCF. Using the liquids to gas ratio (Appendix 2), the volume of NGL in undiscovered gas fields was calculated to range from about 2.5 BBNGL (F95) to 12.6 BBNGL (F5), with a mean undiscovered volume of NGL of about 6.7 BBNGL (table 1). In summary, this assessment expects several large gas fields to be discovered during the next 30 years, most within the boundaries of Iran in the North Gulf offshore portion of the assessment unit, and within saltrelated structural traps.

\section{Arabian Sub-Basin Tuwaiq/Hanifa-Arab TPS}

The Arabian Sub-Basin Tuwaiq/Hanifa-Arab TPS, outlined in figure 30, is divided into two assessment units: (1) the Horst-Block Anticlinal Oil AU (20210201), and (2) the SaltInvolved Structural Oil AU (20210202).

\section{Horst-Block Anticlinal Oil AU (20210201)}

The Horst-Block Anticlinal Oil AU encompasses the onshore portion of the Arabian Sub-Basin Tuwaiq/HanifaArab TPS and is characterized by a primary north-south structural grain formed by the draping of sediments over reactivated basement fault blocks (fig. 39). These north-south structural features include the En Nala, Khurais-Burgan, and Maqalah anticlines (fig. 3). Jurassic fields within this assessment unit are Ghawar, Abqaiq, Khurais, Dhib, Bakr, El Haba, Suban, Jaladi, Jaham, Faridah, Lughfah, and Jawb fields, among several others (fig. 32).

Sourced by the Jurassic Tuwaiq Mountain and Hanifa Formations, mature oils averaging about $35^{\circ} \mathrm{API}$ gravity are produced from onshore central Arabian fields that accumulated mostly in cyclic, shallow-water, porous carbonate grainstones and packstones of the Upper Jurassic Arab Formation, particularly the Arab D reservoir.

Characteristics of the discovered and undiscovered fields of the Horst-Block Anticlinal Oil AU are shown in the input data form of Appendix 3; assessment results for undiscovered fields are summarized in table 3. A summary of historical exploration and production data of known and grown volumes for fields of the Horst-Block Anticlinal Oil AU is shown in figures 43 and 44 and in table 4; additional graphs and tables for this assessment unit are found in U.S. Geological Survey World Energy Assessment Team (2000).

Since the first discovery in 1940, through the last discovery in 1984, as reported in the Petroconsultants (1996a) database, 25 oil and no gas fields of minimum size ( $>20 \mathrm{MMBO}$ and $120 \mathrm{BCFG}$, respectively) constitute the total known discoveries within the assessment unit (Appendix 3 and table 4). Cumulative known oil volume and gas volume from the 25 oil fields are about $155.1 \mathrm{BBO}$ and 229.6 TCF, respectively, and cumulative grown volume for the assessment unit is estimated at nearly $196.6 \mathrm{BBO}$ of oil and $286.8 \mathrm{TCF}$ of gas (table 4). The largest discovered oil field in the Horst-Block Anticlinal Oil AU has an estimated known volume of about $110 \mathrm{BBO}$, and a grown volume of about $140 \mathrm{BBO}$ (fig. 43). This oil 

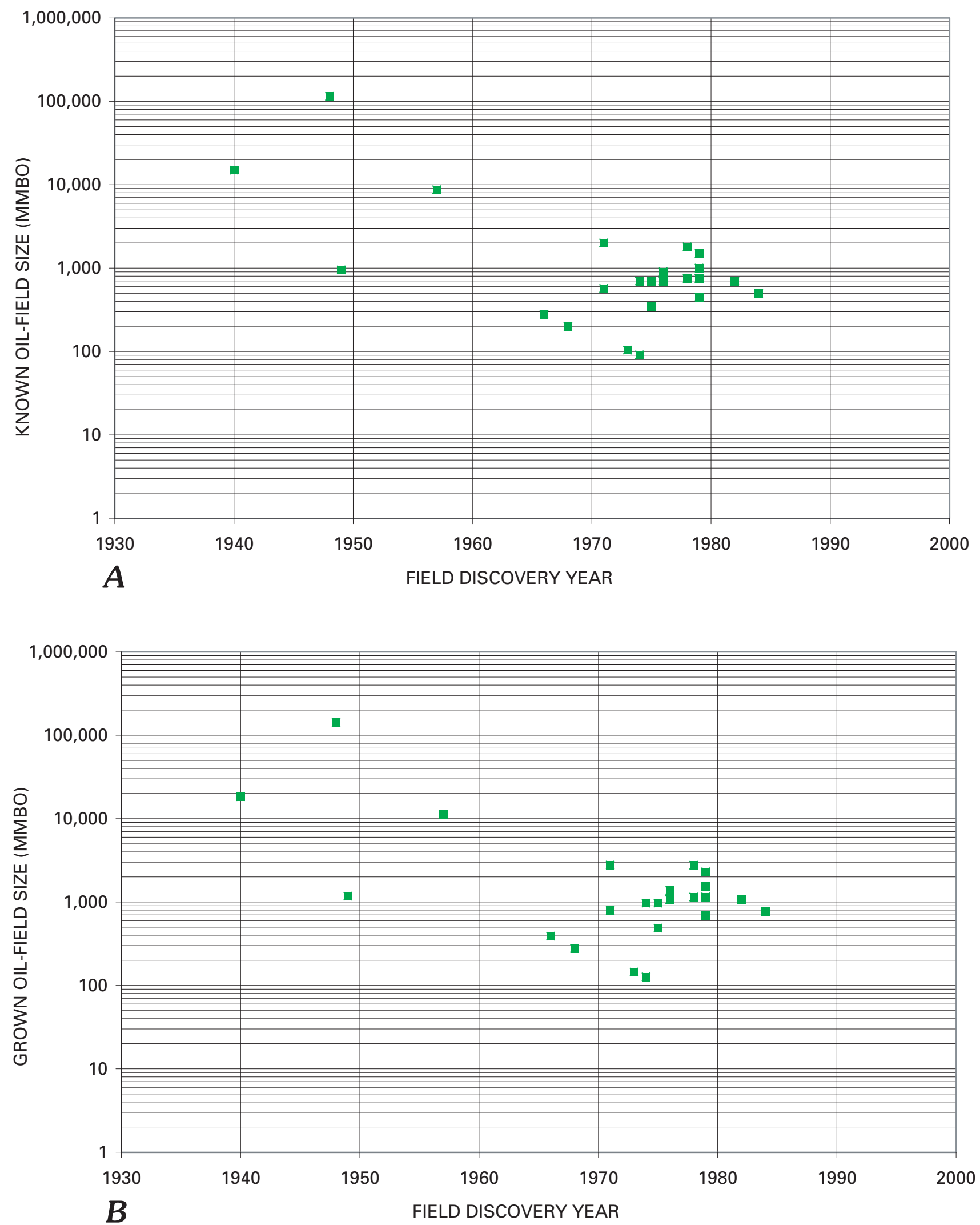

Figure 43. Plots of $A$, known oil-field size, and $B$, grown oil-field size versus field discovery year for Horst-Block Anticlinal Oil Assessment Unit (20210201) of Arabian Sub-Basin Tuwaiq/Hanifa-Arab Total Petroleum System. Data derived and modified from Petroconsultants (1996a, b). MMBO, million barrels of oil. 
Table 3. Assessment summary results for Arabian Sub-Basin Tuwaiq/Hanifa-Arab Total Petroleum System (202102).

[MMBO, million barrels of oil. BCFG, billion cubic feet of gas. MMBNGL, million barrels of natural gas liquids. MFS, minimum field size assessed (MMBO or BCFG). Prob., probability (including both geologic and accessibility probabilities) of at least one field equal to or greater than the MFS. Results shown are fully risked estimates. For gas fields, all liquids are included under the NGL (natural gas liquids) category. F95 represents a 95 percent chance of at least the amount tabulated. Other fractiles are defined similarly. Fractiles are additive under the assumption of perfect positive correlation. Shading indicates not applicable

\section{Total: Arabian Sub-Basin Tuwaiq/Hanifa-Arab Total Petroleum System}

\begin{tabular}{|c|c|c|c|c|c|c|c|c|c|c|c|c|c|c|}
\hline \multirow{3}{*}{$\begin{array}{c}\text { Code } \\
\text { and Field } \\
\text { Type }\end{array}$} & \multirow{3}{*}{ MFS } & \multirow{3}{*}{$\begin{array}{c}\text { Prob. } \\
(0-1)\end{array}$} & \multicolumn{12}{|c|}{ Undiscovered Resources } \\
\hline & & & \multicolumn{4}{|c|}{ Oil (MMBO) } & \multicolumn{4}{|c|}{ Gas (BCFG) } & \multicolumn{4}{|c|}{ NGL (MMBNGL) } \\
\hline & & & F95 & F50 & F5 & Mean & F95 & F50 & F5 & Mean & F95 & F50 & F5 & Mean \\
\hline
\end{tabular}

\begin{tabular}{|c|c|c|c|c|c|c|c|c|c|c|c|c|c|}
\hline Oil Fields & 100 & 16,992 & 40,829 & 69,390 & 41,703 & 13,258 & 32,782 & 58,994 & 34,046 & 489 & 1,273 & 2,545 & 1,362 \\
\hline Gas Fields & 1.00 & & & & & 0 & 0 & 0 & 0 & 0 & 0 & 0 & 0 \\
\hline Total & 1.00 & 16,992 & 40,829 & 69,390 & 41,703 & 13,258 & 32,782 & 58,994 & 34,046 & 489 & 1,273 & 2,545 & 1,362 \\
\hline
\end{tabular}

20210201 -- Horst-Block Anticlinal Oil Assessment Unit

\begin{tabular}{|c|c|c|c|c|c|c|c|c|c|c|c|c|c|c|c|c|c|c|}
\hline \multirow{3}{*}{$\begin{array}{l}\text { Field } \\
\text { Type }\end{array}$} & \multirow{3}{*}{ MFS } & \multirow{3}{*}{$\begin{array}{r}\text { Prob. } \\
(0-1)\end{array}$} & \multicolumn{12}{|c|}{ Undiscovered Resources } & \multirow{2}{*}{\multicolumn{4}{|c|}{$\begin{array}{l}\text { Largest Undiscovered Field } \\
\text { (MMBO or BCFG) }\end{array}$}} \\
\hline & & & \multicolumn{4}{|c|}{ Oil (MMBO) } & \multicolumn{4}{|c|}{ Gas (BCFG) } & \multicolumn{4}{|c|}{ NGL (MMBNGL) } & & & & \\
\hline & & & F95 & $\mathrm{F} 50$ & F5 & Mean & F95 & $\mathrm{F} 50$ & $\mathrm{~F} 5$ & Mean & F95 & $\mathrm{F} 50$ & F5 & Mean & F95 & F50 & F5 & Mean \\
\hline Oil Fields & 20 & 1.00 & 11,296 & 26,408 & 43,172 & 26,715 & 6,566 & 15,641 & 27,023 & 16,055 & 242 & 606 & 1,170 & 642 & 1,103 & 2,492 & 5,179 & 2,728 \\
\hline Gas Fields & 120 & & & & & & 0 & 0 & 0 & 0 & 0 & 0 & 0 & 0 & NA & NA & NA & NA \\
\hline Total & & 1.00 & 11,296 & 26,408 & 43,172 & 26,715 & 6,566 & 15,641 & 27,023 & 16,055 & 242 & 606 & 1,170 & 642 & & & & \\
\hline
\end{tabular}

20210202 -- Salt-Involved Structural Oil Assessment Unit

\begin{tabular}{|c|c|c|c|c|c|c|c|c|c|c|c|c|c|c|c|c|c|c|}
\hline \multirow{3}{*}{$\begin{array}{l}\text { Field } \\
\text { Type }\end{array}$} & \multirow{3}{*}{ MFS } & \multirow{3}{*}{$\begin{array}{r}\text { Prob. } \\
(0-1) \\
\end{array}$} & \multicolumn{12}{|c|}{ Undiscovered Resources } & \multirow{2}{*}{\multicolumn{4}{|c|}{$\begin{array}{l}\text { Largest Undiscovered Field } \\
\text { (MMBO or BCFG) }\end{array}$}} \\
\hline & & & \multicolumn{4}{|c|}{ Oil (MMBO) } & \multicolumn{4}{|c|}{ Gas (BCFG) } & \multicolumn{4}{|c|}{ NGL (MMBNGL) } & & & & \\
\hline & & & F95 & $\mathrm{F} 50$ & F5 & Mean & F95 & $\mathrm{F} 50$ & F5 & Mean & F95 & $\mathrm{F} 50$ & $\mathrm{~F} 5$ & Mean & F95 & $\mathrm{F} 50$ & F5 & Mean \\
\hline Oil Fields & 20 & 1.00 & 5,696 & 14,420 & 26,218 & 14,989 & 6,691 & 17,142 & 31,972 & 17,991 & 247 & 667 & 1,376 & 719 & 816 & 1,926 & 4,609 & 2,204 \\
\hline Gas Fields & 120 & & & & & & 0 & 0 & 0 & 0 & 0 & 0 & 0 & 0 & NA & NA & NA & NA \\
\hline Total & & 1.00 & 5,696 & 14,420 & 26,218 & 14,989 & 6,691 & 17,142 & 31,972 & 17,991 & 247 & 667 & 1,376 & 719 & & & & \\
\hline
\end{tabular}


field of such great resource volume is Ghawar field of Saudi Arabia. The known volume size range of the remaining 24 oil fields is between about $90 \mathrm{MMBO}$ and $15 \mathrm{BBO}$ with a median known field size of $1.5 \mathrm{BBO}$ (fig. 43).

The data for new-field wildcat wells in this assessment unit show that of the 35 new-field wildcats reported, 28 were drilled between 1963 and 1984 (fig. 44), during which 21 of the 25 oil fields greater than the minimum size were discovered. The data in figure 44 and figure 43 also suggest that the last new-field wildcat well was in 1984 when the last Jurassic oil field of the Horst-Block Anticlinal Oil AU was discovered.

The historical production data demonstrate a median grown size of oil fields in the assessment unit in discovery thirds as follows: first third (1940-1971, eight fields) is 1,980 MMBO; second third (1978, nine fields) is $973 \mathrm{MMBO}$, and third third (1984, eight fields) is 1,150 MMBO (table 4). The median size for undiscovered oil fields is estimated at 100 MMBO for the Horst-Block Anticlinal Oil AU (Appendix 3).

A median number of 120 undiscovered oil fields greater than minimum size is estimated for the assessment unit (Appendix 3). Although only 25 oil fields of minimum size have been discovered to date, these fields are comparatively very large. At a minimum size of $20 \mathrm{MMBO}$, this assessment predicts that numerous fields will be discovered over the next 30 years within the assessment unit. The minimum number of undiscovered fields is 25 , with a maximum number estimated at 215 fields. The maximum field size for undiscovered oil fields was estimated at 6 billion barrels (Appendix 3).

Monte Carlo simulation provided the following results for the Horst-Block Anticlinal Oil AU (table 3). Oil in undiscovered oil fields ranges from an F95 of about 11.3 BBO to an F5 of about $43.2 \mathrm{BBO}$, with a mean volume of undiscovered oil of $26.7 \mathrm{BBO}$. In addition, the expected largest undiscovered oil field at the mean was calculated at about 2.7 BBO. Associated gas in undiscovered oil fields ranges from about 6.6 TCF (F95) to 27.0 TCF (F5), with a mean volume of associated gas of 16.1 TCF (table 3 ).

Mean volume of undiscovered oil in oil fields for the Horst-Block Anticlinal Oil AU is about 26.7 BBO (table 3). In terms of grown oil volume, about 88 percent of the oil has been discovered in this assessment unit. This percentage of discovered volume is somewhat skewed to the high end because about two-thirds of the total grown oil volume (grown discovered reserves plus undiscovered) is in Ghawar field.

In summary, this assessment predicts a good potential for numerous discoveries of moderate-size oil fields within the Horst-Block Anticlinal Oil AU in block-faulted structures to the south and west of Ghawar field. New-field discoveries within the assessment unit are predicted: (1) at the south end of the Greater Ghawar Uplift Province, (2) in the southeastern portion of the Interior Homocline-Central Arch Province, and (3) in a small area along the northwest flank of Rub 'al Khali Basin Province immediately south of Ghawar (fig. 30).

\section{Salt-Involved Structural Oil AU (20210202)}

A second assessment unit, the Salt-Involved Structural Oil AU, encompasses the north half of the Arabian SubBasin Tuwaiq/Hanifa-Arab TPS that is underlain by the
Infracambrian Hormuz Salt (fig. 3). The geologic model for this assessment unit thus describes an area in which halokinetic structures are the primary traps for hydrocarbons; most structures are salt domes, salt diapirs, and salt-assisted or salt-enhanced horst-block anticlines. Characteristics of the discovered and undiscovered fields of the Salt-Involved Structural Oil AU are shown in the input data form of Appendix 4; assessment results are summarized in table 3. A summary of historical exploration and production data of known and grown volumes for fields of the Salt-Involved Structural Oil AU is given in table 5 and plotted in figure 45 and figure 46.

Through 1995, the Petroconsultants (1996a) database suggests that, since the first discovery in 1938 through the last discovery in 1978, 12 oil fields and no gas fields of minimum size constitute the total known discoveries within the assessment unit (table 5). Cumulative known oil volume and gas volume from the 12 oil fields are about $43.8 \mathrm{BBO}$ and 45.7 TCF, respectively. Equivalent cumulative grown volume for the assessment unit is estimated at about $56.1 \mathrm{BBO}$ and 57.4 TCF of gas (table 5). The largest discovered oil field in the assessment unit, Berri field, has an estimated known volume of about 12-13 BBO and a grown volume of about 15-16 BBO (fig. 45). The range in size based on known volume for the 12 oil fields is between about $200 \mathrm{MMBO}$ and $13 \mathrm{BBO}$ (fig. 45); the median grown field size of all discovered fields is about 2.0 BBO (table 5).

The historical exploration and production data for new field wildcat wells in this assessment unit show that of the 47 new-field wildcats reported in the Petroconsultants (1996a) database, 36 were drilled between 1963 and 1994 (fig. 46), during which 7 of the 12 oil fields greater than the minimum size were discovered (fig. 45). The new-field wildcat data in figure 46 suggest that the latest surge of exploration was between 1987 and 1994, during which time no new Jurassic oil field of minimum size (fig. 45) was discovered in the SaltInvolved Structural Oil AU.

From historical production data, we calculate a median grown size of oil fields in the assessment unit, in terms of discovery halves, as follows: first half (1938-1963, six fields) of 5,471 MMBO; and second half (1978, six fields), of 1,008 MMBO (table 5). The estimated median size for undiscovered oil fields is 150 MMBO for the Salt-Involved Structural Oil AU (Appendix 4).

A median of 50 undiscovered oil fields greater than minimum size was estimated in the assessment unit (Appendix 4). Although only 12 oil fields of minimum size have been discovered to the present time, these discovered fields are comparatively very large. At a minimum size of $20 \mathrm{MMBO}$, this assessment expects that several fields within the assessment unit will be discovered during the next 30 years. The minimum number of undiscovered fields predicted is 10 ; the maximum number of undiscovered fields is estimated at 100 . The maximum field size for undiscovered oil fields was estimated at 6 billion barrels (Appendix 4).

The Monte Carlo simulation provided the following assessment results for the Salt-Involved Structural Oil AU 

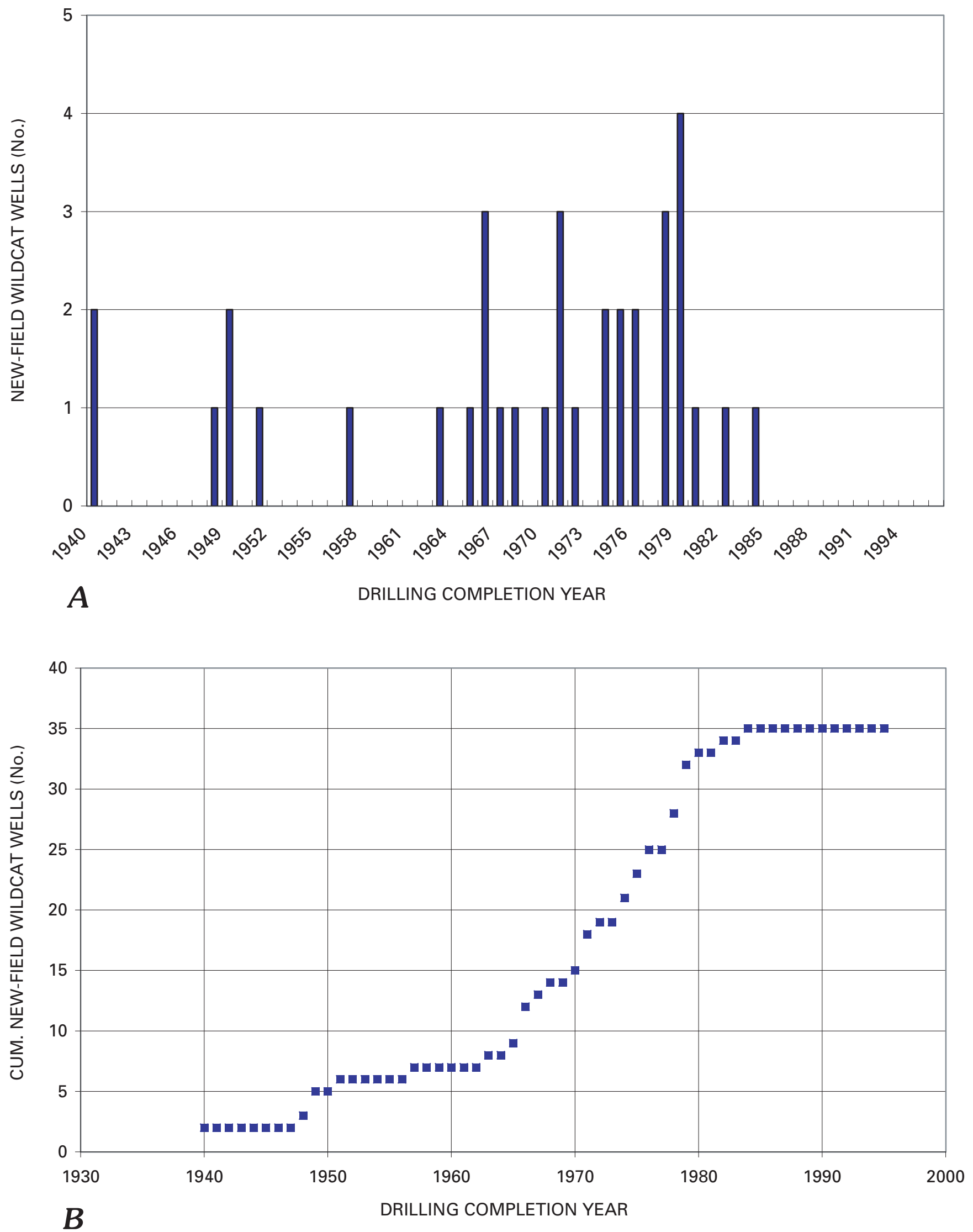

Figure 44. Plots of $A$, number (No.) of new-field wildcat wells versus drilling completion year, and $B$, cumulative (CUM.) number of new-field wildcat wells versus drilling completion year for Horst-Block Anticlinal Assessment Unit (20210201). Data derived and modified from Petroconsultants (1996a, b). 
Table 4. Known and grown discovered volumes of petroleum resources and discovery-history sequence for Horst-Block Anticlinal 0il Assessment Unit (20210201).

[MMBO, million barrels of oil. BCFG, billion cubic feet of gas. MMBNGL, million barrels of natural gas liquids. Fields containing less than 1 MMBO in oil fields or 6 BCFG in gas fields were not considered in the assessment. Fields were classified as oil or gas by the USGS. Fields without reported discovery dates were not included. NA means not applicable and is shown for volumes where only one field is present. Calculated values may not be equal to the sums of the component values because numbers have been independently rounded]

\section{Known and Grown Discovered Volumes}

\begin{tabular}{|c|c|c|c|c|c|c|c|c|}
\hline \multirow[b]{2}{*}{ Field Type } & \multicolumn{4}{|c|}{ Known (Discovered) Volumes } & \multicolumn{4}{|c|}{ Grown (Discovered) Volumes } \\
\hline & $\begin{array}{l}\text { Number } \\
\text { of Fields }\end{array}$ & Oil (MMBO) & Gas (BCFG) & NGL (MMBNGL) & $\begin{array}{l}\text { Number } \\
\text { of Fields }\end{array}$ & Oil (MMBO) & Gas (BCFG) & NGL (MMBNGL) \\
\hline Oil Fields & 25 & 155,145 & 229,615 & 8,400 & 25 & 196,585 & 286,849 & 10,427 \\
\hline Gas Fields & 0 & 0 & 0 & 0 & 0 & 0 & 0 & 0 \\
\hline Fields $<1 \mathrm{MMBOE}$ & 0 & 0 & 0 & 0 & 0 & 0 & 0 & 0 \\
\hline All Fields & 25 & 155,145 & 229,615 & 8,400 & 25 & 196,585 & 286,849 & 10,427 \\
\hline
\end{tabular}

\section{Discovery-History Sequence}

\begin{tabular}{|l|l|c|c|c|c|}
\hline \multirow{2}{*}{$\begin{array}{l}\text { Field } \\
\text { Type }\end{array}$} & \multicolumn{4}{|c|}{ Discovery-History Sequence - Grown (Discovered) Volumes } \\
\cline { 2 - 5 } & & $\begin{array}{c}\text { Year } \\
\text { (End of Period) }\end{array}$ & $\begin{array}{c}\text { Number of } \\
\text { Fields }\end{array}$ & $\begin{array}{c}\text { Total } \\
\text { Volume }\end{array}$ & $\begin{array}{c}\text { Mean } \\
\text { Size }\end{array}$ \\
\hline
\end{tabular}

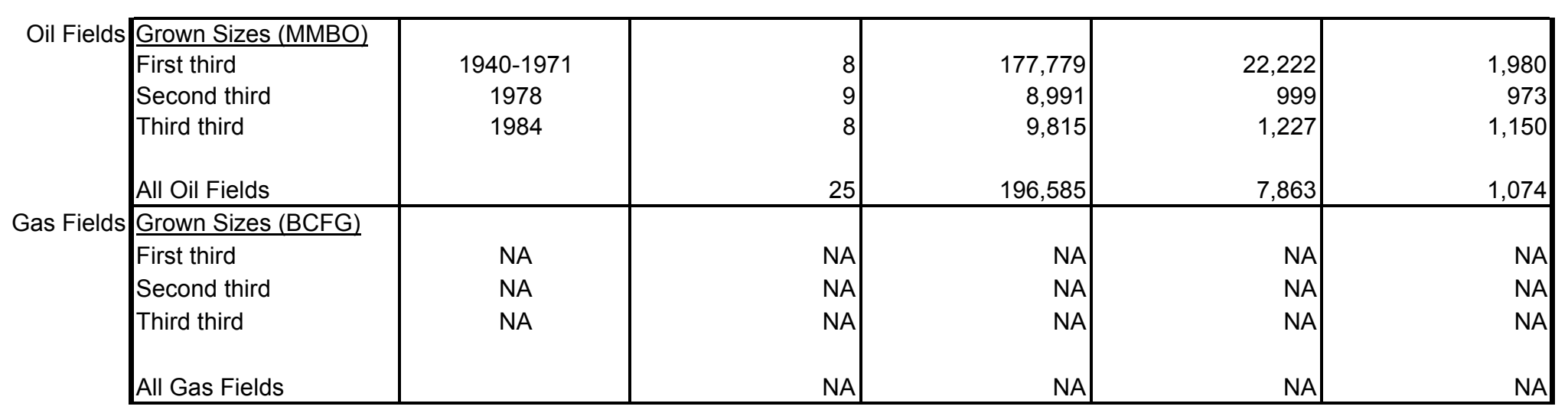



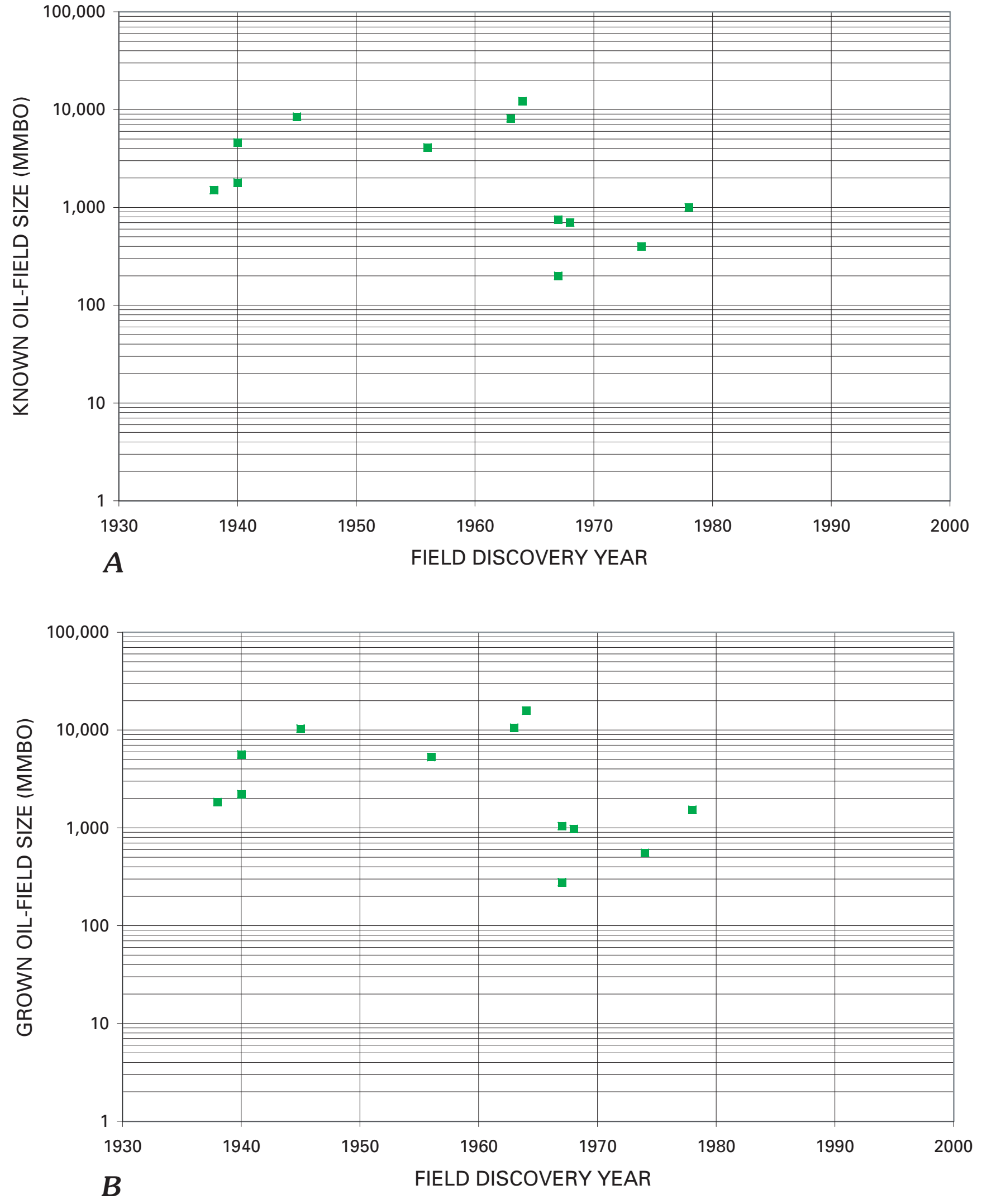

Figure 45. Plots of $A$, known oil-field size versus field discovery year, and $B$, grown oil-field size versus field discovery year for Salt-Involved Structural Oil Assessment Unit (20210202) of Arabian Sub-Basin Tuwaiq/Hanifa-Arab Total Petroleum System. Data derived and modified from Petroconsultants (1996a, b). MMB0, million barrels of oil. 
(table 3). Oil in undiscovered oil fields ranges from an F95 of about 5.7 BBO to an F5 of about 26.2 BBO, with a mean volume of undiscovered oil of about $15 \mathrm{BBO}$. The largest expected undiscovered oil field at the mean was calculated at about 2.2 BBO. Associated gas in undiscovered oil fields ranges from about 6.7 TCF (F95) to about 32.0 TCF (F5), with a mean volume of associated gas of about 18 TCF (table 3 ).

At the mean, about 79 percent (15 BBO undiscovered versus 56.1 BBO discovered) of the oil in oil fields has been discovered in the Salt-Involved Structural Oil AU. In summary, we predict good potential for large, new oil-field discoveries in salt-related structures in the northeast offshore Gulf portion of the Salt-Involved Structural Oil AU that are mostly within the borders of Iran.

\section{Summary}

The sequence stratigraphic, diagenetic, and tectonic histories of the Paleozoic and Jurassic sequence of the eastern Arabian Peninsula produced an exceptional combination of geologic elements and conditions favorable for petroleum formation, migration, and accumulation. These exceptional elements and conditions include (1) extensive geographic distribution of rich, mature source rocks, high-quality reservoir rocks, and highly efficient seal rocks and (2) the formation of large structural traps during or subsequent to peak oil and gas generation. These exceptional Paleozoic and Jurassic petroleum system elements combine to form one of the most prolific hydrocarbon-producing areas in the world.

The two total petroleum systems in central Arabia that are described here, the Central Arabia Qusaiba-Paleozoic TPS and the Jurassic Arabian Sub-Basin Tuwaiq/Hanifa-Arab TPS, are a more local part of the greater Paleozoic and Jurassic hydrocarbon systems of the eastern Arabian Peninsula. Both the Central Arabia Qusaiba-Paleozoic TPS and the Arabian Sub-Basin Tuwaiq/Hanifa-Arab TPS encompass the Greater Ghawar Uplift Province (USGS Province 2021) and portions of surrounding geologic provinces within Saudi Arabia, western Qatar, Bahrain, and the offshore northern Gulf portions of southern Iran along the Zagros Fold Belt.

Structures within these two total petroleum systems are unusually large, gentle anticlines and, mostly in the offshore, salt domes that were formed from reactivated basement fault blocks, halokinesis, or a combination of the two processes. Most of these structures were initially formed during the Hercynian tectonic event, during which the Arabian Plate underwent multiple phases of compression from the Late Devonian to the Early Carboniferous. Three post-Jurassic tectonic events are responsible for the formation and modification of structures and traps that consequently created oil and gas fields of such great magnitude: (1) Early Zagros rifting during the Early Triassic; (2) the First Alpine Orogeny during the Late Cretaceous; (3) the Second Alpine Orogeny in the middle to late Tertiary.
Hydrocarbons of the Central Arabia Qusaiba-Paleozoic TPS are sourced mainly by organic-rich hot shale that occurs in the basal part of the Lower Silurian Qusaiba Member of the Qalibah Formation. The Qusaiba source rock was thermally mature by the Late Jurassic in the deepest parts of the sedimentary basin in central Arabia; hydrocarbon expulsion began in the Early Cretaceous about 120 Ma. Oil and gas are produced from fluvial and eolian sandstones of the Permian Unayzah Formation and porous shallow marine sandstones of the Devonian Jauf Formation in the central and western parts of the Central Arabia Qusaiba-Paleozoic TPS. Oil and gas produced from the central Arabian fields and along the Central Arabian Arch were generated from the Silurian Qusaiba in an eastern, more mature part of the basin, and migrated westward and updip into the wrench-faulted structures. In the northern Gulf portion of the Central Arabia Qusaiba-Paleozoic TPS, basal transgressive marine sandstones and cyclic, dolomitic shelf carbonates of the Late Permian Khuff Formation produce gas and condensate; some sour gas and other non-hydrocarbon gases are also produced from these Khuff reservoirs.

The two assessment units (AU) recognized in the Central Arabia Qusaiba-Paleozoic TPS are related to structure type and presence of underlying Infracambrian salt: (1) an onshore Central Arch Horst-Block Anticlinal Oil and Gas AU, and (2) a mostly offshore, North Gulf Salt Basin Structural Gas AU. Mean volumes of undiscovered, conventional petroleum resources in the Central Arch Horst-Block Anticlinal Oil and Gas AU are estimated at about $19 \mathrm{BBO}$ in oil fields, more than 200 TCF of gas in gas fields, about 29 TCF of associated gas, and a total of nearly 18 BBNGL. Mean volume estimates for undiscovered gas and NGL in gas fields for the offshore North Gulf Salt Basin Structural Gas AU are about 153 TCF and 7 BBNGL, respectively. The mean total volume of undiscovered, conventional petroleum resource for the Central Arabia Qusaiba-Paleozoic TPS is estimated at about 108 BBOE.

Oil of the Arabian Sub-Basin Tuwaiq/Hanifa-Arab TPS is sourced by organic-rich marine carbonates of the Jurassic Tuwaiq Mountain and Hanifa Formations that were deposited in one of three intraplatform basins during the Jurassic and form a superfamily of oils with distinctive geochemical characteristics. Oils were generated and expelled from these source rocks beginning in the Cretaceous. Production is from cyclic carbonate-rock reservoirs of the Arab Formation in several giant and supergiant fields and including Ghawar field, Saudi Arabia.

The two assessment units recognized for the Arabian Sub-Basin Tuwaiq/Hanifa-Arab TPS are similarly related to structural style and presence of underlying Infracambrian salt: (1) an onshore Horst-Block Anticlinal Oil AU, and (2) a mostly offshore, Salt-Involved Structural Oil AU. Mean undiscovered, conventional petroleum resources in the HorstBlock Anticlinal Oil AU are estimated at about $27 \mathrm{BBO}$ in oil fields, about 16 TCF of associated gas, and a total of 642 MMBNGL. The mean volume estimate for undiscovered oil in oil fields for the offshore Salt-Involved Structural Oil AU is about $15 \mathrm{BBO}$; mean undiscovered associated gas and NGL 

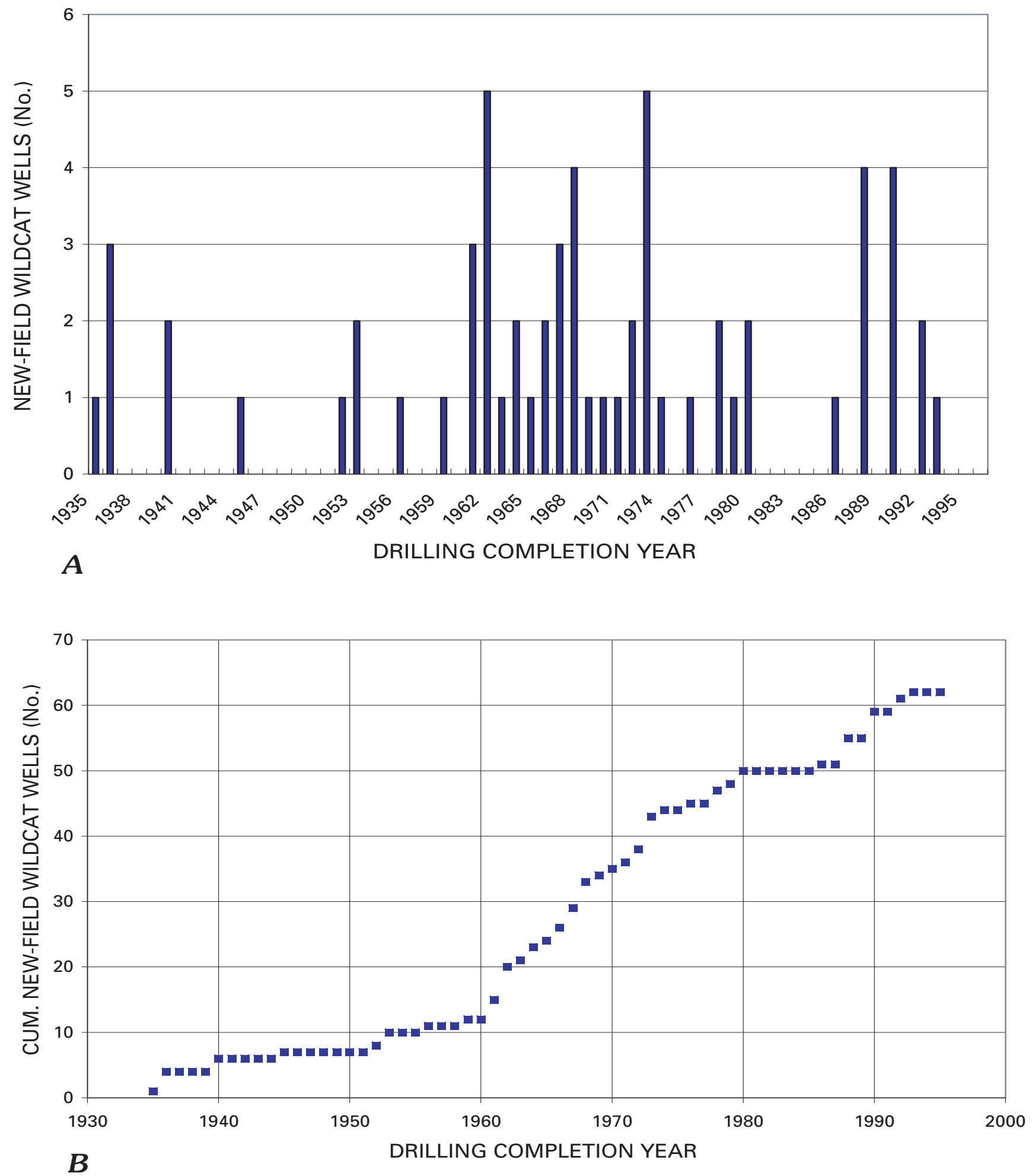

Figure 46. Plots of $A$, number (No.) of new-field wildcat wells versus drilling completion year, and $B$, cumulative (CUM.) number of new-field wildcat wells versus drilling completion year for Salt-Involved Structural Oil Assessment Unit (20210202), Arabian SubBasin Tuwaiq/Hanifa-Arab Total Petroleum System. Data derived and modified from Petroconsultants (1996a, b). 
Table 5. Known and grown discovered volumes and discovery-history sequence for Salt-Involved Structural Oil Assessment Unit (20210202).

[MMBO, million barrels of oil. BCFG, billion cubic feet of gas. MMBNGL, million barrels of natural gas liquids. Fields containing less than 1 MMBO in oil fields or 6 BCFG in gas fields were not considered in the assessment. Fields were classified as oil or gas by the USGS. Fields without reported discovery dates were not included. NA means not applicable and is shown for volumes where only one field is present. Calculated values may not be equal to the sums of the component values because numbers have been independently rounded]

\section{Known and Grown Discovered Volumes}

\begin{tabular}{|c|c|c|c|c|c|}
\hline \multirow[b]{2}{*}{ Field Type } & \multirow{2}{*}{\multicolumn{3}{|c|}{ Known (Discovered) Volumes }} & \multicolumn{2}{|c|}{ Grown (Discovered) Volumes } \\
\hline & & & & $\begin{array}{l}\text { Number } \\
\text { of Fields }\end{array}$ & Oil (MMBO) \\
\hline
\end{tabular}

\begin{tabular}{rr|r|r|r|r|r|r|r|} 
Oil Fields & 12 & 43,850 & 45,680 & 805 & 12 & 56,061 & 57,419 & 0 \\
Gas Fields & 0 & 0 & 0 & 0 & 0 & 1,042 \\
Fields <1 MMBOE & 0 & 0 & 0 & 0 & 0 & 0 \\
All Fields & 12 & 43,850 & 45,680 & 805 & 12 & 56,061 & 57,419 \\
\hline
\end{tabular}

\section{Discovery-History Sequence}

\begin{tabular}{|c|c|c|c|c|c|c|}
\hline \multirow{2}{*}{$\begin{array}{l}\text { Field } \\
\text { Type }\end{array}$} & & \multicolumn{5}{|c|}{ Discovery-History Sequence - Grown (Discovered) Volumes } \\
\hline & & $\begin{array}{c}\text { Year } \\
\text { (End of Period) } \\
\end{array}$ & $\begin{array}{l}\text { Number of } \\
\text { Fields }\end{array}$ & $\begin{array}{l}\text { Total } \\
\text { Volume }\end{array}$ & $\begin{array}{c}\text { Mean } \\
\text { Size }\end{array}$ & $\begin{array}{l}\text { Median } \\
\text { Size } \\
\end{array}$ \\
\hline \multirow[t]{4}{*}{ Oil Fields } & Grown Sizes (MMBO) & & & & & \\
\hline & First half & 1938-1963 & 6 & 35,886 & 5,981 & 5,471 \\
\hline & Second half & 1978 & 6 & 20,175 & 3,363 & 1,008 \\
\hline & All Oil Fields & & 12 & 56,061 & 4,672 & 2,021 \\
\hline \multirow[t]{5}{*}{ Gas Fields } & Grown Sizes (BCFG) & & & & & \\
\hline & First third & NA & $\mathrm{NA}$ & NA & $N A$ & NA \\
\hline & Second third & NA & NA & NA & $N A$ & NA \\
\hline & Third third & NA & NA & NA & NA & NA \\
\hline & All Gas Fields & & NA & NA & $\mathrm{NA}$ & NA \\
\hline
\end{tabular}


volumes in the assessment unit are estimated at about $18 \mathrm{TCF}$ and 719 MMBNGL, respectively. The mean total volume of undiscovered, unconventional petroleum resource for the Arabian Sub-Basin Tuwaiq/Hanifa-Arab TPS is about 49 BBOE.

In summary, the U.S. Geological Survey World Energy Assessment Team (2000) estimates that the Paleozoic and Jurassic total petroleum systems of central Arabia contain a combined mean undiscovered, conventional petroleum resource exceeding $60 \mathrm{BBO}, 417$ TCF of gas, and about 26 BBNGL. Combined analysis of both known oil and gas reserve volumes with potential undiscovered oil and gas volumes of the central Arabian Peninsula implies that this historically prolific hydrocarbon-producing area will continue to contribute a major supply of petroleum to the world market during the next 30 years.

\section{Selected References}

Abu-Ali, M.A., Franz, U.A., Shen, J., Monnier, F., Mahmoud, M.D., and Chambers, T.M., 1991, Hydrocarbon generation and migration in the Paleozoic Sequence of Saudi Arabia: Society of Petroleum Engineers (SPE) Middle East Oil Show, Manama, Bahrain: p. 345-356.

Abu-Ali, M.A., Rudkiewicz, J.L.L., McGillivray, J.G., and Behar, F., 1999, Paleozoic petroleum system of Central Saudi Arabia: GeoArabia, v. 4, p. 321-336.

Abu-Ali, M.A., Rudkiewicz, J.L.L., McGillivray, J.G., and Behar, F., 2001, Oil/gas migration system of Central Saudi Arabia: Saudi Aramco Journal of Technology, Spring 2001 issue, p. 10-25.

Ahlbrandt, T.S., Pollastro, R.M., Klett, T.R., Schenk, C.J., Lindquist, S., and Fox, J.E., 2000, Region 2 Assessment Summary-Middle East and North Africa, in U.S. Geological Survey World Energy Assessment Team, U.S. Geological Survey World Petroleum Assessment 2000-Description and results: U.S. Geological Survey Digital Data Series 60, four CD-ROM set.

Aktas, G., and Cocker, J.D., 1995, Diagenetic and depositional controls on reservoir quality in Khuff and Unayzah sandstones, Hawtah trend, central Saudi Arabia, in Al-Husseini, M.I., ed., Geo-94, Middle East Petroleum Geosciences Conference: Gulf Petrolink, Manama, Bahrain, v. 1, p. 44-52.

Al-Husseini, M.I., 1997, Jurassic sequence stratigraphy of the Western and Southern Arabian Gulf: GeoArabia, v. 2, p. 361-382.

Al-Husseini, M.I., 1998, Exploration and production features, Saudi Arabia: GeoArabia, v. 3, p. 322.
Al-Husseini, M.I., 2000, Origin of the Arabian plate structures-Amar Collision and Najd Rift: GeoArabia, v. 5, p. $527-542$.

Al-Husseini, M.I., and Chimblo, R.D., 1995, 3-D seismology in the Arabian Gulf Region, in Al-Husseini, M.I., ed., Geo94, Middle East Petroleum Geosciences Conference: Gulf Petrolink, Manama, Bahrain, v. 1, p. 93-102.

Alhajji, A.F., 2000, International outlook, Middle East-Disciplined output pays off: World Oil Magazine (Online magazine article, Special focus, WorldOil.com), v. 221, no. 8 (August), 2 p.

Al-Jallal, A.I., 1989, Depositional environments, diagenesis, and reservoir characteristics of the Permian Khuff Formation in Eastern Saudi Arabia: London, University of London Imperial College $\mathrm{Ph}$. D. thesis, $536 \mathrm{p}$.

Al-Jallal, A.I., 1995, The Khuff Formation-Its reservoir potential in Saudi Arabia and other Gulf countries, in AlHusseini, M.I., ed., Geo-94, Middle East Petroleum Geosciences Conference: Gulf Petrolink, Manama, Bahrain, v. 1, p. 103-119.

Al-Kadhi, H. and Hancock, J., 1980, Structure of the DurmeNisah segment of the central Arabian graben system: Jeddah, Saudi Arabia, Directorate General of Ministry of Resources, Mineral Resources Bulletin 16, 40 p.

Al-Khatieb, S.O., and Norman, J.W., 1982, A possibly extensive crustal failure system of economic interest: Journal of Petroleum Geology, v. 4, p. 319-327.

Al-Laboun, A.A., 1987, Unayzah Formation-A new Permian-Carboniferous unit in Saudi Arabia: American Association of Petroleum Geologists Bulletin, v. 71, p. 29-38.

Al-Siddiqi, A., and Dawe, R.A., 1999, Qatar's oil and gas fields-A review: Journal of Petroleum Geology, v. 22, p. 417-436.

Alsharhan, A.S., and Kendall, C.G.St.C., 1986, Precambrian to Jurassic rocks of Arabian Gulf and adjacent areas-Their facies, depositional setting, and hydrocarbon habitat: American Association of Petroleum Geologists Bulletin, v. 70, p. 977--1002.

Alsharhan, A.S., and Magara, K., 1994, The Jurassic of the Arabian Gulf Basin-Facies, depositional setting and hydrocarbon habitat, in Embry, A.F., Beauchamp, B., and Closs, D.J., eds., Pangea, global environments and resources: Canadian Society of Petroleum Geologists Memoir 17, p. 397-412.

Alsharhan, A.S., and Nairn, A.E.M., 1986, A review of the Cretaceous formations in the Arabian Peninsula and Gulf_-Part I, Lower Cretaceous (Thamama Group) stratigraphy and paleogeography: Journal of Petroleum Geology, v. 9 , p. $365-392$. 
Alsharhan, A.S., and Nairn, A.E.M., 1988, A review of the Cretaceous formations in the Arabian Peninsula and Gulf-Part II, Mid-Cretaceous (Wasia Group) stratigraphy and paleogeography: Journal of Petroleum Geology, v. 11, p. 89-112.

Alsharhan, A.S., and Nairn, A.E.M., 1990, A review of the Cretaceous formations in the Arabian Peninsula and Gulf-Part III, Upper Cretaceous (Aruma Group) stratigraphy and palegeography: Journal of Petroleum Geology, v. 13, p. 247-266.

Alsharhan, A.S., and Nairn, A.E.M., 1997, Sedimentary basins and petroleum geology of the Middle East: Amsterdam, The Netherlands, Elsevier Science B.V., 942 p.

Alsharhan, A.S., and Whittle, G.L., 1995, Carbonate-evaporite sequences of the Late Jurassic, southern and southwestern Arabian Gulf: American Association of Petroleum Geologists Bulletin, v. 79, p. 1608-1630.

Aoudeh, S.M., and Al-Hajri, S.A., 1995, Regional distribution and chronostratigraphy of the Qusaiba Member of the Qalibah Formation in the Nafud Basin, Northeastern Saudi Arabia, in Al-Husseini, M.I., ed., Geo-94, Middle East Petroleum Geosciences Conference: Gulf Petrolink, Manama, Bahrain, v. 1, p. 143-154.

Aqrawi, A.A.M., 1998, Paleozoic stratigraphy and petroleum systems of the western and southwestern deserts of Iraq: GeoArabia, v. 3, p. 229-248.

Arabian American Oil Company, 1959, Ghawar oil field, Saudi Arabia: American Association of Petroleum Geologists Bulletin, v. 43, p. 434-454.

Ayres, M.G., Bilal, M., Jones, R.W., Slentz, L.W., Tartir, M., and Wilson, A.O., 1982, Hydrocarbon habitat in main producing areas, Saudi Arabia: American Association of Petroleum Geologists Bulletin, v. 66, p. 1-9.

Baskin, D.K., and Peters, K.E., 1992, Early generation characteristics of sulfur-rich Monterey kerogen: American Association of Petroleum Geologists Bulletin, v. 76, p. 1-13.

Beydoun, Z.R., 1991, Arabian plate hydrocarbon geology and potential-A plate tectonic approach: American Association of Petroleum Geologists Bulletin Studies in Geology 33, $77 \mathrm{p}$.

Bishop, R.S., 1995, Maturation history of the Lower Paleozoic of the Eastern Arabian Platform, in Al-Husseini, M.I., ed., Geo-94, Middle East Petroleum Geosciences Conference: Gulf Petrolink, Manama, Bahrain, v. 1, p.180-189.

Blood, M., 2000, New Lower Paleozoic exploration plays in southwest Oman [abs.]: GeoArabia, v. 5, p. 58.

Blood, M., 2001, Exploration for a frontier salt basin in southwestern Oman: GeoArabia, v. 6, p. 159-176.
Bouroullec, J., and Meyer, A., 1995, Sedimentologic and diagenetic model of the Arab Formation (Qatar)—Reservoir implications, in Al-Husseini, M.I., ed., Geo-94, Middle East Petroleum Geosciences Conference: Gulf Petrolink, Manama, Bahrain, v. 1, p. 236-246.

BP Amoco, 2000, BP Amoco statistical review of world energy, June 2000: London, BP Amoco, 43 p.

Brown, G.F., Schmidt, D.L., and Huffman, A.C., 1989, Geology of the Arabian Peninsula_-Shield area of Western Saudi Arabia: U.S. Geological Survey Professional Paper 560-A, 188 p.

Cantrell, D.L., and Hagerty, R.M., 1999, Microporosity in Arab carbonates, Saudi Arabia: GeoArabia, v. 4, p. 129 154.

Cantrell, D.L., Swart, P.K., Handford, R.C., Kendall, C.G., and Westphal, H., 2001, Geology and production significance of dolomite, Arab-D reservoir, Ghawar field, Saudi Arabia: GeoArabia, v. 6, p. 45-59.

Charpentier, R.R., and Klett, T.R., 2000, Monte Carlo simulation method, Chapter MC in U.S. Geological Survey World Energy Assessment Team, U.S Geological Survey World Petroleum Assessment 2000_-Description and results: U.S. Geological Survey Digital Data Series 60, Version 1.0, four CD-ROM set, disk one, $15 \mathrm{p}$.

Chaube, A.N., and Al-Samahiji, J., 1995, Jurassic and Cretaceous of Bahrain-Geology and petroleum habitat, in Al-Husseini, M.I., ed., Geo-94, Middle East Petroleum Geosciences Conference: Gulf Petrolink, Manama, Bahrain, v. 1, p. 295-305.

Christensen, R.M., Wilson, A.O., Kushnir, D.W., and Slentz, L.W., 1977, Saudi Arabian oil-Their source, generation, and migration: Chevron report to Saudi Aramco, 141 p.

Christian, Louis, 1997, Cretaceous subsurface geology of the Middle East Region: GeoArabia, v. 2, p. 209-256.

Cole, G.A., Abu-Ali, M.A., Aoudeh, S.M., Carrigan, M.J., Chen, H.H., Colling, E.L., Gwathney, W.J., Al-Hajii, A.A., Halpern, H.I., Jones, P.J., Al-Sharidi, S.H., and Tobey, M.H., 1994, Organic geochemistry of the Paleozoic petroleum system of Saudi Arabia: Energy and Fuels, v. 8, p. 1425-1442.

Cole, G.A., Carrigan, H.H., Colling, Halpern, H.I., AlKhadhrawi, M.R., and Jones, P.J., 1994, Organic geochemistry of the Jurassic petroleum system in Eastern Saudi Arabia, in Embry, A.F., Beauchamp, B., and Closs, D.J., eds., Pangea, global environments and resources: Canadian Society of Petroleum Geologists Memoir 17, p. 413-438. 
Connally, T.C., and Whiltse, E.W., 1995, Ordovician sandstones in Central Saudi Arabia, in Al-Husseini, M.I., ed., Geo-94, Middle East Petroleum Geosciences Conference: Gulf Petrolink, Manama, Bahrain, v. 1, p. 321-333.

Douglas, J.D., 1996, Geostatistical model for the Arab-D reservoir, North Ain Dar Pilot, Ghawar field, Saudi Arabia: GeoArabia, v. 1, p. 267-284.

Droste, H.H.J., 1990, Depositional cycles and source rock development in an epeiric intra-platform basin-The Hanifa Formation of the Arabian Peninsula: Sedimentary Geology, v. 69 , p. 281-296.

Dyer, R.A., and Al-Husseini, M.I., 1991, The western Rub 'al Khali Infracambrian graben system: Society of Petroleum Engineers Paper 21396.

Edgell, H.S., 1991, Proterozoic salt basins of the Persian Gulf area and their role in hydrocarbon generation: Precambrian Research, v. 54, p. 1-14.

Edgell, H.S., 1992, Basement tectonics of Saudi Arabia as related to oil field structures, in Rickard, M.H. and others, eds., Basement tectonics 9: Dordrecht, The Netherlands, Kluwer Academic Publishers, p. 169-193.

Edgell, H. S., 1996, Salt tectonism in the Persian Gulf basin, in Aslop, G.I., Blundell, D.J., and Davison, I., eds., Salt tectonics: Geological Society of London Special Publication 100, p. 129-151.

Energy Information Administration (EIA), 2000, Saudi Arabia energy oil information: Accessed June 2001 at URL www.eia.doe.gov/cabs/saudi2.html, 4 p.

Evans, D.S., Bahabri, B.H., and Al-Otaibi, A.M, 1997, Stratigraphic trap in the Permian Unayzah Formation, Central Saudi Arabia: GeoArabia, v. 2, p. 259-278.

Faqira, M.I. and Al-Hawuaj, A.Y., 1998, Infracambrian salt basin in the western Rub 'al Khali, Saudi Arabia [abs.]: GeoArabia, v. 3, p. 93.

Fourcade, E., Azema, J., Cecca, F., Dercourt, J., Vrielynck, B., Bellion, Y., Sandulescu, M., and Ricou, L.E., 1993, Late Tithonian palaeoenvironments (138-135 Ma) map 1: 20,000,000, in Dercourt, J., Ricou, L.E., and Vrielynck, B., eds., Atlas Tethys palaeoenvironmental maps: Rueil-Malmaison, France, Beicip-Franlap.

Fox., J.E., and Ahlbrandt, T.S., 2002, Petroleum geology and total petroleum systems of the Widyan Basin and Interior Platform of Saudi Arabia and Iraq: U.S. Geological Survey Bulletin 2202-E, 26 p.

Frei, H., 1984, Mesozoic source rocks and oil accumulation in Qatar: Proceedings of OAPEC seminar on source and habitat of petroleum in the Arab countries, Kuwait, p. 115-124.
Gorin, G.E., Racz, L.G., and Walter, M.R., 1982, Late Precambrian-Cambrian sediments of Huqf Group, Sultanate of Oman: American Association of Petroleum Geologists Bulletin, v. 66, p. 2609-2627.

Grabowski, C.G., Jr., and Norton, I.O., 1995, Tectonic controls on the stratigraphic architecture and hydrocarbon systems of the Arabian Plate, in Al-Husseini, M.I., ed., Geo-94, Middle East Petroleum Geosciences Conference: Gulf Petrolink, Manama, Bahrain, v. 1, p. 413-430.

Grover, G.A., Jr., 1993, Abqaiq Hanifa reservoir-Geologic attributes controlling hydrocarbon production and water injection: 9th SPE Middle East Oil Technical Conference and Exhibition, Bahrain, p. 113-118.

Gulf PetroLink, 1999, Exploration and production features Egypt, Eritrea, Iran, Oman, Saudi Arabia, Sudan, Yemen, and United Arab Emirates: GeoArabia, v. 4, p. 381-425.

Gulf PetroLink, 2000, Preliminary chronostratigraphic chart of the Gulf region: Gulf PetroLink, Manama, Bahrain, one chart.

Heine, C.J., in press, Peri-glacial dune sands of the Unayzah Formation, Saudi Arabia: Aberdeen, Australia, University of Aberdeen Ph. D. dissertation.

Hughes, G.H., 1996, A new bioevent stratigraphy of Late Jurassic Arab-D carbonates of Saudi Arabia: GeoArabia, v. 1, p. 417-434.

Hughes-Clark, M.W., 1988, Stratigraphy and rock-unit nomenclature in the oil-producing area of interior Oman: Journal of Petroleum Geology, v. 11, p. 5-69.

Husseini, M.I., 1991, Tectonic and depositional model of the Silurian-Devonian Arabian and adjoining plates: American Association of Petroleum Geologists Bulletin, v. 75, p. $108-120$.

Husseini, M.I., and Husseini, S.I., 1990, Origin of Infracambrian salt basins in the Middle East, in Brooks, J., ed., Classic petroleum provinces: Geological Society London Special Publication 50, p. 279-292.

Ibrahim, M.W., Khan, M.S., and Khatib, H., 1981, Structural evolution of Harmaliyah oil field, Eastern Saudi Arabia: American Association of Petroleum Geologists Bulletin, v. 65, p. 2403-2416.

Janahi, I.A., and Mirza, M.S., 1991, Improving the productivity of Khuff gas wells in Bahrain field: Middle East Oil Show, Bahrain, Society of Petroleum Engineers SPE Paper 21441, p. 874-884.

Jawad Ali, W.A., and Al-Husseini, M., 1996, Exploration and production highlights: GeoArabia, v. 1, p. 376-379. 
Jones, P.J., and Stump, T.E., 1999, Depositional and tectonic setting of the Lower Silurian hydrocarbon source rock facies, Central Saudi Arabia: American Association of Petroleum Geologists Bulletin, v. 83, p. 314-332.

Kent, P.E., 1970, The salt plugs of the Persian Gulf region: Leicester Literary and Philosophical Transactions, v. 64, p. 56-88.

King, W.A., 1995, Geology of the Ordovician clastic reservoirs of Abu Jifan/Farhah oilfields, Saudi Arabia, in Al-Husseini, M.I., ed., Geo-94, Middle East Petroleum Geosciences Conference: Gulf Petrolink, Manama, Bahrain, v. 2, p. 593-604.

Klett, T.R., Ahlbrandt, T.S., Schmoker, J.W., and Dolton, G.L., 1997, Ranking of the world's oil and gas provinces by known petroleum volumes: U.S. Geological Survey OpenFile Report 97-463, one CD-ROM.

Klett, T.R., Schmoker, J.W., and Ahlbrandt, T.S., 2000, Assessment hierarchy and initial province ranking, Chapter AR in U.S. Geological Survey World Energy Assessment Team, U.S. Geological Survey World Petroleum Assessment 2000_Description and results: U.S. Geological Survey Digital Data Series 60, four CD-ROM set, disk one, 29 p.

Koepnick, R.B., Lowell, E.W., Kompanick, G.S., Al-Shammery, M.J., and Al-Amoudi, M.O., 1995, Sequence stratal geometries and burial-related microporosity developmentControls on performance of the Hadriya reservoir (Upper Jurassic) Berri field, Saudi Arabia, in Al-Husseini, M.I., ed., Geo-94, Middle East Petroleum Geosciences Conference: Gulf Petrolink, Manama, Bahrain, v. 2, p. 615-623.

Kompanick, G.S., Heil, R.J., and Al-Shammari, Z.A., 1995, Geologic modeling of the Hadriya reservoir using sequence stratigraphy and facies templates, Berri field, Saudi Arabia, in Al-Husseini, M.I., ed., Geo-94, Middle East Petroleum Geosciences Conference: Gulf Petrolink, Manama, Bahrain, v. 2, p. 625-641.

Konert, G., Afifi, A.M., Al-Hajri, S.A., and Droste, H.J., 2001, Paleozoic stratigraphy and hydrocarbon habitat of the Arabian Plate: GeoArabia, v. 6, p. 407-442.

Langdon, G.S., and Malacek, S.J., 1987, Seismic stratigraphic study of two Oxfordian carbonate sequences, Eastern Saudi Arabia: American Association of Petroleum Geologists Bulletin, v. 71, p. 403-618.

Levell, B.K., Graakman, J.H., and Rutten, K.W., 1988, Oil-bearing sediments of Gondwana glaciation in Oman: American Association of Petroleum Geologists Bulletin, v. 72, p. 775-796.

Lewan, M.D., 1998, Sulphur-radical control on petroleum formation rates: Nature, v. 391, p. 164-166.
Looseveld, R.J.H., Bell, A., and Terken, J.M., 1996, The tectonic evolution of interior Oman: GeoArabia, v. 1, p. $28-51$.

Lore, G.L., Brooke, J.P., Cooke, D.W., Klazynski, R.J., Olson, D.L., and Ross, K.M., 1996, Summary of the 1995 assessment of conventionally recoverable hydrocarbon resources of the Gulf of Mexico and Atlantic Outer Continental Shelf: Minerals Management Service OCS Report MMS 96-0047, $67 \mathrm{p}$.

Magoon, L.B., and Dow, W.G., 1994, The petroleum system, in Magoon, L.B., and Dow, W.G., eds., The Petroleum system-From source to trap: American Association of Petroleum Geologists Memoir 60, p. 3-24.

Magoon, L.B., and Schmoker, J.W., 2000, The total petroleum system-The natural fluid network that constrains the assessment unit, Chapter PS in U.S. Geological Survey World Energy Assessment Team, U.S. Geological Survey World Petroleum Assessment 2000_Description and results: U.S. Geological Survey Digital Data Series 60, four CD-ROM set, disk one, $31 \mathrm{p}$.

Mahmoud, M.D., Vaslet, D., and Husseini, M.I., 1992, The Lower Silurian Qalibah Formation of Saudi Arabia-An important hydrocarbon source rock: American Association of Petroleum Geologists Bulletin, v. 76, p. 1491-1506.

Mattes, B.W., and Conway-Morris, S., 1990, Carbonate/ evaporite deposition in the Late Precambrian-Early Cambrian Ara Formation of Southern Oman, in Robertson, A.H.F., Searle, M.P., and Ries, A.C., eds., The geology and tectonics of the Oman region: Geological Society of London Special Publication 49, p. 617-636.

McClure, H.A., 1980, Early Paleozoic glaciation in Arabia: Geological Society of America Bulletin, v. 91, p. 707-712.

McGillivray, J.G., 1994, Late Carboniferous and Early Permian petroleum geology, Central Saudi Arabia, in Embry, A.F., Beauchamp, B., and Closs, D.J., eds., Pangea, global environments and resources: Canadian Society of Petroleum Geologists Memoir 17, p. 383-396.

McGillivray, J.G., and Husseini, M.I., 1992, The Paleozoic petroleum geology of Saudi Arabia: American Association of Petroleum Geologists Bulletin, v. 76, p. 1473-1490.

McGuire, M.D., Kowpnick, R.B., Markello, J.R., Stockton, M.L., Waite, L.E., Kompanick. G.S., Al-Shammery, M.J., and Al-Amoudi, M.O., 1993, Importance of sequence stratigraphic concepts in development of reservoir architecture in Upper Jurassic grainstones, Hadriya and Hanifa reservoirs, Saudi Arabia: 9th SPE Middle East Oil Technical Conference and Exhibition, Manama, Bahrain, p. 489-499. 
Mendeck, M.F., and Al-Madani, A.A., 1995, Bahrain fieldChallenges for reservoir characterization, in Al-Husseini, M.I., ed., Geo-94, Middle East Petroleum Geosciences Conference: Gulf Petrolink, Manama, Bahrain, v. 2, p. 669-677.

Meyer, F.O., and Price, R.C., 1993, A new Arab-D depositional model, Ghawar field, Saudi Arabia: 9th SPE Middle East Oil Technical Conference and Exhibition, Manama, Bahrain, p. 465-474.

Milner, P.A., 1998, Source rock distribution and thermal maturity in the Southern Arabian Peninsula: GeoArabia, v. 3, p. 339-356.

Molnar, P., and Tapponier, P., 1975, Cenozoic tectonics of Asia-Effects of a continental collision: Science, v. 189, p. 419-426.

Murris, R.J., 1980, Middle East-Stratigraphic evolution and oil habitat: American Association of Petroleum Geologists Bulletin, v. 64, p. 597-618.

Oterdoom, W.H., Worthington, M., and Partington, M., 1999, Petrological and tectonostratigraphic evidence for a MidOrdovician rift pulse on the Arabian Peninsula: GeoArabia, v. 4 , p. $467-500$.

Petroconsultants, 1996a, Petroleum exploration and production database: Houston, Texas, Petroconsultants, Inc. [database available from Petroconsultants, Inc., P.O. Box 740619, Houston, TX 77274-0619].

Petroconsultants, 1996b, PetroWorld 21: Houston, Texas, Petroconsultants, Inc. [database available from Petroconsultants, Inc., P.O. Box 740619, Houston, TX 77274-0619].

Polkowski, G.R., 1997, Degradation of reservoir quality by clay content, Unayzah Formation, Central Saudi Arabia: GeoArabia, v. 2, p. 49-64.

Pollastro, R.M., 1999, Ghaba Salt Basin Province and Fahud Salt Basin Province, Oman-Geological overview and total petroleum systems: U.S. Geological Survey Bulletin 2167, 45 p., Available only online at http://geology.cr.usgs.gov/ pub/bulletins/b2167/.

Pollastro, R.M., Karshbaum, A.S., and Viger, R.J., 1999, Map showing geology, oil and gas fields, and geologic provinces of the Arabian Peninsula: U.S. Geological Survey OpenFile Report 97-470B, Version 2, one CD-ROM.

Pollastro, R.M., Schenk, C.J., and Ahlbrandt, T.S., 2002, Undiscovered oil and gas resources of Lower Silurian Qusaiba-Paleozoic Total Petroleum Systems, Arabian Peninsula: U.S. Geological Survey Fact Sheet FS-008-02, 2 p.

Powers, R.W., 1968, Saudi Arabia (excluding Arabian Shield), Asie, in Lexique Stratigraphique International: Centre Nationale de la Recherche Scientifique, v. 3, 177 p.
Powers, R.W., Ramirez, L.F., Redmon, C.D., and Elberg, E.L., Jr., 1966, Geology of the Arabian Peninsula: U.S. Geological Survey Professional Paper 560-D, 127 p.

Purser, B.H., 1978, Early diagenesis and the preservation of porosity in Jurassic limestones: Journal of Petroleum Geology, v. 12, p. 83-94.

Saner, S., and Abdulghani, W.M., 1995, Lithostratigraphy and depositional environments of the Upper Jurassic Arab-C carbonate and associated evaporites in the Abqaiq field, Eastern Saudi Arabia: American Association of Petroleum Geologists Bulletin, v. 79, p. 394-409.

Saner, S., and Sahin, A., 1999, Lithological and zonal porosity-permeability distributions in the Arab-D reservoir, Uthmaniyah field, Saudi Arabia: American Association of Petroleum Geologists Bulletin, v. 83, p. 230-243.

Schenk, C.J., and Pollastro, R.M., 2000, Assessment of undiscovered oil and gas resources of the Greater Rub 'al Khali basin by application of the total petroleum system concept—Part II, The Qusaiba-Paleozoic petroleum system: GeoArabia, v. 5, p. 175.

Schmidt, D.L., Hadley, D.G., and Stoeser, D.B., 1979, Late Proterozoic crustal history of the Arabian Shield, Southern Najd Province, Kingdom of Saudi Arabia, in Evolution and mineralization of the Arabian-Nubian Shield: Jeddah, Saudi Arabia, Institute of Applied Geology v. 2, p. 41-58.

Schmoker, J.W., and Crovelli, R.A., 1998, A simplified spreadsheet program for estimating future growth of oil and gas reserves: Nonrenewable Resources, v. 7, no. 2, p. 149-155.

Schmoker, J.W., and Klett, T.R., 2000, U.S. Geological assessment model for undiscovered conventional oil, gas, and NGL resources-The Seventh Approximation, Chapter AM in U.S. Geological Survey World Energy Assessment Team, U.S. Geological Survey World Petroleum Assessment 2000-Description and results: USGS Digital Data Series DDS-60, disk one, Version 1.0, $18 \mathrm{p}$.

Senalp, M., and Al-Duaiji, A., 1995, Stratigraphy and sedimentation of the Unayzah reservoirs, Central Saudi Arabia, in Al-Husseini, M.I., ed., Geo-94, Middle East Petroleum Geosciences Conference: Gulf Petrolink, Manama, Bahrain, v. 1, p. 837-847.

Senalp, M., and Al-Duaiji, A., 2001, Qasim Formation-Ordovician storm- and tide-dominated shallow-marine siliclastic sequences, Central Saudi Arabia: GeoArabia, v. 6, p. 233-268.

Senalp, M., and Al-Laboun, A., 1996, Stratigraphy and age of the glacial deposits in Qasim region, Central Arabia, in AlHusseini, M.I., ed., Geo-94, Middle East Petroleum Geosciences Conference: Gulf Petrolink, Manama, Bahrain, v. 1, p. 192-193. 
Sharief, F.A.M., 1986, Depositional environments of the Triassic system of central Saudi Arabia: Geological Journal, v. 21, p. 402-420.

Sharland, P.R., Archer, R., Casey, D.M., Davies, R.B., Hall, S.H., Heward, A.P., Horbury, A.D., and Simmons, M.D., 2001, Arabian Plate sequence stratigraphy: GeoArabia Special Publication 2, Gulf Petrolink, Manama, Bahrain, 371 p.

Simms, S.C., 1995, Structural style of recently discovered oil fields, Central Saudi Arabia, in Al-Husseini, M.I., ed., Geo94, Middle East Petroleum Geosciences Conference: Gulf Petrolink, Manama, Bahrain, v. 1, p. 861-866.

Stern, R., 1994, The Najd Fault System, Saudi Arabia and Egypt-A late Precambrian rift-related transform system?: Tectonics, v. 4, p. 497-511.

Stump, T.E., and van der Eem, J.G., 1995, Overview of the stratigraphy, depositional environments, and periods of deformation of the Wajid outcrop belt, southwestern Saudi Arabia, in Al-Husseini, M.I., ed., Geo-94, Middle East Petroleum Geosciences Conference: Gulf Petrolink, Manama, Bahrain, v. 1, p. 867-876.

Sutcliffe, O.E., Harper, D.A.T., Ait Salem, A., Whittington, R.J., and Craig, J., 2000, The development of an atypical Hirnantia-brachiopod found and the onset of glaciation in the Late Ordovician, Gondwana: Transactions of the Royal Society of Edinburgh Earth Science, 90 p.

U.S. Geological Survey World Energy Assessment Team, 2000, U.S. Geological Survey World Petroleum Assessment 2000Description and results: U.S. Geological Survey Digital Data Series DDS-60, version 1.0, four CD-ROM set.
Vaslet, D., 1987, Early Paleozoic glacial deposits of Saudi Arabia; A lithostratigraphic revision: Saudi Arabian Directorate General for Mineral Resources, Technical Record BRGMTR-07-1, $24 \mathrm{p}$.

Webster, I., 2000, Basement structure and escape tectonics in the eastern Arabian Peninsula—Applications to early Paleozoic hydrocarbon prospectivity [abs.]: GeoArabia, v. 5, p. 199.

Weekly Petroleum Argus, 2000, Saudi Arabia Special ReportNew chapter for Saudi development: Weekly Petroleum Argus, v. 30 , no. 29 , p. $8-11$.

Weijermars, Ruud, 1998, Plio-Quaternary movement of the East Arabian Block: GeoArabia, v. 3, p. 509-540.

Wender, L.E., Bryant, J.W., Dickens, M.F., Neville, A.S., and Al-Moqbel, A.M., 1998, Paleozoic (Pre-Khuff) hydrocarbon geology of the Ghawar area, Eastern Saudi Arabia: GeoArabia, v. 3, p. 273-301.

Williams, P.L., Vaslet, D., Johnson, P.R., Berthiaux, A., LeStrat, P., and Fourniguet, J., 1986, Geologic map of the Jabal Habashi Quadrangle, Sheet 26F, Kingdom of Saudi Arabia: Saudi Arabian Deputy Ministry for Minerals Resources Geoscience Map GM-98A.

Yousif, S., and Nouman, G., 1997, Jurassic geology of Kuwait: GeoArabia, v. 2, p. 91-110.

Zeigler, M.A., 2001, Late Permian to Holocene paleofacies evolution of the Arabian Plate and its hydrocarbon occurrence: GeoArabia, v. 6, p. 445-504. 


\section{Appendix 1. Seventh Approximation Input Form for Central Arch Horst-Block Anticlinal Oil and Gas Assessment Unit (20210101), Central Arabia Qusaiba-Paleozoic Total Petroleum System}

Contained in this appendix are the detailed input characteristics, selected ancillary data, and country or other land parcel allocations of undiscovered resources for Central Arch Horst-Block Anticlinal Oil and Gas Assessment Unit (20210101). These data were used in the calculations of the undiscovered resources, and may be of use to those pursuing further analysis of the results. 


\author{
SEVENTH APPROXIMATION \\ NEW MILLENNIUM WORLD PETROLEUM ASSESSMENT \\ DATA FORM FOR CONVENTIONAL ASSESSMENT UNITS
}

Date:

$5 / 13 / 99$

Assessment Geologist:........

Region:........................

R.M. Pollastro

Province:

Middle East and North Africa

Greater Ghawar Uplift

Number: 2

Priority or Boutique..............

Total Petroleum System:......

Assessment Unit:.

Priority

Central Arabia Qusaiba Paleozoic

Number: 2021

* Notes from Assessor

Central Arch Horst-Block Anticlinal Oil and Gas

Number: 202101

Lower 48 growth factor. Assessment unit involves 6 priority provinces.

\title{
CHARACTERISTICS OF ASSESSMENT UNIT
}

Oil $(<20,000 \mathrm{cfg} / \mathrm{bo}$ overall) or $\mathrm{Gas}(\geq 20,000 \mathrm{cfg} / \mathrm{bo}$ overall $): .$. Oil

What is the minimum field size?......... $20 \quad$ mmboe grown ( $\geq 1 \mathrm{mmboe})$

(the smallest field that has potential to be added to reserves in the next 30 years)

Number of discovered fields exceeding minimum size: ...

Established ( $>13$ fields)

$\mathrm{X}$

Frontier (1-13 fields)

Oil: Hypothetical (no fields)

Gas:

4

Median size (grown) of discovered oil fields (mmboe):

Median size (grown) of discovered gas fields (bcfg):

1 st 3 rd

760

2nd 3rd

976

2nd 3rd 2033

3rd 3rd

539

1 st 3 rd

1691

3rd 3rd

Assessment-Unit Probabilities:

Attribute

Probability of occurrence (0-1.0)

1. CHARGE: Adequate petroleum charge for an undiscovered field $\geq$ minimum size................

2. ROCKS: Adequate reservoirs, traps, and seals for an undiscovered field $\quad \geq$ minimum size......

3. TIMING OF GEOLOGIC EVENTS: $\quad$ Favorable timing for an undiscovered field $\geq$ minimum size

\begin{tabular}{c}
1.0 \\
\hline 1.0 \\
\hline 1.0 \\
\hline
\end{tabular}

Assessment-Unit GEOLOGIC Probability

(Product of 1, 2, and 3):

1.0

4. ACCESSIBILITY: Adequate location to allow exploration for an undiscovered field

$\geq$ minimum size..

1.0

Number of Undiscovered Fields:

Oil fields:

Gas fields:

...............................min. no. $(>0)$ min. no. $(>0)$

$\begin{array}{ccc}15 & \text { median no. } & 90 \\ \text { median no. } & 120 \\ \end{array}$

$\max$ no.

max no.

$\frac{180}{220}$

Size of Undiscovered Fields:

What are the anticipated sizes ( grown ) of the above fields?: (variations in the sizes of undiscovered fields)

Oil in oil fields (mmbo) min. size

Gas in gas fields (bcfg):

\begin{tabular}{|c|c|c|}
\hline 20 & median size & 100 \\
\hline 120 & median size & 700 \\
\hline
\end{tabular}

max. size max. size 5000

50000 
Assessment Unit (name, no.)

Central Arch Horst-Block Anticlinal Oil and Gas, 20210101

AVERAGE RATIOS FOR UNDISCOVERED FIELDS, TO ASSESS COPRODUCTS

(uncertainty of fixed but unknown values)

Oil Fields: minimum

Gas/oil ratio (cfg/bo)

1000

$\mathrm{NGL} / \mathrm{gas}$ ratio (bngl/mmcfg)...

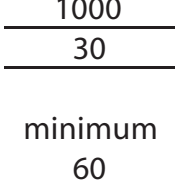

\begin{tabular}{c}
$\begin{array}{c}\text { median } \\
1500\end{array}$ \\
\hline 60 \\
\hline
\end{tabular}

maximum

2000

Gas fields:

Liquids/gas ratio (bngl/mmcfg).

60

median

90

Oil/gas ratio (bo/mmcfg).

$\longrightarrow \quad \overline{ }$

\section{SELECTED ANCILLARY DATA FOR UNDISCOVERED FIELDS}

(variations in the properties of undiscovered fields)

Oil Fields:

API gravity (degrees) $\ldots \ldots \ldots \ldots \ldots \ldots \ldots \ldots \ldots \ldots \ldots$

Sulfur content of oil (\%)..............................

Drilling Depth $(\mathrm{m})$

Depth (m) of water (if applicable).

Gas Fields :

Inert gas content (\%)...............................

$\mathrm{CO}_{2}$ content (\%).

Hydrogen-sulfide content (\%)....

Drilling Depth $(\mathrm{m})$....

Depth (m) of water (if applicable)

\begin{tabular}{c}
$\begin{array}{c}\text { minimum } \\
35\end{array}$ \\
\hline 0.02 \\
\hline 1000 \\
\hline
\end{tabular}

minimum

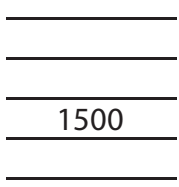

median

\begin{tabular}{c}
46 \\
\hline 0.07 \\
\hline 2000 \\
\hline
\end{tabular}

median

maximum
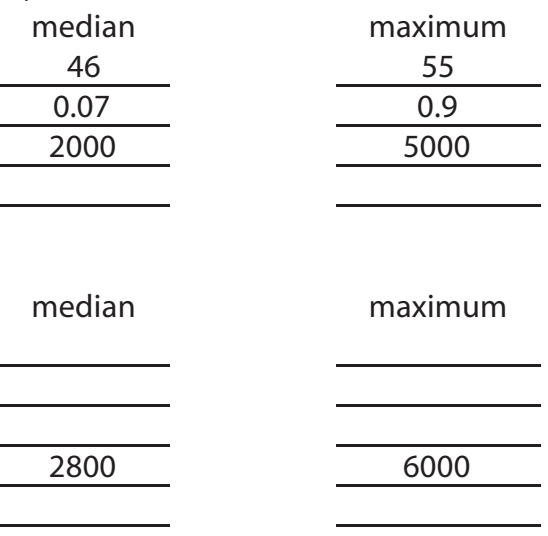

maximum

100 
Assessment Unit (name, no.)

Central Arch Horst-Block Anticlinal Oil and Gas, 20210101

\section{ALLOCATION OF UNDISCOVERED RESOURCES IN THE ASSESSMENT UNIT \\ TO COUNTRIES OR OTHER LAND PARCELS (uncertainty of fixed but unknown values)}

1. Saudi Arabia

represents 100 areal $\%$ of the total assessment unit

Oil in Oil Fields:

Richness factor (unitless multiplier):

Volume $\%$ in parcel (areal $\%$ x richness factor):...

Portion of volume $\%$ that is offshore $(0-100 \%) . . .$.

Gas in Gas Fields:

Richness factor (unitless multiplier):

Volume \% in parcel (areal \% x richness factor):

Portion of volume $\%$ that is offshore $(0-100 \%)$......

\begin{tabular}{lll} 
minimum & \multicolumn{1}{c}{ median } & \multicolumn{1}{c}{ maximum } \\
\hline & $\frac{100}{0}$ & \\
\hline minimum & $\frac{0}{\text { median }}$ & maximum \\
\hline & $\frac{100}{0}$ & \\
\hline
\end{tabular}

2. Province 2019

represents

5

areal \% of the total assessment unit

Oil in Oil Fields:

Richness factor (unitless multiplier):

Volume $\%$ in parcel (areal \% x richness factor):...

Portion of volume $\%$ that is offshore $(0-100 \%) . . .$.

Gas in Gas Fields:

Richness factor (unitless multiplier):....

Volume \% in parcel (areal \% x richness factor):

Portion of volume $\%$ that is offshore $(0-100 \%)$......

3. Province 2020

represents

Oil in Oil Fields:

Richness factor (unitless multiplier):

Volume $\%$ in parcel (areal \% x richness factor).

Portion of volume $\%$ that is offshore $(0-100 \%)$.....

Gas in Gas Fields:

Richness factor (unitless multiplier):....

Volume \% in parcel (areal \% x richness factor).

Portion of volume $\%$ that is offshore $(0-100 \%)$......

4. Province 2021

represents

Oil in Oil Fields:

Richness factor (unitless multiplier):

Volume \% in parcel (areal \% x richness factor).

Portion of volume $\%$ that is offshore $(0-100 \%)$......

Gas in Gas Fields:

Richness factor (unitless multiplier):

Volume $\%$ in parcel (areal $\% x$ richness factor)

Portion of volume $\%$ that is offshore (0-100\%)..... minimum

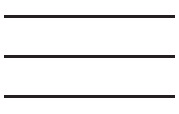

minimum

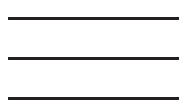

50

minimum

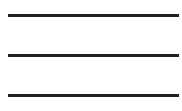

minimum

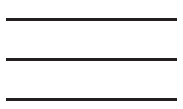

22 areal \% of the total assessment unit minimum

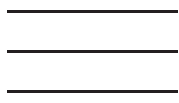

minimum areal $\%$ of the total assessment unit

\begin{tabular}{c}
\hline 2 \\
\hline 0 \\
median \\
\hline 5 \\
\hline 0 \\
\hline
\end{tabular}

maximum

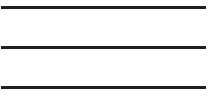

maximum

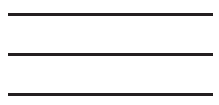

maximum

\begin{tabular}{c}
\hline 65 \\
\hline 0 \\
\hline
\end{tabular}

median

maximum

\begin{tabular}{c}
\hline 41 \\
\hline 0 \\
\hline
\end{tabular}

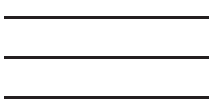

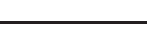

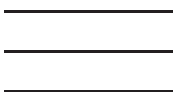

maximum

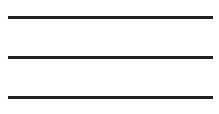

maximum 
5. Province 2022

represents

\section{Oil in Oil Fields:}

Richness factor (unitless multiplier):

Volume $\%$ in parcel (areal $\%$ x richness factor):...

Portion of volume $\%$ that is offshore $(0-100 \%) . . .$.

Gas in Gas Fields:

Richness factor (unitless multiplier):

Volume \% in parcel (areal \% x richness factor):..

Portion of volume $\%$ that is offshore $(0-100 \%) . . .$.

6. Province 2023

represents

Oil in Oil Fields:

Richness factor (unitless multiplier):

Volume \% in parcel (areal \% x richness factor):...

Portion of volume $\%$ that is offshore (0-100\%)......

Gas in Gas Fields:

Richness factor (unitless multiplier):....

Volume $\%$ in parcel (areal $\%$ x richness factor).

Portion of volume $\%$ that is offshore $(0-100 \%)$......

7. Province 2024

represents

Oil in Oil Fields:

Richness factor (unitless multiplier):.................

Volume \% in parcel (areal \% x richness factor):...

Portion of volume $\%$ that is offshore $(0-100 \%) . . .$.

Gas in Gas Fields:

Richness factor (unitless multiplier):....

Volume \% in parcel (areal \% x richness factor).

Portion of volume $\%$ that is offshore $(0-100 \%) . . .$. . areal $\%$ of the total assessment unit

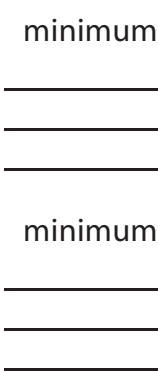

14

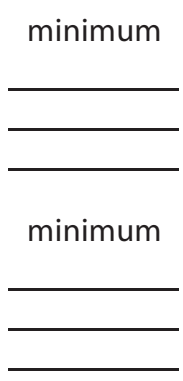

8

minimum

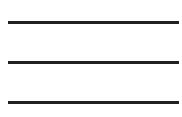

minimum areal \% of the total assessment unit

\begin{tabular}{c}
\hline 0 \\
\hline 0 \\
\hline
\end{tabular}

median

maximum

\begin{tabular}{c}
\hline 1 \\
\hline 0
\end{tabular}

maximum

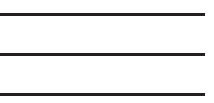

\begin{tabular}{c} 
median \\
\hline 20 \\
\hline 0 \\
median \\
\hline 20 \\
\hline 0 \\
\hline
\end{tabular}

maximum

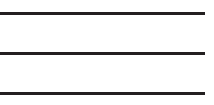

maximum

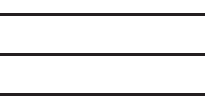

areal $\%$ of the total assessment unit

$+\frac{3}{3} \quad \frac{3}{0}$

maximum

$\begin{array}{r}\hline 3 \\ \hline 0 \\ \hline\end{array}$

$$
\text { median }
$$

maximum 


\section{Appendix 2. Seventh Approximation Input Form for North Gulf Structural Gas Assessment Unit (20210102), Central Arabia Qusaiba-Paleozoic Total Petroleum System}

Contained in this appendix are the detailed input characteristics, selected ancillary data, and country or other land parcel allocations of undiscovered resources for the North Gulf Structural Gas Assessment Unit (20210102). These data were used in the calculations of the undiscovered resources, and may be of use to those pursuing further analysis of the results. 


\section{SEVENTH APPROXIMATION \\ NEW MILLENNIUM WORLD PETROLEUM ASSESSMENT \\ DATA FORM FOR CONVENTIONAL ASSESSMENT UNITS}

\begin{tabular}{|c|c|c|c|}
\hline Date:............................ & $5 / 12 / 99$ & & \\
\hline Assessment Geologist:........ & R.M. Pollastro & \multirow{3}{*}{$\begin{array}{l}\text { Number: } \\
\text { Number: }\end{array}$} & \multirow[b]{2}{*}{2} \\
\hline Region:........................... & Middle East and North Africa & & \\
\hline Province:.......................... & Greater Ghawar Uplift & & 2021 \\
\hline Priority or Boutique............ & Priority & \multirow{4}{*}{$\begin{array}{l}\text { Number: } \\
\text { Number: } \\
\text { ovinces. }\end{array}$} & \\
\hline Total Petroleum System:...... & Central Arabia Qusaiba Paleozoic & & 202101 \\
\hline \multirow{3}{*}{$\begin{array}{l}\text { Assessment Unit:............. } \\
* \text { Notes from Assessor }\end{array}$} & North Gulf Salt Basin Structural Gas & & 20210102 \\
\hline & Lower 48 growth factor; assessment unit involves 3 priority pro & & \\
\hline & All fields discovered in 1966. & & \\
\hline
\end{tabular}

\section{CHARACTERISTICS OF ASSESSMENT UNIT}

Oil (<20,000 cfg/bo overall) or Gas ( $\geq 20,000 \mathrm{cfg} / \mathrm{bo}$ overall):... Gas

What is the minimum field size?......... $\quad 20 \quad$ mmboe grown ( $\geq 1 \mathrm{mmboe}$ )

(the smallest field that has potential to be added to reserves in the next 30 years)

Number of discovered fields exceeding minimum size:

Established ( $>13$ fields)

Frontier (1-13 fields)

$\mathrm{X}$

Oil: $\frac{0}{\text { Gas: }}$

2

Median size (grown) of discovered oil fields (mmboe):

Median size (grown) of discovered gas fields (bcfg)

1 st 3 rd

2nd 3rd

3rd 3rd

1st 3rd $\quad 17000 \quad$ 2nd 3rd

3rd 3rd

Assessment-Unit Probabilities:

Attribute

Probability of occurrence $(0-1.0)$

1. CHARGE: Adequate petroleum charge for an undiscovered field $\geq$ minimum size................

2. ROCKS: Adequate reservoirs, traps, and seals for an undiscovered field $\geq$ minimum size......

3. TIMING OF GEOLOGIC EVENTS: $\quad$ Favorable timing for an undiscovered field $\geq$ minimum size

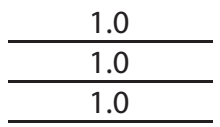

Assessment-Unit GEOLOGIC Probability $\quad$ (Product of 1, 2, and 3):

1.0

4. ACCESSIBILITY: Adequate location to allow exploration for an undiscovered field $\geq$ minimum size..

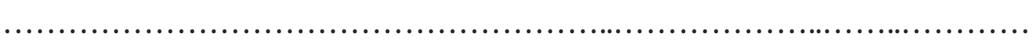

\section{UNDISCOVERED FIELDS}

Number of Undiscovered Fields: $\quad$ How many undiscovered fields exist that are $\quad \geq$ minimum size?: (uncertainty of fixed but unknown values)

Oil fields:

min. no. $(>0)$

Gas fields:

min. no. $(>0)$

median no.
median no.

$\max$ no.

Size of Undiscovered Fields: $\quad$ What are the anticipated sizes ( grown ) of the above fields?: (variations in the sizes of undiscovered fields)

Oil in oil fields (mmbo)

Gas in gas fields (bcfg): min. size

min. size

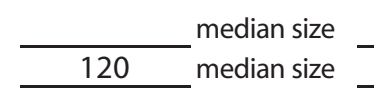

max. size max. size
60000 


\begin{tabular}{|c|c|c|c|}
\hline $\begin{array}{l}\text { Assessm } \\
\text { North G } \\
\end{array}$ & $\begin{array}{l}\text { Unit (name, } \\
\text { alt Basin Stru }\end{array}$ & 210102 & \\
\hline $\begin{array}{r}\text { AVERAGE RATIOS FOR UNDISCOVERE } \\
\text { (uncertainty of }\end{array}$ & $\begin{array}{l}\text { LDS, TO ASS } \\
\text { d but unkno }\end{array}$ & JCTS & \\
\hline Oil Fields: & minimum & median & maximum \\
\hline 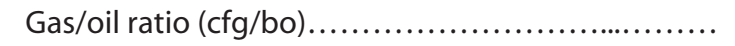 & & & \\
\hline NGL/gas ratio $($ bngl/mmcfg)........................ & & & \\
\hline Gas fields: & minimum & median & maximum \\
\hline Liquids/gas ratio (bngl/mmcfg)....................... & 22 & 44 & 66 \\
\hline $\begin{array}{l}\text { SELECTED ANCILLARY DATA } \\
\text { (variations in the pr }\end{array}$ & $\begin{array}{l}\text { R UNDISCOV } \\
\text { ties of undis }\end{array}$ & & \\
\hline Oil Fields: & minimum & median & maximum \\
\hline API gravity (degrees)................. & & & \\
\hline 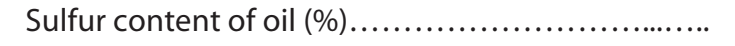 & & & \\
\hline 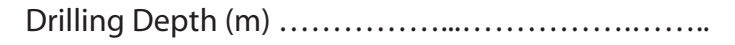 & & & \\
\hline Depth $(m)$ of water (if applicable).................... & & & \\
\hline Gas Fields : & minimum & median & maximum \\
\hline 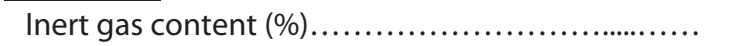 & & & \\
\hline 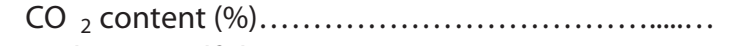 & & & \\
\hline Hydrogen-sulfide content $(\%) \ldots \ldots \ldots \ldots \ldots \ldots \ldots \ldots$ & & & \\
\hline 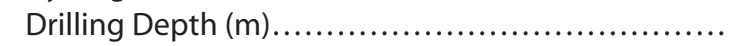 & 1500 & 3000 & 6000 \\
\hline Depth (m) of water (if applicable) .................. & 0 & 50 & 100 \\
\hline
\end{tabular}


Assessment Unit (name, no.)

North Gulf Salt Basin Structural Gas, 20210102

\section{ALLOCATION OF UNDISCOVERED RESOURCES IN THE ASSESSMENT UNIT TO COUNTRIES OR OTHER LAND PARCELS (uncertainty of fixed but unknown values)}

1. Iran

Oil in Oil Fields:

Richness factor (unitless multiplier):

Volume $\%$ in parcel (areal \% x richness factor):

Portion of volume $\%$ that is offshore $(0-100 \%) . . .$.

Gas in Gas Fields:

Richness factor (unitless multiplier):

Volume $\%$ in parcel (areal $\%$ x richness factor):...

Portion of volume $\%$ that is offshore $(0-100 \%) . . . .$.

2. Saudi Arabia

represents

Oil in Oil Fields:

Richness factor (unitless multiplier): ...

Volume \% in parcel (areal \% x richness factor).

Portion of volume $\%$ that is offshore $(0-100 \%) . . .$. .

Gas in Gas Fields:

Richness factor (unitless multiplier):....

Volume \% in parcel (areal \% x richness factor)

Portion of volume $\%$ that is offshore (0-100\%)......

3. Bahrain

represents

Oil in Oil Fields:

Richness factor (unitless multiplier):

Volume \% in parcel (areal \% x richness factor).

Portion of volume $\%$ that is offshore $(0-100 \%) . . . .$.

Gas in Gas Fields:

Richness factor (unitless multiplier):

Volume \% in parcel (areal \% x richness factor):

Portion of volume $\%$ that is offshore $(0-100 \%)$......

4. Qatar

represents

Oil in Oil Fields:

Richness factor (unitless multiplier):

Volume \% in parcel (areal \% x richness factor):...

Portion of volume $\%$ that is offshore (0-100\%).....

Gas in Gas Fields:

Richness factor (unitless multiplier):....

Volume $\%$ in parcel (areal $\%$ x richness factor):...

Portion of volume $\%$ that is offshore (0-100\%)......

\section{minimum}

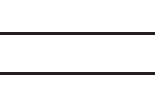

minimum

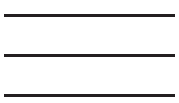

30

minimum

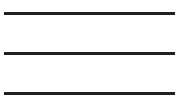

minimum

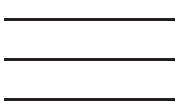

15

minimum

areal $\%$ of the total assessment unit

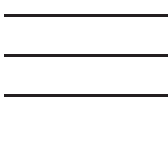

minimum

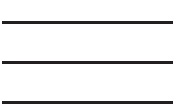

15

minimum

areal $\%$ of the total assessment unit

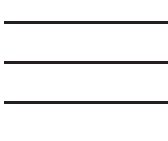

minimum

areal $\%$ of the total assessment unit

areal $\%$ of the total assessment unit

\begin{tabular}{c} 
median \\
\hline \\
\hline \\
\hline median \\
\hline 25 \\
\hline 90 \\
\hline
\end{tabular}

maximum

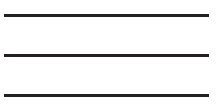

maximum

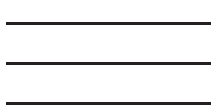

maximum

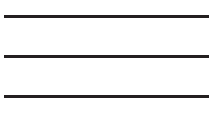

maximum

$\frac{10}{65}$

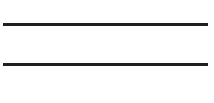

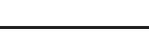

$$
\text { median }
$$

maximum

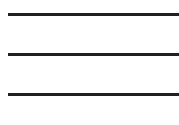

median

$\frac{20}{50}$

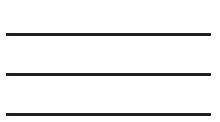

maximum 
5. Province 2021 represents

Oil in Oil Fields:

Richness factor (unitless multiplier):

Volume $\%$ in parcel (areal $\%$ x richness factor):...

Portion of volume $\%$ that is offshore $(0-100 \%) . . .$.

Gas in Gas Fields:

Richness factor (unitless multiplier):

Volume $\%$ in parcel (areal $\%$ x richness factor):...

Portion of volume $\%$ that is offshore $(0-100 \%) . . .$.

6. Province 2022 represents

Oil in Oil Fields:

Richness factor (unitless multiplier):

Volume\% in parcel (areal\% x richn

Portion of volume $\%$ that is offshore $(0$

Gas in Gas Fields:

Richness factor (unitless multiplier):

Volume $\%$ in parcel (areal $\% \mathrm{x}$ richness factor):...

Portion of volume $\%$ that is offshore $(0-100 \%) . . .$. .

7. Province 2024

represents

Oil in Oil Fields:

Richness factor (unitless multiplier):

Volume $\%$ in parcel (areal $\%$ x richness factor):...

Portion of volume $\%$ that is offshore $(0-100 \%) . . .$.

Gas in Gas Fields:

Richness factor (unitless multiplier):

Volume $\%$ in parcel (areal $\% \mathrm{x}$ richness factor):...

Portion of volume $\%$ that is offshore $(0-100 \%) . . . .$.
15

minimum

areal $\%$ of the total assessment unit

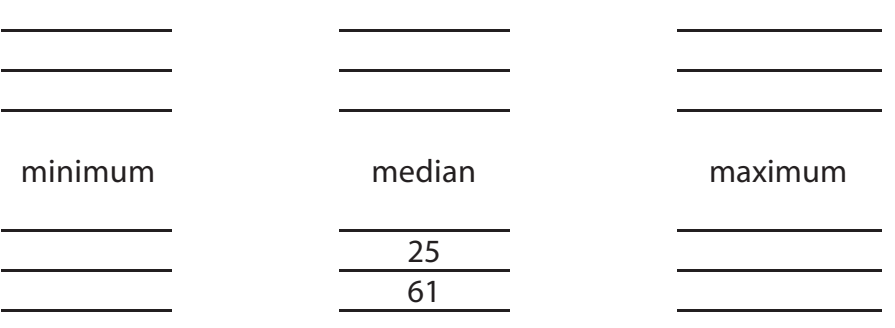

12 areal $\%$ of the total assessment unit

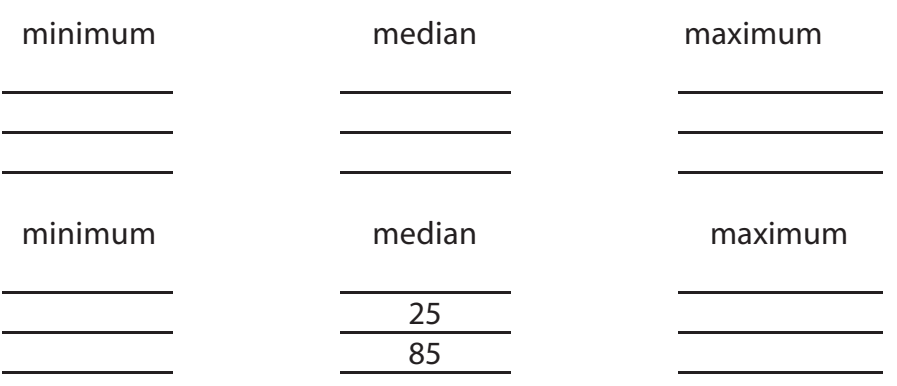

75 areal $\%$ of the total assessment unit

\begin{tabular}{cc} 
minimum & \multicolumn{1}{c}{ median } \\
\hline \multicolumn{1}{c}{} & \\
\hline minimum & median \\
\hline & $\frac{50}{95}$ \\
\hline
\end{tabular}

maximum

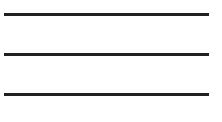

maximum 


\section{Appendix 3. Seventh Approximation Input Form for Horst-Block Anticlinal Oil Assessment Unit (20210201), Arabian Sub-Basin Tuwaiq/Hanifa-Arab Total Petroleum System}

Contained in this appendix are the detailed input characteristics, selected ancillary data, and country or other land parcel allocations of undiscovered resources for the Horst-Block Anticlinal Oil Assessment Unit (20210201). These data were used in the calculations of the undiscovered resources, and may be of use to those pursuing further analysis of the results. 


\section{SEVENTH APPROXIMATION}

NEW MILLENNIUM WORLD PETROLEUM ASSESSMENT

DATA FORM FOR CONVENTIONAL ASSESSMENT UNITS

Date:

5/14/99

Assessment Geologist:.........

Region:

R.M. Pollastro

Province:.....

Middle East and North Africa $N u m b e r: 2$

Priority or Boutique.

Greater Ghawar Uplift

Number: 2021

Total Petroleum System:......

Assessment Unit:

Priority

Arabian Sub-Basin Tuwaiq/Hanifa-Arab

Number: 202102

* Notes from Assessor

Horst-Block Anticlinal Oi

Number: 20210201

Lower 48 growth factor. Assessment unit involves 6 priority provinces.

\section{CHARACTERISTICS OF ASSESSMENT UNIT}

Oil $(<20,000 \mathrm{cfg} / \mathrm{bo}$ overall) or Gas ( $\geq 20,000 \mathrm{cfg} / \mathrm{bo}$ overall):... Oi

What is the minimum field size?......... $\quad 20 \quad$ mmboe grown ( $\geq 1 \mathrm{mmboe})$

(the smallest field that has potential to be added to reserves in the next 30 years)

Number of discovered fields exceeding minimum size:

Established ( $>13$ fields)

$\mathrm{X}$

Frontier (1-13 fields)

Oil

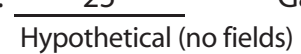

Gas: 0

Median size (grown) of discovered oil fields (mmboe):

Median size (grown) of discovered gas fields (bcfg):

1 st $3 r d$

1980

2nd 3rd

973

3rd 3rd

1150

1 st 3 rd

2nd 3rd

3rd 3rd

Assessment-Unit Probabilities:

Attribute

Probability of occurrence (0-1.0)

1. CHARGE: Adequate petroleum charge for an undiscovered field $\geq$ minimum size.

2. ROCKS: Adequate reservoirs, traps, and seals for an undiscovered field $>$ minimum size

3. TIMING OF GEOLOGIC EVENTS: $\quad$ Favorable timing for an undiscovered field $\geq$ minimum size

\begin{tabular}{c}
1.0 \\
\hline 1.0 \\
\hline 1.0 \\
\hline
\end{tabular}

Assessment-Unit GEOLOGIC Probability

(Product of 1, 2, and 3):

4. ACCESSIBILITY: Adequate location to allow exploration for an undiscovered field

$\geq$ minimum size...

1.0

Number of Undiscovered Fields:

Oil fields:

Gas fields:

Size of Undiscovered Fields:

Oil in oil fields (mmbo)

Gas in gas fields (bcfg):

\section{UNDISCOVERED FIELDS}

How many undiscovered fields exist that are $\geq$ minimum size?: (uncertainty of fixed but unknown values) min. no. $(>0)$ min. no. $(>0)$

$\begin{array}{cc}25 & \text { median no. } \\ \text { median no. } & \end{array}$

$\max$ no. $\max$ no. 215

What are the anticipated sizes ( grown ) of the above fields?: (variations in the sizes of undiscovered fields)

min. size

min. size

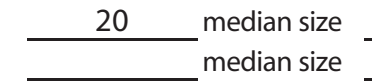

100 max. size max. size
6000 
Assessment Unit (name, no.)

Horst-Block Anticlinal Oil, 20210201

AVERAGE RATIOS FOR UNDISCOVERED FIELDS, TO ASSESS COPRODUCTS

(uncertainty of fixed but unknown values)

Oil Fields:

Gas/oil ratio (cfg/bo).

$\mathrm{NGL} / \mathrm{gas}$ ratio (bngl/mmcfg).

Gas fields:

Liquids/gas ratio (bngl/mmcfg).

Oil/gas ratio (bo/mmcfg).

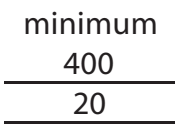

minimum

\begin{tabular}{c}
$\begin{array}{c}\text { median } \\
600\end{array}$ \\
\hline 40 \\
\hline
\end{tabular}

median

\begin{tabular}{c}
$\begin{array}{c}\text { maximum } \\
800\end{array}$ \\
\hline 60 \\
\hline
\end{tabular}

maximum

\section{SELECTED ANCILLARY DATA FOR UNDISCOVERED FIELDS} (variations in the properties of undiscovered fields)

Oil Fields:

API gravity (degrees)

Sulfur content of oil (\%)...............................

Drilling Depth $(\mathrm{m})$

Depth (m) of water (if applicable)

Gas Fields :

Inert gas content (\%)..............................

$\mathrm{CO}_{2}$ content (\%).

Hydrogen-sulfide content (\%).

Drilling Depth $(\mathrm{m})$....

Depth (m) of water (if applicable).

$$
\text { minimum }
$$

minimum

maximum

\begin{tabular}{c}
18 \\
\hline 0.5 \\
\hline 1000 \\
\hline
\end{tabular}

\begin{tabular}{c}
$\begin{array}{c}\text { maximum } \\
44\end{array}$ \\
\hline 4.6 \\
\hline 4000 \\
\hline
\end{tabular}

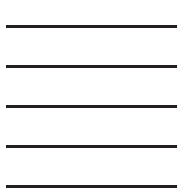

median

median

$\frac{31}{2}$

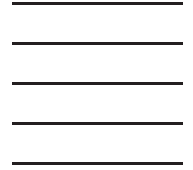


Assessment Unit (name, no.)

Horst-Block Anticlinal Oil, 20210201

\section{ALLOCATION OF UNDISCOVERED RESOURCES IN THE ASSESSMENT UNIT \\ TO COUNTRIES OR OTHER LAND PARCELS (uncertainty of fixed but unknown values)}

1. Saudi Arabia

represents

100

areal \% of the total assessment unit

Oil in Oil Fields:

Richness factor (unitless multiplier):

Volume $\%$ in parcel (areal $\%$ x richness factor):...

Portion of volume $\%$ that is offshore $(0-100 \%)$.....

Gas in Gas Fields:

Richness factor (unitless multiplier):

Volume \% in parcel (areal \% x richness factor).

Portion of volume $\%$ that is offshore $(0-100 \%) . . . .$.

2. Province 2019

represents

Oil in Oil Fields:

Richness factor (unitless multiplier):

Volume \% in parcel (areal \% x richness factor).

Portion of volume $\%$ that is offshore $(0-100 \%) . . .$. .

Gas in Gas Fields:

Richness factor (unitless multiplier):

Volume $\%$ in parcel (areal \% x richness factor)

Portion of volume $\%$ that is offshore (0-100\%)......

minimum

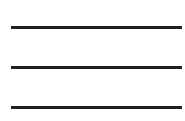

minimum

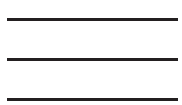

12

represents

Oil in Oil Fields:

Richness factor (unitless multiplier):

Volume \% in parcel (areal \% x richness factor).

Portion of volume $\%$ that is offshore $(0-100 \%)$......

Gas in Gas Fields:

Richness factor (unitless multiplier):

Volume \% in parcel (areal \% $x$ richness facto

Portion of volume $\%$ that is offshore $(0-100 \%) . . .$. .

\section{Province 2021}

represents

Oil in Oil Fields:

Richness factor (unitless multiplier):

Volume \% in parcel (areal \% x richness factor'

Portion of volume $\%$ that is offshore $(0-100 \%) . . .$.

Gas in Gas Fields:

Richness factor (unitless multiplier):

Volume \% in parcel (areal \% x richness factor):...

Portion of volume $\%$ that is offshore (0-100\%)......

\begin{tabular}{ll} 
minimum & \multicolumn{1}{c}{ median } \\
\hline & $\frac{100}{0}$ \\
\hline minimum & - \\
\hline
\end{tabular}

7

areal \% of the total assessment unit minimum

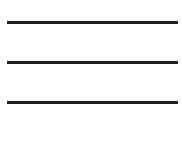

minimum

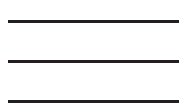

30 areal $\%$ of the total assessment unit

minimum

median

maximum

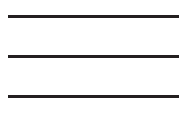

minimum

\begin{tabular}{c}
\hline 12 \\
\hline 0
\end{tabular}

median

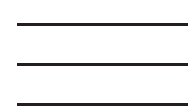

\begin{tabular}{c}
\hline 30 \\
\hline 0 \\
\hline
\end{tabular}

median

maximum

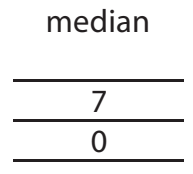

median

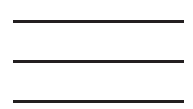

areal $\%$ of the total assessment unit

maximum

maximum

maximum maximum

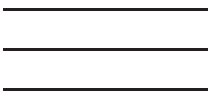

maximum
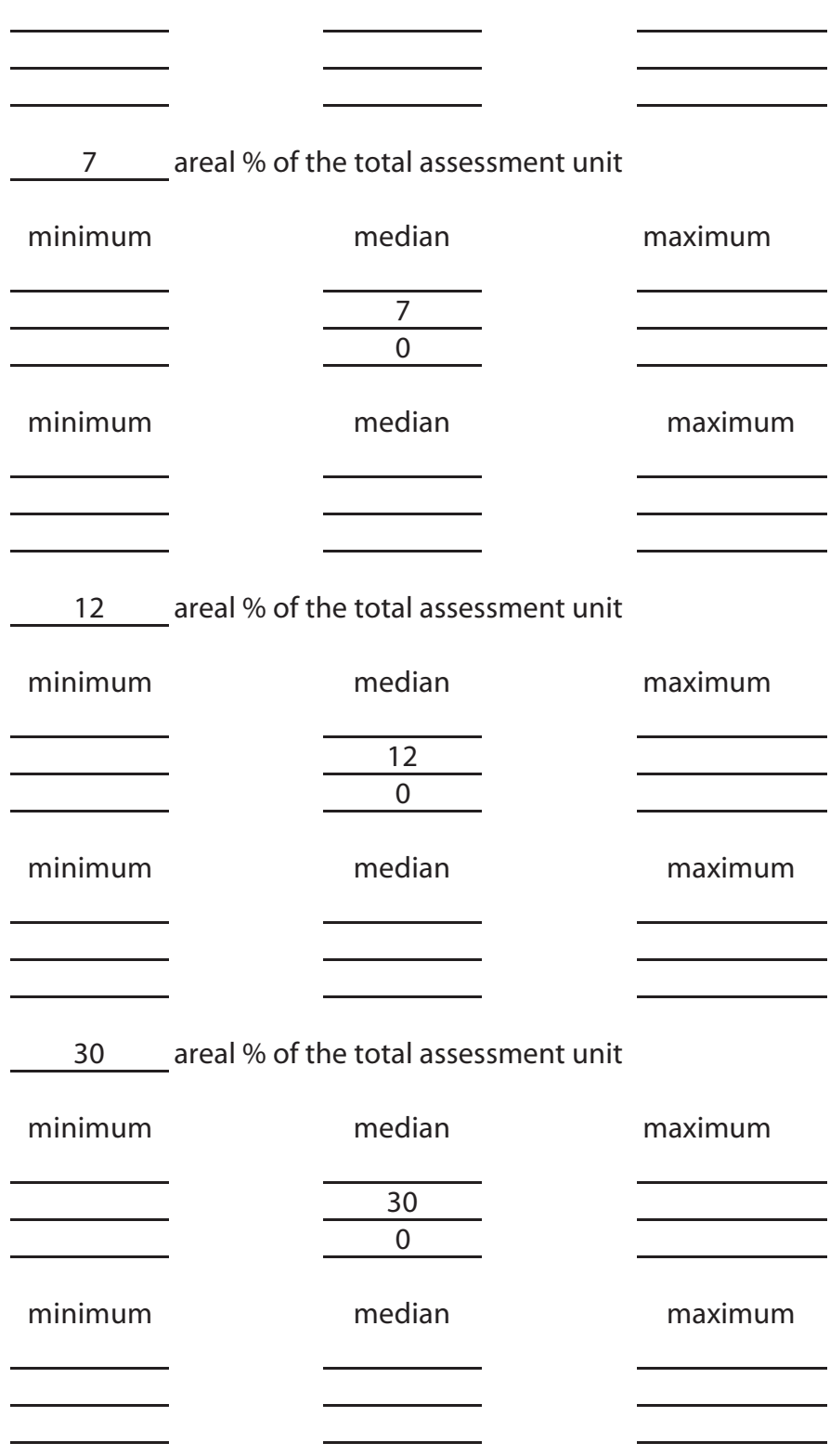
5. Province 2022

represents

Oil in Oil Fields:

Richness factor (unitless multiplier):

Volume \% in parcel (areal \% x richness factor):...

Portion of volume $\%$ that is offshore $(0-100 \%) . . .$.

Gas in Gas Fields:

Richness factor (unitless multiplier):

Volume \% in parcel (areal \% x richness factor):...

Portion of volume $\%$ that is offshore $(0-100 \%) . . .$. .

6. Province 2023

represents

Oil in Oil Fields:

Richness factor (unitless multiplier):

Volume \% in parcel (areal \% x richness factor):...

Portion of volume $\%$ that is offshore (0-100\%)......

Gas in Gas Fields:

Richness factor (unitless multiplier):....

Volume $\%$ in parcel (areal $\%$ x richness factor).

Portion of volume $\%$ that is offshore $(0-100 \%)$......

7. Province 2024

represents

Oil in Oil Fields:

Richness factor (unitless multiplier):.................

Volume $\%$ in parcel (areal \% x richness factor):...

Portion of volume $\%$ that is offshore $(0-100 \%) . . .$.

Gas in Gas Fields:

Richness factor (unitless multiplier):.

Volume \% in parcel (areal \% x richness factor).

Portion of volume $\%$ that is offshore $(0-100 \%)$...... areal $\%$ of the total assessment unit

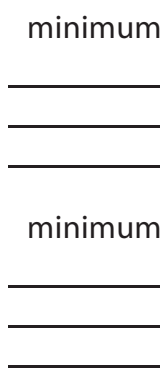

36

areal $\%$ of the total assessment unit

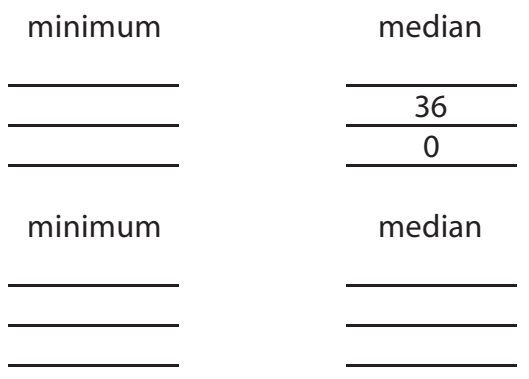

12 areal $\%$ of the total assessment unit minimum

minimum

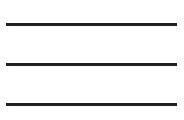

median

\begin{tabular}{c}
\hline 12 \\
\hline 0 \\
\hline
\end{tabular}

median maximum

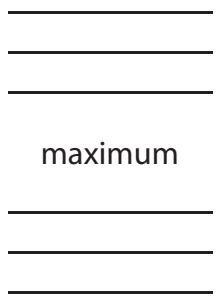

maximum

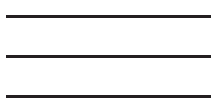

maximum

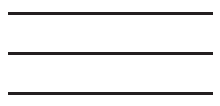

maximum

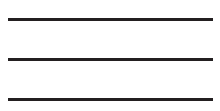

maximum 


\section{Appendix 4. Seventh Approximation Input Form for Salt-Involved Structural Oil Assessment Unit (20210202), Arabian Sub-Basin Tuwaiq/Hanifa-Arab Total Petroleum System}

Contained in this appendix are the detailed input characteristics, selected ancillary data, and country or other land parcel allocations of undiscovered resources for the Salt-Involved Structural Oil Assessment Unit (20210202). These data were used in the calculations of the undiscovered resources, and may be of use to those pursuing further analysis of the results. 
SEVENTH APPROXIMATION

NEW MILLENNIUM WORLD PETROLEUM ASSESSMENT

DATA FORM FOR CONVENTIONAL ASSESSMENT UNITS

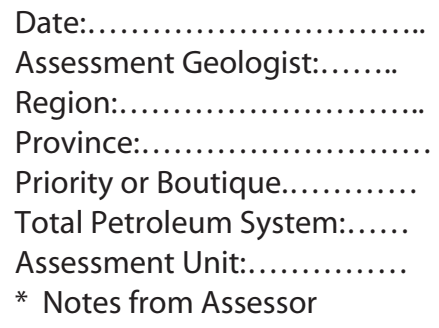

$5 / 14 / 99$

\begin{tabular}{|c|c|c|}
\hline R.M. Pollastro & \multirow{3}{*}{$\begin{array}{l}\text { Number: } \\
\text { Number: }\end{array}$} & \\
\hline Middle East and North Africa & & 2 \\
\hline Greater Ghawar Uplift & & 2021 \\
\hline Priority & & \\
\hline Arabian Sub-Basin Tuwaiq/Hanifa-Arab & Number: & 202102 \\
\hline Salt-Involved Structural Oil & Number: & 20210202 \\
\hline
\end{tabular}

CHARACTERISTICS OF ASSESSMENT UNIT

Oil $(<20,000 \mathrm{cfg} / \mathrm{bo}$ overall) $\quad$ or $\mathrm{Gas}(\geq 20,000 \mathrm{cfg} / \mathrm{bo}$ overall):... _ Oil

What is the minimum field size?........ $\quad 20 \quad$ mmboe grown ( $\geq 1 \mathrm{mmboe}$ )

(the smallest field that has potential to be added to reserves in the next 30 years)

Number of discovered fields exceeding minimum size: Established (>13 fields) Frontier (1-13 fields)

Oil: 12 Gas: Hypothetical (no fields)

Median size (grown) of discovered oil fields (mmboe):

Median size (grown) of discovered gas fields (bcfg): 1st 3rd $5471 \quad$ 2nd 3rd 1008 3rd 3rd 1 st 3 rd 2nd 3rd $3 r d 3 r d$

Assessment-Unit Probabilities: Attribute Probability of occurrence $(0-1.0)$

1. CHARGE: Adequate petroleum charge for an undiscovered field $\geq$ minimum size................

2. ROCKS: Adequate reservoirs, traps, and seals for an undiscovered field $\quad \geq$ minimum size......

3. TIMING OF GEOLOGIC EVENTS: $\quad$ Favorable timing for an undiscovered field $\geq$ minimum size

$\begin{array}{r}1.0 \\ \hline 1.0 \\ \hline 1.0 \\ \hline\end{array}$

Assessment-Unit GEOLOGIC Probability

(Product of 1, 2, and 3): 1.0

4. ACCESSIBILITY: Adequate location to allow exploration for an undiscovered field $\geq$ minimum size.......

\section{UNDISCOVERED FIELDS}

Number of Undiscovered Fields: $\quad$ How many undiscovered fields exist that are $\quad \geq$ minimum size?: (uncertainty of fixed but unknown values)

Oil fields:. $\min$. no. $(>0)$

Gas fields: min. no. $(>0)$

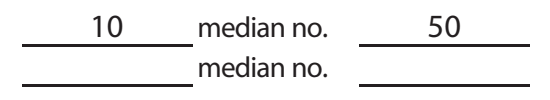

$\max$ no. $\max$ no.

Size of Undiscovered Fields:

What are the anticipated sizes ( grown ) of the above fields?: (variations in the sizes of undiscovered fields)

Oil in oil fields ( $\mathrm{mmbo}$ ). min. size Gas in gas fields (bcfg): min. size median size
median size 150 max. size max. size 
Assessment Unit (name, no.)

Salt-Involved Structural Oil, 20210202

\section{AVERAGE RATIOS FOR UNDISCOVERED FIELDS, TO ASSESS COPRODUCTS}

(uncertainty of fixed but unknown values)

Oil Fields:

Gas/oil ratio (cfg/bo).

$\mathrm{NGL} /$ gas ratio (bngl/mmcfg)

Gas fields:

Liquids/gas ratio (bngl/mmcfg)

Oil/gas ratio (bo/mmcfg).

\begin{tabular}{c}
$\begin{array}{c}\text { minimum } \\
900\end{array}$ \\
\hline 20 \\
minimum \\
\hline
\end{tabular}

\begin{tabular}{c}
$\begin{array}{c}\text { median } \\
1200\end{array}$ \\
\hline 40 \\
\hline
\end{tabular}

median

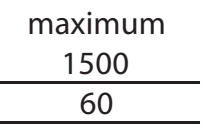

maximum

\section{SELECTED ANCILLARY DATA FOR UNDISCOVERED FIELDS}

(variations in the properties of undiscovered fields)

Oil Fields:

API gravity (degrees)......

Sulfur content of oil (\%)....

Drilling Depth $(\mathrm{m})$

Depth (m) of water (if applicable)

Gas Fields :

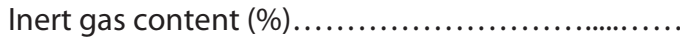

$\mathrm{CO}_{2}$ content (\%)

Hydrogen-sulfide content (\%)

Drilling Depth $(\mathrm{m})$.

Depth (m) of water (if applicable)....

\section{minimum}

\begin{tabular}{c}
14 \\
\hline 1.2 \\
\hline 1000 \\
\hline 0 \\
\hline
\end{tabular}

minimum median

\begin{tabular}{c}
30 \\
\hline 2.5 \\
\hline 2200 \\
\hline 50 \\
\hline
\end{tabular}

median

\begin{tabular}{c}
$\begin{array}{c}\text { maximum } \\
42\end{array}$ \\
\hline 6 \\
\hline 4000 \\
\hline 100 \\
\hline
\end{tabular}

maximum 
Assessment Unit (name, no.)

Salt-Involved Structural Oil, 20210202

\section{ALLOCATION OF UNDISCOVERED RESOURCES IN THE ASSESSMENT UNIT \\ TO COUNTRIES OR OTHER LAND PARCELS (uncertainty of fixed but unknown values)}

1. Iran represents 20 areal \% of the total assessment unit

Oil in Oil Fields:

Richness factor (unitless multiplier):

Volume \% in parcel (areal \% x richness fac

Portion of volume $\%$ that is offshore $(0-$

Gas in Gas Fields:

Richness factor (unitless multiplier):

Volume $\%$ in parcel (areal $\%$ x richness factor):...

Portion of volume $\%$ that is offshore $(0-100 \%) . . .$.

2. Saudi Arabia

represents

Oil in Oil Fields:

Richness factor (unitless multiplier):

Volume $\%$ in parcel (areal $\%$ x richness factor):...

Portion of volume $\%$ that is offshore $(0-100 \%) . . .$. .

Gas in Gas Fields:

Richness factor (unitless multiplier):

Volume $\%$ in parcel (areal \% x richness factor):...

Portion of volume $\%$ that is offshore (0-100\%).....

3. Bahrain

represents

Oil in Oil Fields:

Richness factor (unitless multiplier):

Volume $\%$ in parcel (areal $\%$ x richness factor):...

Portion of volume $\%$ that is offshore $(0-100 \%) . . .$.

Gas in Gas Fields:

Richness factor (unitless multiplier):

Volume \% in parcel (areal \% x richness factor).

Portion of volume $\%$ that is offshore $(0-100 \%)$......

4. Qatar

represents

Oil in Oil Fields:

Richness factor (unitless multiplier):

Volume \% in parcel (areal \% x richness factor):

Portion of volume $\%$ that is offshore $(0-100 \%) . . .$.

Gas in Gas Fields:

Richness factor (unitless multiplier):

Volume $\%$ in parcel (areal \% x richness factor).

Portion of volume $\%$ that is offshore $(0-100 \%) . . .$. .

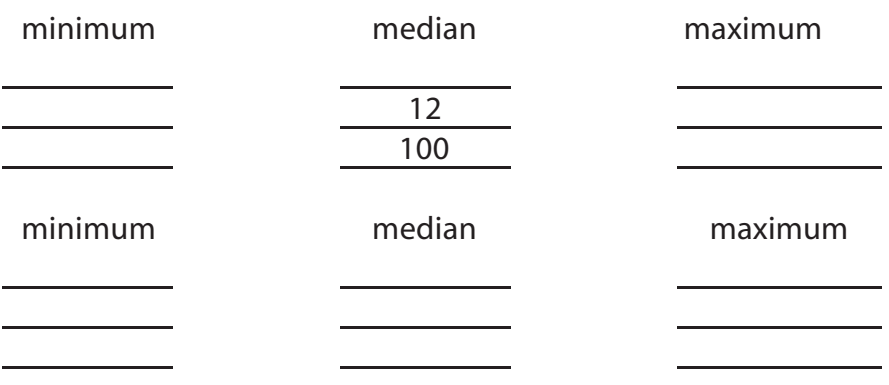

50 areal \% of the total assessment unit

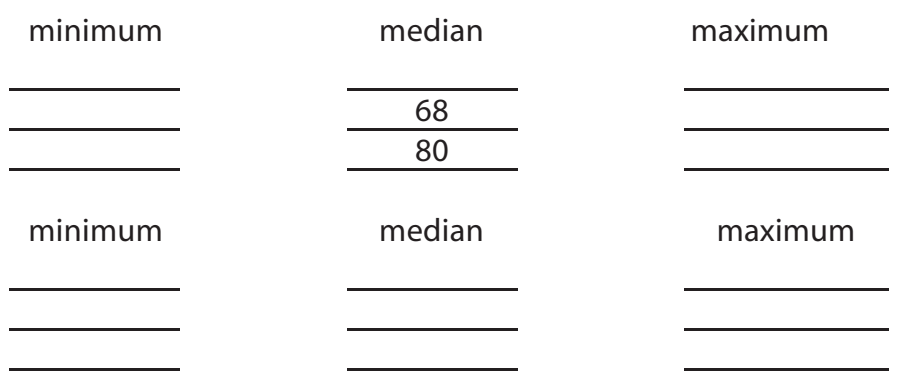

15 areal $\%$ of the total assessment unit

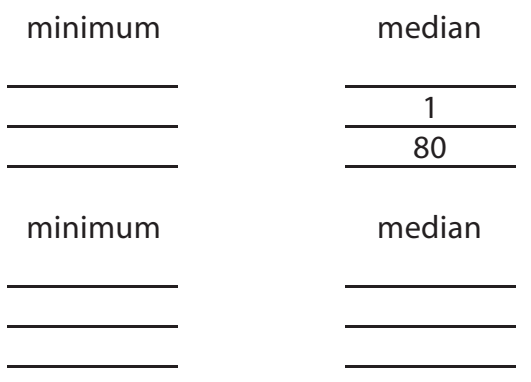

maximum

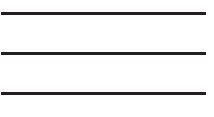

maximum

15 areal \% of the total assessment unit

minimum

median

maximum

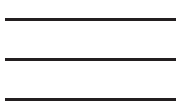

\begin{tabular}{c}
\hline 19 \\
\hline 50 \\
\hline
\end{tabular}

minimum

median

maximum 
5.

represents

16 -

Oil in Oil Fields:

Richness factor (unitless multiplier):.

Volume \% in parcel (areal \% x richness factc

Portion of volume $\%$ that is offshore $(0-100 \%) . . .$. .

Gas in Gas Fields:

Richness factor (unitless multiplier):

Volume $\%$ in parcel (areal $\%$ x richness factor):...

Portion of volume $\%$ that is offshore (0-100\%)......

6. Province 2022

represents

Oil in Oil Fields:

Richness factor (unitless multiplier):

Volume \% in parcel (areal \% x richness factor):...

Portion of volume $\%$ that is offshore (0-100\%).....

Gas in Gas Fields:

Richness factor (unitless multiplier):

Volume $\%$ in parcel (areal $\%$ x richness factor):...

Portion of volume $\%$ that is offshore (0-100\%)......

7. Province 2024

represents

Oil in Oil Fields:

Richness factor (unitless multiplier):

Volume $\%$ in parcel (areal $\%$ x richness factor):...

Portion of volume $\%$ that is offshore $(0-100 \%) . . . .$.

Gas in Gas Fields:

Richness factor (unitless multiplier):................

Volume $\%$ in parcel (areal \% x richness factor):...

Portion of volume $\%$ that is offshore $(0-100 \%) . . . .$.

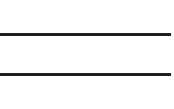

minimum median maximum

\begin{tabular}{ll}
\hline & $\frac{16}{60}$ \\
\hline minimum & \\
\hline & \\
\hline
\end{tabular}

16 areal \% of the total assessment unit

minimum

median

maximum

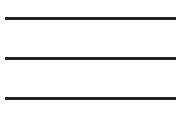

minimum

$\begin{array}{r}\hline 16 \\ \hline 60 \\ \hline\end{array}$

median

maximum

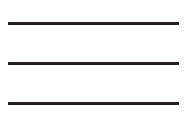

68 areal \% of the total assessment unit

minimum

median

maximum

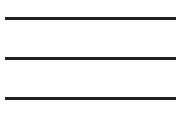

$\begin{array}{r}\hline 68 \\ \hline 85 \\ \hline\end{array}$

minimum

median

maximum 